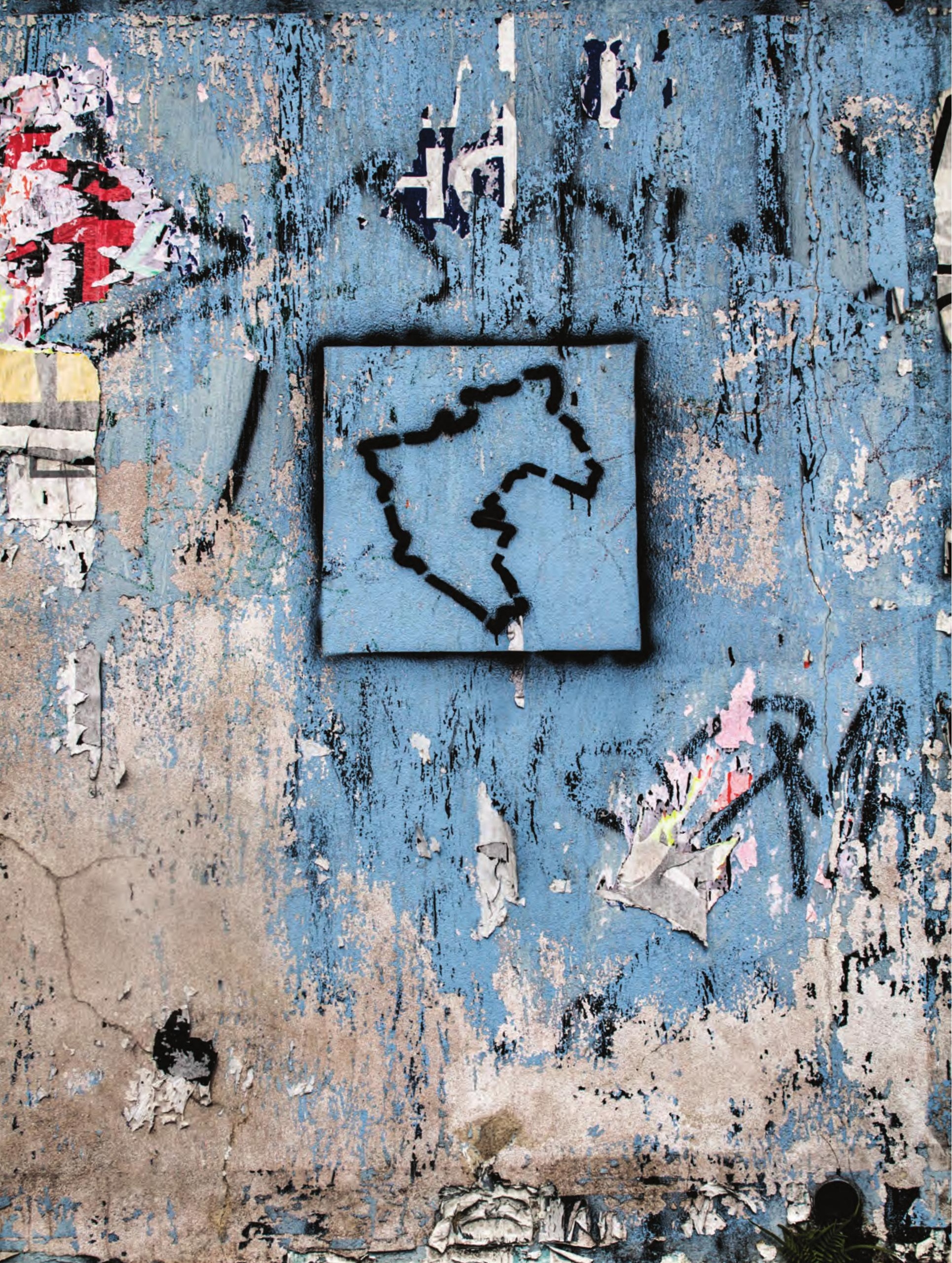




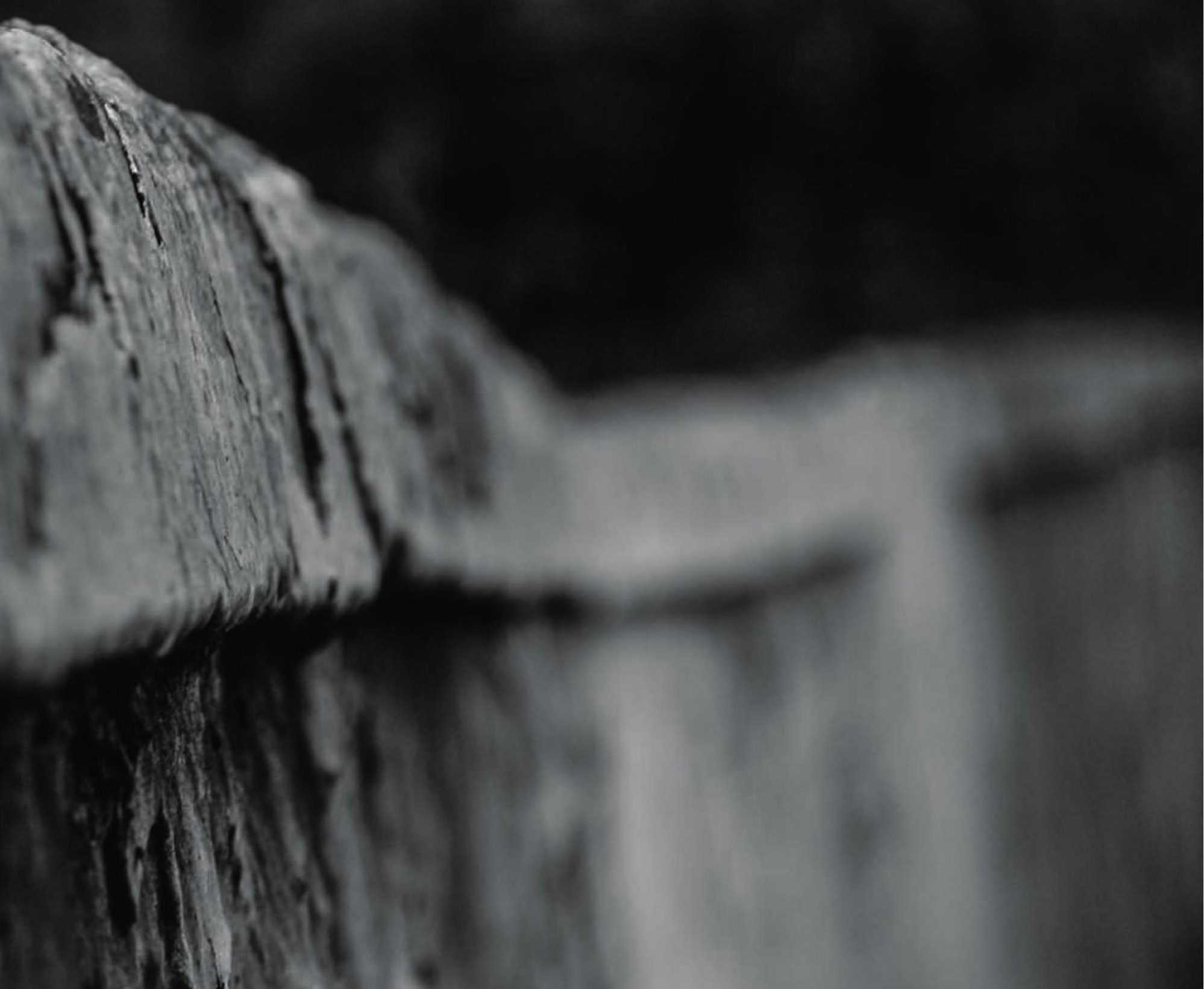




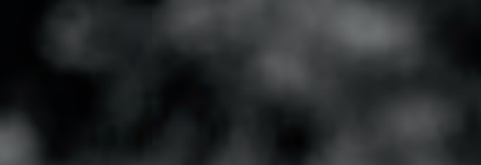

6.7. (3)

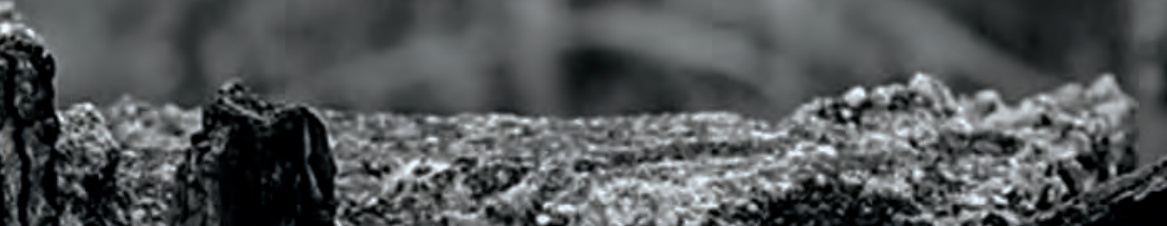
s.

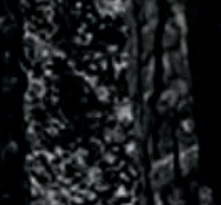

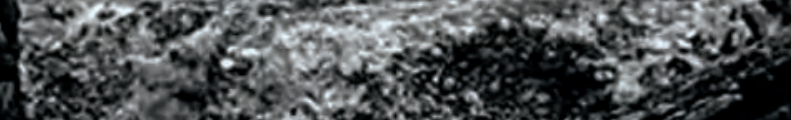

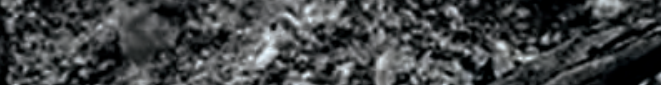
and O v r o

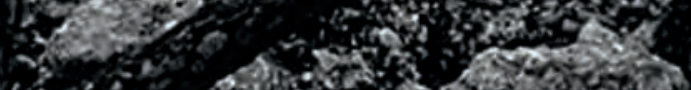
and

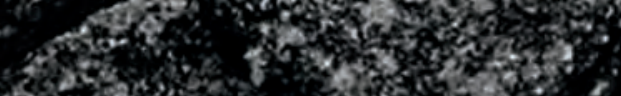
$36 x^{2}$ (1)

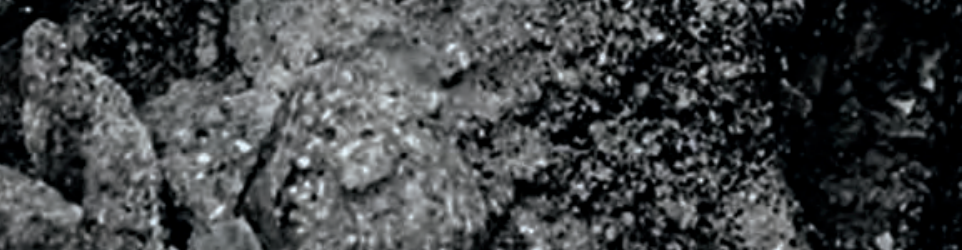
c5 38

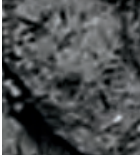

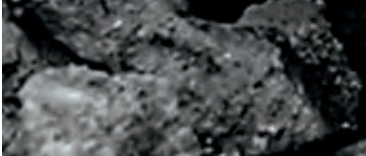


UNIVERSIDADE DE SÃO PAULO

Escola de Comunicações e Artes

Programa de Pós-Graduação em Poéticas Visuais

\section{Paisagem urbana: frestas, fricções e descaminhos}

Alan Beserra Toledo da Silva

Dissertação apresentada ao Programa de Pós-Graduação em Artes Visuais da Escola de Comunicações e Artes da Universidade de São Paulo, para obtenção de título de Mestre em Artes.

Área de Concentração: Poéticas Visuais

Orientadora: Profa. Dra. Branca Coutinho de Oliveira

Versão Original

São Paulo

2018 
Nome: Alan Beserra Toledo da Silva

Título: Paisagem urbana: frestas, fricções e descaminhos

Aprovado em:

\section{Banca Examinadora}

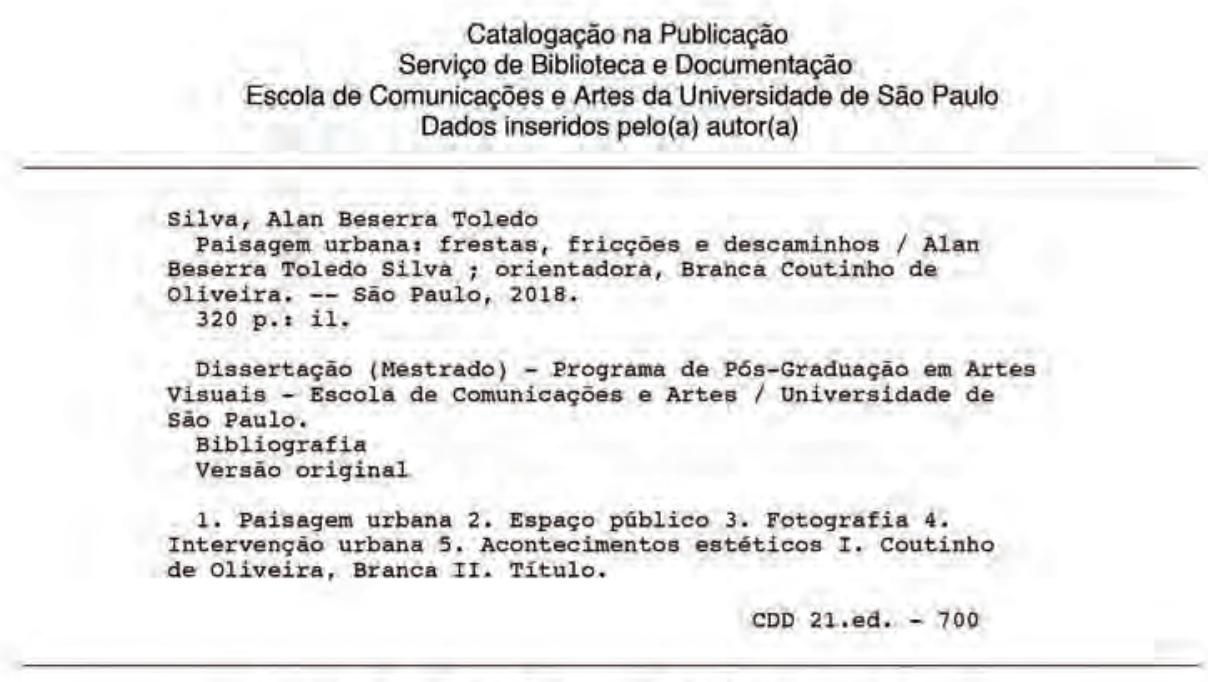

E1aborado por Șarah Lorenzon Ferreira - CRB-8/6888
Prof. Dr.

Instituição:

Julgamento:

Assinatura:

Prof. Dr.:

Instituição:

Julgamento:

Assinatura:

Prof. Dr.

Instituição:

Julgamento:

Assinatura: 


\section{Resumo}

Esta dissertação reflete sobre a criação de um conjunto de operações poéticas realizadas no espaço urbano, cujo intuito é problematizar as influências que o "corpo da cidade" exerce sobre os corpos de seus habitantes e os processos de subjetivação subsequentes. Tem a cartografia como procedimento investigativo-base, que articula a pesquisa em três modos processuais: 1) o caminhar no espaço urbano de maneira errática, com o objetivo de formular e absorver questões que os múltiplos ambientes suscitam; 2) a produção de intervenções artísticas em espaços públicos, com vistas a interpelar locais e transeuntes, desviando-os da rotina prático-funcional através da abertura de "frestas sensíveis" no cotidiano das cidades; 3) produzir deslocamentos das questões do espaço público para espaços privados, por meio de acontecimentos estéticos que utilizam recursos principalmente da fotografia, do vídeo e da performance, para discutir reciprocidades afetivas entre sujeito e paisagem urbana.

Palavras-chave:

1.Paisagem urbana. 2.Espaço público. 3.Fotografia. 4. Intervenção urbana. 5.Acontecimentos estéticos. 


\section{Abstract}

This dissertation reflects on the creation of a set of poetic operations performed in urban space, whose purpose is to problematize the influences that the "body of the city" exerts on the bodies of its inhabitants and the subsequent subjectivation processes. It has the cartography as basic investigative procedure, which articulates research in three procedural modes: 1) walking in urban space in an erratic way, with the objective of formulating and absorbing questions that the multiple environments raise;

2) the production of artistic interventions in public spaces, with a aim of questioning local and passers-by, diverting them from the practical-functional routine by opening "sensitive gaps" in the daily life of the cities; 3 ) to produce shifts from public space issues to private spaces, through aesthetic events, that use resources mainly of photography, video and performance, to discuss affective reciprocities between subject and urban landscape.

Keywords:

1. Urban landscape. 2. Public space. 3. Photography. 4. Urban intervention. 5. Aesthetic events 


\section{Agradecimentos}

Este trabalho foi realizado com o apoio da bolsa CAPES e com a colaboração e generosidade de muitas pessoas. Sou muito grato à Branca de Oliveira, minha orientadora, pela confiança

e companhia ao longo desse trajeto. À Luciana S. Barros, companheira de vida e também minha primeira leitora, sagaz, de apontamentos preciosos. Às professoras Patrícia Moran e Ana Maria Tavares, pelas críticas de meio de percurso. Aos cúmplices Cauê Gruber, Alícia Peres, Bia Falleiros, Dario Vargas, Fábio Menino, Flávio Ferraz, Bruno Vieira, Lucas Lima, Coletivo Àgata, Angélica Del Nery, Andréa D'Amato, Cintia Pimentel, João Leoci, Felipe F. Neves e Coletivo Autônomo Temporário, por estarem juntos em momentos determinantes. À Oficina Cultural Oswald de Andrade e ao Programa Mergulho Artístico, que através de uma bolsa possibilitou-me desenvolver o trabalho Fragmentos. Ao Centro Cultural Inamar (em especial à Mardilene), que abriram o laboratório por meses para minhas experimentações. À Lívia Aquino, Ronaldo Entler, Pio Figueroa e Carol Lopes, pelos ótimos comentários e provocações nos tempos do MIS, e ao meu porto seguro: Benedita, Manuel e Aline. 
"O desafio consistiria em livrar-se do pseudo-movimento que nos faz permanecer no mesmo lugar, e sondar que tipo de meio uma cidade ainda pode vir a ser, que afetos ela favorece ou bloqueia, que trajetos ela produz ou captura, que devires ela libera ou sufoca, que forças ela aglutina ou esparze, que acontecimentos ela engendra, que potências fremem nela e à espera de quais novos agenciamentos. É nesses termos que se deveria ler 0 desafio de pensar uma cidade subjetiva, que nada tem a ver com uma utopia urbana..."

Peter Pál Pelbart (em A vertigem por um fio) 


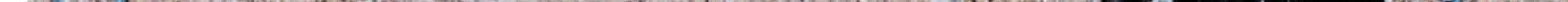




$$
\begin{aligned}
& \text { SUMÁRIO } \\
& \text { INTRODUCÃO } \\
& \text { ARTE COMO MÉRINA } \\
& \text { I.PREMISSAS POEETICAS FTÁTICAS DE GUERRA } \\
& 1.2 \text { OO ENGENDRAMENTO DO }
\end{aligned}
$$

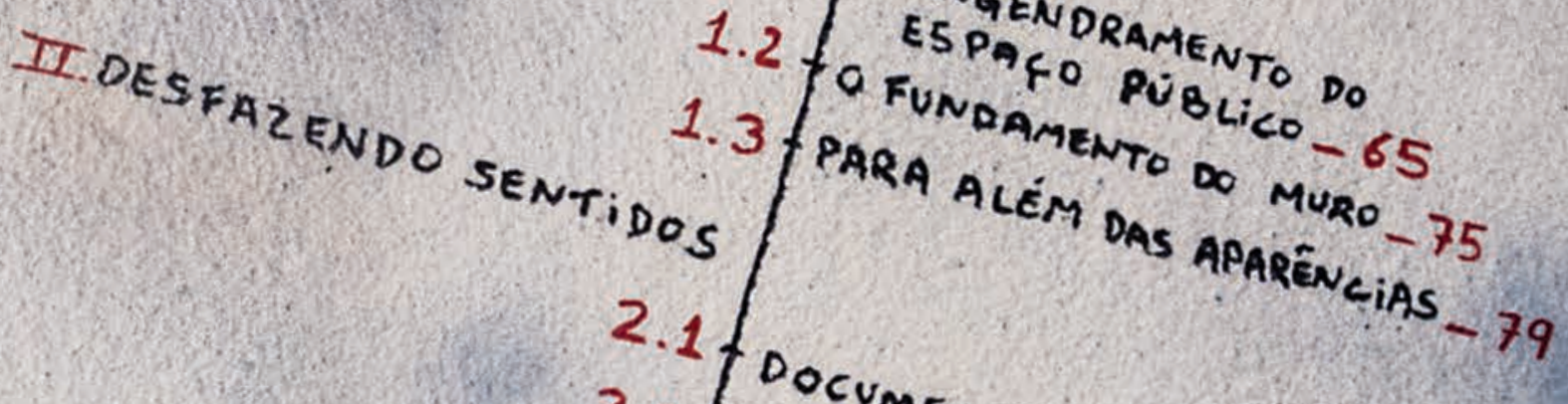

$$
\begin{aligned}
& \text { III.PERC }
\end{aligned}
$$

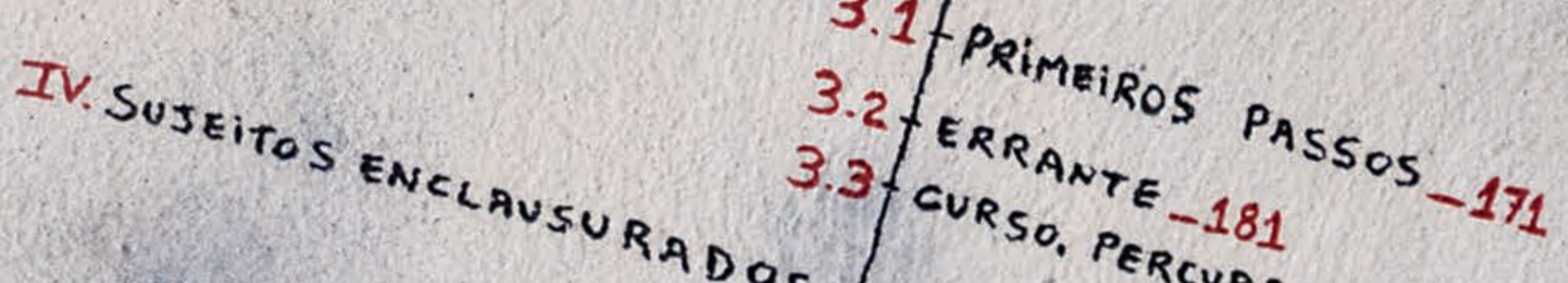

$$
\begin{aligned}
& 4.1 \text {. Discursos }-2 \mathrm{O}_{2} \\
& 4.2 \text { MAQQUINAS DE SUNTOR SETIVACFAO-259 }
\end{aligned}
$$

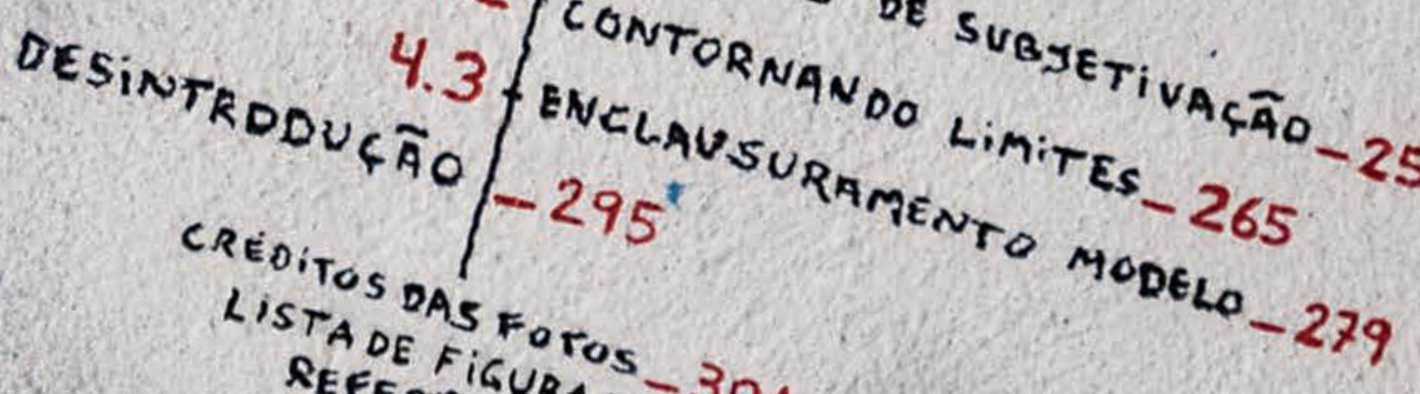

$$
\begin{aligned}
& \begin{array}{l}
\text { LISTA DAS FOTOS } \\
\text { REFEREGURAS } 301 \\
\text { OAEN }
\end{array} \\
& \begin{array}{l}
\text { AP } N_{D i C E}-303 \\
\text { APR }-309
\end{array}
\end{aligned}
$$




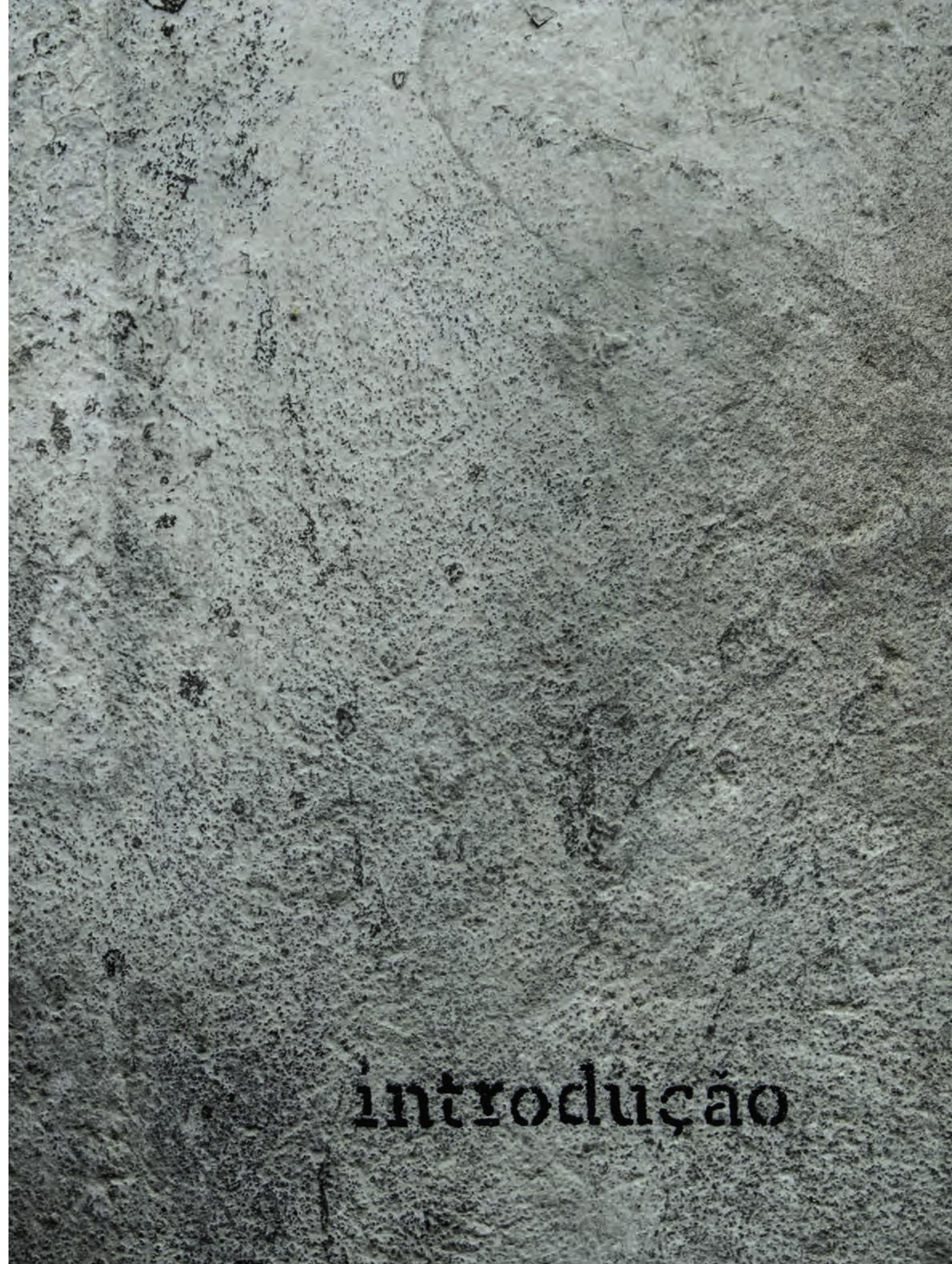




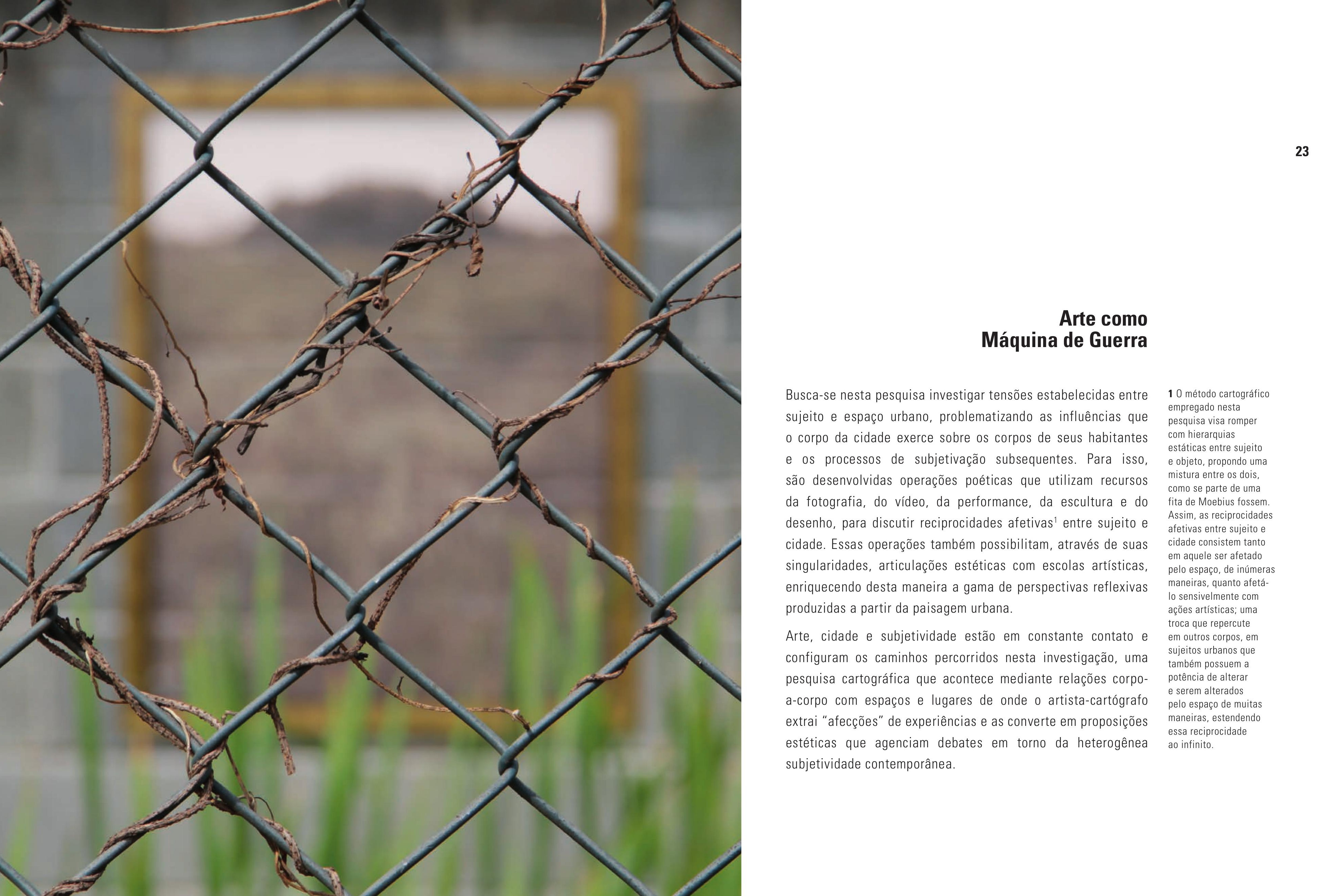


A pesquisa articula-se em três modos processuais que se desdobram em experimentos poéticos: o primeiro modo poético é o caminhar no espaço urbano de maneira errática, cujo intuito é observar e absorver questões que os múltiplos espaços suscitam; o segundo, corresponde à produção de intervenções 2 "Tudo o que é artísticas em espaços públicos, que visam interpelar espaços

subjetivação e transeuntes, desviando-os da rotina prático-funcional do capitalística - tudo o que nos chega pela linguagem, pela família

pelos equipamentos

coletivos que nos

rodeiam - não é apenas

uma questão de

ideia, não é apenas

uma transmissão de

eio de enunciados

significantes. Tampouco

se reduz a modelos
de identidade, ou a

dentificações com pólos

maternos, paternos, etc.

Trata-se de sistemas

de conexão direta entre

as grandes máquinas

produtivas, as grandes

máquinas de controle

social e as instâncias

psíquicas que definem

a maneira de perceber

o mundo." (GUATTARI;

ROLNIK, 1986, p. 26)

3 Quando me refiro à

da potência", estou

utilizando conceitos

de Espinosa, de que

a essência de todo

ser é a afirmação

de sua potência em

constante expansão

e diferenciacãão

(ESPINOSA, 2015, p. 251) cotidiano das cidades através de desestabilizações sensíveis;

or fim, o terceiro modo poético realiza-se com deslocamentos

de questões do espaço público para espaços privados, por meio

de trabalhos artísticos produzidos a partir das fases anteriores

constituindo assim uma pesquisa composta em diversas camadas

de operações poéticas que promovem reflexões sobre a relação

do sujeito com o espaço urbano.

Cidades são máquinas de sentido que nos atravessam e nos moldam cotidianamente. A cada passo, a cada esquina, somos subjetivados ${ }^{2}$ pelo espaço. Assim, pensar e produzir sobre o espaço de forma crítica se torna uma operação crucial diante das uniformizações que o contexto social impõe aos sujeitos no ambiente urbano, onde desejos e atitudes são conformados a todo instante por ideologias hegemônicas que alteram também a potência intrínseca do espaço público como lugar de identificação, interação e apropriação por seus habitantes.

Em relação a esse espaço que não coincide com a sua potência, os filósofos Gilles Deleuze e Félix Guattari a ele se referem como um espaço estriado, conceito que corresponde ao espaço controlado, em que o território é repartido segundo determinações racionalistas que resultam em um menor grau de diferenciação de sua potência ${ }^{3}$, ou seja, em menores possibilidades de acontecimentos. Em contraposição, os autores também apresentam o conceito de espaço liso, de natureza distinta, cuja potência de desconstruir estabilidades e diferenciar-se acontece em devir, produzindo desterritorializações que propiciam novos saberes e percepções. Contudo, cabe frisar que ambas noções são vivas e cambiantes, sendo possível a criação de "alisamentos" em espaços estriados, assim como o contrário também é possível, com forças "estriantes" que almejam aumentar seus domínios.

Ao trazer estes conceitos para o âmbito artístico, notamos que a arte também carece de espaço liso para efetivar agenciamentos e produzir novos universos significantes e fluxos desterritorializantes. Sendo assim, compreendemos a arte como uma máquina de guerra, pois atua de modo autopoiético dando consistência às sensações que produz.

Se os nômades criaram a máquina de guerra, foi porque inventaram a velocidade absoluta, como "sinônimo" de velocidade. E cada vez há uma operação contra o Estado, indisciplina, motim, guerrilha ou revolução enquanto ato, dir-se-ia que uma máquina de guerra ressuscita, que um novo potencial nomádico aparece, com a reconstituição de um espaço liso ou de uma maneira de estar no espaço como se fosse liso (Virilio recorda a importância do tema sedicioso ou revolucionário "ocupar a rua"). É nesse sentido que a réplica do Estado consiste em estriar o espaço, contra tudo o que ameaça transbordá-lo. (DELEUZE; GUATTARI, 1997, p. 64)

A máquina de guerra é produtora de linhas de fugas que exploram o espaço liso para além do Estado e das hierarquias, efetivando a constante exploração de sua potência. Ao contrário do que a simples associação de palavras pode dar a entender, a máquina 
de guerra não necessariamente tem a batalha como objetivo,

mas a criação de espaço liso, a ocupação e o deslocamento nesse espaço, sendo estes os fatores que constituem seu objetivo positivo. Em movimento, a máquina de guerra inevitavelmente colide com forças "estriantes" que competem com seu objetivo positivo e, nessas ocasiões, a máquina de guerra, por meio de procedimentos de guerrilha, entra em conflito com forças que visam coibi-la. Assim, a máquina de guerra atua de modo ético, defendendo a vida diante das ameaças de impotência que a põe em risco. Seguindo a concepção do filósofo Espinosa, podemos dizer também que a máquina de guerra luta por liberdade, uma vez que liberdade é entendida como a capacidade do ser de corresponder a sua essência - de expandir ao máximo o seu grau de potência.

Experimentar materiais, desconstruir signos, preencher o espaço público com intervenções sensíveis, criar afetos, composições de corpos e fazer do próprio cotidiano uma experiência estética que desencadeia fluxos e linhas de fuga, são estas algumas das possibilidades infinitas que a arte no ambiente urbano pode efetivar. Para isso, é necessário estar atento e em perpétuo embate contra o "estriamento", pois a própria máquina de guerra pode ser capturada e transformada também em mais um mecanismo de assujeitamento como tanto outros em que a concepção produtivista da vida investe.

Michel de Certeau apresenta uma diferenciação entre tática e estratégia que podemos relacionar ao conceito de espaço liso e espaço estriado. Para Certeau, a estratégia visa criar sempre espaços abstratos, construídos segundo imperativos técnicos, por meio de mapeamentos e de imposições planificadas para os lugares; enquanto as táticas, produzem operações no nível da utilização direta do espaço pelo sujeito comum, capaz de alterá-lo e manipulá-lo através de práticas de "alisamento" dos espaços que a estratégia visa "estriar".

Uma distinção entre estratégias e táticas parece apresentar um esquema inicial mais adequado. Chamo de estratégia o cálculo (ou a manipulação) das relações de forças que se torna possíve a partir do momento em que o sujeito de querer e poder (uma empresa, um exército, uma cidade, uma instituição científical pode ser isolado. A estratégia postula um lugar suscetível de ser circunscrito como algo próprio e ser a base de onde se podem gerir as relações com uma exterioridade de alvos e ameaças los clientes ou concorrentes, os inimigos, o campo em torno da cidade, os objetivos e objetos da pesquisa etc.).

(...)

A tática não tem por lugar senão o do outro. E por isso deve joga com o terreno que lhe é imposto tal como 0 organiza a lei de uma força estranha. Não tem meios para se manter em si mesma, à distância, numa posição recuada, de previsão e de convocação própria: a tática é movimento "dentro do campo de visão do inimigo", como dizia Von Bullow, e no espaço por ele controlado. Ela não tem, portanto, a possibilidade de dar a si mesma um projeto global nem de totalizar o adversário num espaço distinto, visível e objetivável. Ela opera golpe por golpe, lance por lance. (CERTEAU, 2014, p. 93 e 95) 
E é desta maneira que esta pesquisa pretende realizar-se, por meio de táticas afetivas, "golpes" sensíveis no âmbito urbano que configuram a cartografia de fricções entre sujeito e espaço urbano. Tal tática acontece em fluxo turbilhonar, por encontros de corpos, afetos ${ }^{4}$, paisagens, histórias e situações. Através de experiências no "campo de visão do inimigo", onde o próprio corpo do artista é utilizado para captar tensões e construir proposições poéticas. Acerca desse processo, Laura Pozzana diz que "subjetividades e objetividades se fazem a partir dos diferentes ritmos, interesses, percepções e materialidades presentes. 0 cartógrafo se faz por um regime de afetabilidade, ele toca e é tocado" (POZZANA, 2013, p. 334).

Em meio à reciprocidade de afetos no espaço urbano, esta pesquisa pretende perceber tensões e criar blocos de sensações a partir delas, diferenciando-se do conceito clássico de cartografia, propondo algo mais sutil, ao observar processos de subjetivação ao invés de reproduzir cartas topográficas. Suely Rolnik nos brinda com a seguinte "definição provisória" para cartografia que coincide com os caminhos desta pesquisa:

Para os geógrafos, a cartografia - diferentemente do mapa: representação de um todo estático - é um desenho que acompanh e se faz ao mesmo tempo que os movimentos de transformação da paisagem. Paisagens psicossociais também são cartografáveis. A cartografia, nesse caso, acompanha e se faz ao mesmo tempo que o desmanchamento de certos mundos - sua perda de sentido - e a formação de outros: mundos que se criam para expressar afetos contemporâneos, em relação aos quais os universos vigentes tornaram-se obsoletos.

Sendo tarefa do cartógrafo dar língua para os afetos que pedem passagem, dele se espera basicamente que esteja mergulhado nas intensidades de seu tempo e que, atento às linguagens que encontra, devore as que the parecerem elementos possíveis para a composição das cartográficas que se fazem necessárias. cartógrafo é, antes de tudo, um antropófago. (ROLNIK, 2011, p. 23)

Assim, narrativas cartográficas são produzidas através de experimentos poéticos nesta pesquisa "antropofágica" urbana conforme a "tarefa" do cartógrafo proposta por Rolnik. Vale ressaltar também que ao longo dos percursos desta investigação os próprios processos cartográficos são revistos e repensados de acordo com cada fase da pesquisa, cujo cuidado se fe para que a própria cartografia não fosse convertida em uma metodologia estriada ${ }^{5}$. Os três níveis das táticas empregadas (o caminhar como prática estética, as intervenções no espaço público e o deslocamento de problemas e objetos das ruas para espaços privados) configuram-se como meios para problematiza as influências que o espaço urbano exerce sobre os sujeitos, dando visibilidade às fricções por meio visualidades poéticas.
5 Em relação a esta questão, Deleuze que: "Um 'método' que: "Um metodo" é o espaço estriado do cogitatio universalis, e traça um caminho que deve ser seguido de un ponto a outro. Mas a situa o pensamento situa o pensamento num espaço liso que poder medi-lo e para 0 qual não há método possivel, reproducão possivel, reproduça

somente revezamentos, O penezzi, celances. o Vampiro, não tem o Vampiro, não tem inagem, nem para para fazer cópia. № para lazo. a flecha já não vai de um ponto a outro. mas será recolhida num ponto qualquer.

para ser relancada a um ponto qualquer, tonde a permutar com 0 atirador e 0 alvo 0 problema da máquin de guerra é o dos revezamentos, mesmo com parcos percursos. e não o problema arquitetônico do model ou do monumento. Um povo ambulante de revezadores, em lugar de uma cidade modelo. (DELEUZE; GUATTARI. 1997, p. 49-50) 
Fricções

As fricções que dão nome à pesquisa não somente correspondem às relações entre sujeito e espaço urbano e as múltiplas afecções decorrentes das composições entre corpos. A ideia de fricções também atravessa todo o modo como esta pesquisa está organizada, e aparece em todos os capítulos de maneiras variadas, seja nos modos dos sujeitos de relacionar-se com o espaço público em formas heterorreguladas, seja também nos atritos de conceitos e linguagens que se justapõem nas operações poéticas empreendidas.

Assim, a organização desta pesquisa gira em torno de dois eixos centrais, que correspondem aos modos de produção poéticos e dividem a dissertação em duas partes: a primeira, com as intervenções urbanas, nos capítulos "Premissas Poéticas" e "Desfazendo Sentidos"; e a segunda, com o caminhar como prática estética, nos capítulos "Percursos Urbanos" e "Sujeitos Enclausurados". Por conta dessa escolha organizacional, os trabalhos poéticos apresentados não estão dispostos de maneira cronológica, e sim de acordo com afinidades que correspondem aos desdobramentos de questões e experimentações poéticas que configuram os percursos da pesquisa. Vale ressaltar também aqui que o recorte de trabalhos apresentados corresponde aos últimos quatro anos de produção, iniciando-se em 2014, com Janelas, e vindo até os trabalhos realizados neste ano de 2018, além também de alguns esboços embrionários de projetos ainda não concluídos, que demonstram a pesquisa em devir.

No primeiro capítulo, "Premissas Poéticas", apresentam-se questões fundantes da esfera pública e da esfera privada a partir da gênese dos conceitos na Grécia Antiga, em que a partir da comparação com a atualidade, nota-se distorções dos empregos dos conceitos nas cidades contemporâneas. Nesse capítulo as noções de público e privado também se encontram friccionadas, o que é explicitado com as operações poéticas da série Janelas, na qual problematizam-se os muros no espaço urbano que além de segregar espaços, também interrompem horizontes na paisagem urbana. Em "Premissas Poéticas" outras discussões também são propostas a partir das operações poéticas de Janelas, como o site specific, a fotografia e a utilização das molduras na rua, entre outras.

No capítulo seguinte, "Desfazendo Sentidos", o recorte das intervenções urbanas permanece com os trabalhos Paisagens Esculpida I e Paisagem Esculpida II, expandindo a discussão do problema dos muros nas cidades assim como o tema das molduras na tradição pictórica da arte. No entanto, a fricção central desse capítulo se refere às definições cristalizadas de linguagens artísticas, que é problematizada através de operações poéticas que habitam espaços entre a performance, a escultura e o registro em fotografia e vídeo. Em "Desfazendo Sentidos" discute-se também as noções conceituais de espaço e paisagem, iluminando assim ideias-chave dessa pesquisa.

0 terceiro capítulo, "Percursos Urbanos", inaugura a segunda parte da pesquisa, que corresponde ao caminhar com prática poética. Nessa etapa as fricções são evidenciadas a partir de relações diretas entre sujeitos e espaço urbano dadas por formas distintas de deslocamentos pedestre no espaço público, onde o modo prático-funcional é substituído por experiências erráticas. Em "Percursos Urbanos", apresentam-se um corpo de trabalhos poéticos de períodos espaçados - Fragmentos, Oju Vitruviano e 
Nuncat, cujas operações poéticas, apesar de terem o caminhar como operação poética base, distinguem-se em formas e em materialidades empregadas. Nesse capítulo também é feita uma regressão histórica que busca apresentar experiências antecessoras do caminhar nas cidades como prática estética com as vanguardas dadaístas, surrealistas e o movimento da Internacional Situacionista.

0 quarto capítulo, intitulado "Sujeitos Enclausurados", discorre sobre como o espaço urbano produz sujeitos através de processos de subjetivação. Tema que é abordado no capítulo a partir dos trabalhos Enclaves Fortificados e Cidade Linda. Nesse último capítulo, as fricções são explicitadas em segregações espaciais e sociais ocasionadas pelo viés da "lógica dos condomínios". De certa maneira, esse capítulo carrega em si todas as questões dos capítulos anteriores, como a questão do público e do privado, dos muros, do caminhar como operação poética, assim como o problema central da pesquisa, que concerne em como o espaço urbano exerce influências sobre sujeitos efetuando processos de subjetivação.

Vista de um modo geral, a pesquisa configura-se como uma cartografia não apenas por conta de sua metodologia - tessitura de relações corpo-a-corpo com o espaço urbano -, mas também porque registra fluxos e áreas de intensidades nas operações poéticas, assim como questões conceituais que atravessam os trabalhos e suas singularidades. Por fim, esta apresentação de pesquisa, em forma de dissertação acadêmica, tenta abarcar 0 panorama de uma pesquisa em movimento.

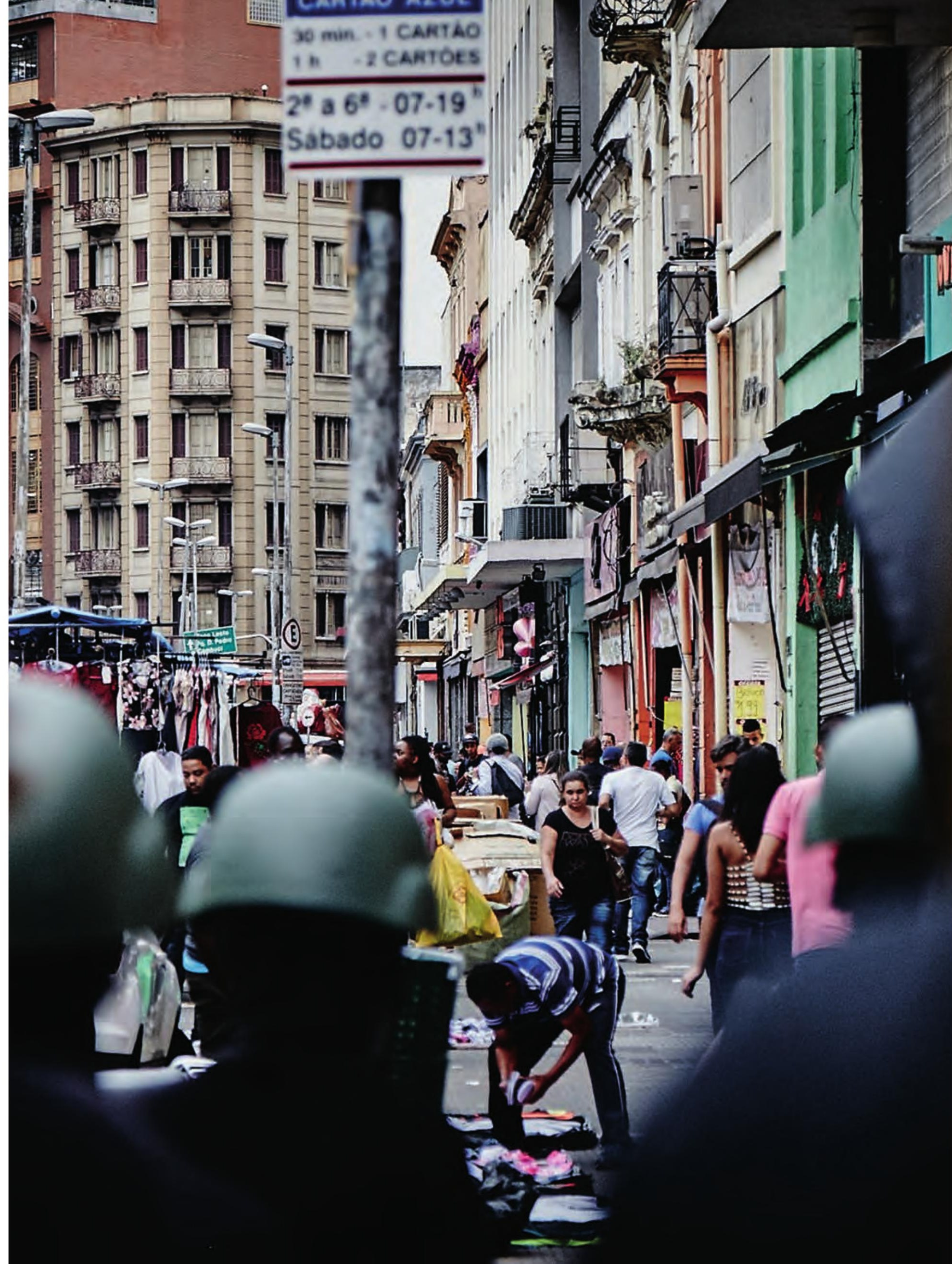




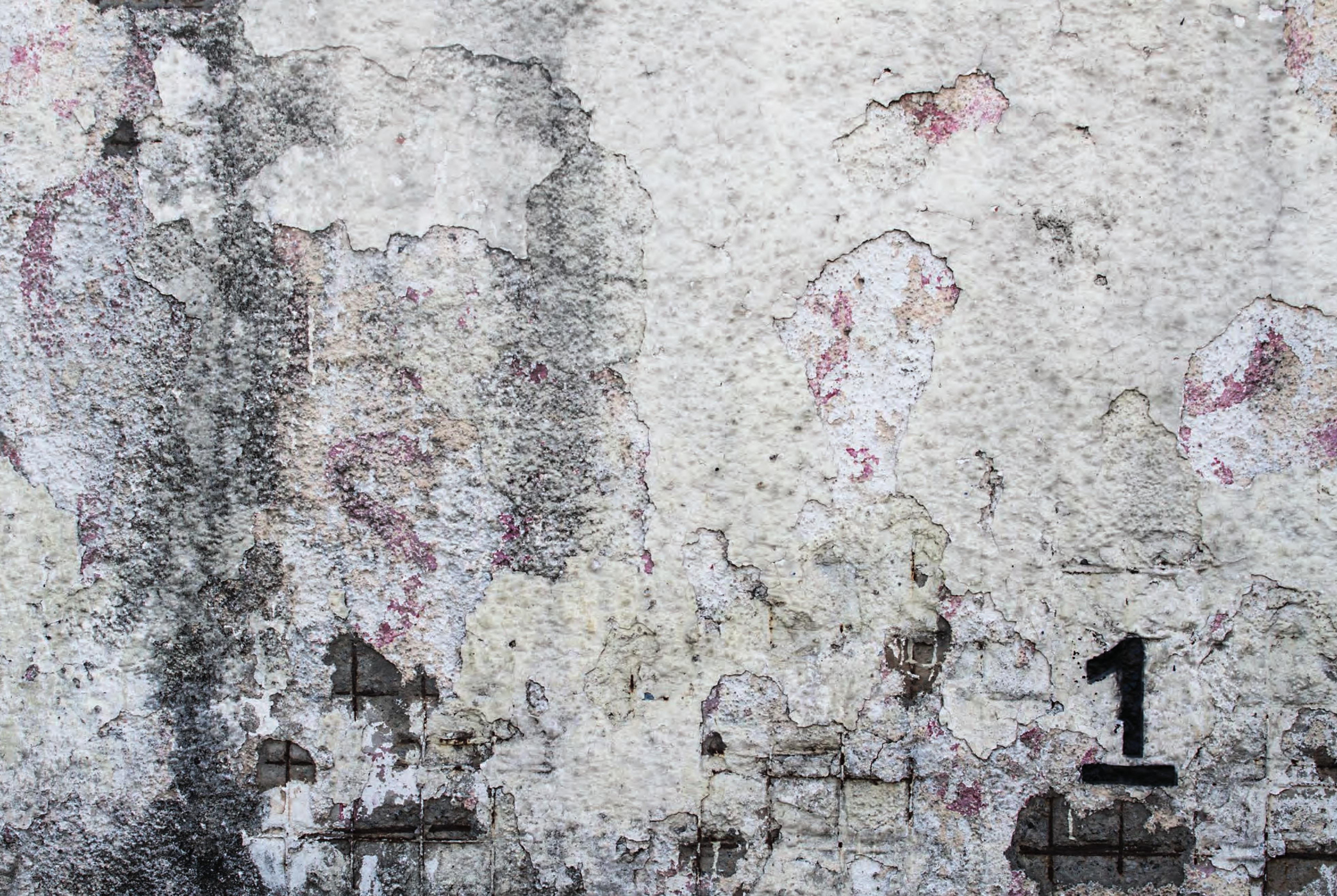


t.t4 ares?

(20.7. 4. 4

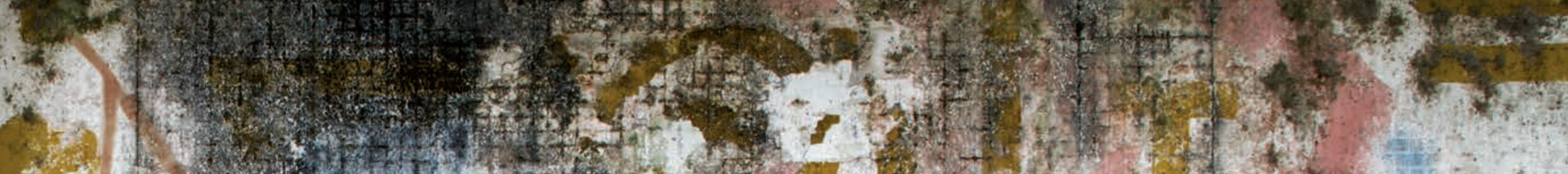

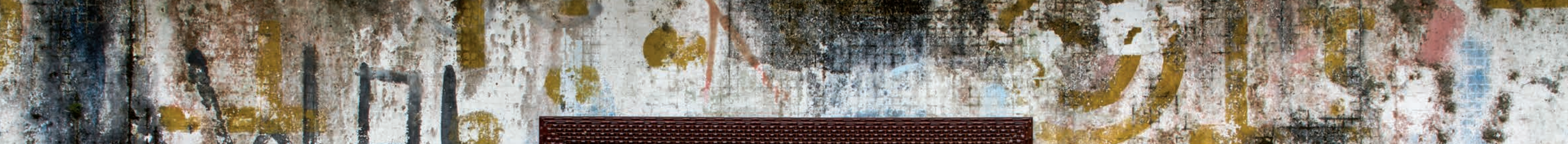

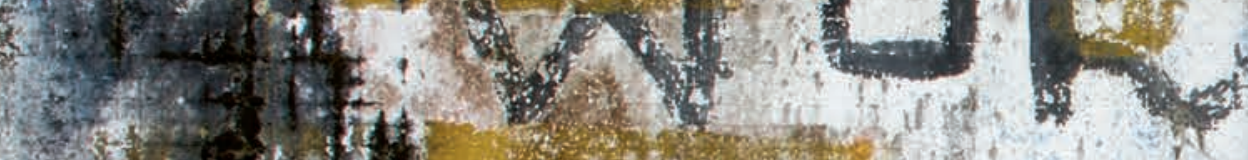

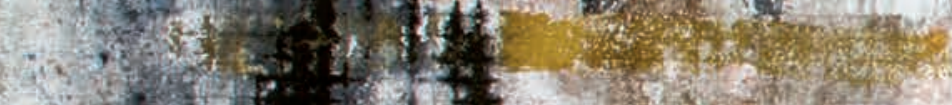
$-4.7+4.2502$

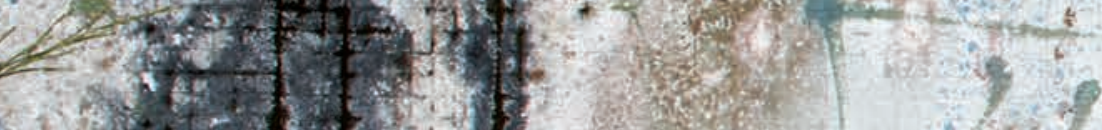

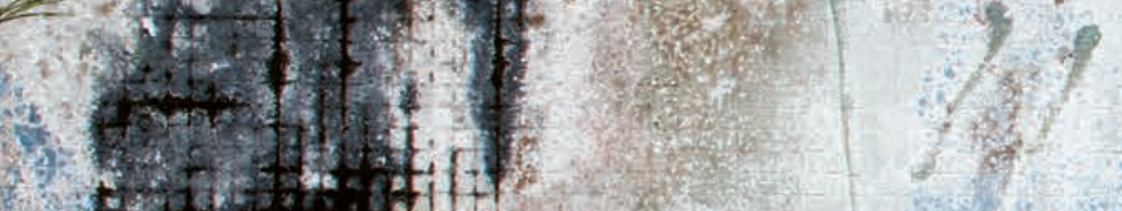
Hitheng +2 tor

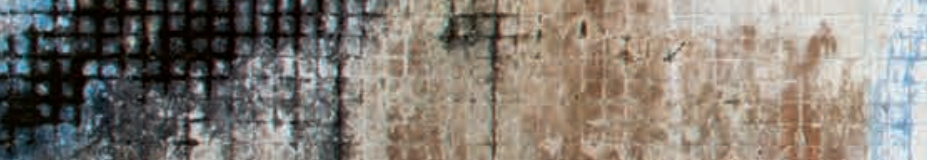

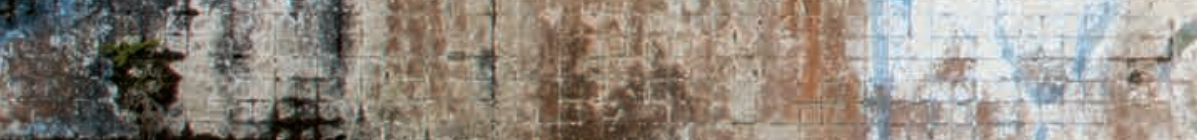

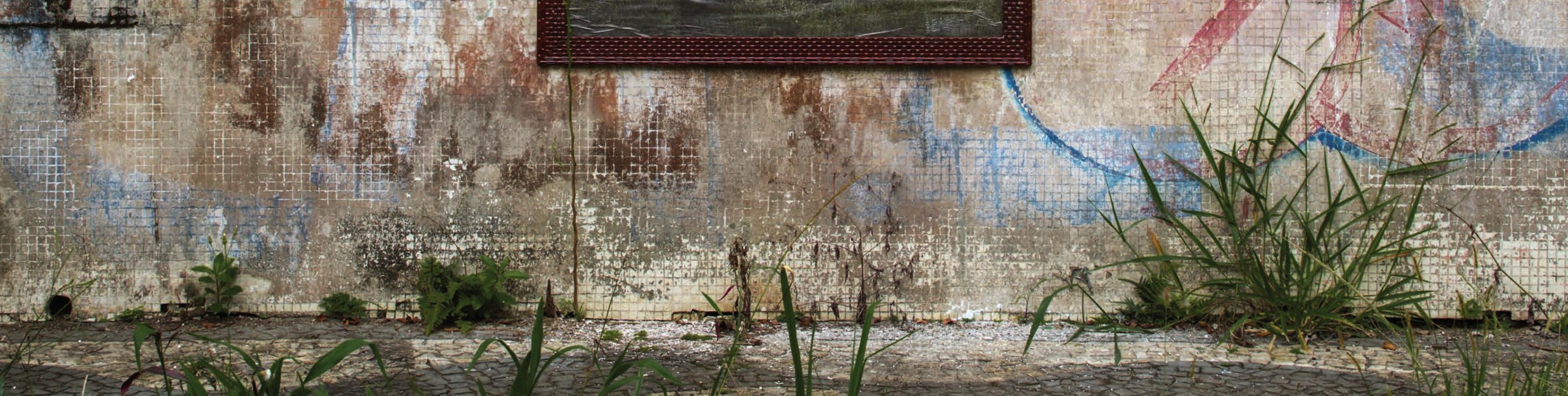

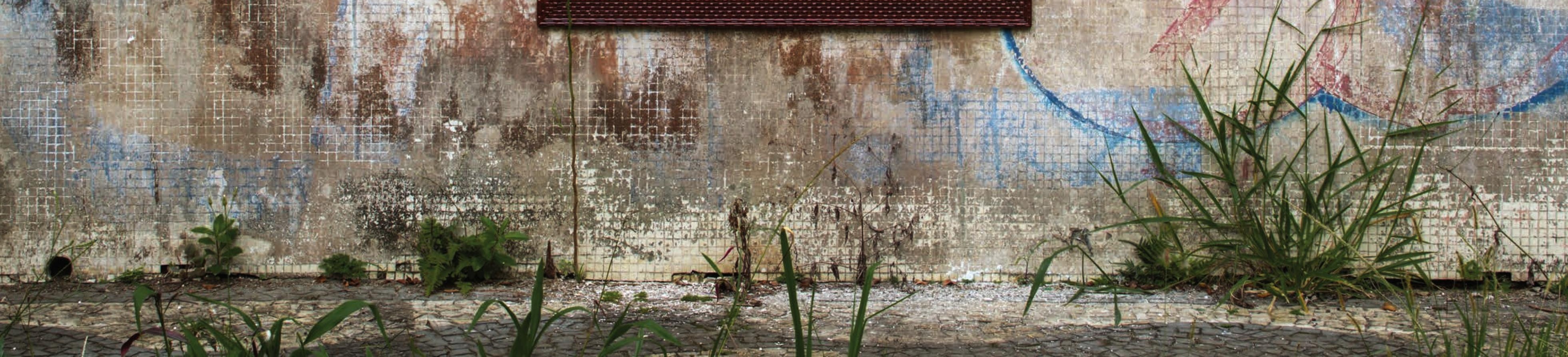




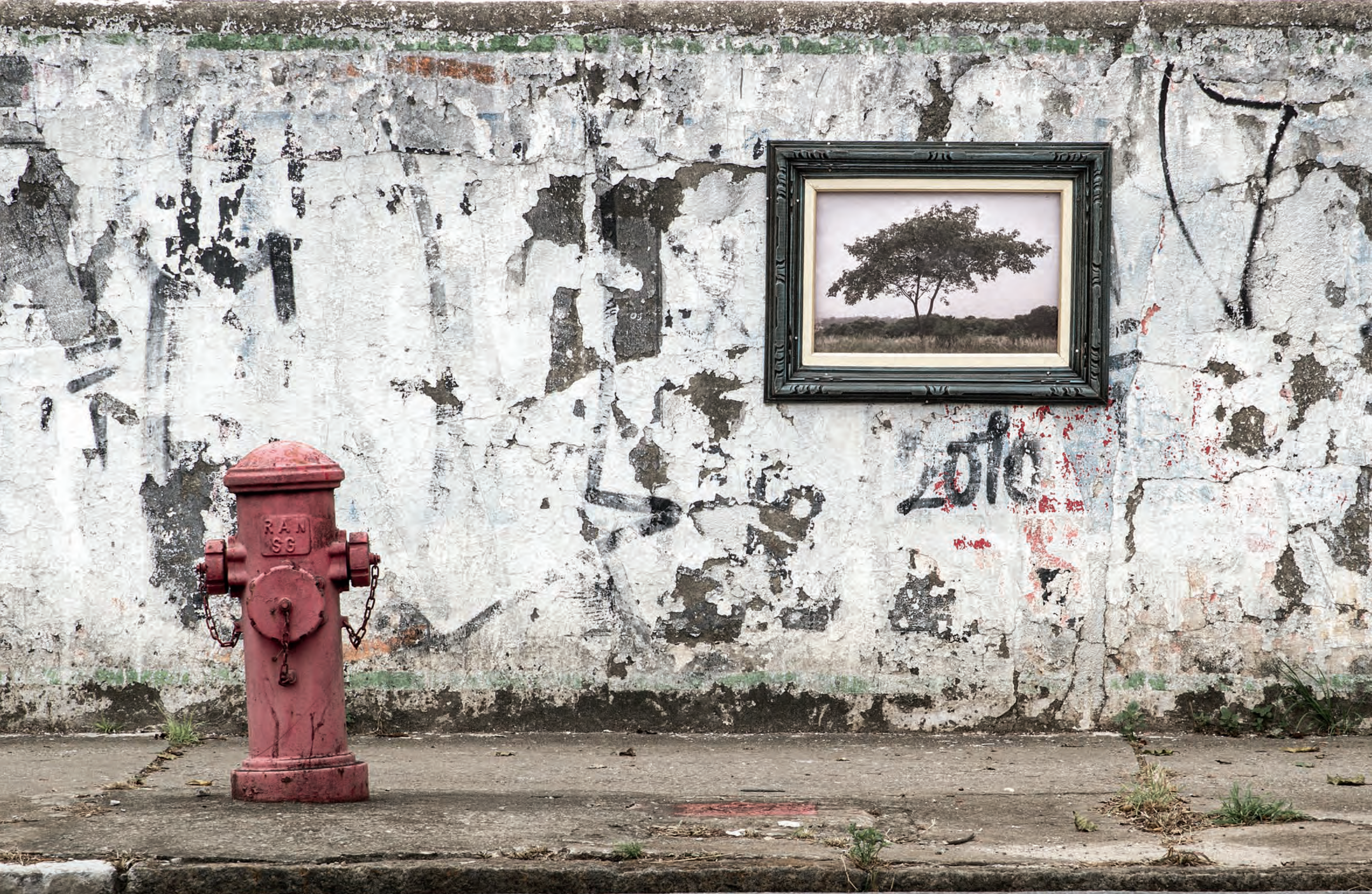




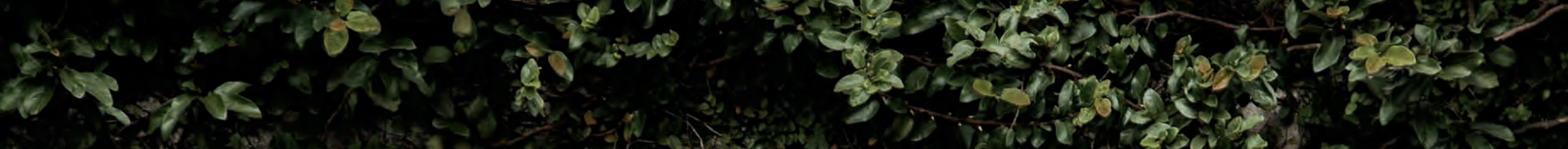

5

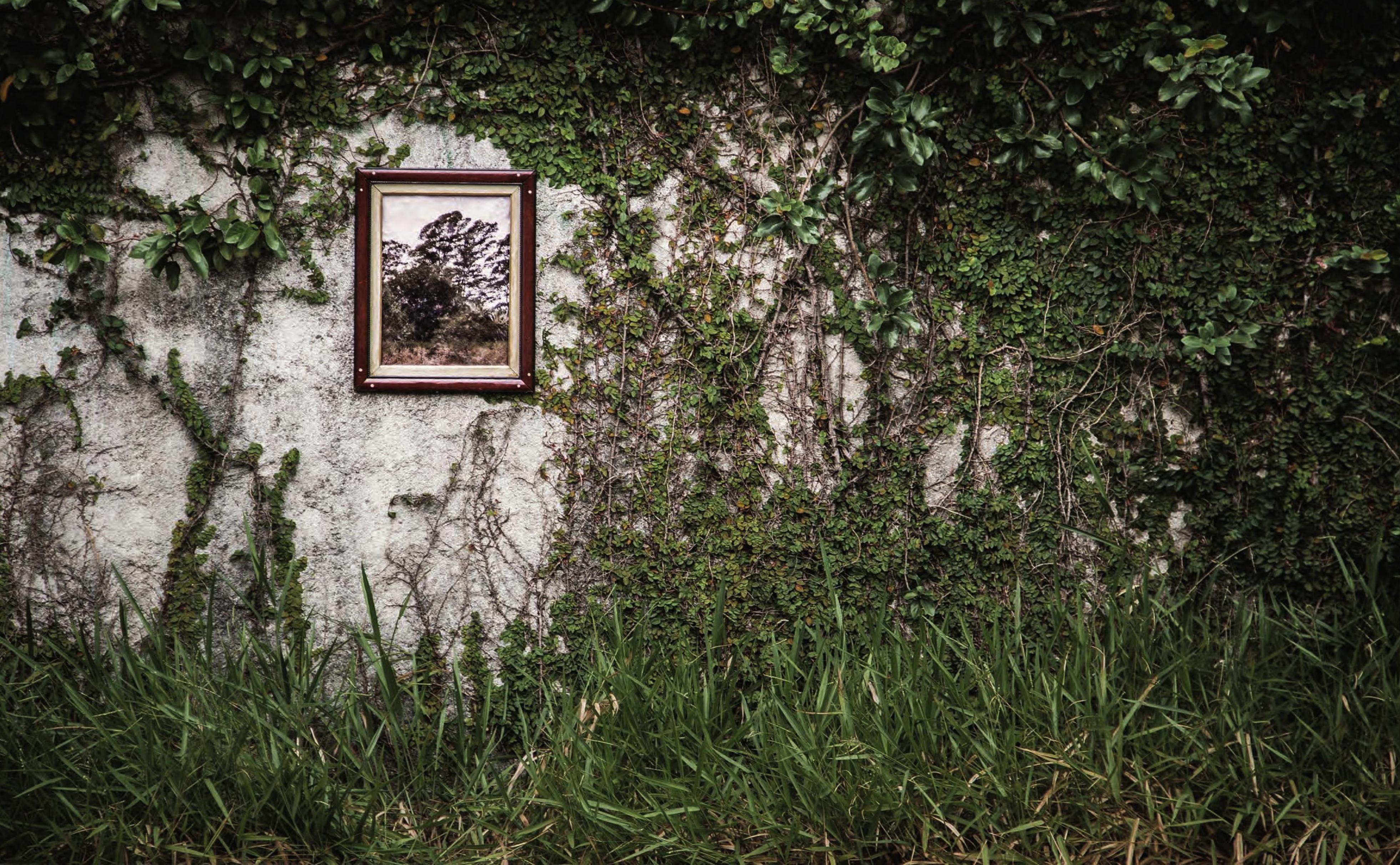




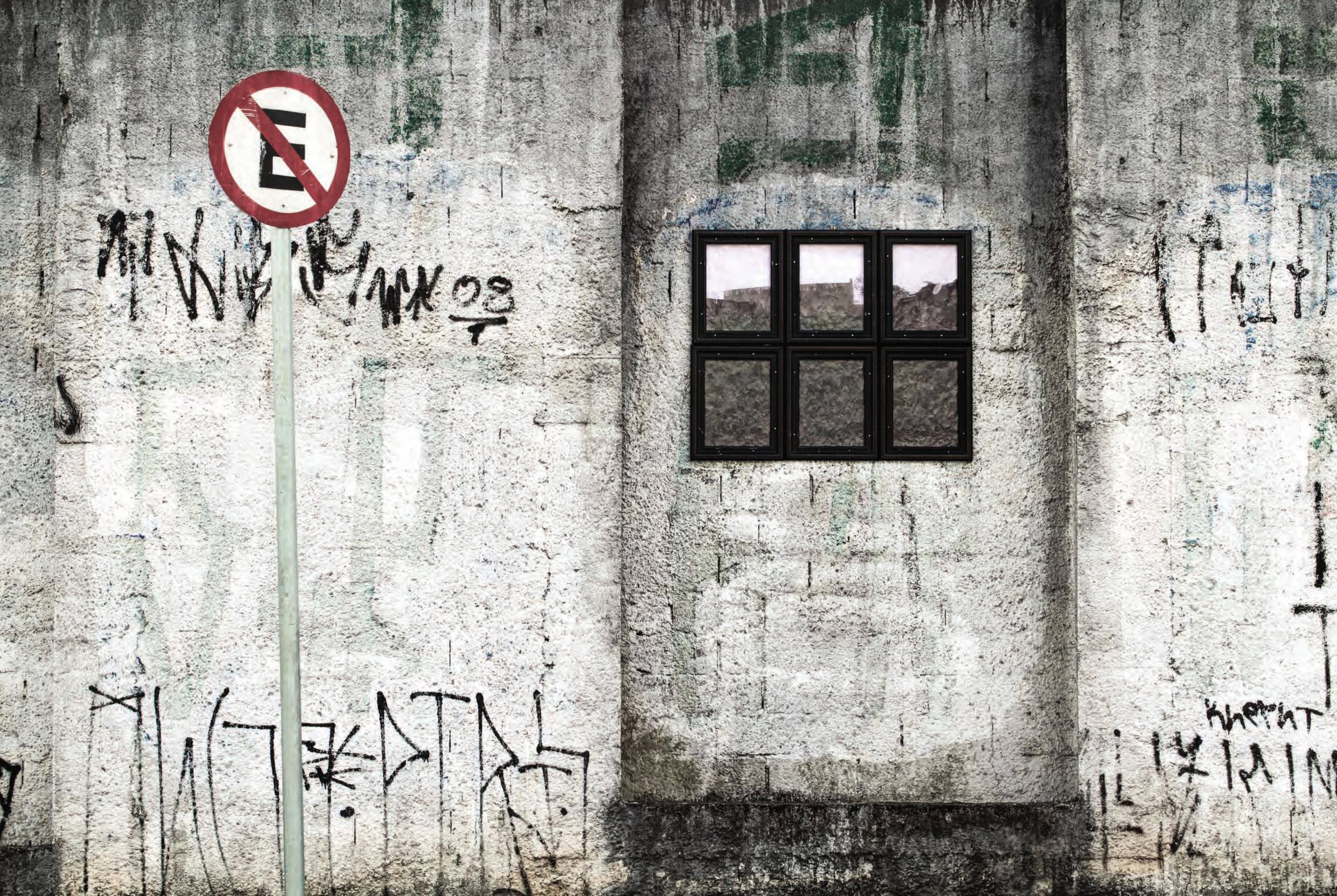




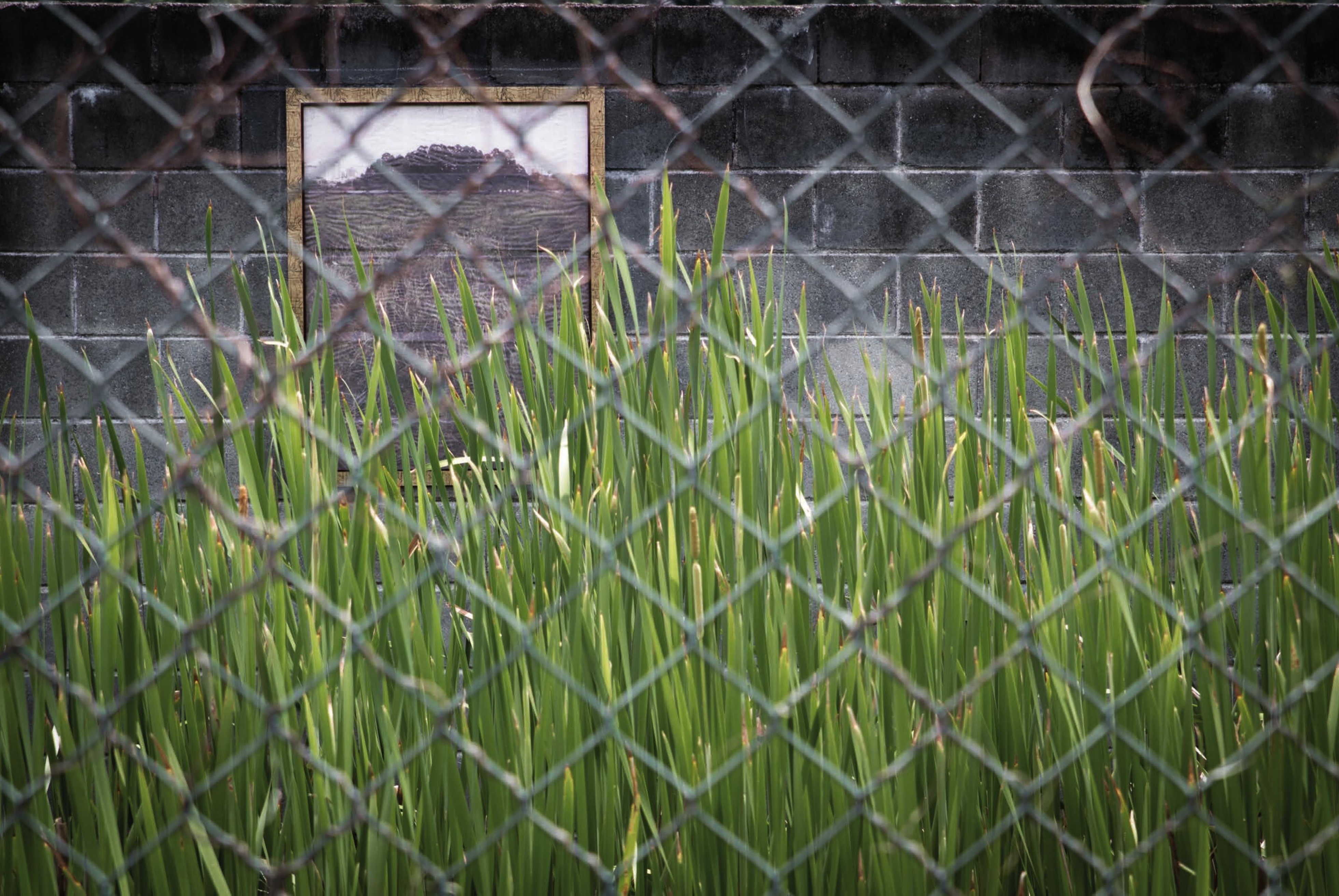




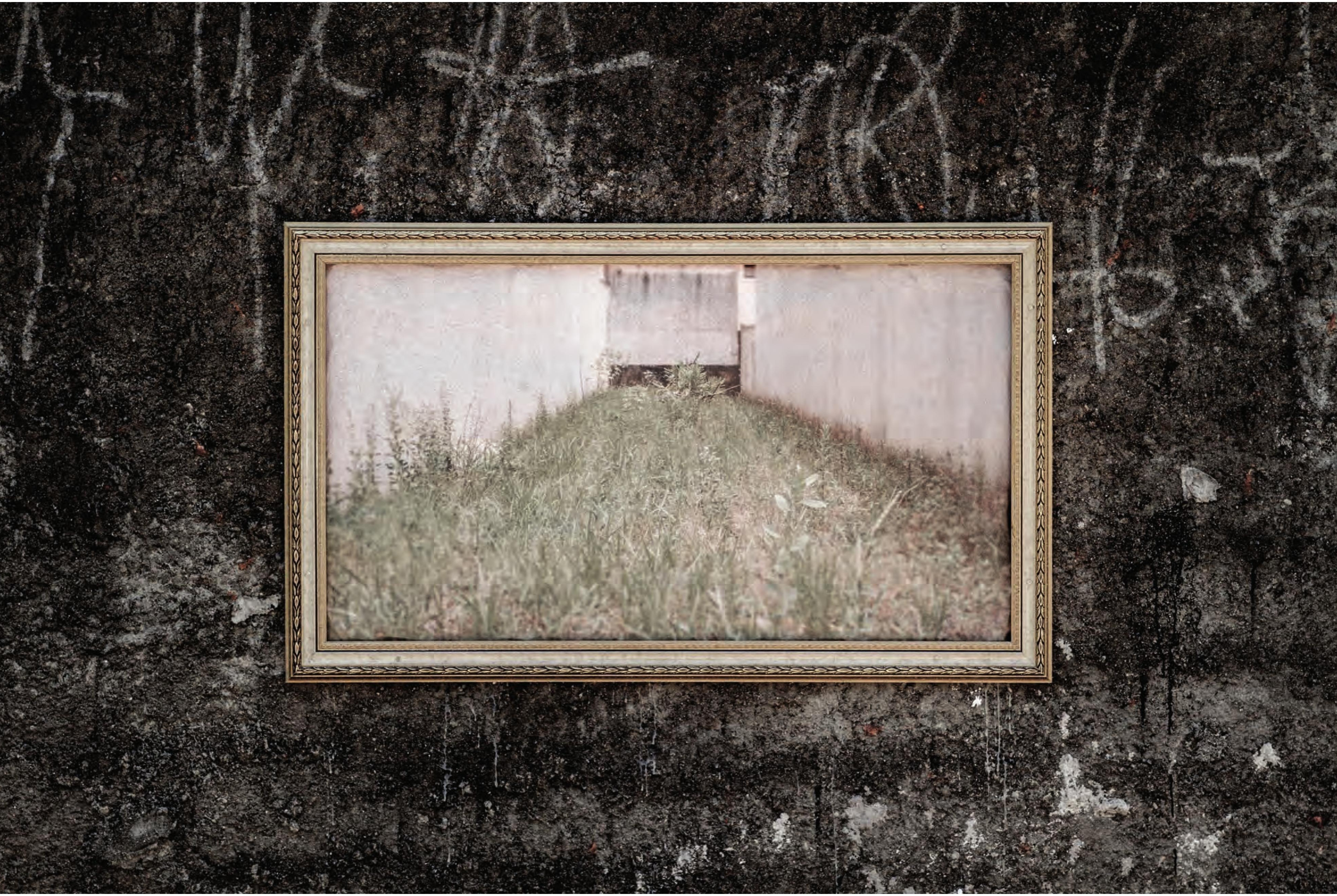




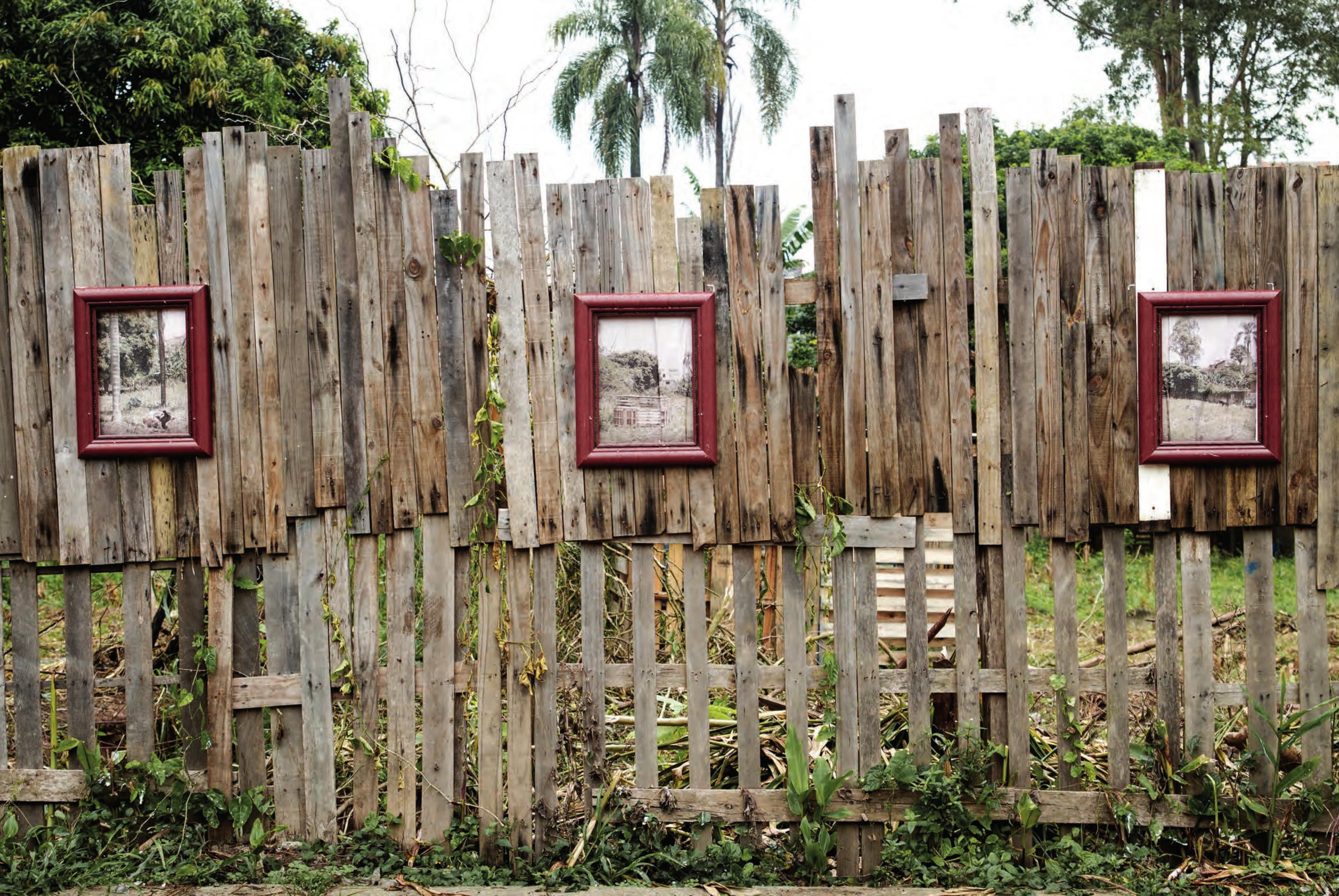




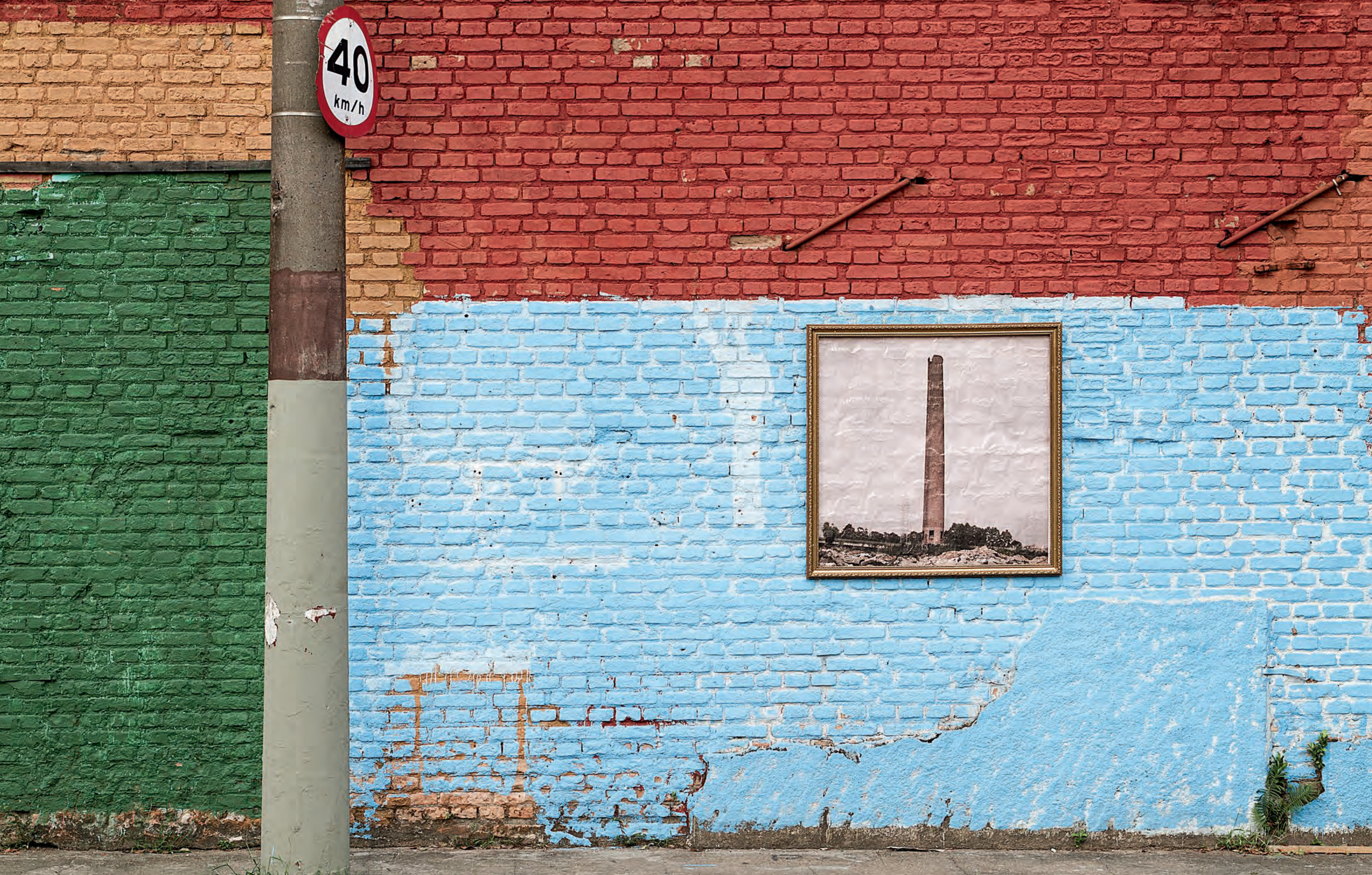




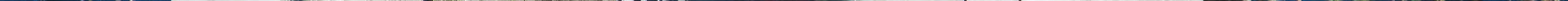




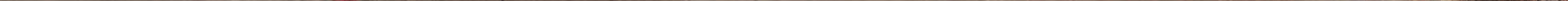




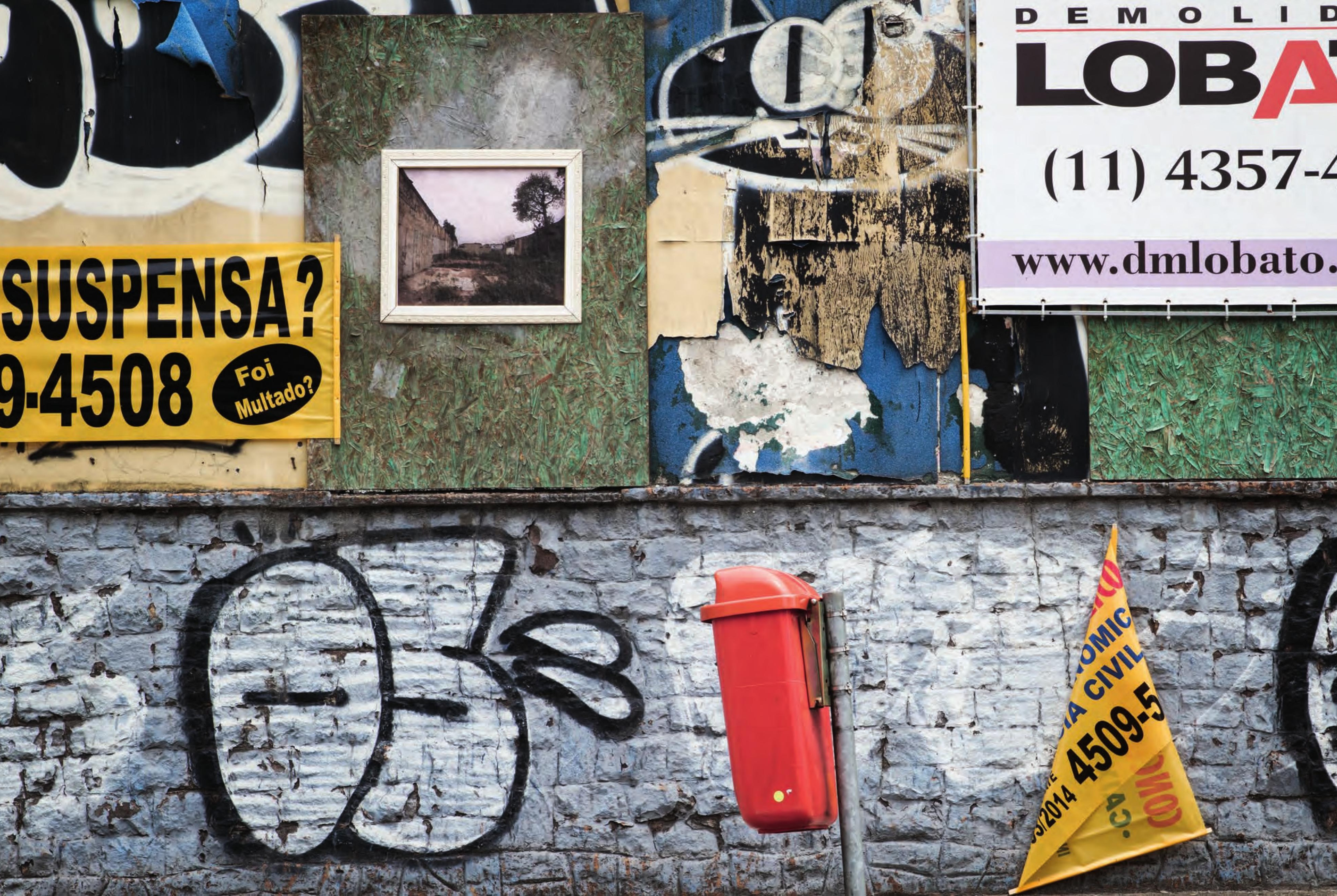




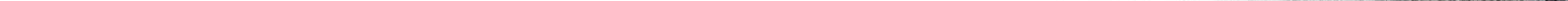


1.1.

0 engendramento do espaço público

O espaço urbano contemporâneo das grandes cidades pode ser visto como um paradigma da saturação, onde a justaposição de corpos, desejos e informações dão o tom de uma realidade cacofônica, veloz e muitas vezes asfixiante. No entanto, esse mesmo espaço atulhado pode servir também como uma imensa rede de conexões que possibilitam surpresas estéticas a cada esquina, por meio de intervenções artísticas inseridas no ordinário e constituintes de "frestas sensíveis" em espaços "anestesiados" pelas urgências cotidianas. Em meio a essa multiplicidade do espaço público urbano, artistas produzem sob uma condição dialética, ora sendo o oxigênio do organismo, ora sendo também parte de sua anóxia.

Composto de contradições inerentes à esfera pública, o espaço urbano é, em essência, o espaço próprio das diferenças, espaço comum em que a igualdade de participação e pertencimento constitui o fundamento. Contudo, no sentido oposto a esse conceito, atualmente são realizadas práticas de pacificação pela iniciativa privada e pelo Estado por meio de políticas e projetos urbanísticos que almejam homogeneizar o espaço público, despotencializando diferenças. Assim, o espaço público configura um campo de disputas no qual a cidade - como "lugar de uso" - é constantemente ameaçada pela "lógica da mercadoria", que nega as características fundantes desse espaço como lugar de diálogo e de compartilhamento, por meio de imposições que ambicionam emudecer e pacificar os conflitos que formam sua essência - propriamente público e comum 
Diante dessas tensões, a arte no espaço público conforma, por vias marginais, uma resistência à negação da acepção de público. Atuar na superfície urbana é, para os artistas, fazer uso comum da cidade, salientando suas tensões e buscando problematizá-las.

Para melhor refletirmos sobre o modo como o espaço público é abordado nos dias atuais, retornemos até a gênese do conceito, na Grécia Antiga, com vistas a compreender algumas questões da esfera pública.

Os gregos, ao criarem a esfera pública, desassociaram o poder da esfera privada com a criação da política. Até então, na Antiguidade, a vontade do déspota configurava-se em lei. Com a política, a lei passa a ser construída coletivamente através do

iálogo nas assembleias, tornando-a fruto do espaço público,

o lugar que possibilitava as trocas e as relações de igualdade entre os cidadãos ${ }^{6}$ na polis grega.

Em contraposição à esfera pública, alicerçada sobre a igualdade os lares gregos conservavam a esfera privada com características distintas do universo político. Hannah Arendt, em seu livro $A$ condição humana, diz o seguinte sobre essa questão:

Segundo o pensamento grego, a capacidade humana de organização política não apenas difere, mas é diretamente oposta a essa associação natural cujo centro é constituído pela casa (oikia) e pela família. 0 surgimento da cidade-estado significa que o homem recebera, "além de sua vida privada, uma espécie de segunda vida, o seu bios politikos. Agora cada cidadão pertence a duas ordens de existência; e há uma grande diferença em sua vida entre aquilo que the é próprio (idion) e o que é comum (koinon)". (ARENDT, 1983, p. 33)
A bios politikos, a que Hannah Arendt se refere, advém do pensamento aristotélico, que dividia a vida política em ação (práxis) e discurso (lexis). As vozes na esfera pública eram sempre ouvidas e serviam como fundamento pacificador político pois "ser político, o viver numa polis, significava que tudo era decidido mediante palavras e persuasão, e não através de força ou violência" (ARENDT, 1983, p. 35). Em contraposição, a esfera privada é descrita como a esfera da violência, onde é concebíve "ordenar ao invés de persuadir", configurando os "modos prépolíticos de lidar com as pessoas, típico da vida fora da polis característicos do lar e da vida em família, na qual o chefe da casa imperava com poderes incontestes e despóticos" (ARENDT, 1983, p. 36) sobre escravos e familiares.

Assim como na Grécia Antiga, atualmente a esfera pública e a esfera privada continuam a existir e coabitam o contexto urbano contemporâneo, com a diferença de que a política hoje em dia se estende a todas as esferas, em que na teoria todos são iguais. Entretanto, é comum observarmos "modos pré-políticos" que ameaçam a essência do espaço público, almejando silenciar a multiplicidade das lexis que Ihe é constitutiva e habita os espaços comuns. Podemos apontar esse efeito no processo de espetacularização das cidades; assim como no de gentrificação, que busca apaziguar as contradições e uniformizar os espaços públicos. Tais práticas de homogeneização são sempre verticais impositivas às comunidades que sofrem com pressões dos imperativos privados.

0 que nos é caro ao observar o pensamento da esfera pública grega, é que em tese, os espaços públicos contemporâneos herdeiros dos princípios gregos, "deveriam" ser lugares para as trocas, para o diálogo e para a construção de cidadania. 


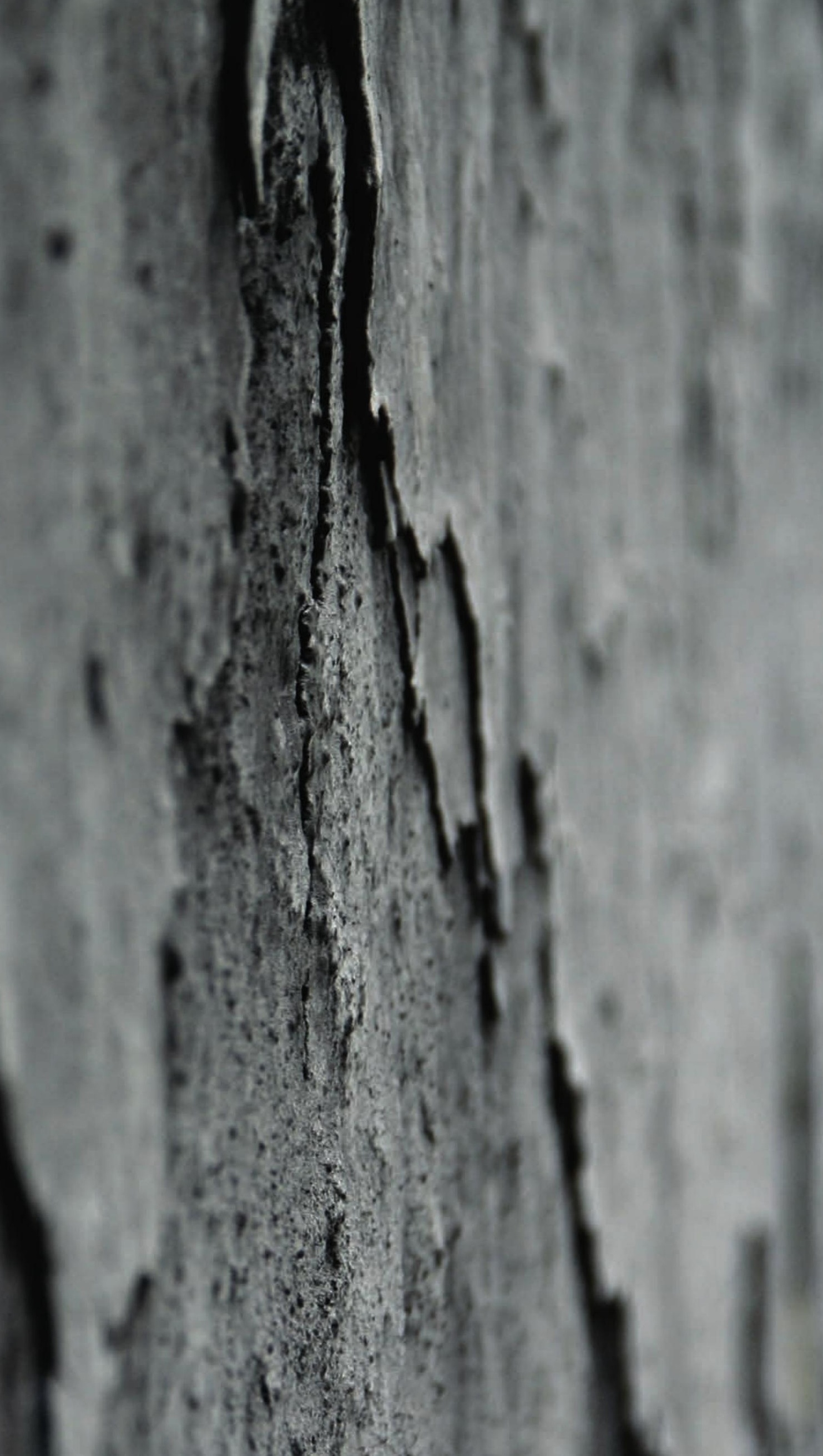


Entretanto, o que vemos é justamente o oposto nas instituições democráticas que corroboram com interesses privados, fazendo com que o discurso do Estado democrático se desarmonize em relação a sua práxis. Na contramão de um "ideal" de espaço público ao modo grego, a cientista política Chantal Mouffe

"Con vistas a sacar la luz la relevancia plítica democrática para las prácticas artísticas, quiero examinar sus la concepción del apacio público. La más importante es la de que impugna la difundida concepción en la que aunque en formas diferentes, se basa la mayoría de las teorías sobre el espacio público concebido como ámbito en el que puede surgir el consenso. Para el modelo agonista el espacio público es. al contrario, el campo de batalla en que se enfrentan diferentes proyectos hegemónicos, sin posibilidad alguna de conciliación final. Hasta ahora, he hablado del espacio público, pero debo apresurarme a concretar que no de un único espacio público. Según el planteamiento agonista, los espacios públicos son siempre plurales y la confrontación introduz o conceito de "modelo agonista", que compreende os conflitos como próprios ao espaço público, por conta da pluralidade de desejos e interesses que o compõe.

A fim de trazer à luz a relevância do modelo agonista de política democrática para as práticas artísticas, quero examinar suas consequências para a concepção do espaço público. A mais importante delas é a que contesta a concepção generalizada em que estão baseadas, embora de maneiras diferentes, a maioria das teorias sobre o espaço público, concebido como o lugar no qual o consenso pode surgir. Para o modelo agonista, o espaço público é, ao contrário, o campo de batalha em que se enfrentam diferentes projetos hegemônicos, sem possibilidade alguma de conciliação final. Até agora, falei do espaço público, mas devo apressar-me a especificar que não estamos tratando aqui de um único espaço público. Segundo a abordagem agonista, os espaços públicos são sempre plurais e a confrontação agonista se produz em uma multiplicidade de zonas discursivas. (MOUFFE, 2007, p. 64, tradução nossa) ${ }^{7}$

Essa constante confrontação plural nos espaços públicos atuais pode ser vista em inúmeros exemplos, seja em praças e parques enclausurados, seja nas constantes "limpezas" que funcionários de prefeituras fazem com jatos de tintas nos muros, com a finalidade de apagar as marcas deixadas sobre suas superfícies. Assim na relação arte e espaço público, o que poderíamos chamar de violência na esfera pública atual? Os diversos tipos de pichações, lambe-lambes e graffitis ilegais ou os monumentos oficiais que impõem ideologias de personagens antidemocráticos da história?
A resposta para essa questão reside justamente na ação daqueles que possuem o poder de permitir e proibir, por meio de decisões verticais sem correspondência consensual, distanciando-se da concepção do diálogo comum referido por Hannah Arendt. Entretanto, sobre esta questão, Chantal Mouffe diz que o conflito é próprio do espaço urbano, sendo sua essência "agonista", com conflitos irreconciliáveis e intrínsecos a sua condição

(...) 0 que quero dizer é que, enquanto Arendt insiste muito na pluralidade humana e em que a política trata da comunidade e da reciprocidade dos seres humanos, que são diferentes, nunca reconhece que essa pluralidade é a causa dos conflitos antagonistas. Segundo ela, pensar politicamente é desenvolver a capacidade de ver as coisas desde uma multiplicidade de perspectivas. Como atesta sua referência a Kant e sua ideia do "pensamento ampliado", seu pluralismo não é fundamentalmente diferente do liberal, porque está inscrito no horizonte de um acordo intersubjetivo. (MOUFFE, 2007 p. 65-66, tradução nossa)

E é em meio ao fogo cruzado do espaço público urbano, como lugar de conflitos, que as manifestações artísticas se inserem deixando de lado a busca consensual para o uso do espaço público e valendo-se de vias ilegais, sendo sua própria condição margina um dado de irreconciliação com as normas urbanas.

Neste âmbito, insere-se por exemplo, o graffiti, com sua vocação original de "ataque" à propriedade privada, habitando o limia entre arte urbana, "vandalismo" e desobediência civil. Outros exemplos também poderiam ser evocados, como é o caso de inúmeras apresentações teatrais e performances, entre tantas outras manifestações artísticas realizadas no espaço público

Todavia, polêmicas na relação arte e espaço urbano não são apenas
8 (...) lo que quiero decir es que, mientras Arendt insiste mucho en la pluralidad humana y en que la política trata de comunidad y la reciprocidad de los seres humanos, que son diferentes, nunca reconoce que esa pluralidad es la causa de los conflictos antagonistas. Según ella, pensar políticamente es desarrollar la capacidad para ver las cosas desd una multiplicidad de perspectivas. Como atestigua su referencia a Kant y su Idea del pensamiento ampliado , su pluralismo no es fundamentalmente porque está inscrito porque está inscrito acuerdo intersubjetivo." 


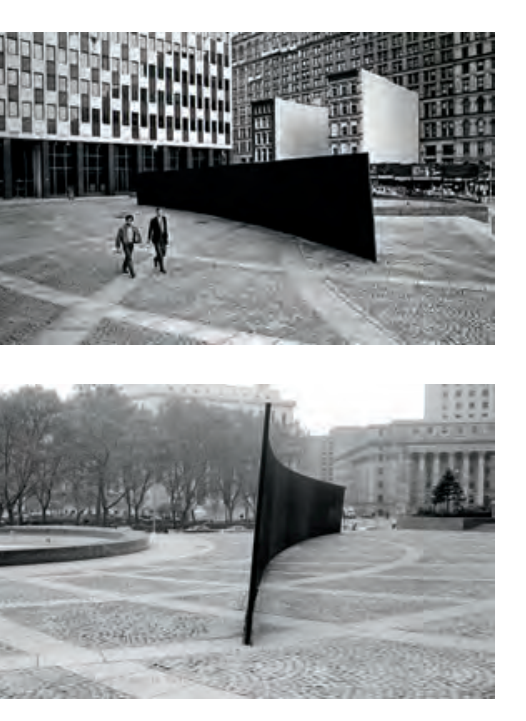

exclusividades das obras marginais, alguns trabalhos "oficiais" também podem potencializar uma variedade de controvérsias. É o caso da escultura Titled Arc, de Richard Serra, produzida na década de 1980 para o site specific da Federal Plaza, em Nova Iorque. 0 trabalho, inaugurado em 1981 e "destruído" em 1989, é um grande exemplo das relações de força entre interesses no espaço público. 0 trabalho, feito com aço corten de 36 metros de comprimento e 3,65 metros de altura, gerou inúmeras discussões entre usuários do espaço, governo, instituições e artistas, recaindo a principa argumentação contrária ao trabalho - e principal motivo para sua remoção - sobre sua característica de bloqueio da via pública.

Toda a polêmica em torno de Titled Arc expõe como mesmo um trabalho "oficial" de arte pública tem a potência de excitar inúmeras posições conflitantes com relação ao espaço urbano gerando um debate na sociedade sobre o uso do espaço comum a partir de interesses díspares. Sobre essa relação, a professora e arquiteta Vera M. Pallamin resume assim o potencia contraditório da arte pública:

Na relação entre manifestação artística e espaço público, essas questões tornam-se cruciais, pois permeiam o terreno a partir do qual a arte urbana nele instaura sua presença - com maior ou menor força e significação. Sendo partícipe na produção simbólica do espaço urbano, a arte urbana - compreendida no plano das relações sociais e não reduzida a uma dimensão estetizada repercute as contradições, conflitos e relações de poder que o constituem. (PALLAMIN, 2002, p. 105-106)

Sendo o espaço público contraditório e plural, nos debruçaremos a partir de agora sobre a apropriação dos muros das cidades como locais da lexis no espaço urbano contemporâneo.

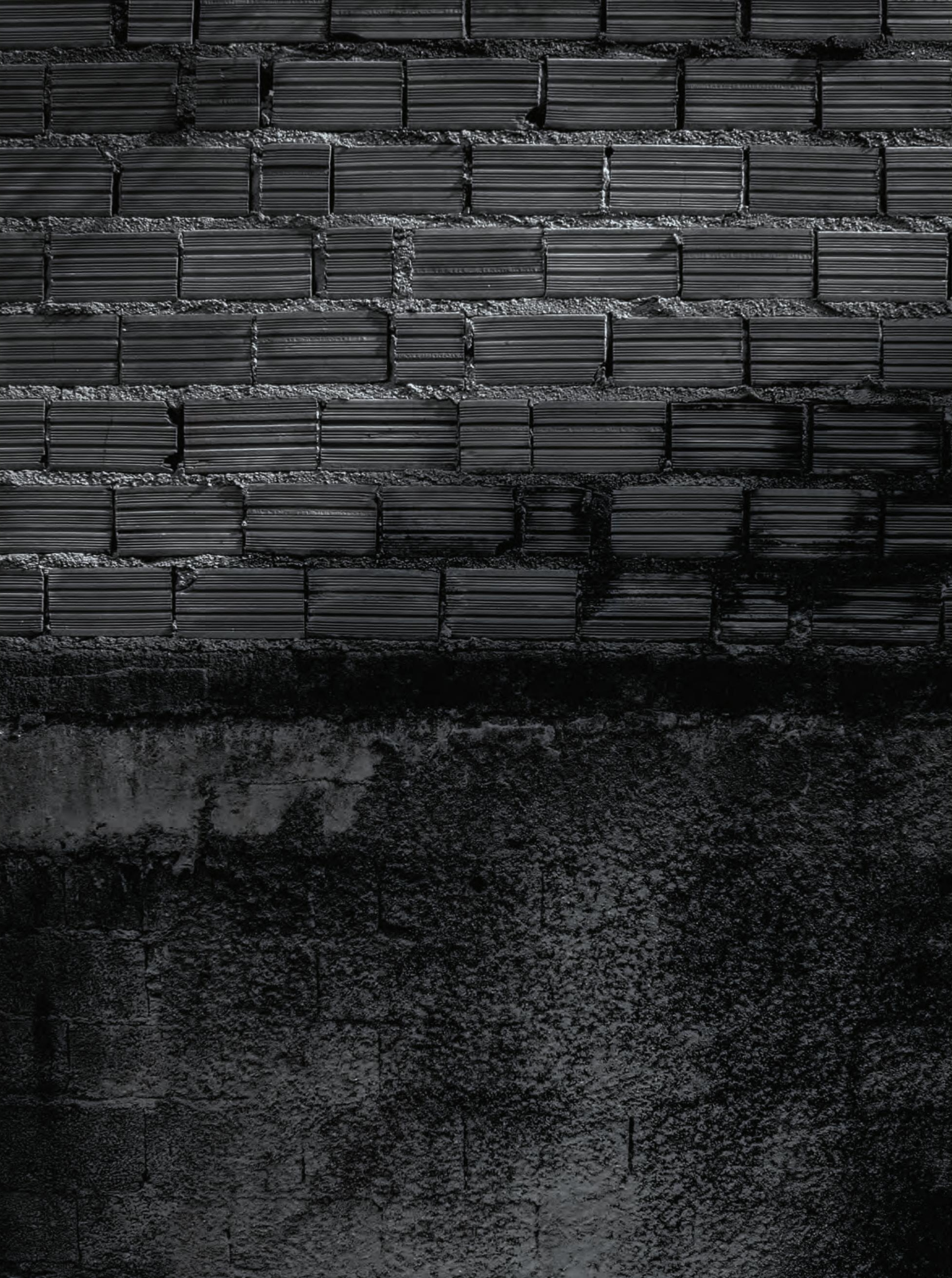



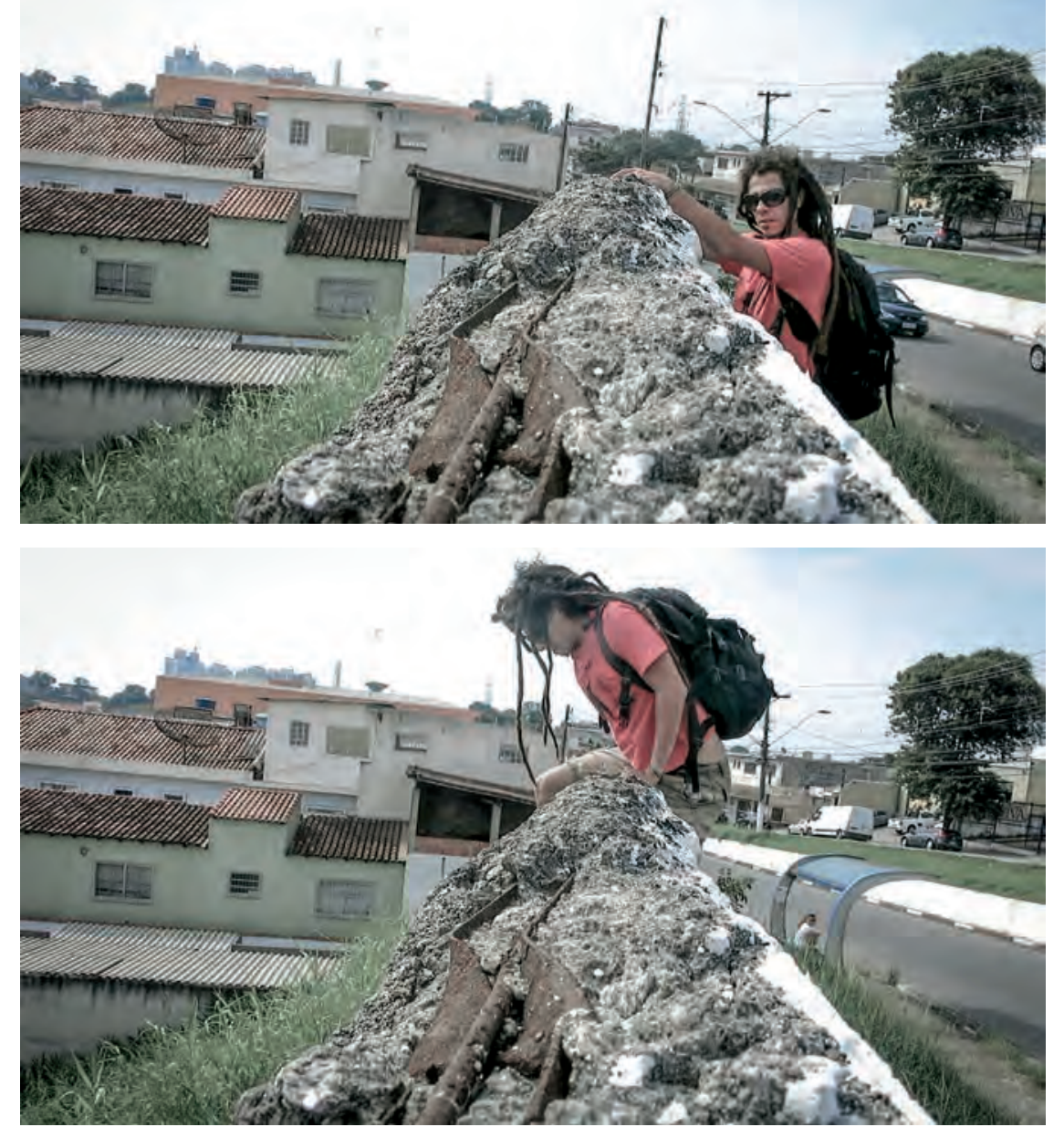

\section{0 fundamento do muro}

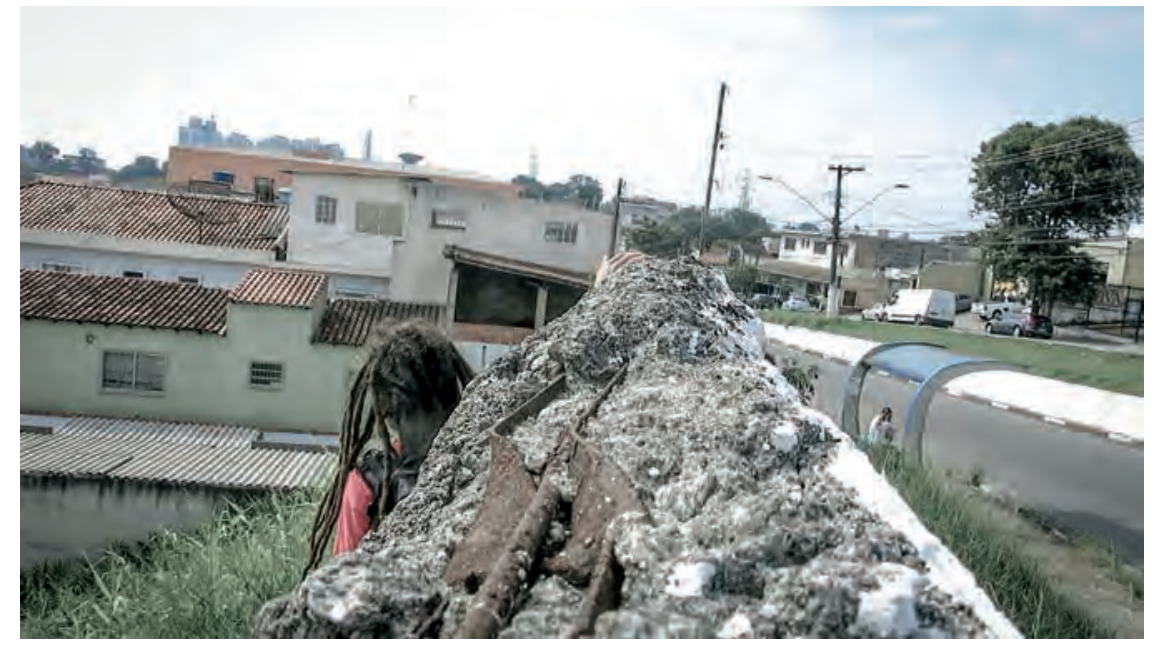

Os muros das cidades, onde artistas (e não artistas) encontram espaço para resistir às ideologias hegemônicas no espaço público contemporâneo, são estruturas simbólicas do poder patriarcal, como afirma a antropóloga Riane Eisler em seu livro 0 cálice e a espada, em que apresenta essa tese por meio de estudos ar queológicos na ilha de Creta, na Europa Antiga, onde existiram por séculos sociedades matriarcais pacíficas e igualitárias, que tinham como uma de suas características a ausência de muros. 0 habitat dessas sociedades matriarcais era composto de grandes fortificações e, a partir das invasões dos povos Kurgans (indoeuropeus) - datadas de aproximadamente 4.200 a.C. -, os grandes aglomerados são substituídos por casas semissubterrâneas e fortalezas altas, onde o homem-chefe governava. Deste modo, segundo Eisler, deu-se a transição da sociedade matriarcal na Europa Antiga para uma sociedade eminentemente patriarcal.

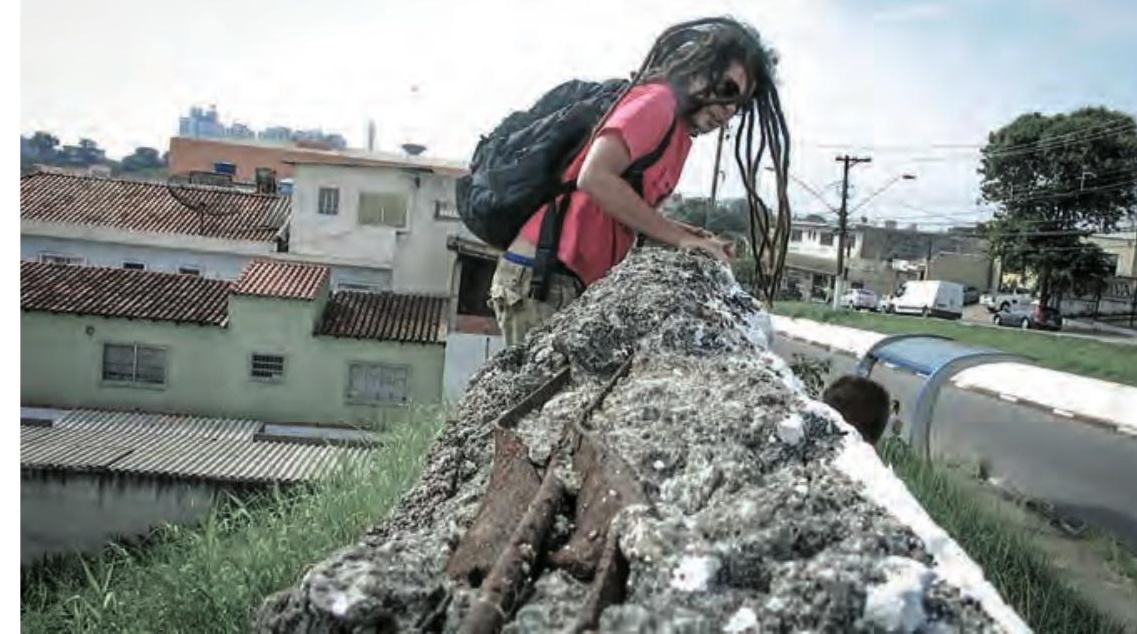

0 poder de dominar e destruir através da lâmina afiada gradativamente suplantou a visão do poder como capacidade de apoiar e nutrir a vida. A evolução das primeiras civilizações de parceria não foi apenas truncada pelas conquistas armadas - as sociedades que não foram simplesmente dizimadas sofreram uma mudança radical.

Os homens com o maior poder de destruir - os fisicamente mais fortes, mais insensíveis, mais brutais - ascendem ao topo da escala social à medida que em todo lugar as sociedades se tornavam mais hierárquicas e autoritárias. As mulheres - que como grupo são 
fisicamente menores e mais fracas que os homens, e que guardam maior identificação com a visão antiga de poder simbolizado pelo cálice que dá e sustém a vida - foram sendo reduzidas à condição que assumirão dali em diante: tecnologias de produção e reprodução controladas pelo homem. (EISLER, 2007, p. 103)

Desse modo, desde o período Neolítico o patriarcalismo passou a imperar nas sociedades antigas, pautadas na cultura da dominação, da guerra e da escravidão, com muros e fortificações que passam a ser fundamentais para a proteção contra outros povos. Essa seria também a gênese, segundo Hannah Arendt, da noção de esfera privada na Grécia Antiga, em que o chefe da família imperava com poderes despóticos. A própria palavra polis tem em sua etimologia

9 "A palavra pólis the originariamente 'muro circundante' ' ar que parión o lám noçãa de um 'círculo'

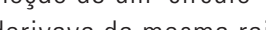
quivava da mesma raiz

que orbis. Encontramos a mesma relação $\mathrm{n}$
palavra inglesa town palavra inglesa tow que, originariamente, como no alemão Zaun EISLER, 2007, $73-74)$

10 No capítulo IV,"Sujeitos Enclausurados", a temática do muros é retomada partir de exemplos de segregações socioespaciais efetuadas pelos condominios
(a) nas cidades contemporâneas. a designação de "muro circundante" ${ }^{9}$, implicando uma interioridade onde a política era exercida na esfera pública, enquanto em seu exterior os "modos pré-políticos" ditavam regras próprias.

Era bem literalmente um muro, sem o qual poderia existir um aglomerado de casas, um povoado (asty), mas não uma cidade, uma comunidade política. Essa lei de caráter mural era sagrada, mas so o recinto delimitado pelo muro era político. Sem ela, seria tão impossível haver uma esfera política como existir uma propriedade sem uma cerca que a confinasse; a primeira resguardava e continha a vida política, enquanto a outra abrigava e protegia o processo biológico vital da família. (EISLER, 2007, p. 73-74)

Dessa maneira, vemos que a transgressão política nos muros contemporâneos carrega - pela própria natureza do "suporte" - uma série de simbolismos. Os muros ordinários do cotidiano urbano não são apenas estruturas pesadas em massa, mas também em história, haja vista os muros de Berlim, da Palestina do México, entre tantos outros ${ }^{10}$

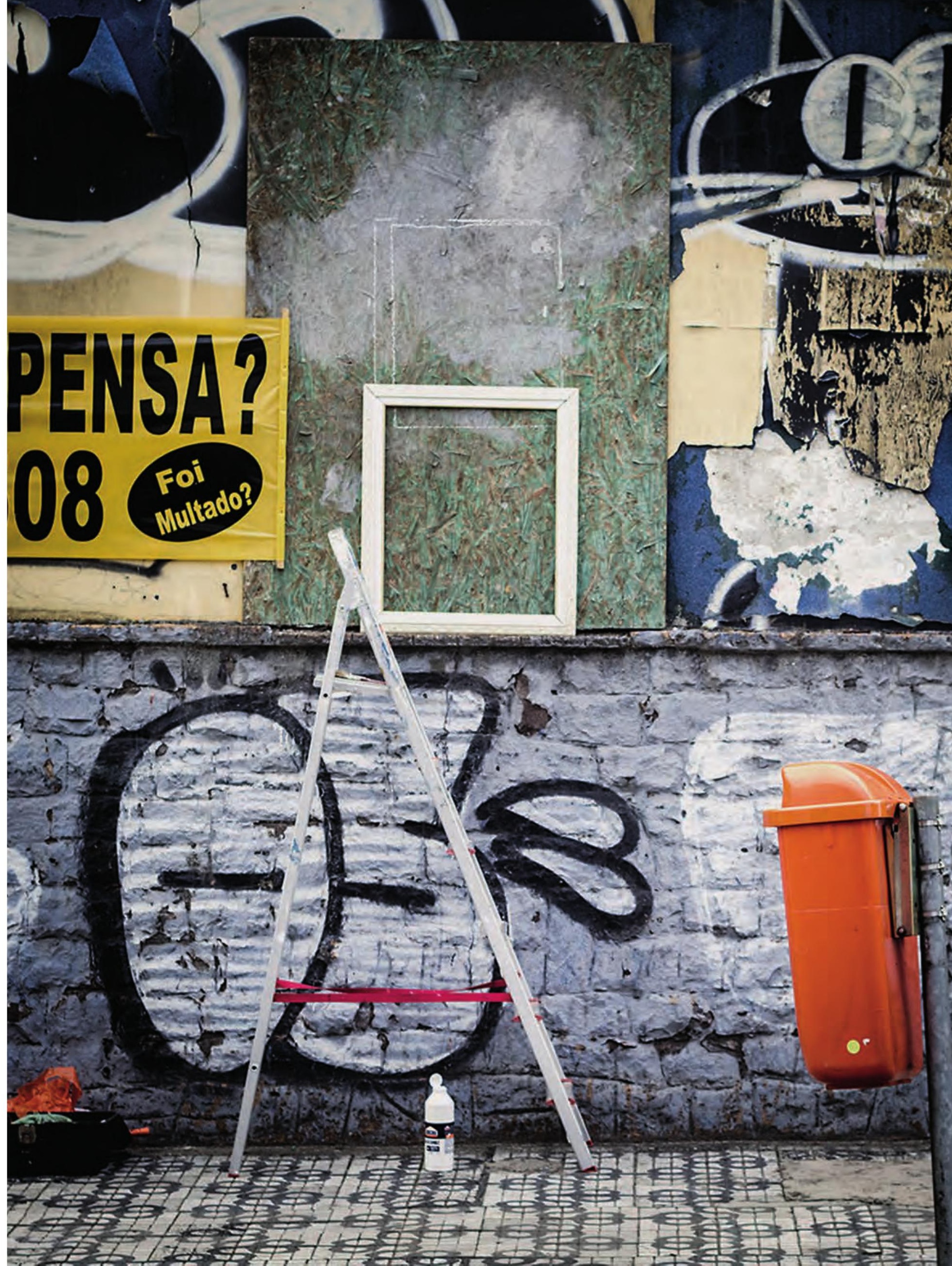


expecificidade única da experncia vivida no contato direto com a esclarece essa questão ao tratar da fotografia enquanto performan Apesar do amplo potencial de informação contido na imagem, ela informaçōes substitui a realidade tal como se deu no passado organizado estética e visuais de um fragmento do real, sum conjunto de fotografias não reconstituem os fatos passados [...] apenas congelam, nos limites do plano da imagem,

p. 114)

fotografia seleciona, com precisão, apenas certo detalhe da performance e este A fotografia seleciona, com precisão, a esse respeito surgem questionamentos recorte revela determinado olhar sobre a açáo. A pela imagem fixa, levando em conta a respeito das caracteristicas do olhar construido pela image da aço performática. Sendo a respeitimitações, potencialidades e qualidades de registro da ação performagem tanto pode assim, considera-se que nesse sentido, a visualidade construida pesejo de ser proficua quanto limitadora. Historicamente a fotografia tem, cinônimo de reproduzir, copiar, conservar as reproduzir o real visivel, fotografar cra sin não se limita a uma reprodução, sendo uma aparências. Mas logo é percebido que ela não sulages, sua noção passa de duplicação à sim uma criação, ou como afirma François Soulages, sua noçar uma nova realidade, sim uma craço. Entendida come fiç̧ãoela orienta-se no sentido de criar uma natureza ficcional ficção. Entendidaças à fotografia. $\mathrm{O}$ autor exalta a experiencia diva pela fotografia é um que só existe graças à fóng e postula que atingir a realidade objetiva pela fotogral requer um da imagem fotográfica, e postula que atografia de uma performance presencial requer um

olhar a partir da sua própria realidade. Em uma leitura preliminar a fotografia pode ser penceito advém da consciência prova, que atesta a existência daquilo que mõ da imagem fotográfica, em seu modo que se tem no processo técnico da prôa. Ou seja, sua capacidade mimética procede de especifico de constitućcnica. A fotografia atua, então, de modo a ser una contiguidade sua própria natureza teccica A

4. ocorrido, da existencia do seu refere.

. in ficial (1993,

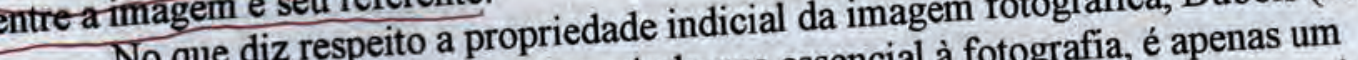
p.51) afirma que o princípio do traço, ainda quéfico ou seja, é apenas no instante da p.S1) afito breve no conjunto do processo fotografico, ou seja puro ato-traço. Assim o momento breve náa à luz que a fotografia pode ser considerada como puro ato-traço. As ode intervir, autor ressalta que é somente nessa fração de

- que vem antes ou depois e deliberado. Com isso, a capacidade de ate ptar a em reavaliaçáo. Essa revisão indica que o superficie da úntco testem do acontecimento refere-se apenas a construça de acha fundido a "E a constataçáo do testemunho que se vê gravado na fotografia se acha fundido a Segundo Kossoy "o testemúc " 2009, p.34).

processo de criaça do fotograra certo $\frac{\text { As informações visuais presentes }}{\text { proce }}$

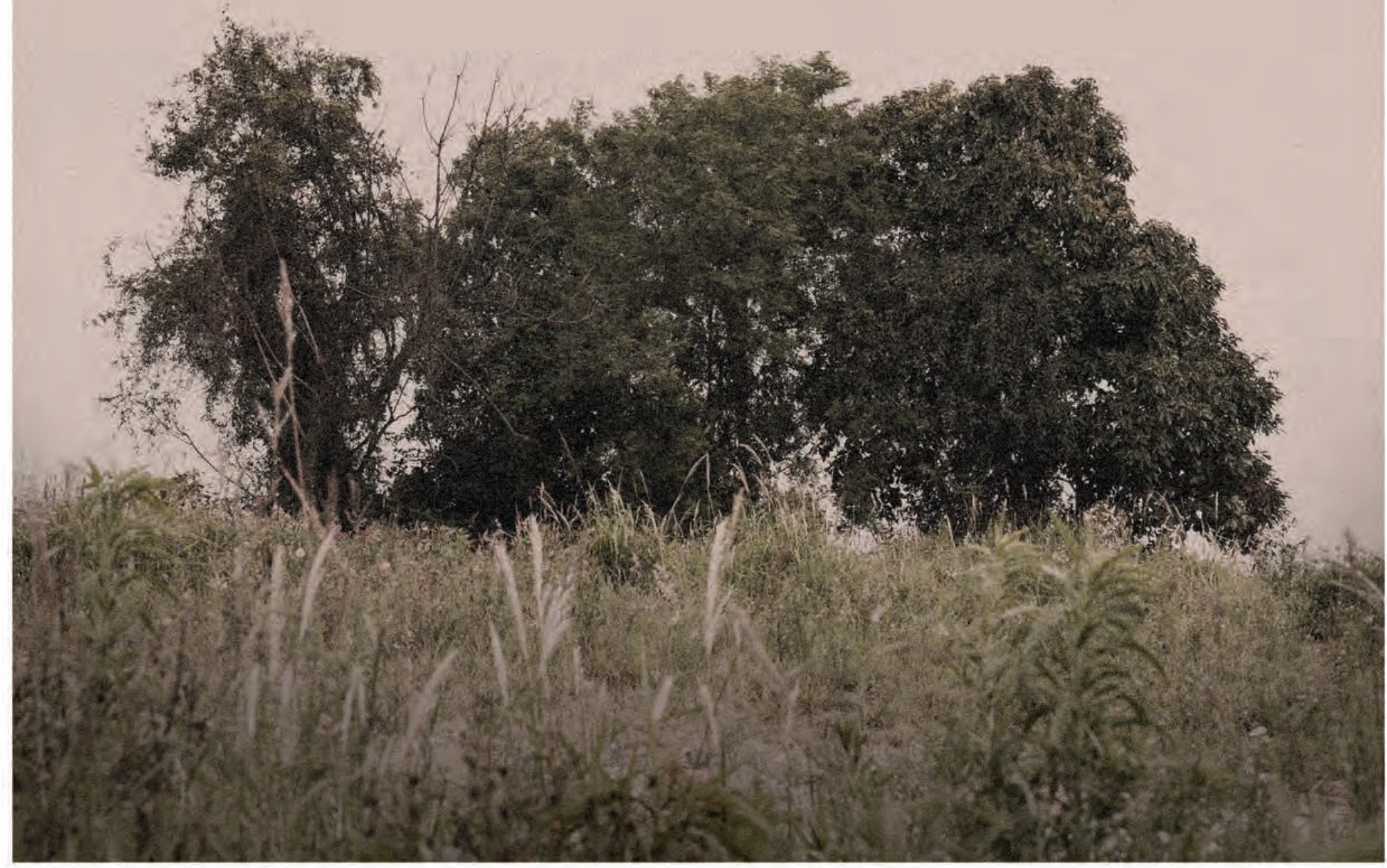
Amento da obra, visto que é apenas um registro circe acõo a fotografia enquanto sua 
Quer tenhamos consciência ou não, o espaço construído nos interpela de diferentes pontos de vista: estilístico, histórico, funcional, afetivo... Os edifícios e construções de todos os tipos são máquinas enunciadoras. Elas produzem uma subjetivação parcial que se aglomera com outros agenciamentos de subjetivação. (...) 0 alcance dos espaços construídos vai então bem além de suas estruturas visíveis e funcionais. São essencialmente máquinas, máquinas de sentido, de sensação, máquinas abstratas funcionando como o "companheiro" anteriormente evocado, máquinas portadoras de universos incorporais que não são, todavia, Universais, mas que pode trabalhar tanto no sentido de um esmagamento uniformizador quanto no de uma re-singularização liberadora individual e coletiva. (GUATTARI, 2012, p. 140)

A partir da discussão do dispositivo e do espaço como uma máquina de sentido, as intervenções artísticas no espaço urbano atuam como formas de resistência molecular que evidenciam a importância de se pensar sobre o espaço de forma crítica, pois observa as uniformizações que o contexto social impõe sobre os indivíduos.

Diante dessa série de premissas apresentadas, o trabalho Janelas foi pensado e produzido com vistas a discutir sobre os efeitos da arquitetura urbana no cotidiano e sobre o quanto não ter horizontes objetivos condiciona as subjetividades daqueles que habitam as cidades. Janelas confronta a lógica privada imposta ao espaço público e atua criticamente na paisagem urbana ao evidenciar questões estruturantes não apenas do espaço público, mas da arquitetura da sociedade como um todo.

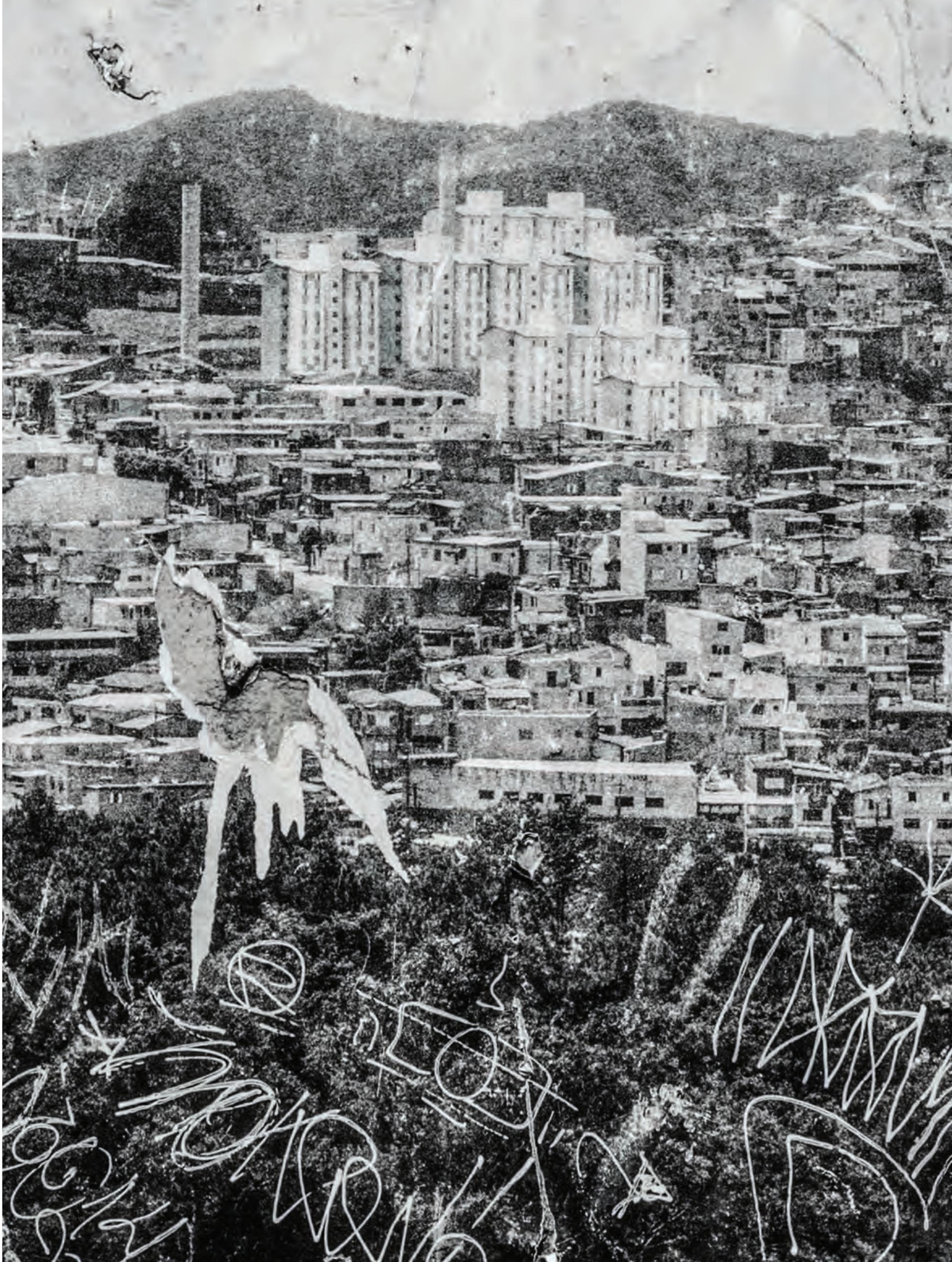




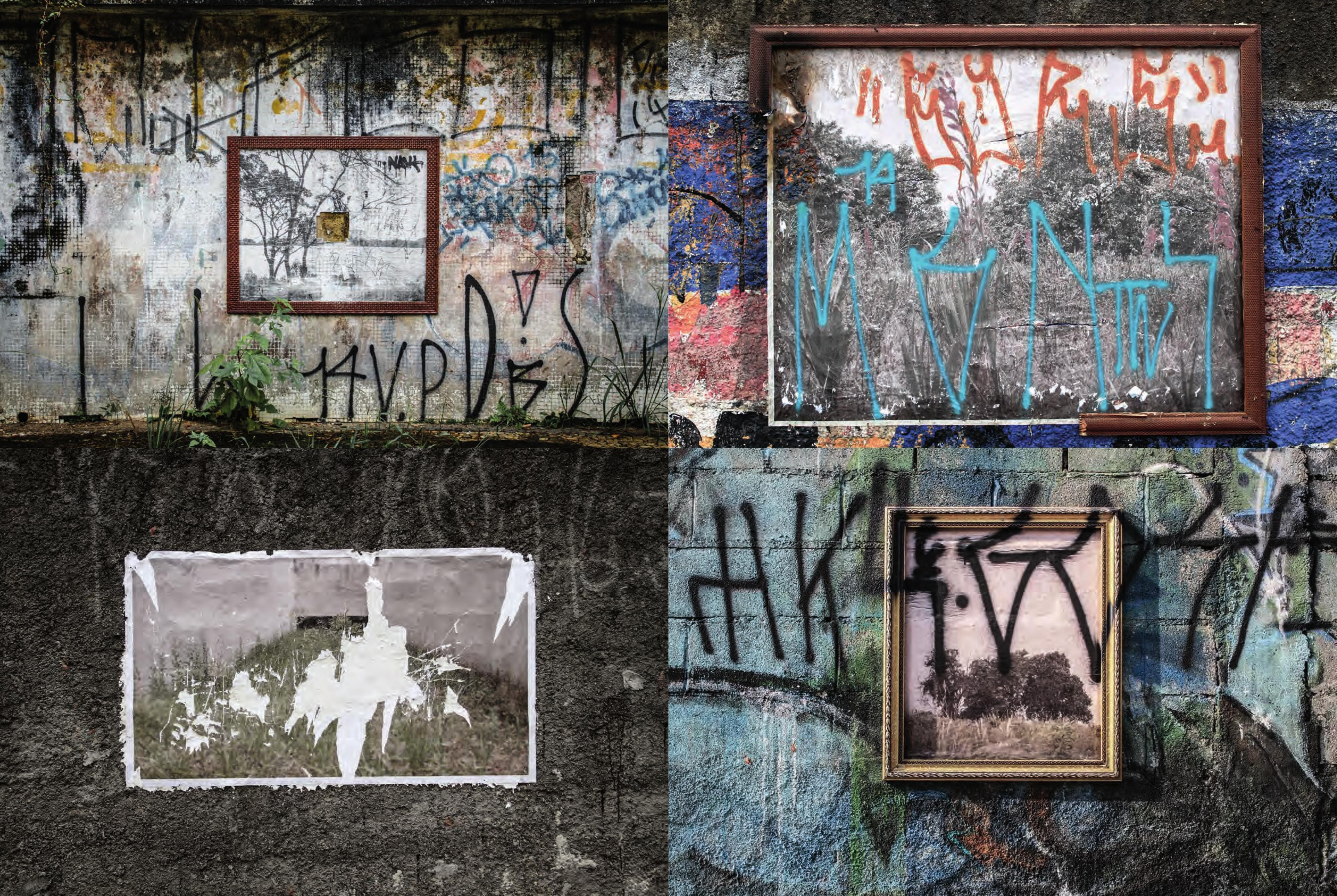




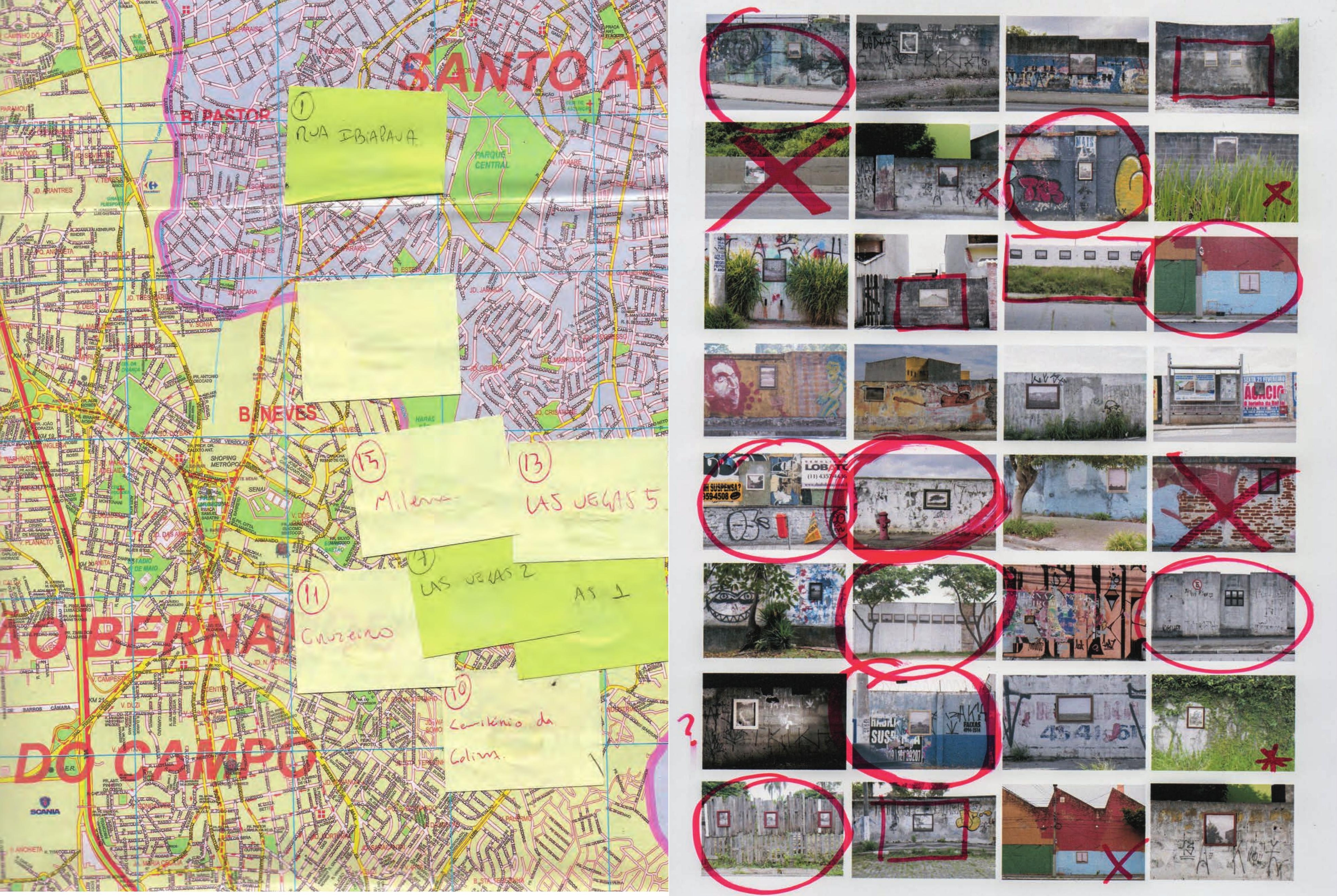


F.

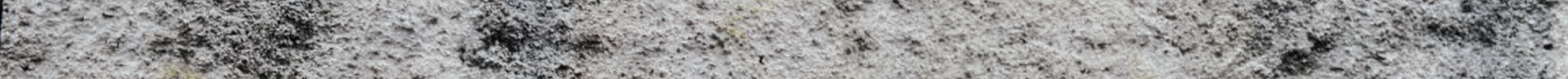

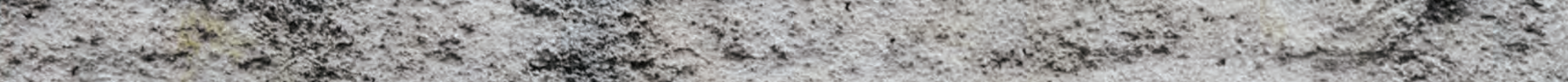

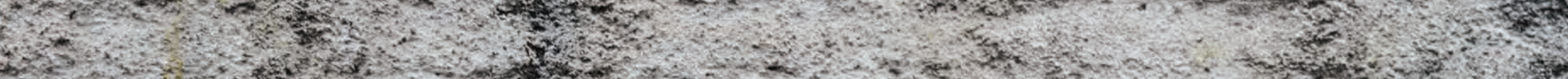

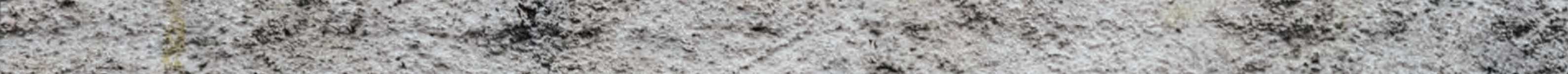

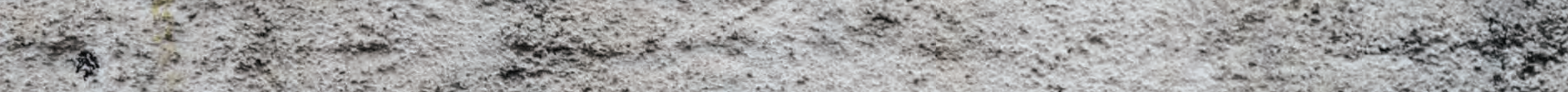
(4) \& $\because x^{2}$ (4.

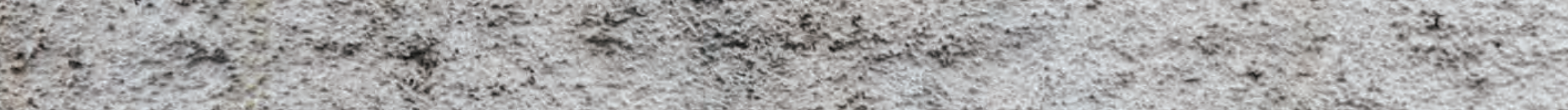
3
3

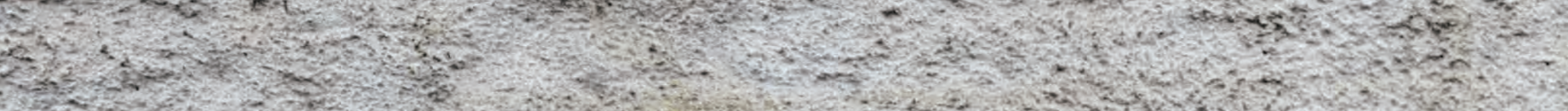

antion

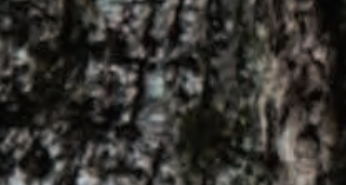
the Sis

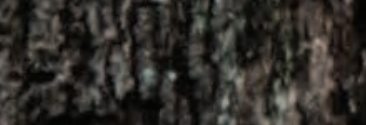




\section{I}

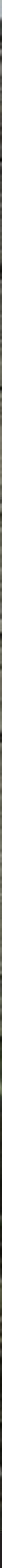




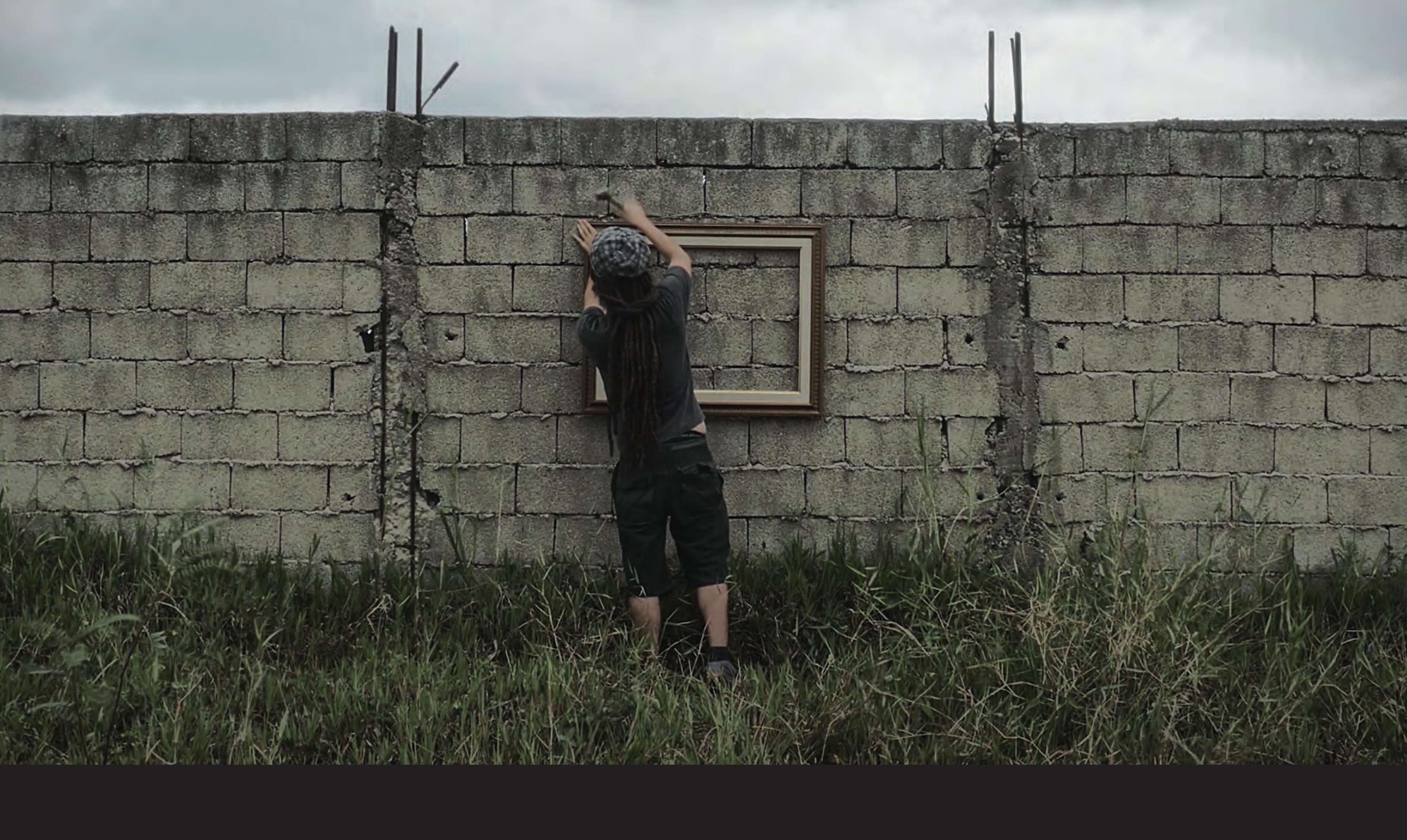




\section{IV}

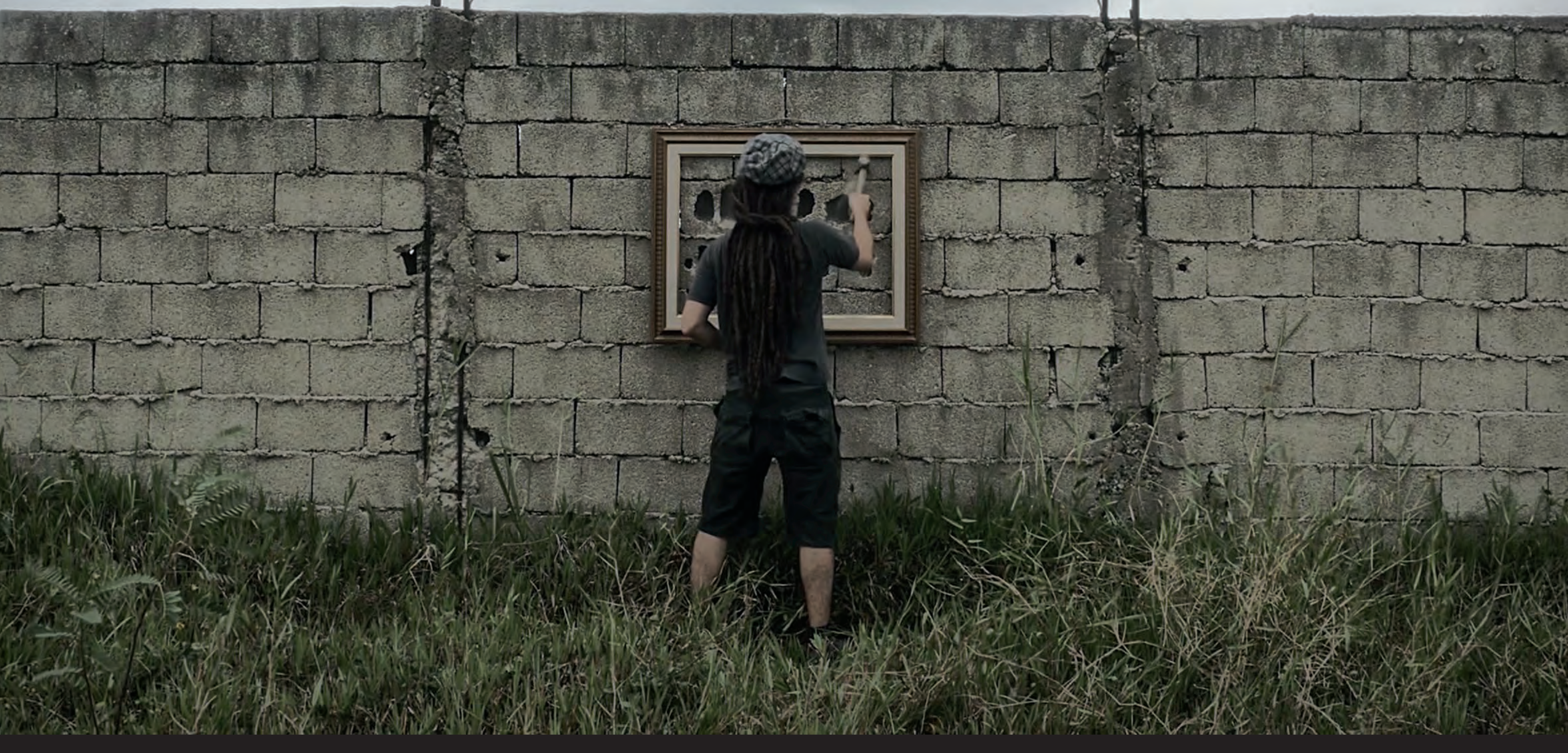




\section{IV}

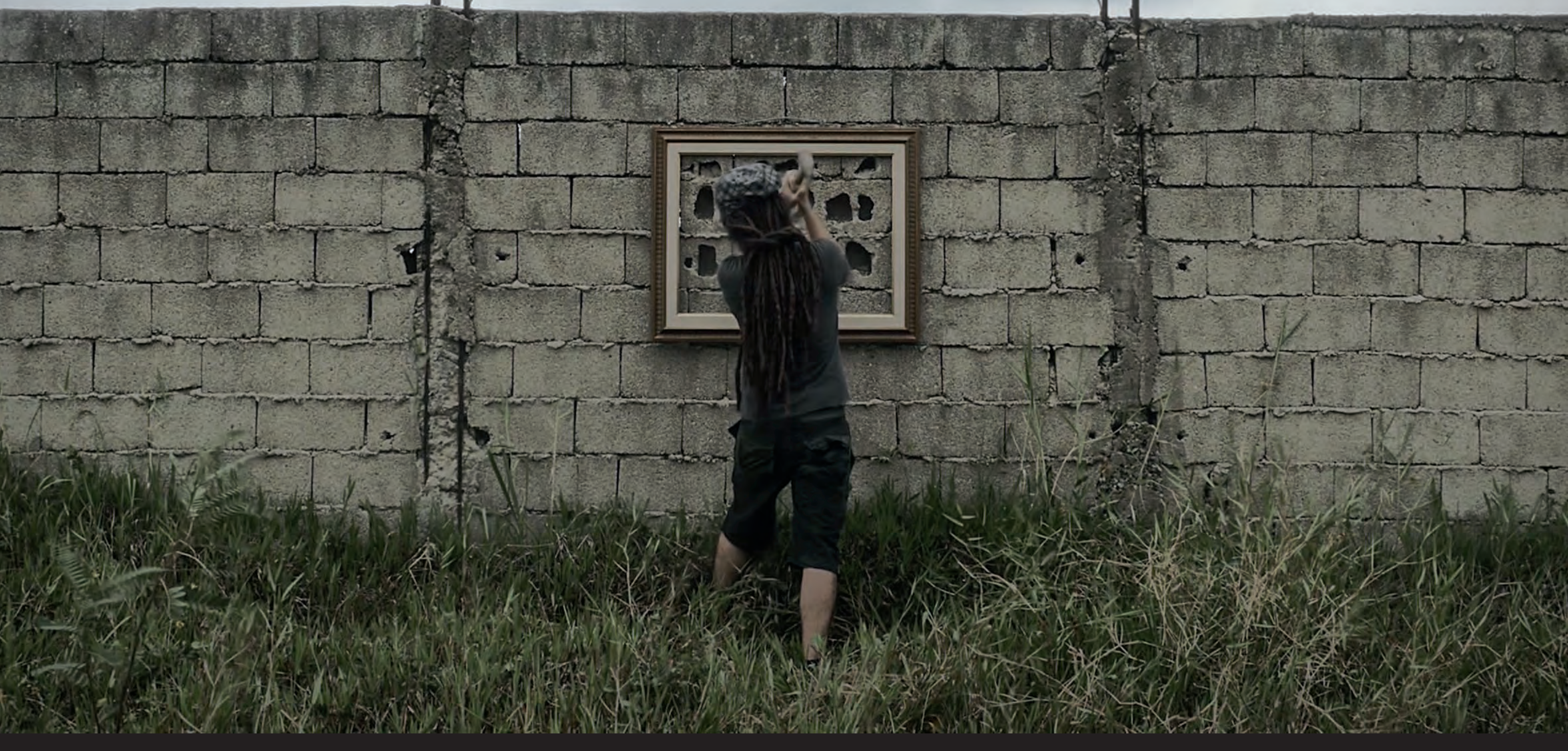




\section{I}

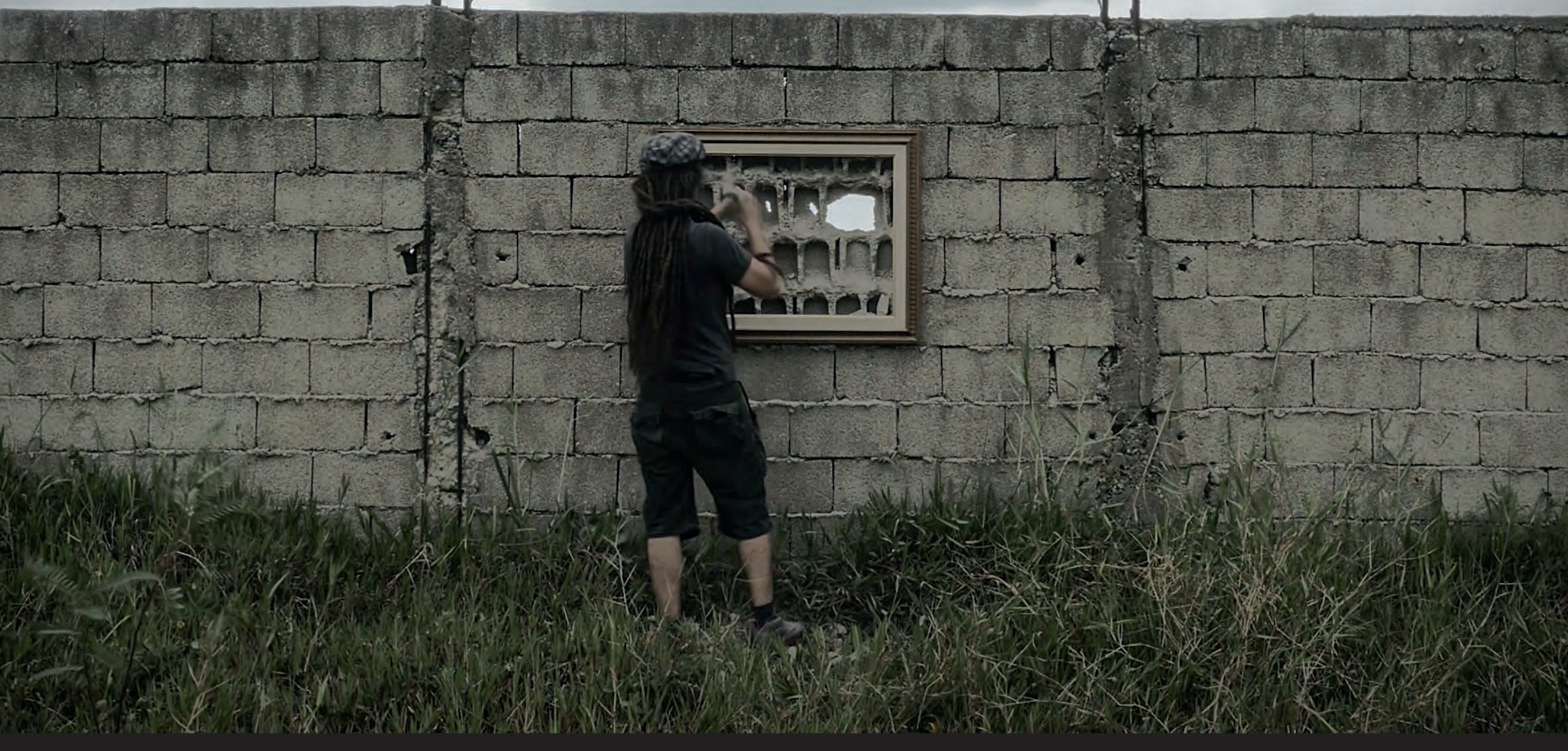




\section{I}

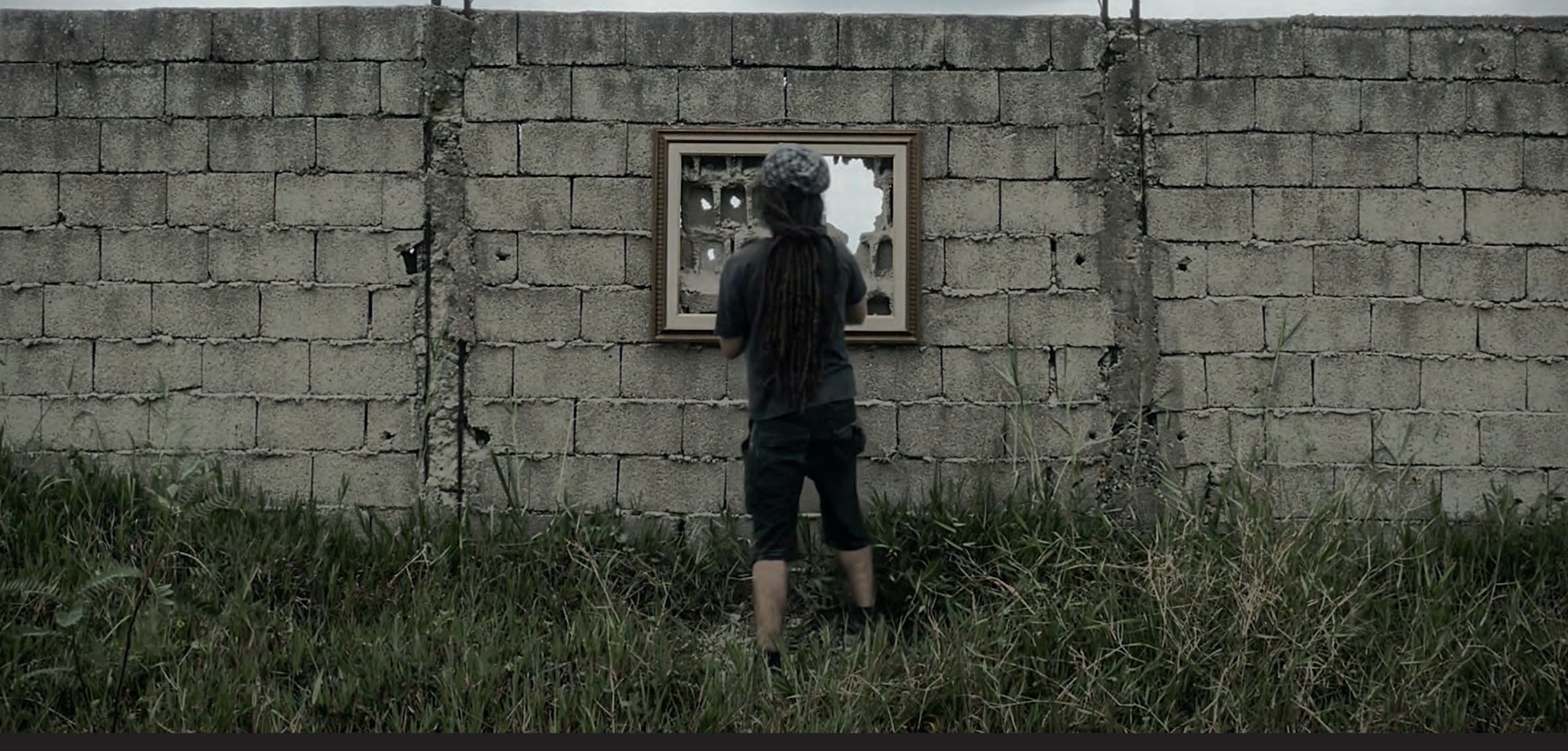




\section{I}

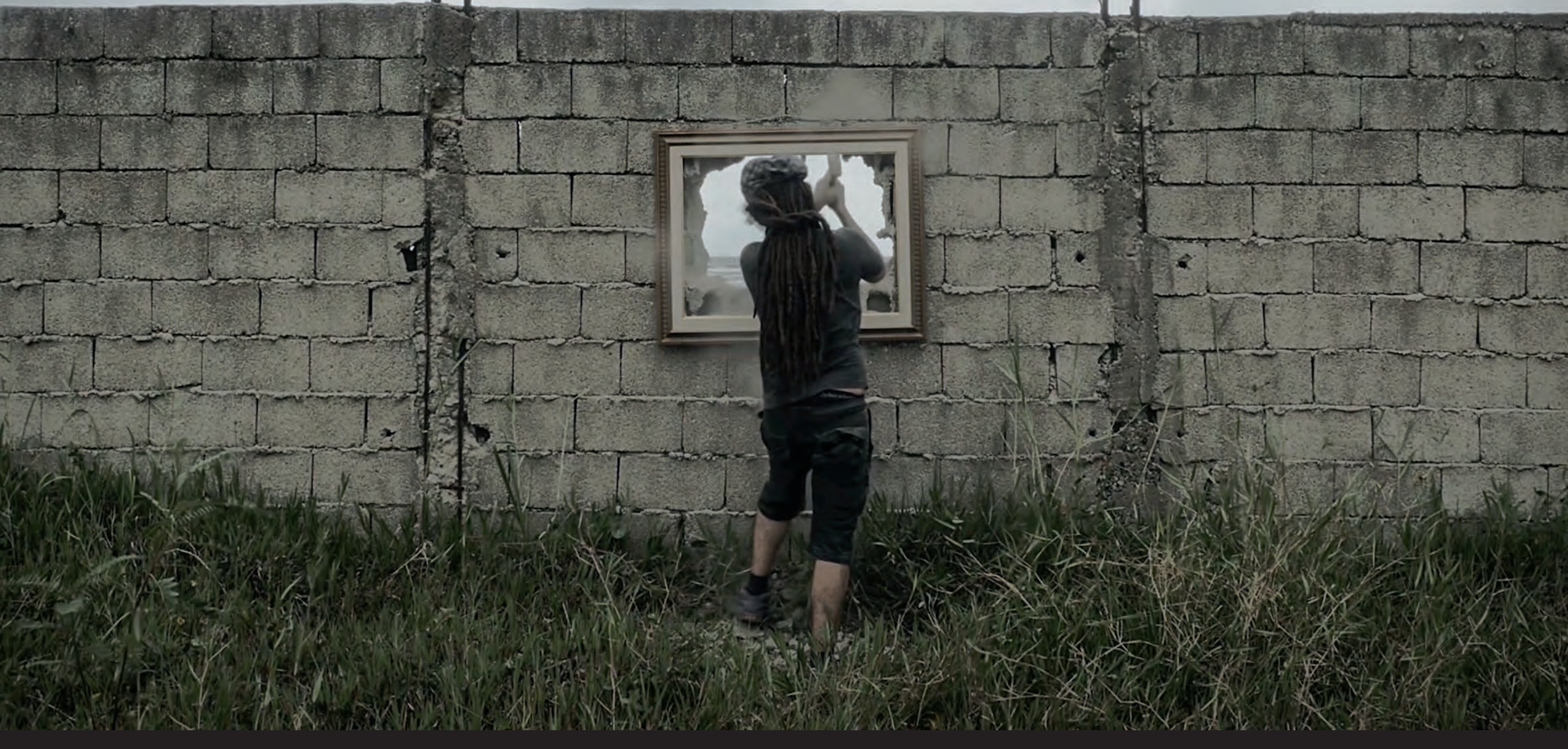





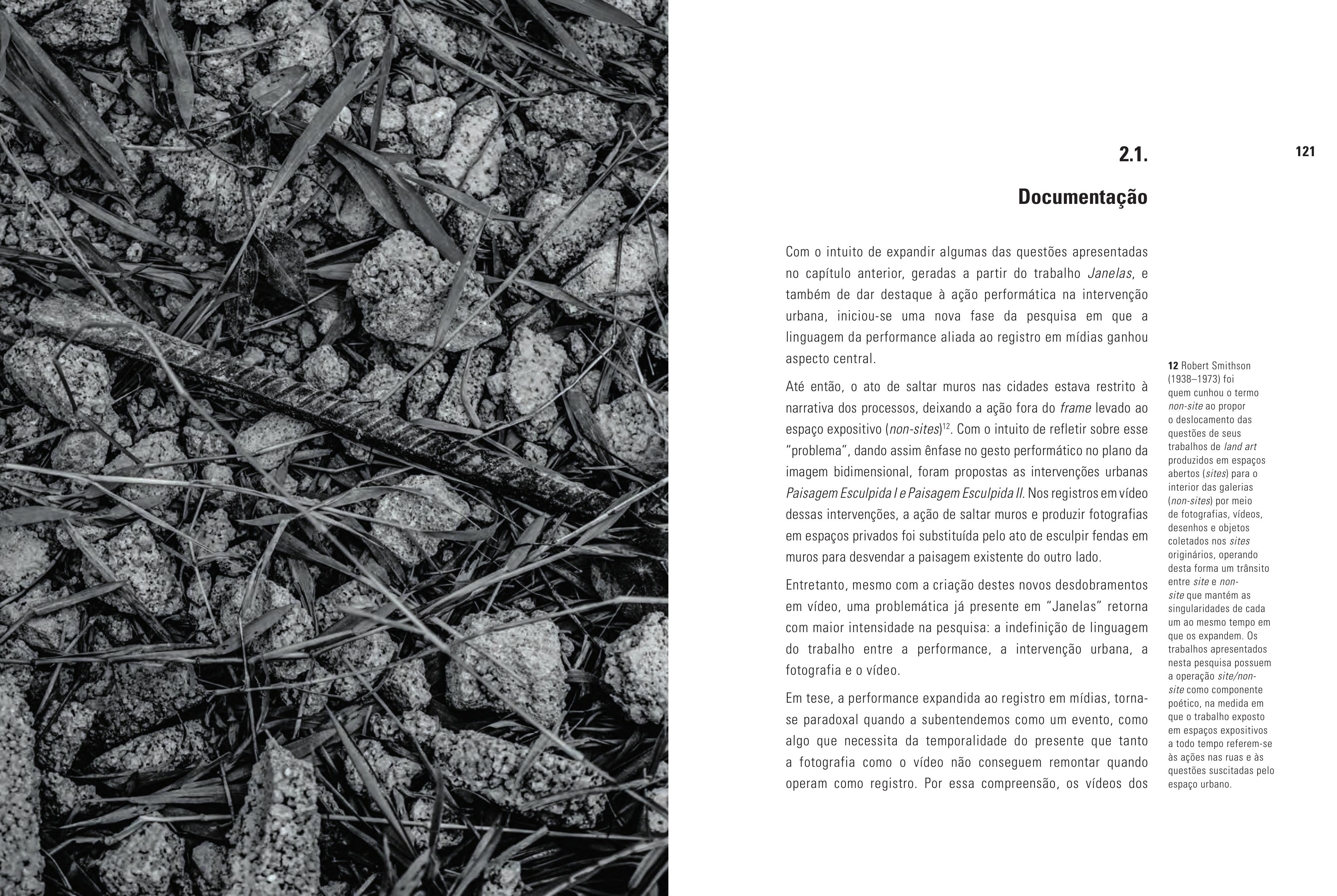




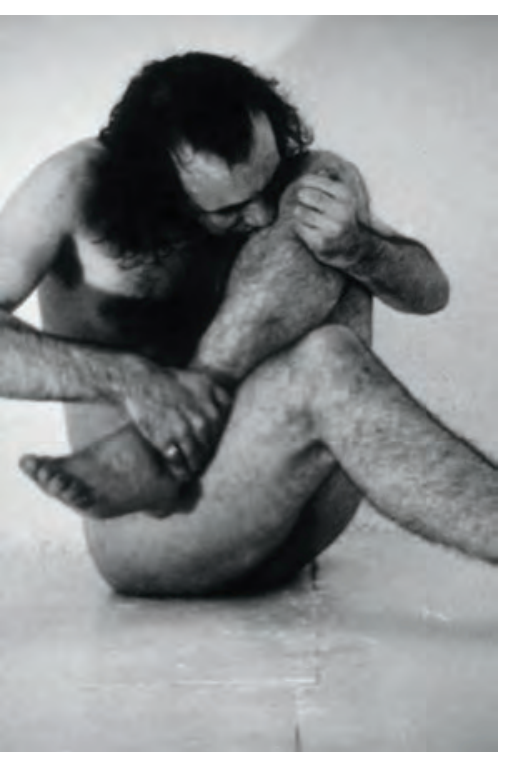

Vito Acconci, em posse do discurso de seu trabalho e ciente de que suas obras demandavam da experiência ao vivo permitia portanto apenas o registro fotográfico por este não dar a "dimensão global" dos trabalhos, o que o vídeo, por ter outra característica temporal, poderia almejar ao confundir-se como experiência da obra. Nesse aspecto, Robert Morris era mais radical, e afirmava que quaisquer registros trairiam seu trabalho, pois justamente nega seu espaço e tempo:

0 que desejo juntar, para o meu modelo de presentidade, é a inseparabilidade íntima da experiência do espaço físico e daquela de um presente continuamente imediato. 0 espaço real não é experimentado a não ser no tempo real. 0 corpo está em movimento, os olhos se movimentam interminavelmente a várias distâncias focais, fixando inúmeras imagens estáticas ou móveis. A localização e o ponto de vista estão constantemente se alterando no vértice do fluxo do tempo. (MORRIS apud FERREIRA; COTRIM, 2006, p. 404)

Pelos comentários de Vito Acconci e Robert Morris, a perspectiva que se apresenta é a de que a concepção de tempo real e de experiência física são fundantes para a relação do espectador com as obras. No entanto, paradoxalmente, outros artistas da mesma época de Acconci e Morris, tanto da performance quanto da land art, utilizaram os registros como ferramentas para alcançar um público maior, através da memória de ações efêmeras em mídias, ou de pontos de vistas fotográficos de obras construídas em lugares de difícil acesso. A lista de artistas que se enquadram neste grupo é enorme, podemos citar alguns como: Robert Smithson, Walter de Maria e Michael Heizer na land art; e Joseph Beuys, Chris Burden e Marina Abramovic na performance art, entre tantos outros.

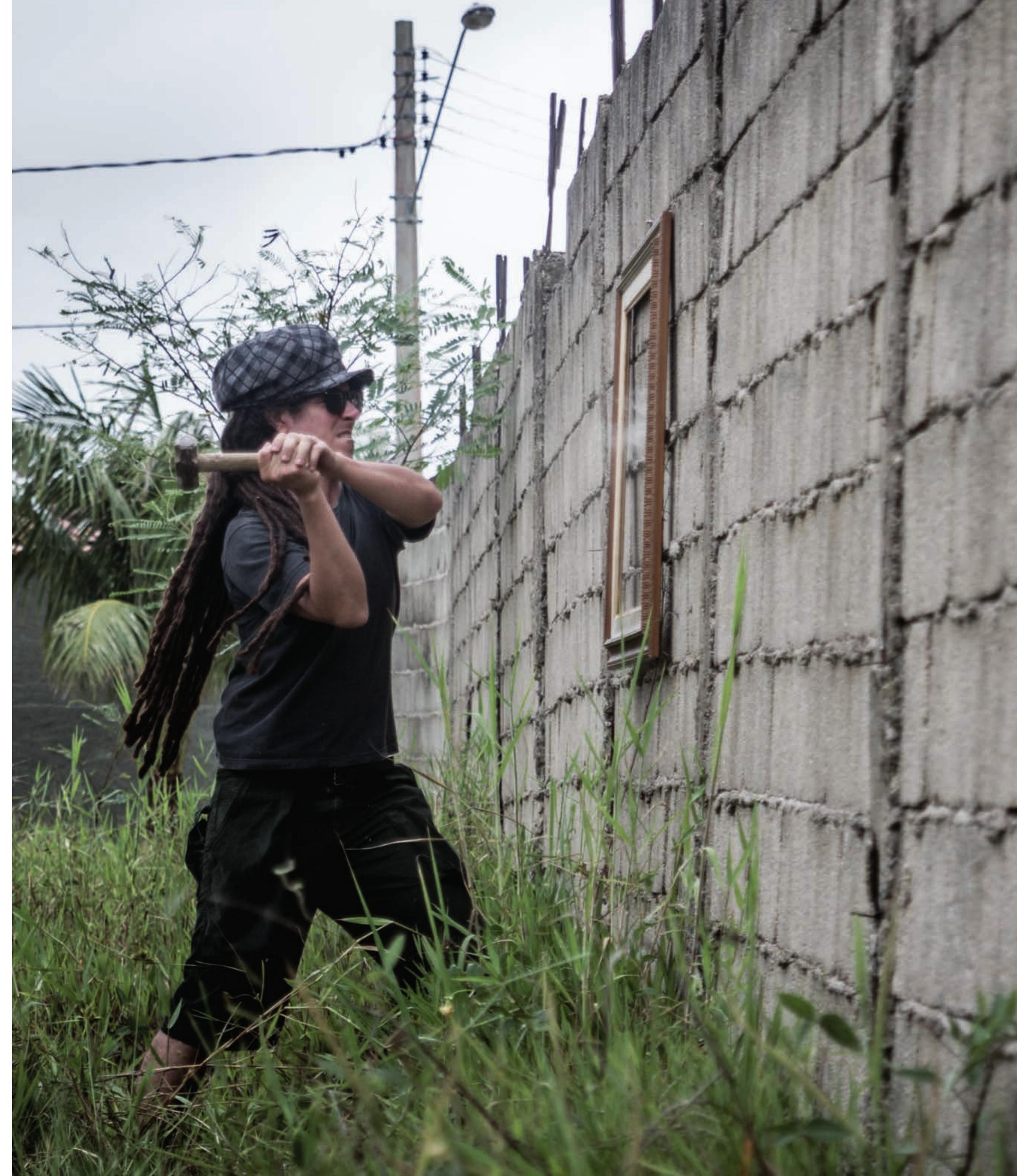


13 "Performance's only life is in present. be saved, recorded documented, or otherwise participa the circulation of representations of it does, it becomes performance"

14 A tradução literal de liveness é "vivacidade Aqui, no entanto.

podemos aproximá-la à
noção de "presentidade", roça de presentidade .

15 "Performance occou over a time which wil no be repeated. It can be performed again, bu this it self marks it as (19, p. 146) 1996, p. 146

16 "Em todo contecimento existe realmente o momen presente da efetuação. acontecimento se encarna em um estado de coisas, um individuo. uma pessoa, aquele que designamos dizendo: eis aí, o momento chegou; e o futuro e o passad do acontecimento não se julgam senão em unção deste presente

definitivo, do ponto de vista daquele que encarna." (DELEUZ 2015, p. 154)
Diante desta contradição, Peggy Phelan apresenta, sobretudo para o campo da performance, o conceito de liveness como elemento fundamental à experiência dos trabalhos. Segundo ela:

A única vida da performance está no presente. A performance não pode ser salva, gravada, documentada ou participar da circulação de representações de representações: uma vez isto realizado, torna-se algo diferente da performance. (PHELAN, 1996, p. 146 tradução nossa) $)^{13}$

A perspectiva de Peggy Phelan sobre a impossibilidade de chamarmos um registro de obra está na irrevogabilidade da condição liveness ${ }^{14}$ que a autora apresenta em seu texto, para a qual o registro, por suas especificidades, subtrai o fluxo temporal do acontecimento do trabalho. Phelan afirma que uma performance pode ser repetida, mas nunca reproduzida (PHELAN $1996)^{15}$, restando para a documentação - seja ela em fotografia ou vídeo - apenas o caráter de memória e nunca de reprodução. Peggy Phelan está embasada no pensamento de Walter Benjamin sobre "a obra de arte na era de sua reprodutibilidade técnica", em que "mesmo na reprodução mais perfeita, um elemento está ausente: 0 aqui e 0 agora da obra de arte, sua existência única, no lugar em que ela se encontra" (BENJAMIN, 1985, p. 167). Assim, a autenticidade dos trabalhos escapa a qualquer tipo de reprodução de seu original, que, quando nos referimos à performance, estamos apontando para um acontecimento ${ }^{16}$.

Philip Auslander, também pesquisador e teórico de performance art, possui uma perspectiva completamente diferente sobre o tema. Segundo ele, a autenticidade da performance não está apenas na condição liveness, mas também na relação entre a performance e 0 público, que pode bem ser realizada a partir do registro como projeto estético. Auslander traz assim uma perspectiva "fenomenológica ao invés de ontológica" à questão, ao afirmar possibilidades de 0 trabalho se efetuar a partir de mídias de registro na relação com o espectador, podendo coexistir com o outro tempo do trabalho primeiramente realizado. Desse modo, a noção de autenticidade do evento se veria multiplicada pela relação, em diversas linguagens, entre imagem e público. Nas palavras de Auslander:

Nosso sentido de presença, poder e autenticidade pode muito bem derivar. Não de tratar o documento como sendo um ponto de acesso indexical para um evento passado, mas de perceber documento em si como uma performance que reflete diretamente como um projeto estético de um artista e para o qual nós somos o público presente. (AUSLANDER, 2013, s/p.)

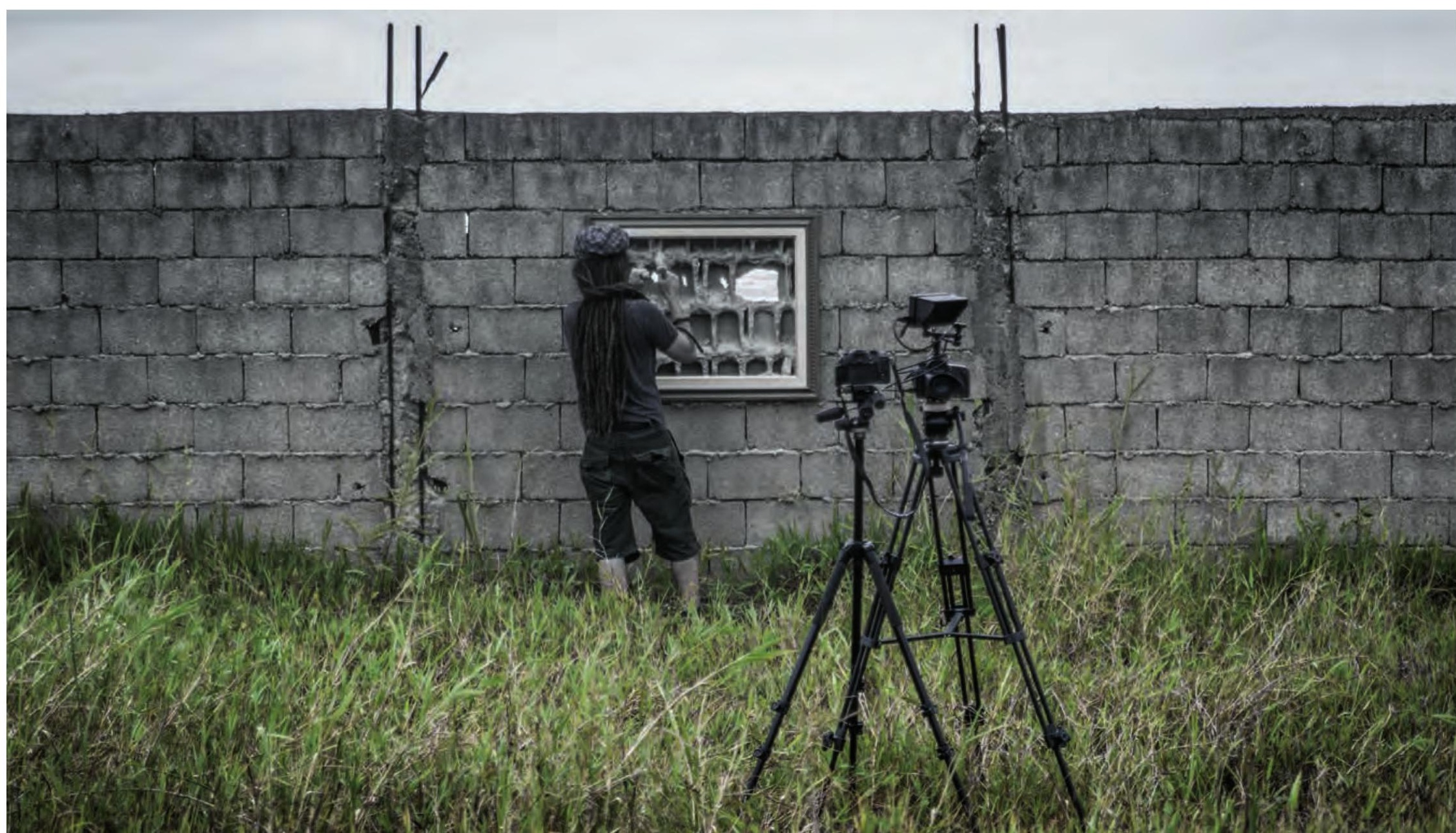




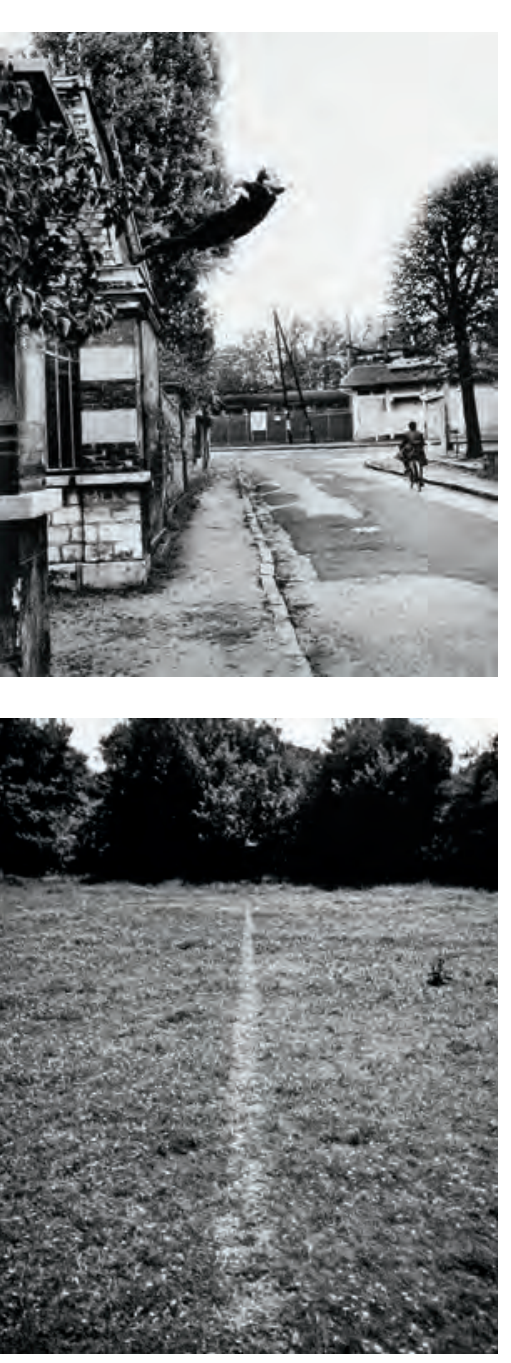

17 No Brasil, é comu ceferir a este trabalho como "Salto no Vazio".
A perspectiva fenomenológica de Philip Auslander alarga 0 conceito de performance, ampliando-o para obras icônicas da fotografia, como é o caso do L'Homme dans l'espace $(1960)^{17}$ de Yves Klein, uma fotomontagem que representa uma situação que de fato nunca aconteceu como representada. Assim como também as fotografias de Richard Long, como em A line made by walking (1967), em que o artista por meio de seu rastro na paisagem remete a uma ação realizada, construindo deste modo, um trabalho que habita 0 espaço entre a performance e a fotografia.

A partir dessa discussão entre artistas e teóricos, podemos retornar aos trabalhos Janelas, Paisagem Esculpida le Paisagem Esculpida I/ e interpretá-los por duas chaves de leitura: partindo da concep̧̧ão da obra na rua como aurática, embasada no conceito de liveness; e também no registro como um projeto estético, abordando os trabalhos a partir de suas camadas.

Desse modo, podemos também identificar três tipos de públicos para os trabalhos: o da performance (operações no espaço público); 0 transeunte (que se depara, em seu cotidiano, com as intervenções já acabadas); e o público dos diversos espaços expositivos (non-sites), que se relacionam com as obras por meio da fotografia e/ou vídeo.

Assim, as operações poéticas incidem tanto na desconstrução de limites entre públicos quanto em suas classificações de linguagens, substituindo o artigo "ou" - que separa entre uma opção e outra pelo "e", agregador de leituras e camadas discursivas. As fronteiras entre a performance, a intervenção urbana, o vídeo e a fotografia nas poéticas dos trabalhos aqui discutidos ficam borradas.

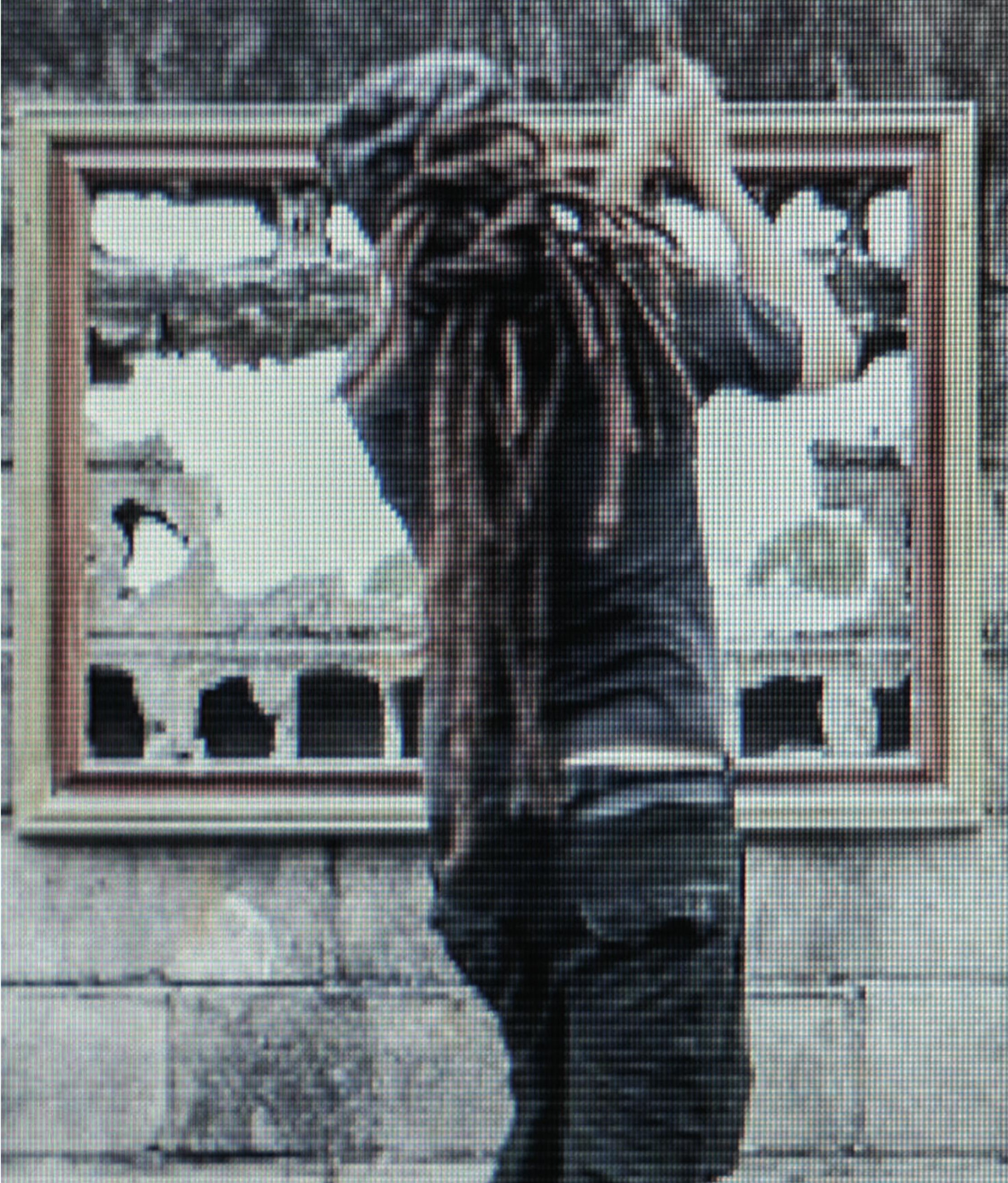




\section{Singularidades}

A transição de linguagens entre Janelas e Paisagem Esculpida Iproduzida com o intuito de saturar o gesto performático no projeto estético - aliada às reflexões geradas em cada trabalho realizado, levou a pesquisa a outro ponto de diferenciação, a partir da nova perspectiva adotada na ação e no registro de Paisagem Esculpida II.

Até então, todos os trabalhos partiam da vista externa e revelava vistas "privadas", propondo uma discussão sobre a ausência de linhas de fugas no espaço urbano efetivada pela presença física dos muros. Em Paisagem Esculpida II, o posicionamento da ação se faz no interior do espaço privado por meio de invasão, intervenção e registro, revelando desta vez a paisagem do espaço público ao invés do espaço privado, abordando outro tipo de experiência urbana: a perspectiva da intimidade.

Essa mudança de eixo traz também um novo aspecto ao trabalho a referência à tradição da pintura de paisagens no Ocidente, cuja origem remonta ao Renascimento, com os fundos das pinturas religiosas que passam a ter paisagens realistas ao invés da cor dourada chapada. Posteriormente, o Romantismo expande as paisagens na tradição pictórica trazendo-a como tema central, consolidando a paisagem como um gênero independente, que o século XIX - com os impressionistas - a transforma em um dos gêneros mais populares da tradição pictórica.

As paisagens pictóricas emolduradas nas paredes trazem também 0 aspecto de expansão e profundidade aos espaços interiores com 0 artifício do "quadro-janela", que abre metaforicamente o ambiente real ao espaço pictórico das obras. As fotografias com as intervenções urbanas, quanto nos non-sites, com as fotografias impressas em papel de algodão.

Com a mudança das operações poéticas e a utilização do vídeo em Paisagem Esculpida I e Paisagem Esculpida II, um efeito similar é produzido, só que agora fazendo alusão a um novo tipo de expansão do espaço, a abertura proporcionada pela tela, mencionada por Paul Virilio:

(...) a primeira janela foi a porta, foi a porta-janela, ou seja, há uma única abertura para os homens, para as coisas, para 0 ar, para a luz. Não deve haver arquitetura sem porta, assim a porta janela é a primeira janela. A segunda janela, a porta que ilumina, que serve apenas para iluminar, para olhar e para arejar, aparece muito tardiamente. Aparece, de início, com o claustro, isto é, com as estreitas aberturas nos locais sagrados, porque, como a luz é assimilada ao divino, devese deixar que 0 raio de luz penetre no espaço. Em seguida, a janela torna-se mais larga, nos castelos dos príncipes, porque os castelos dos príncipes estão cercados de muralhas fortificadas e pode-se abrir, sem riscos, a interioridade da casa. A janela, com seu balcão passa a ser lugar de exibição das mulheres (...). Para 0 camponês a janela continuará bem pequena e não terá, praticamente, utilidade alguma. (...) Na cidade, a janela formará a fachada e continuará a ser um lugar de exibição para as mulheres, para as flores que ali são colocadas, para os lençóis que são instalados como na Feira de Sevilha; é um balcão de teatro, e para estar informado deve-se abrir a janela, pela manhã, e ver o que acontece na rua, se está chovendo, se é dia de feira, se há pessoas passando. A terceira janela é a da televisão. Acorda-se pela manhã e liga-se o botão para ver o que está acontecendo pelo mundo, o tempo que está fazendo etc. (...) Ela é uma abertura sem fachada. Essa abertura dá para a cidade, ela não dá mais para a praça pública, para a rua, para os vizinhos, ela dá para 0 que está além. 0 advento dessa terceira janela é um elemento fundamental e revolucionário da história da arquitetura e da história das cidades (...). (VIRILIO apud BAPTISTA, p. 37) 
18 "0 que se conserva, a coisa ou a obra de arte, é um bloco de sensações, ist é, um composto perceptos e afectos. Os perceptos não

mais são percepções,

são independent

do estado daqueles

que os experimentam:

os afetos não são

mais sentimentos ou

afecções, transbordam

a força daqueles que

são atravessados por

eles. As sensações,

percepções e afectos,

são seres que valem por

si mesmos e excedem

qualquer vivido. Existe

na ausência do homem.

podemos dizer, porque

fixomem, tal como

fixado na pedra, sobre

a tela ou ao longo

das palavras, e ele

próprio um composto de

perceptos e de afectos.

A obra de arte é um se

mais: ela existe em

Os acordes são

afectos. Consoantes

issonantes, os acordes

de tons ou de cores

música ou de pintura.

(DELEUZE. GUATTARI,

1992. p. 193

verdade que toda

E verdade que to

monumento mas o

onumento não é aqui

o que comemora 0

psado, é um bloco de
A utilização do vídeo em Paisagem Esculpida / e Paisagem Esculpida II, além de trazer para ao presente a discussão das "janelas" transformadas em telas televisivas pela "abertura em fachada" na arquitetura contemporânea, também acresce aos trabalhos a possibilidade de novos tipos de "afectos" e "perceptos" conservados nos blocos de sensações ${ }^{18}$ de cada trabalho. (Cf. DELEUZE; GUATTARI, 1992)

A inserção da "imagem-tempo" na pesquisa possibilitou além da ênfase no gesto performático, também agregar variações de intensidades e qualidades conservadas nos registros em vídeo, como: a duração do vento, as variações de luz, as intensidades sonoras entre outros "afectos" e "perceptos" possibilitados pelo transcorrer do tempo nos trabalhos. Pequenas variações marcam grandes diferenças entre as Janelas e as Paisagen Esculpidas que, apesar de discutirem o mesmo tema confluem em direções completamente outras, demonstrando a plasticidade do "devir-pesquisa".

Podemos destacar algumas diferenças visíveis em pequenas variações de "afectos", como: a dança da vegetação com o vento, a movimentação das nuvens no céu, o som das ondas ou do espaço urbano, entre outros. Nelson Brissac, em seu livro Paisagens Urbanas, já havia tocado neste assunto ao aborda as singularidades do cinema em relação à tradição pictórica ao analisar o filme Ordet (1955), de Carl Theodor Dreyer

Por um breve momento, diz Griffith, com a invenção do cinema, deu-se uma aparição: a beleza do vento soprando nas árvores. Algo que não se mostra de imediato, que não se deixa facilmente retratar. Um esplendor que, entretanto, acabaria desaparecendo talvez para sempre - dos filmes.
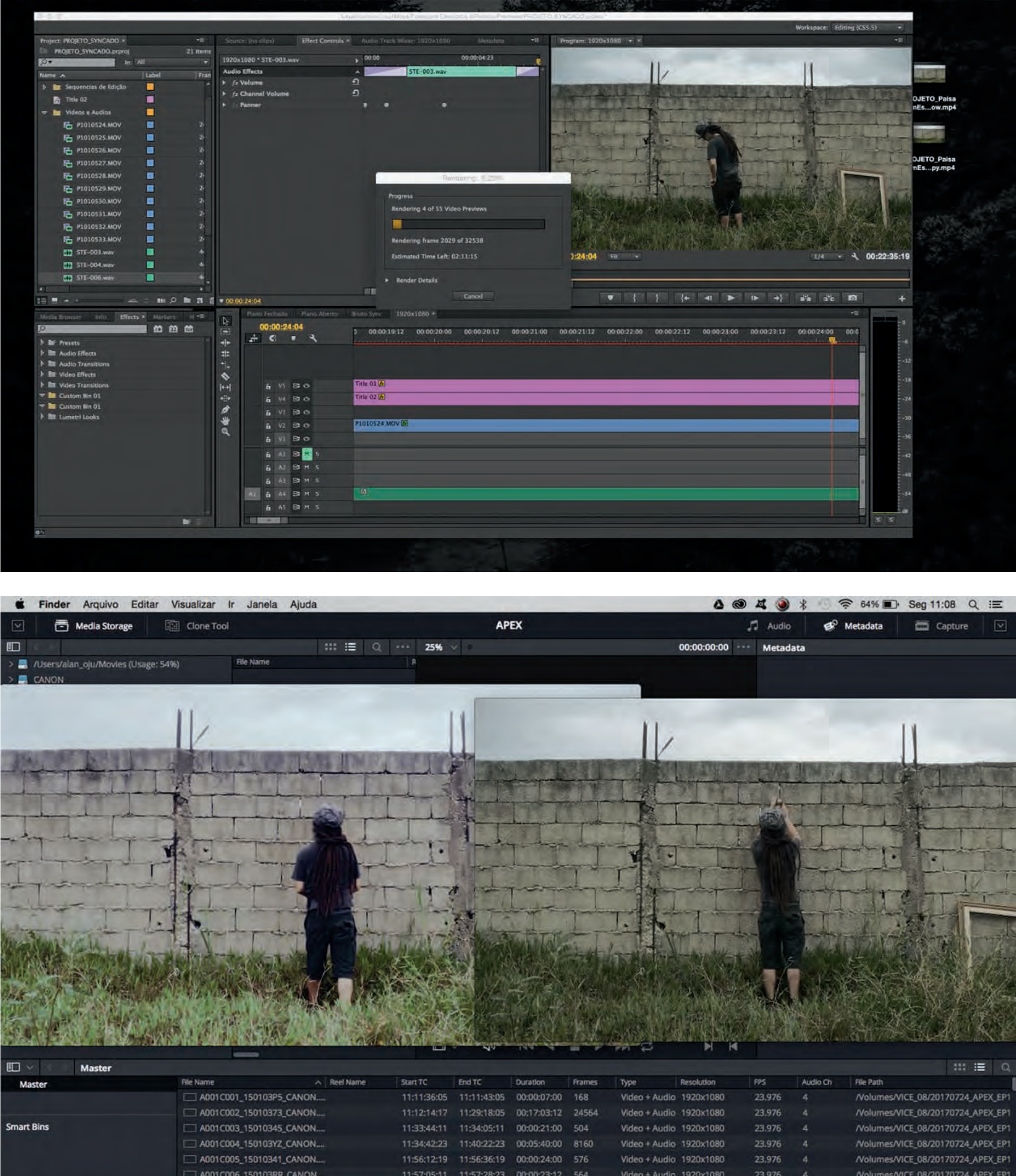

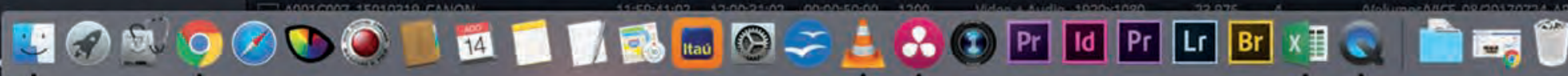


sensações presentes que só devem a si mesmas sua própria conservação, e dão ao acontecimento 0 composto que o celebra. $O$ ato do monumento não é a memória, mas GUATTARI, 1992, p. 198)
A cena - em Ordet, de Dreyer - é inesquecível. Uma casa no campo quase à beira-mar. Ao lado, uma colina recoberta por um trigal. Uma escada conduz ao topo Lá, postos para secar ao sol, estendidos num varal, lençóis brancos tremulam ao vento. Nenhum ruído ecoa na paisagem. Apenas a presença discreta, mas consistente, do vento se faz sentir: aragem que ondulava a relva. Com a mesma força impalpável que o sagrado faz sua aparição na casa. Imagens do que não se pode descrever. Um cinema que faz ver o inefável.

0 invisível não é, porém, alguma coisa que esteja para além do que é visível. Mas é simplesmente aquilo que não conseguimos ver. Ou ainda: é aquilo que torna possível a visão. 0 enigma que a pintura celebra - lembra Merleau-Ponty - não é outro senão 0 da visibilidade. Ela não evoca coisa alguma. Ao inverso, ela dá existência visível àquilo que a visão profana acredita invisível. É, portanto, no limite, 0 visível o que a pintura no faz ver. 0 que nos faz ver mais do que vemos - a árvore ressequida que, à noite, é um espectro - e também o que não vemos ao ver - o intervalo entre as árvores, o vento. (PEIXOTO, 1996, p. 15)

Por meio da relação que Nelson Brissac faz entre diferenças e correspondências do cinema com a pintura, também podemos criar "painéis" inspirados no Atlas Mnemosyne, de Aby Warburg, e agrupar Ordetà Paisagem Esculpida II, assim como também podemos expandir tais relações a um grande grupo de obras pictóricas da tradição da pintura de paisagens em que elementos qualitativos e intensivos coincidem e simultaneamente diferenciam-se, como as pinturas românticas de Caspar David Friedrich, que coloca seus personagens inseridos em vastas paisagens e dá a sensação de suspensão do tempo, ou às obras da tradição inglesa de paisagens do século XVIII, com John Constable e suas paisagens panorâmicas e Estudos de nuvens; podemos ainda estender ao movimento de mares e luzes nas telas de William Turner. Ou mesmo trazer tais correspondências ao século XX, com as obras surrealistas de René Magritte, que coloca em questão a própria narrativa da pictórica.

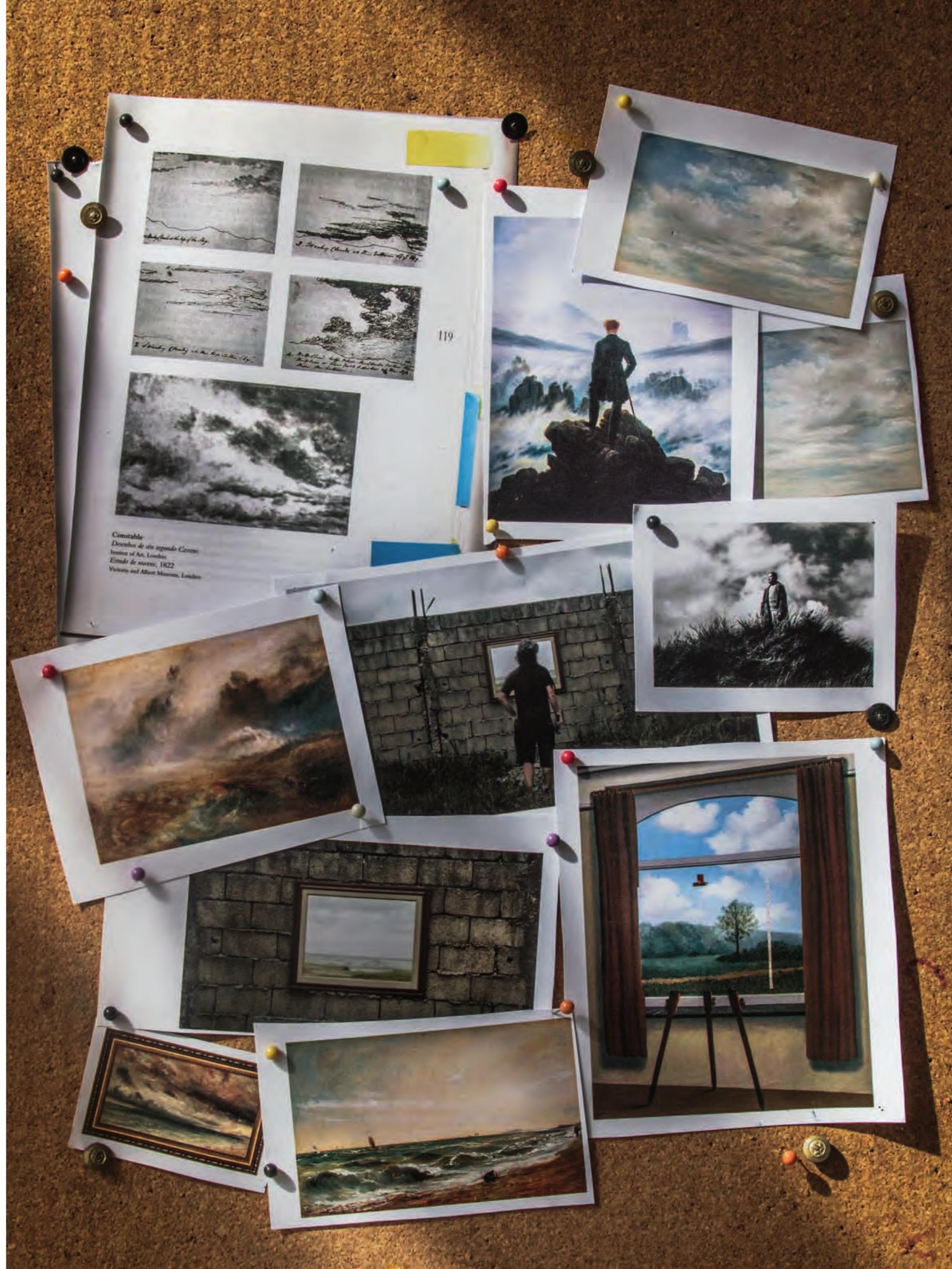




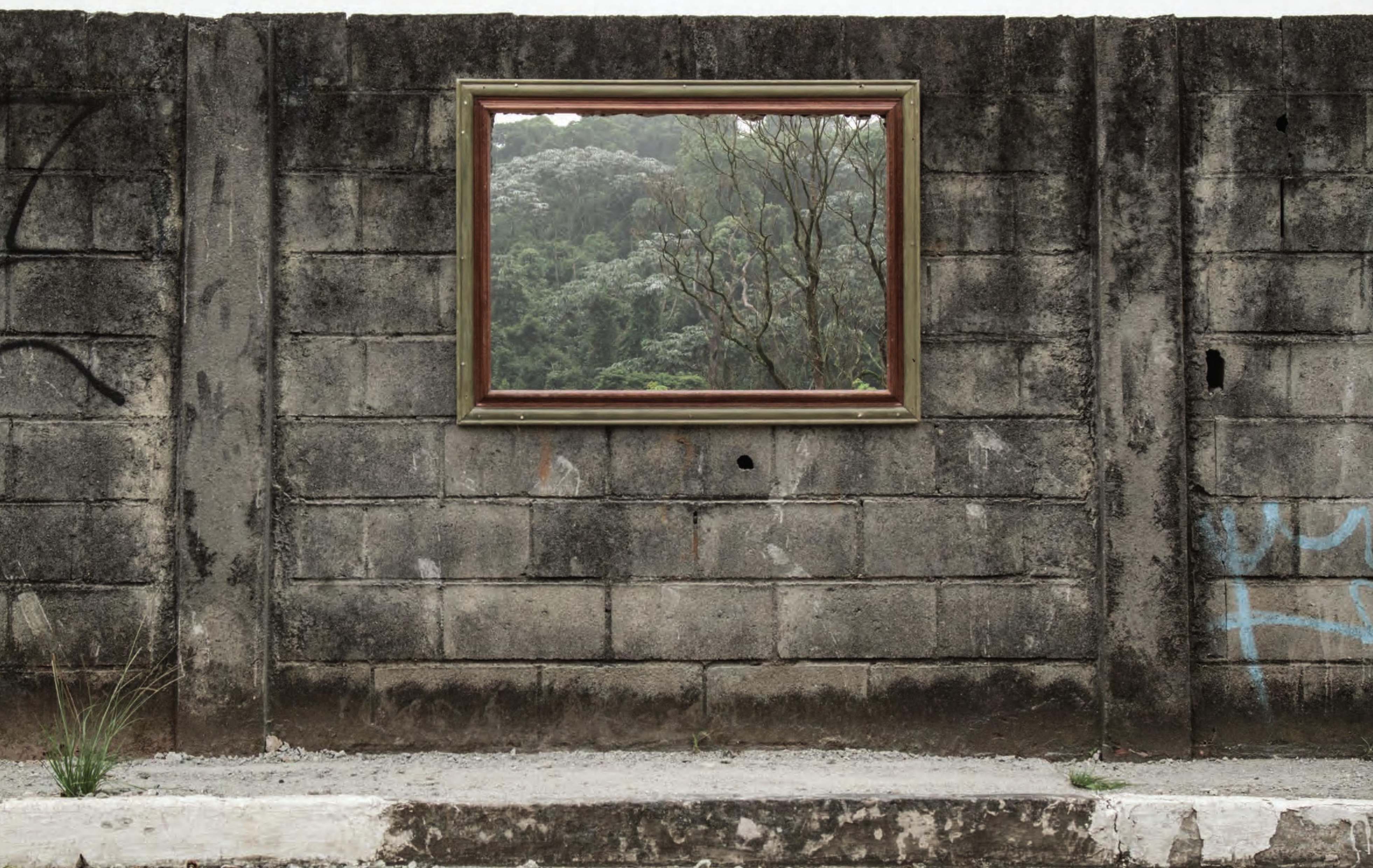




\section{Paisagens e espaços}

0 conceito de paisagem, que a tradição pictórica Ocidental ajudou a formular, tem seus primórdios na Antiguidade, nos afrescos parietais dos pátios de Pompéia, onde representações de campos abertos, pássaros, vegetações, águas e flores compunham as pinturas. Também podemos encontrar na literatura Antiga, vestígios da noção de paisagem nas odes de Vírgilio, que além de enaltecer a vida "rústica" em termos morais, também "extraem uma poética da terra e exprimem 0 prazer de contemplá-la". (BARTALINI, 2008, p.1)

Embora possamos encontrar indícios de "paisagem" no Império Romano, naquela época ainda não existia uma palavra para designá-la. 0 termo "paisagem" ao qual conhecemos hoje tem origem na era moderna, quando a palavra surge em diversos idiomas. A etimologia da palavra em português, por exemplo, advém do francês paysage, sendo que, em seu radical também encontramos a palavra francesa pays, que dá origem a palavra portuguesa "país". Ambas palavras possuem a raiz latina pagus, que alguns dicionários de latim-português traduzem como: campo, aldeia ou país.

Sendo a acepção da palavra paisagem empregada pelo senso comum como algo que corresponde à visualidade e suas representações, ao relacionarmos o sentido visual à etimologia da palavra em português, nos aproximamos de significados políticos e administrativos. Já a palavra inglesa landscape muito utilizada nas referências desta pesquisa, lança o termo estão disponíveis ao olhar. Landscape é uma palavra que advém do alemão Landschaft, cuja raiz Land Shaffen não possui tradução em outros idiomas, no entanto, alguns especialistas aproximamna ao sentido de "criar terra". Assim, o termo inglês landscape traz uma compreensão também cultural para paisagem, ao associar a terra a seus habitantes.

À medida que incorporamos, na atualidade, ambos os sentidos ao termo "paisagem" - principalmente a relação cultural que nele se incute -, ficamos diante de uma noção que se aproxima do espaço geográfico, e por isso, se torna necessário distinguir os conceitos de "paisagem" e "espaço". Segundo o geógrafo Milton Santos, um espaço é um sistema de ações e objetos que confluem para transformar o meio, seja ele natural ou social; desse modo o espaço é composto pelas formas espaciais acrescidas da vida que as anima. Enquanto paisagem é, para o geógrafo, "o conjunto de formas que, num dado momento, exprimem as heranças que representam as sucessivas relações localizadas entre homem e natureza" (SANTOS, 1996, p. 103). 0 autor prossegue a distinção:

A paisagem se dá como um conjunto de objetos reais-concretos. Nesse sentido a paisagem é transtemporal, juntando objetos passados e presentes, uma construção transversal. 0 espaço sempre presente, uma construção horizontal, uma situação única. Cada paisagem se caracteriza por uma dada distribuição de formas objetos, providas de um conteúdo técnico específico. Já o espaço resulta da intrusão da sociedade nessas formas-objetos. Por isso, esses objetos não mudam de lugar, mas mudam de função, isto é, de significação, de valor sistêmico. A paisagem é, pois, um sistema material e, nessa condição, relativamente imutável: o espaço é um sistema de valores, que se transforma permanentemente. 
19 "A nossa época talvez seja, acima de tudo, a época do espaço. Nós vivemos na época da simultaneidade: nós vivemos na época da justaposição, do próximo e do longínquo, do ladoa-lado e do disperso. Julgo que ocupamos um tempo no qual nossa experiência do mundo se assemelha mais a uma rede que vai ligando pontos e se intersecta do que propriamente a uma vivência que se vai enriquecendo com 0 tempo" (FOUCAULT, 1998, p. 1). Entre outros exemplos descritos $p$ or Foucault estão o colégio interno e o serviço militar, que configuram as "heterotopias de crise", em que indivíduos são levados a lugares específicos em determinada tipo de heterotopia advem das sociedades primitivas, em que mulheres menstruadas ou gravidas, idosos, adolescentes etc. eram separados do grupo e levados para ou sagrados. As prisões, au sagrados. As prisóes, hospitais psiquiátricos correspondem às

onde os indivíduos que

não estão de acordo

com determinados
0 espaço, uno e múltiplo, por diversas parcelas, e através do seu uso, é um conjunto de mercadorias, cujo valor individual é função do valor que a sociedade, em um dado momento, atribui a cada pedaço de matéria, isto é, cada fração da paisagem.

0 espaço é a sociedade, e a paisagem também o é. No entanto, entre espaço e paisagem o acordo não é total, e a busca desse acordo é permanente; essa busca nunca chega a um fim. (SANTOS, 1996, p. 103)

A partir da leitura de Milton Santos, podemos distinguir paisagem e espaço nos trabalhos Paisagem Esculpida I e Paisagem Esculpida II. 0 ato da intervenção urbana, por exemplo, se faz no espaço, ao passo que, ao abrir a fenda no decorrer da ação performática, o que se torna visível no interior da moldura são paisagens "naturais": uma pequena reserva de mata Atlântica na cidade de São Paulo, em Paisagem Esculpida I, e o oceano Atlântico em Paisagem Esculpida II. Paisagens esculpidas no espaço urbano pela subtração parcial do muro, paisagens que se sobrepõem no vídeo, espaço-paisagem para experiência do espectador transeunte urbano.

Podemos também ampliar a discussão de espaço na pesquisa a partir de outra perspectiva, com o conceito de heterotopia proposto por Michel Foucault. 0 espaço heterotópico se caracteriza como um espaço fechado, construído com a finalidade de propor um espaço neutro e especializado, atuando como um contraespaço em relação a sua exterioridade: "as heterotopias possuem sempre um sistema de abertura e fechamento que as isola em relação ao espaço circundante" (FOUCAULT, 2013, p. 26). 0 autor ainda afirma que o nosso tempo pode ser considerado como a "época dos espaços", pois nunca na história existiram tanto espaços e contraespaços coexistindo simultaneamente ${ }^{19}$. Para exemplificar tais espaços

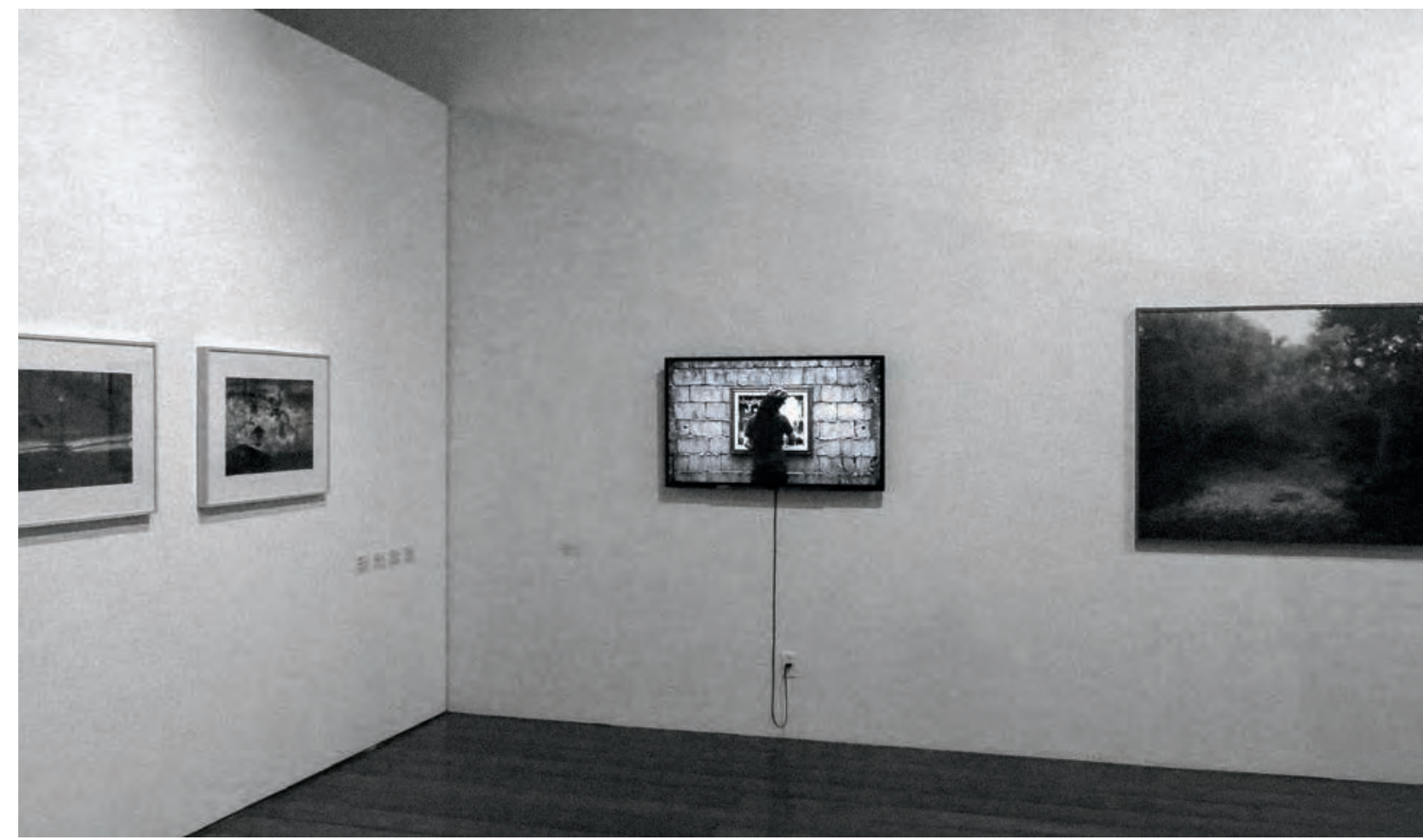

especializados, neutros e fechados, citamos alguns que 0 padrões normais são próprio autor nos fornece, entre tantos outros:

Em geral, a heterotopia tem como regra justapor em um lugar real vários espaços que, normalmente, seriam ou deveriam ser incompatíveis. 0 teatro, que é uma heterotopia, perfaz no retângulo da cena toda uma série de lugares estranhos. 0 cinema é uma grande cena retangular, no fundo da qual, sobre um espaço de duas dimensões, projeta-se um novo espaço de três dimensões. Porém, o mais antigo exemplo de heterotopia seria talvez o jardim, criação milenar que tinha certamente no Oriente uma significação mágica. (FOUCAULT, 2013, p.24)

A relação que fazemos com os espaços heterotópicos de Foucault nesta pesquisa, por meio dos trabalhos Janelas, Paisagem Esculpida I e Paisagem Esculpida I/ se efetua principalmente pela inserção das molduras no espaço público. Ao deslocar a moldura de seus espaços habituais e fazendo-a conviver com a rua, demove-se também toda a carga simbólica do dispositivo consolidado pela tradição pictórica. Até o século XIX a própria moldura bastava como elemento diferenciador, sob seus levados. Foucault

também cita outro tipo de espaço heterotópico que está relacionado à heterocronia; esse tipo inclui os museus e bibliotecas, pois arquivam documentos e obras de diversos tempos. Em outro contexto, também relacionado a heterocronia, estão os festivais, como espaços de duração passageira. As galerias de arte enquadram-se no que 0 autor nome de "heterotopia de compensação", em que se cria "um espaço outro, real, tão perfeito. meticuloso e organizado em desconformidade com os nossos espaços 1998, p. 5). 
medieval. 0 mundo exterior não deve entrar, de modo que as janelas geralmente são lacradas. As paredes são pintadas de branco. 0 teto torna-se a fonte de luz. 0 chão de madeira é polido, para que você provoque estalido austeros ao andar, ou acarpetado, para que você ande sem ruído. A arte é livre, como se dizia, "para assumir vida própria". (0`Doherty, 2002, p. 3-4)

Os trabalhos desta pesquisa, produzidos em ambientes extramuros, atuam em oposição à imagem proposta por Bryan O’Doherty - da galeria modernista constituída sob preceitos assépticos e artificiais - e buscam, portanto, produzir alternativas de espaços para a arte em contraposição ao ideário sacro e elitista do cubo branco, aproximando a arte da vida urbana.

Entretanto, também cabe-nos dizer que a atitude da produção extramuros não deve ser tomada como uma negação pueril do espaço das galerias. Ao promover um trânsito rua-galeria para os trabalhos, visa-se a retomada de um debate crítico já iniciado nas décadas de 1960 e 70 e à utilização sagaz de tais espaços na atualidade, consciente das contradições implícitas. Desse modo a inserção em tais circuitos também é tida como elemento de potencialização das questões propostas pelos trabalhos.

Tanto em Janelas quanto em Paisagem Esculpida I e Paisagem Esculpida II, esse diálogo entre espaços é produzido em princípio pelo deslocamento da moldura para o espaço público, invertendo o trânsito "habitual" de elementos dos sites para os non-sites nas operações poéticas, levando a discussão sobre heterotopias primeiramente ao espaço urbano. Para posteriormente retornar aos contraespaços em forma de projetos estéticos, os trabalhos, além de aludir às discussões já introduzidas pela moldura, produzem diálogos entre non-site e site, atuando como contradispositivos que abrem a galeria para que questões do espaço público invadam o cubo branco.

Nessa direção, torna-se importante referirmo-nos a Gordon MattaClark nesta pesquisa, pois suas operações poéticas rompiam com as noções de interior e exterior, público e privado, cheio e vazio. Aqui citaremos apenas um de seus trabalhos: Conical Intersect (1975), novamente fazendo um uso extraordinário das correspondências "warburgianas". Produzido a convite de Georges Boudaille para a IX Bienal de Paris, o trabalho é um exemplo que sintetiza inúmeras das questões que viemos abordando até aqui a partir das Paisagens Esculpidas. Em Conical Intersect, Matta-Clark opera um corte de formato cônico na arquitetura de dois apartamentos, rasgo cujo eixo central estava a 45 graus em relação à rua e sua base compunha um vazio de 4 metros de diâmetro na fachada do prédio. A extremidade menor do corte cônico penetrava até 0 segundo apartamento. 0 público pôde acompanhar o processo performático da construção do trabalho a partir da rua; assim como, quando finalizado, pôde adentrar na instalação que unia, pelo vazio, os vários ambientes dos dois apartamentos. Ao final da Bienal, o público também pôde assistir à destruiçã̃o da obra, com a demolição (já prevista) do prédio ${ }^{20}$. 0 trabalho se deu no bairro de Les Halles, loca histórico onde se situa o primeiro arrondissement de Paris. Um dois apartamentos "cortados", inclusive, foi habitado por um oficial da corte de apelações, ou seja, o prédio era testemunha do Antigo Regime e estava então sendo demolido para "modernizar" a região. Nas adjacências do edifício, estava sendo construído na mesma época o Centre Georges Pompidou.

A questão do site specific era vital na poética de Matta-Clark pois era sobre as tensões dos espaços que 0 artista trabalhava, como ele mesmo dizia:
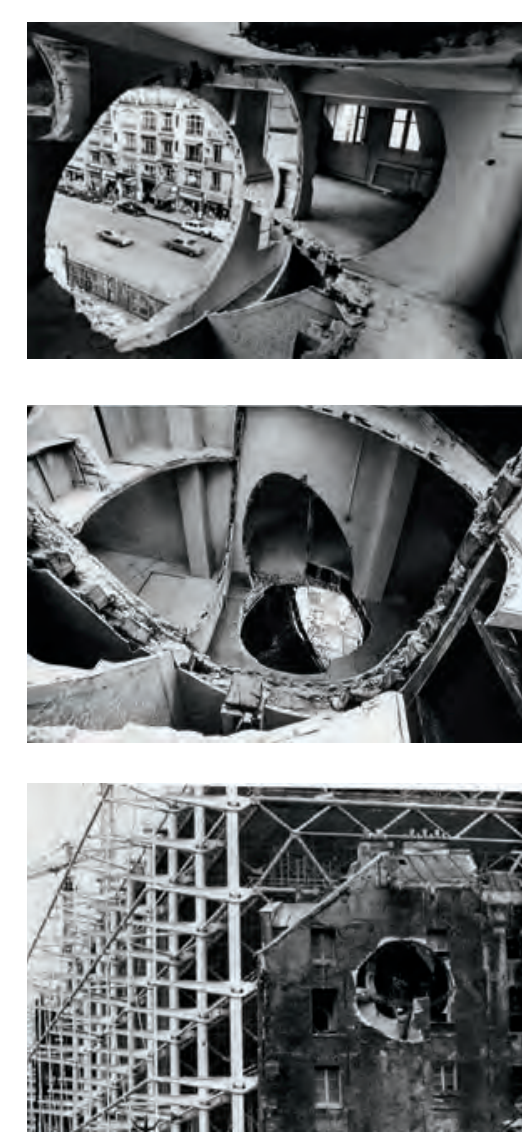

20 Gordon Matta-Clark \& Bruno de Witt. Conical Intersect. Paris, 1975. vimeo $00 \mathrm{~m} / 106117205$ 
Atualmente, meus interesses tendem ao metamórfico. 0 metamórfico consiste em literalmente alterar a composição de algo por meio da pressão externa ou, mais frequentemente, em liberar as pressões de transformação internas e ocultas. Todos os lugares possuem alguma ambiguidade. Não é preto no branco. 0 espaço é mais que a manipulação "estética" das formas. É essa ambiguidade que precisa ser liberada, esclarecida, amplificada e incrementada, como quiser. Isso me leva a situações que, aos olhos da maioria das pessoas, são incompreensíveis e talvez absurdas, mas que para mim são perfeitamente razoáveis". (MATTA-CLARK apud CUEVAS, 2010, p. 168)

Em Conical Intersect, Gordon Matta-Clark visava explorar as tensões existentes entre a necessidade de preservação do patrimônio histórico e a destruição destes locais como prérequisitos para o progresso. 0 trabalho não apenas permitia ao público ver 0 exterior e 0 interior ao mesmo tempo, mas também escancarava problemas do espaço urbano, sobretudo a memória da cidade sob constante ameaça de desaparecer.

Ao abrir arquiteturas com seus cortes, Matta-Clark criticava ironicamente também a arquitetura modernista ao subtrai pedaços de arquiteturas em suas obras, permitindo desse modo a entrada de ar e luz aos recintos e remetendo às características da arquitetura modernista que, ao empregar materiais translúcidos e vãos livres em seus espaços, permitem a entrada de ar e luz natural aos interiores.

A poética de Matta-Clark converge com esta pesquisa em diversas questões, como por exemplo: na reflexão sobre o espaço urbano e as ideologias presentes tanto nas construções como nos planos gestores do espaço público; na desconfiança do "progresso", que coloca o valor de troca como fundamento em detrimento do valor de uso e das memórias dos lugares; na investigação das tensões específicas de cada espaço onde escolhe intervir - os sites specifics; na crítica de espaços ultrarracionalizados, como as heterotopias do "cubo branco"; nas esculturas por subtração e, por fim, no fato de seus trabalhos produzidos na década de 1970 chegar até o presente nos pedaços coletados dos sites, ou apenas por registros em vídeos e fotografias. Matta-Clark não apenas desfaz espaços, mas também limites entre a performance a escultura, a intervenção e os registros em mídias. Portanto citá-lo aqui, é dar créditos à importância que seu legado tem nesta pesquisa

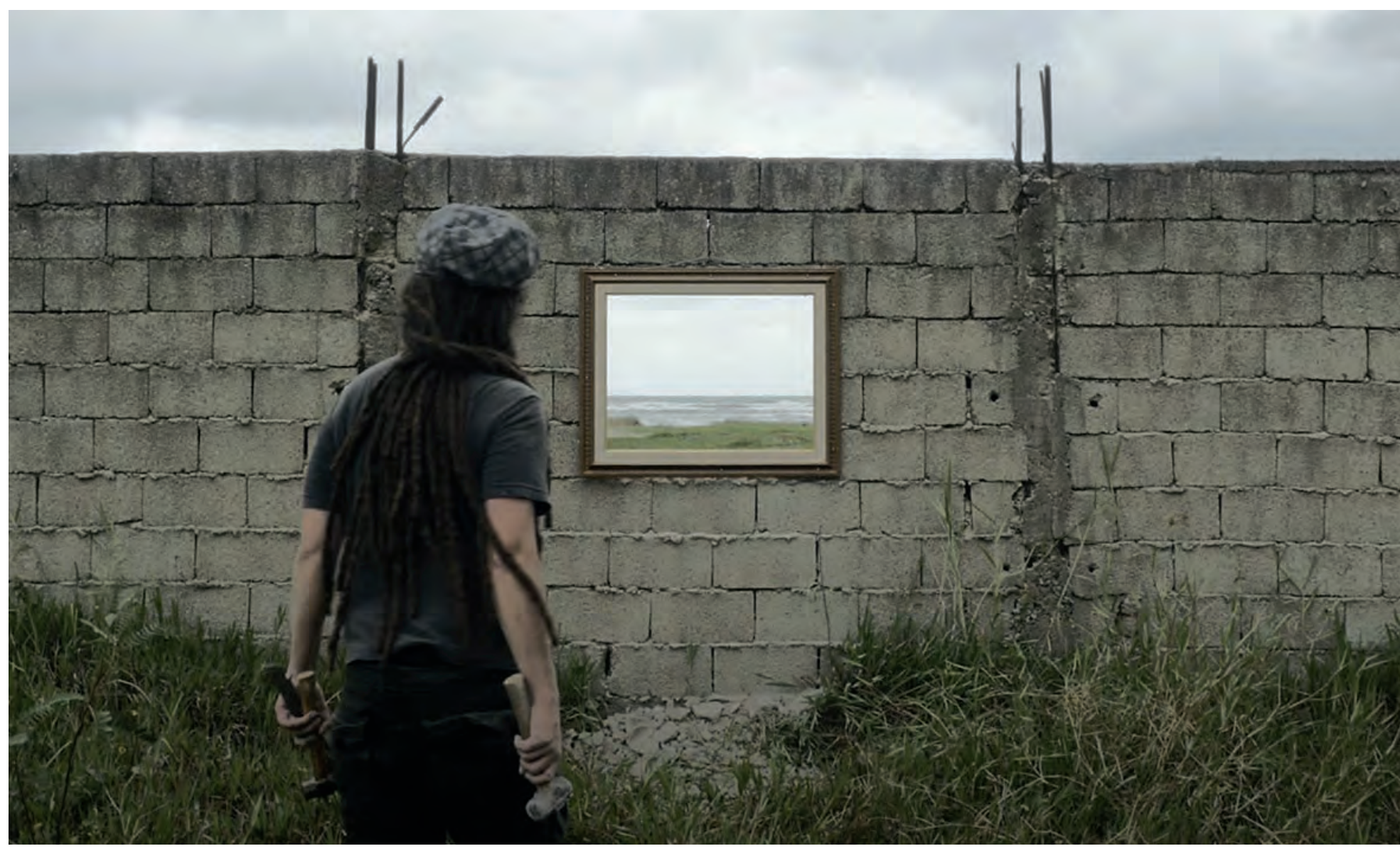



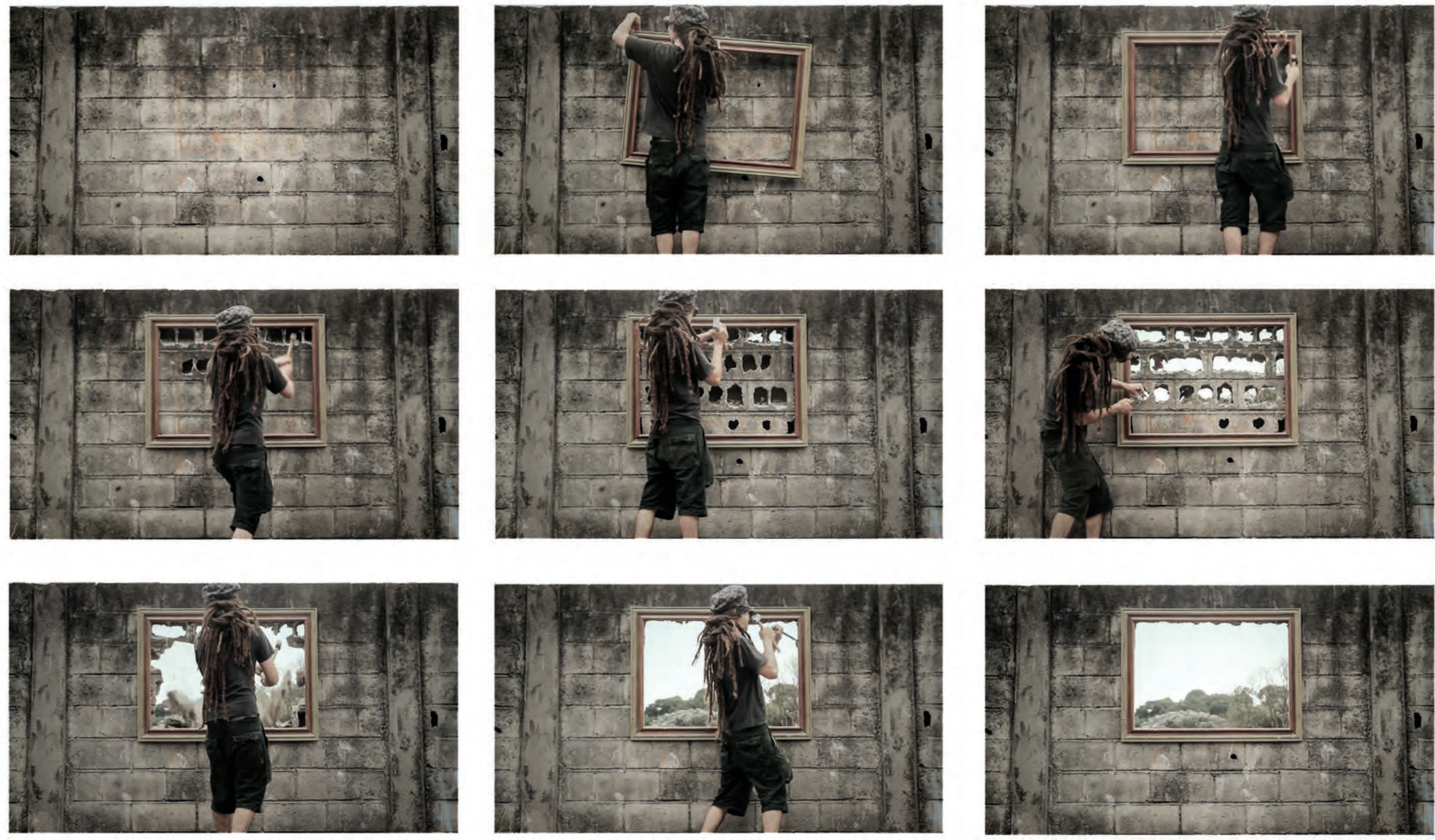


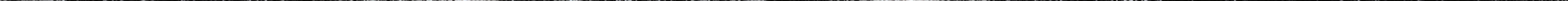




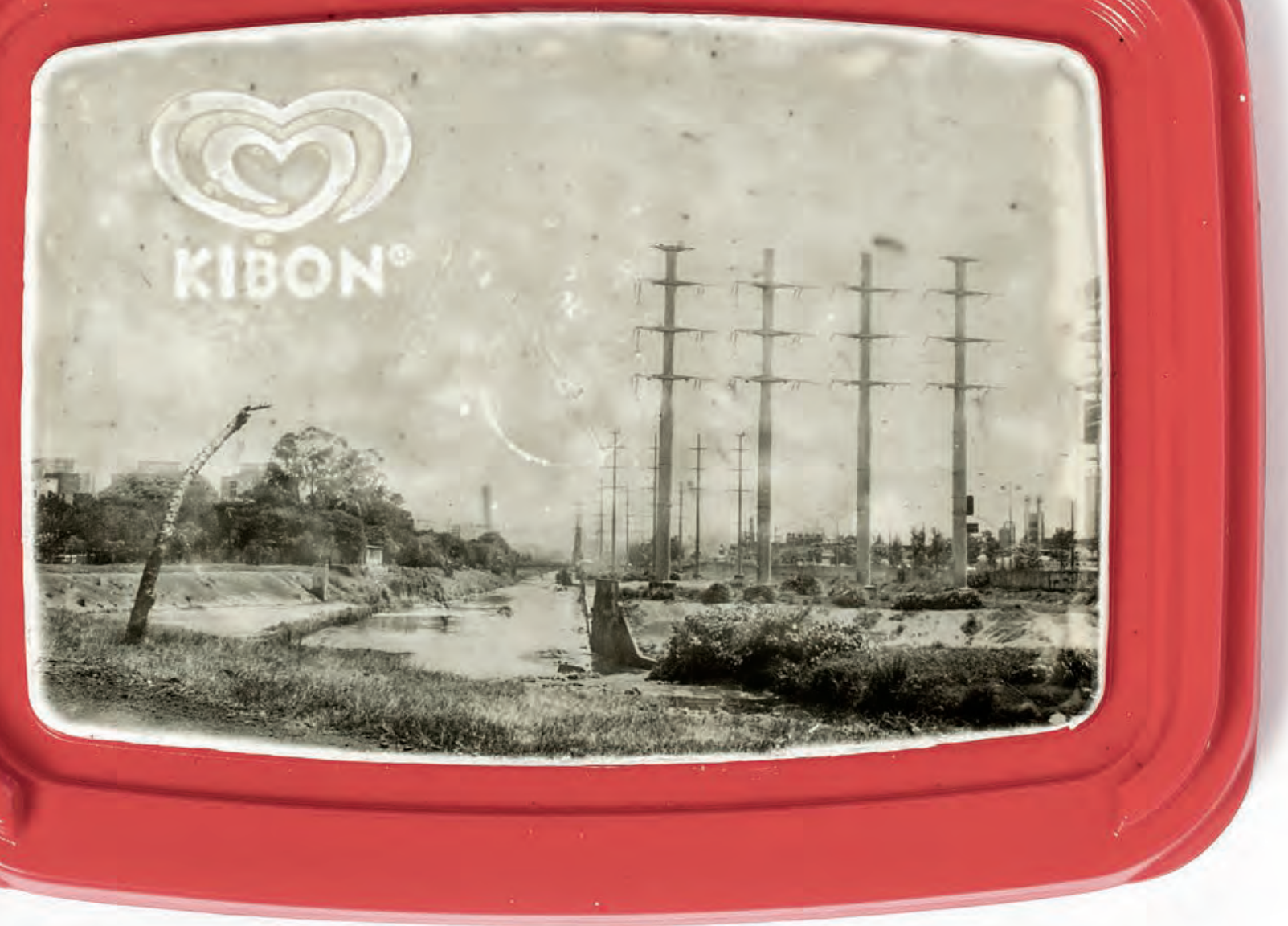



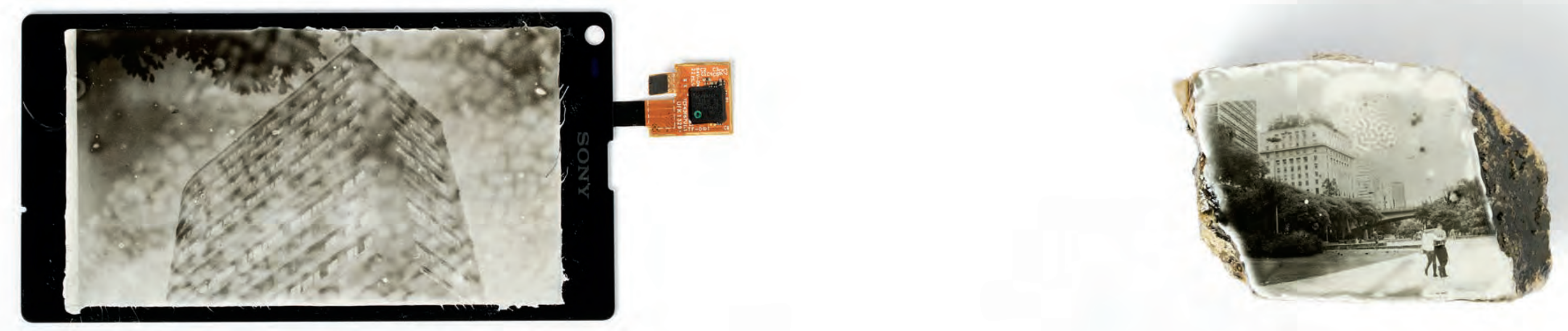


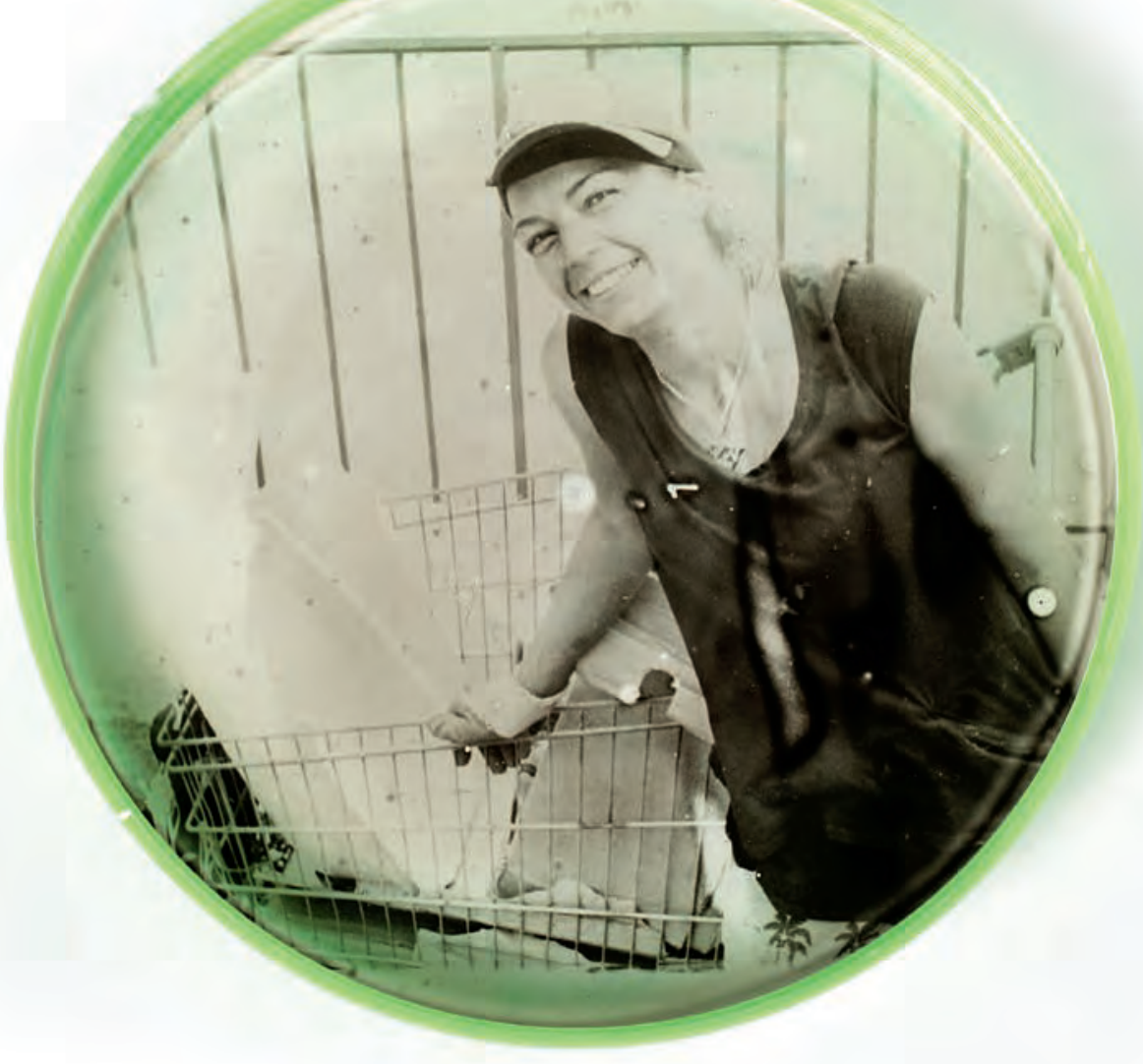



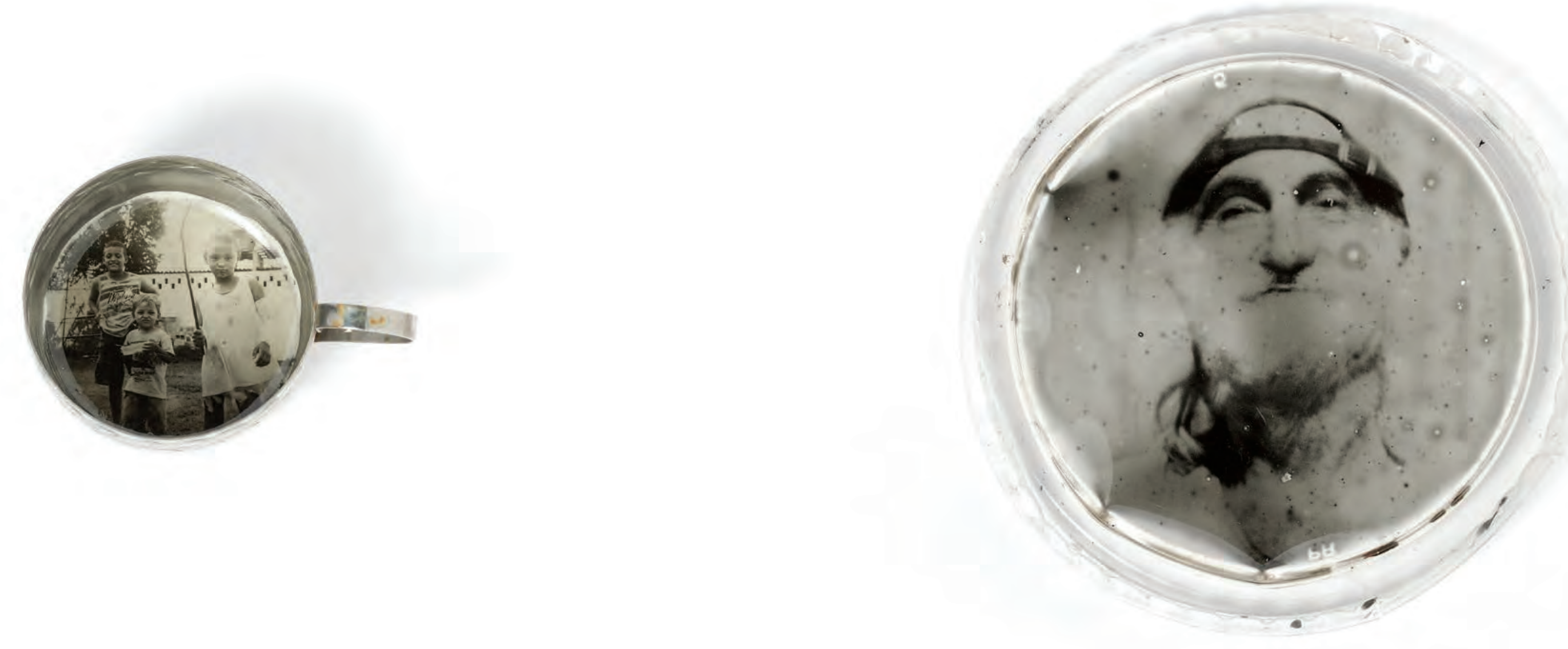

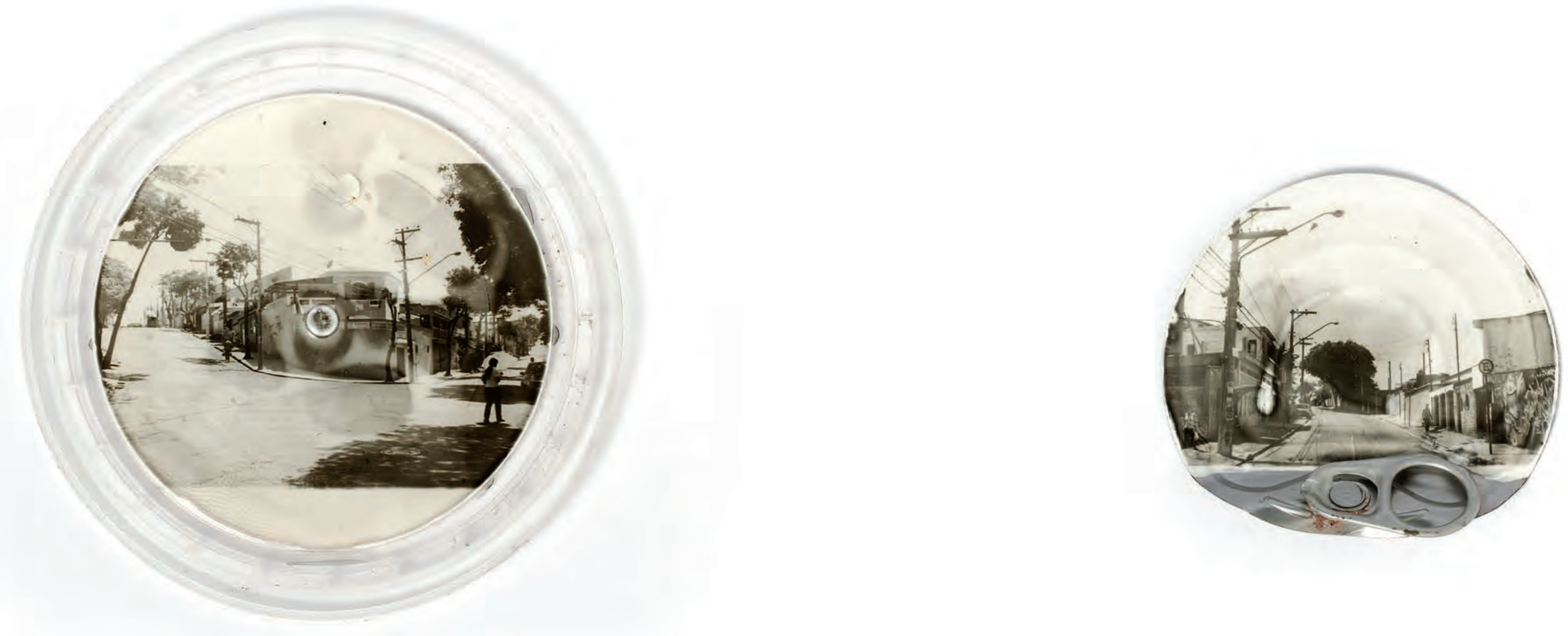

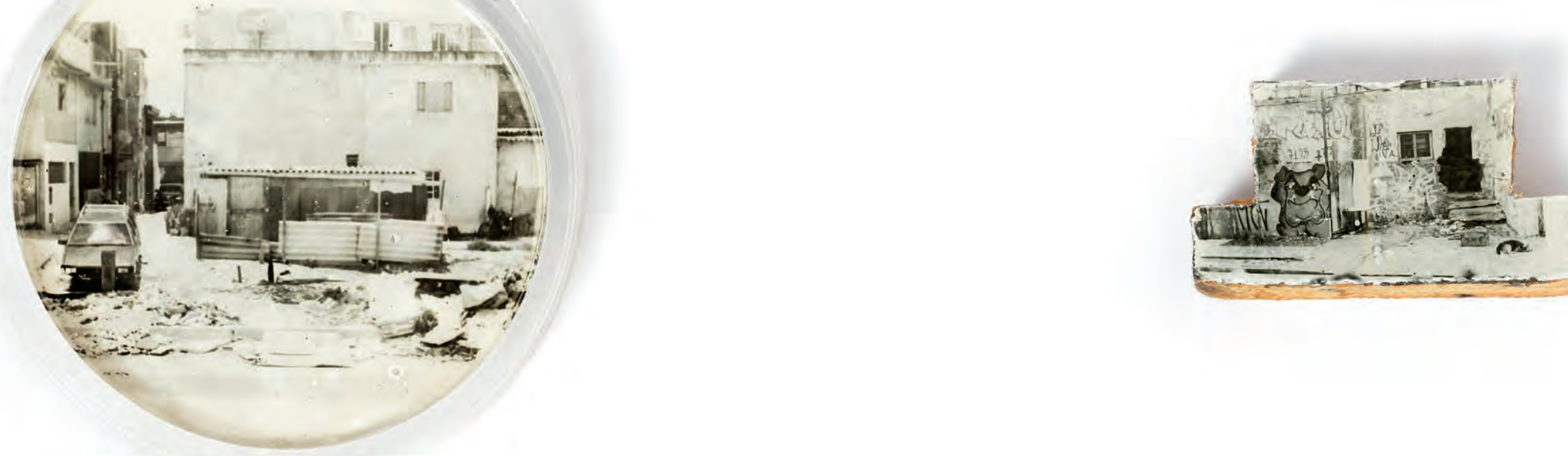

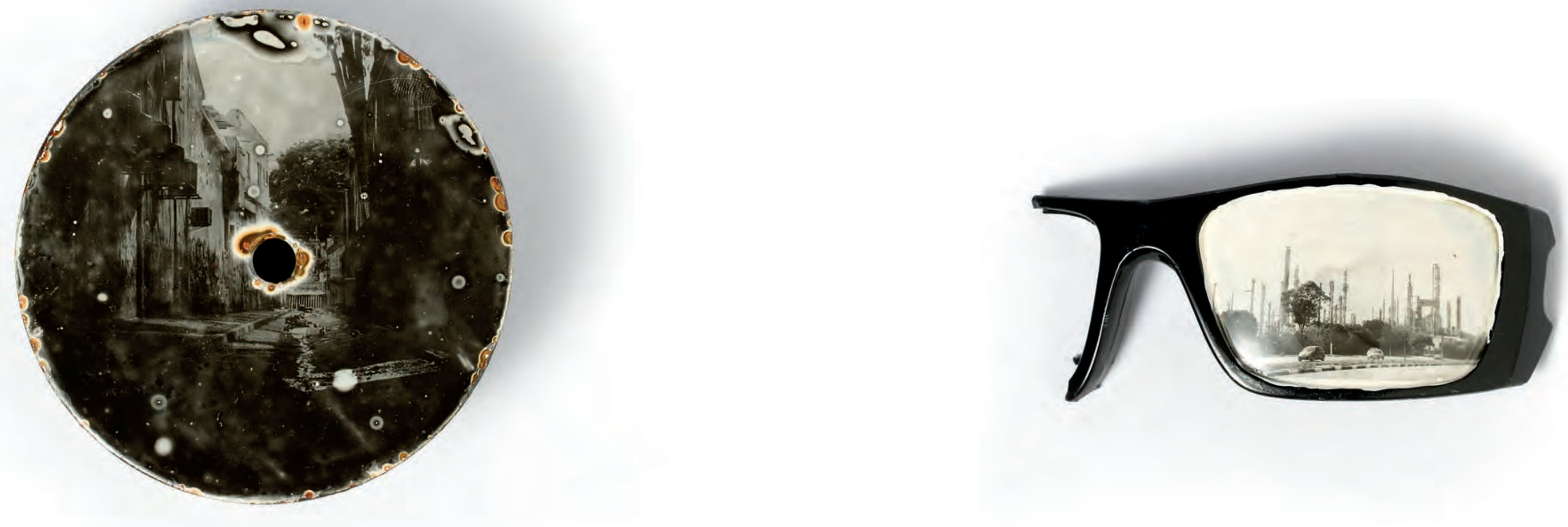
Nusere

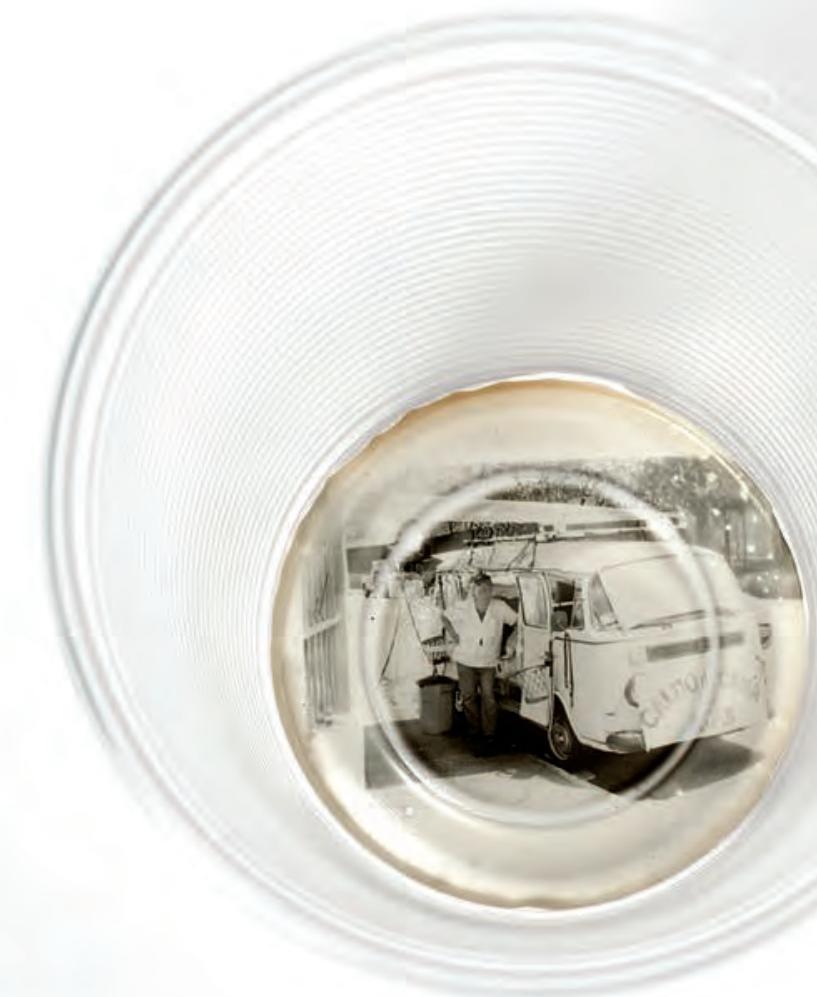




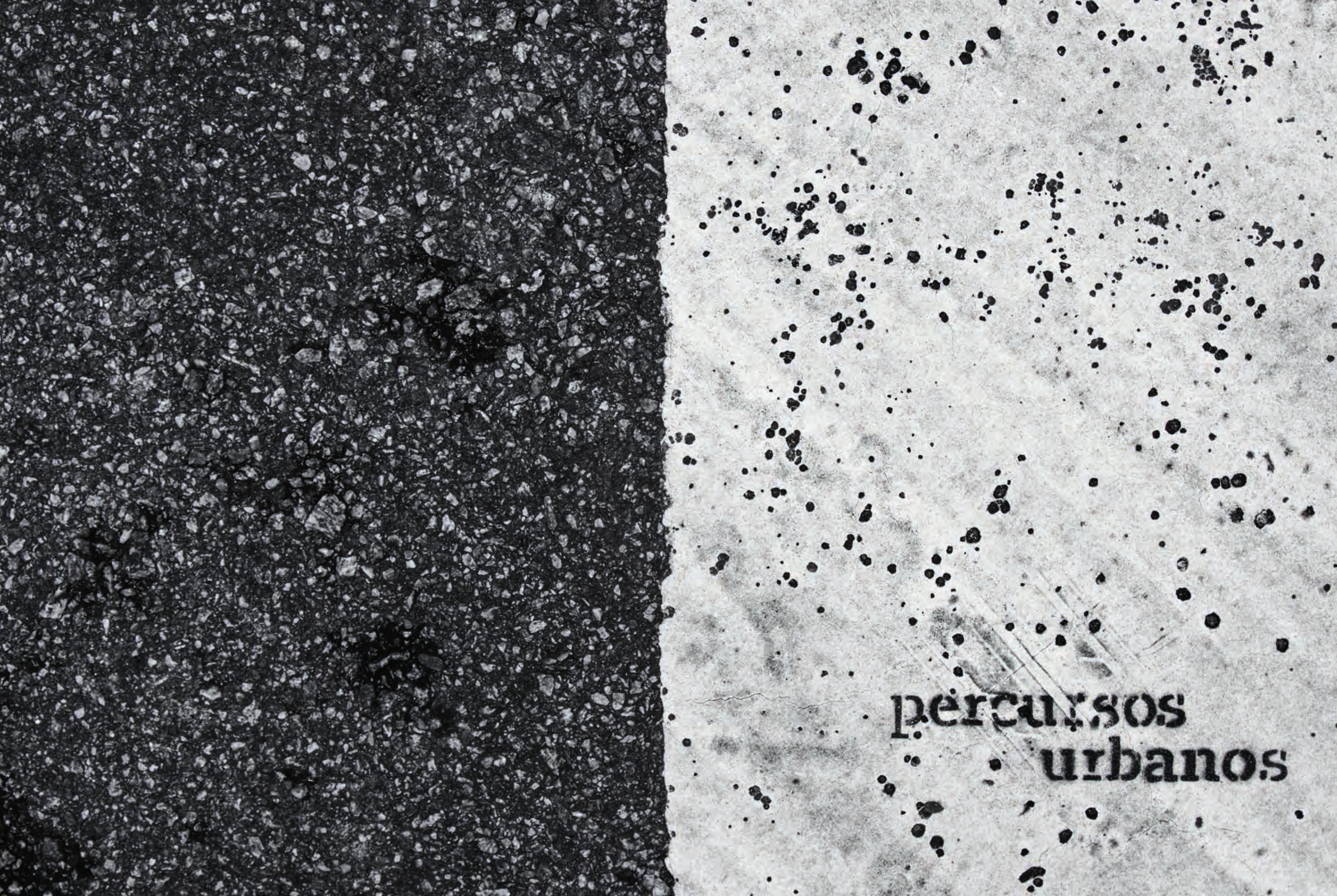


Primeiros passos

Até aqui, os rumos desta pesquisa concentraram-se em discutir a relação entre sujeito e paisagem a partir de intervenções urbanas registradas em vídeo e fotografia. A partir da reflexão obtida nos trabalhos anteriores - sobretudo, o modo pedestre de deslocamento para produzi-los -, o próprio caminhar converteuse em elemento poético, devido sua potência expressiva, em novas ações e trabalhos artísticos. Com isso, pretendemos nas próximas linhas fazer um breve histórico de como o caminhar foi sendo incorporado, como prática, na história da arte, com 0 intuito de elencar algumas similitudes e diferenças com as investigações artísticas realizadas nesta pesquisa.

0 caminhar como prática estética já foi objeto de trabalho de inúmeros artistas ${ }^{21}$ ao longo do século $X X$, pesquisas que vinham na esteira do processo de desmaterialização da obra de arte, intensificada na segunda metade do século, quando artistas passam a tecer relações mais diretas com o mundo, levando a arte para ambientes extramuros em ações realizadas no espaço urbano e no campo, nas quais o próprio corpo do artista torna-se dispositivo artístico em determinados contextos efêmeros.

0 poeta Charles Baudelaire foi um dos que primeiramente avistou, na ação ordinária do caminhar, singularidades que permitiam a compreensão de um mundo em profunda mudança no contexto europeu do século XIX. Em seu artigo "0 pintor da vida moderna", ele apresentou a figura do flâneur como sujeito que se perde em meio às multidões, onde passa desapercebido

21 A lista de artistas que utilizaram o caminhar como prática estética no século XX é enorme. Aqui, citaremos apenas um recorte de nomes, com vistas a apresentar algumas referências precursoras. No Brasil, três nomes se destacam: Flávio de Carvalho com a Experiência n.2 11931 Hélio Oiticica com Delirium Ambulatorium (1978) e Artur Barrio com o trabalho/

processo 4 dias, 4 Noites (1970). Já no âmbito

internacional, destacamse: Vito Acconci com Following Pieces (1969) Richard Long $\operatorname{com} A$ Line Made by Walking (1967) - obra já citada no capítulo anterior, Robert Smithson com Monuments of Passaic (1967), Francis Alỳs com Sometimes Making Something Leads to Nothing (1997) e Francesco Jodice com
The Secret Traces (1999). 
internationale situationniste perspectiva sobre o caminhar como prática estética. Opunhamse às deambulações surrealistas por considerarem o espaço da cidade como o lugar ideal para construção de novos comportamentos que levariam seus praticantes a construir uma relação de apropriação do espaço por meio da experiência do território objetivo das cidades, em contraposição ao lócus subjetivo-inconsciente das deambulações surrealistas.

Por meio da prática das derivas, os situacionistas almejavam restabelecer o sentido de pertencimento aos lugares e desenvolver em cada praticante um potencial ativista em contraposição a lógica da sociedade do espetáculo que denunciavam.

A Internacional Situacionista (IS) - grupo de artistas, pensadores e ativistas - lutava contra o espetáculo, a cultura espetacular e a espetacularização em geral, ou seja, contra a não participação, a alienação e a passividade da sociedade. 0 principal antídoto contra 0 espetáculo seria seu oposto: a participação ativa dos indivíduos em todos os campos da vida social, principalmente no da cultura. 0 interesse dos situacionistas pelas questões urbanas foi uma consequência da importância dada por estes ao meio urbano como terreno de ação, de produção de novas formas de intervenção e de luta contra a monotonia, ou a ausência de paixão, da vida cotidiana moderna. (JACQUES, 2003, p. 13)

Os situacionistas criaram o Urbanismo Unitário, uma teoria urbana crítica ao urbanismo hegemônico e ao planejamento generalizado da vida urbana, que tinha nos arquitetos e urbanistas modernistas dois de seus principais alvos, pois estes agiam, segundo eles, de acordo com o pensamento cartesianocapitalista. Raoul Vaneigem escreve, em "Comentários contra 0 urbanismo", publicado no número 6 da Revista da Internacional Situacionista, de 1961, um texto repleto de ataques:
Se o planejador não pode conhecer as motivações comportamentais daqueles a quem ele vai proporcionar moradia nas melhore condições de equilíbrio nervoso, mais vale integrar desde já o urbanismo no centro de pesquisas criminológicas. (VANEIGEM apud JACQUES, 2003, p. 19)

0 autor prossegue, em outro texto da mesma revista, afirmando que 0 urbanismo não existe e não passa de uma "ideologia"22, pois visa construir necessidades pautadas no consumo, sendo a cidade encarada apenas como mais uma mercadoria. Em contraposição a esta realidade que denunciavam, os situacionistas constroem todas as suas teorias e práticas, almejando construir situações revolucionárias no cotidiano, e, a partir da negação da sociedade do espetáculo, propõem os conceitos de deriva e psicogeografia.

A deriva, segundo Guy Debord, constitui-se em um comportamento lúdico-construtivo, por meio da passagem rápida por diversos ambientes; um comportamento experimental de jogo no espaço urbano e que possui duração finita. Já a psicogeografia seria sua coextensão, definida como o "estudo dos efeitos do meio geográfico, consciente planejado ou não, que agem diretamente sobre o comportamento afetivo dos indivíduos" (REVISTA I.S N.01 apud JACQUES, 2003, p. 65).

Desse modo, a psicogeografia é um conceito para o qual os problemas desta pesquisa convergem, pois esta visa aborda os processos de subjetivação que o espaço produz. As ideias situacionistas, assim, configuram-se como paradigmáticas às ações artísticas propostas aqui e serão evocadas em inúmeras ocasiões. Entretanto, mesmo apontando tais convergências, os caminhos aqui percorridos buscam criar meios próprios para discutir as fricções entre sujeito e espaço urbano através de experiências
22 "0 urbanismo não uma 'ideologia', no uma 'ideologia', no sentido de Marx. A
arquitetura existe realmente tanto quanto a Coca-Cola: é uma produção envolta de ideologia, mas real. satisfazendo uma necessidade forjada; ao passo que o urbanismo é comparável ao alarido publicitário em torno da Coca-Cola, pura ideologia especular. 0 capitalismo moderno organizado de modo a reduzir toda a vida social a espetáculo, é incapaz de oferecer um espetáculo que própria alienaccãso. Se sonho de urbanismo é sua obra-prima" (Raoul Vaneigem apud JACQUES, 2003, p. 20) 
artísticas; por isso, o termo deriva é substituído por errâncias, do mesmo modo que daremos preferência a cartografia - ao invés de psicogeografia - para as reflexões e observações sobre as afecções da relação sujeito-espaço. Esta postura é estratégica e visa não eleger de imediato determinada corrente de pensamento, precavendo-se de possíveis interpretações anacrônicas tanto na teoria, quanto nas práticas aqui experimentadas.

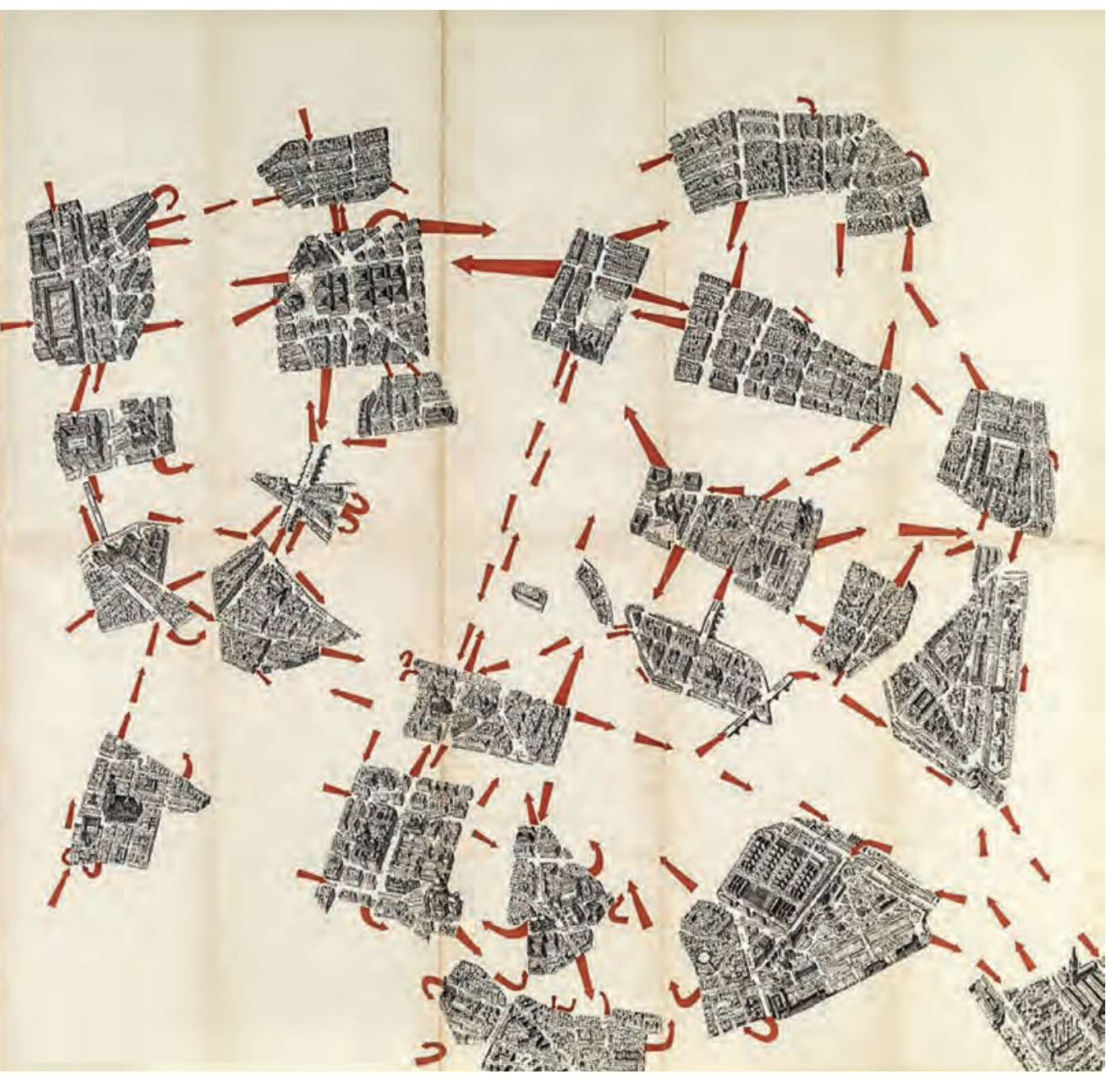

créditos para a experiência e para o saber de experiêncin ressado em distinguir entre experiência e trabalho e lém disso, em criticar qualquer contagem de créditos para a experiência, qualquer conversão da experiência em créditos, em mercadoria, em valor de troca. Minha no tese não somas rainda mais fortente, que a ver com o trabalho, mas, ainda mais fora com as pessoas, com as palavras e com as coisas que chamamo trabalho, é também inimiga mortal da experiência.

sujeito moderno, além de ser um sujeito informado que opina, além de estar permanentemente agitado e em movimento, é um ser que trabalha, quer dizer, que pretende conformar o mundo, tanto o mundo "narural" quanto o mundo "social" e "humano", tanto a "natureza externa" quanto a "natureza interna", sesundo seu saber, seu poder e sua vontade. $O$ trabalho ć esta atividade que deriva desta pretensão. $O$ sujeito moderno é animado por portentosa mescla de otimismo, de progressismo e de agressividade: crê que pode fuer nujo o gre se propồ (e se hoje não pode, algum

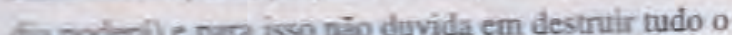

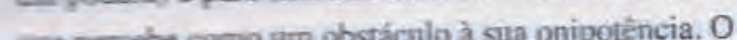

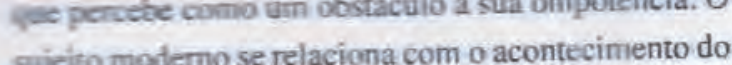
ponto de vista da ação. Tudo é pretexto para sua ativifazer. Sempre está desejando fazer algo, produzir algo regular algo. Independentemente de este desejo estar motivado por uma boa vontade ou uma má vontade, $o$ sujeito moderno ectí arravessado por um afâ de mudar as coisas. E nisso coincidem os engenheiros, os políticos, os industrialistas, os médicos, os arquitetos, os sindicalistas, os jornalistas, os cientistas, os pedagogos e todos aqueles que pöem no fazer coisas a sua xistên $N$ '́n somos sujetos ultra-informados, transhordantes de opiniões e superestimulados, mas também sujeitos cheios de vontade e hiperativos. E por isso, porque sempre estamos querendo o que não é, porque estamos sempre em atividade, porque estamo por nã

podermos parar, nada nos acontece.

A experiência, a possibilidade de que algo no aconteça ou nos toque, requer um gesto de interrupcão, um gesto que é quase impossível nos tempos que corremi requer parar para pensar, parar para olhar, par para escutor, pensar mais devagar, olhar mais per par sentir sentir mais devagar, demorar-se nos detalhes, suspender a opinião, suspender o juízo, suspender a vontade suspender o automatismo da ação, cultivar a atenção e delicadeza, abrir os olhos e os ouvidos, falar sobre -

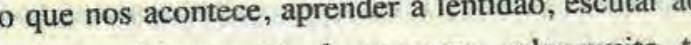
outros, cultivar a arte do encontro, calar muito, ter paciência e dar-se tempo e espaço.

2. Até aqui, a experiência e a destruiçāo da expeVamos agora ao sujeito da experiência. Esse sujeito que não é o sujeito da informação, da opinião, do trabalho, que não é o sujeito do saber, do julgar, do fazer, do poder, do querer. Se escutamos em espanhol, nessa línoua em que a experiência é "o que nos passa", o sujeito da experiência seria algo como um território de passagem, algo como uma superfície sensível. que aquilo que acontece afeta de algum modo, produz Iguns afetos, inscreve algumas marcas, deixa alguns gur . Se escutamos em francês, em estigios, alguns efeitos. Se escris em frances, em que a experiência é "ce que nous arrive", o sujeito da experiência é um ponto de chegada, um lugar a que chegam as coisas, como um lugar que recebe o que hega e que, ao receber, lhe dá lugar. E em português, che "a aquilo que nos acontece, nos sucede", ou happen to us", o sujeito da experiência é sobretudo um espaço onde têm lugar os acontecimentos.

Em qualquer caso, seja como território de passaem, seja como lugar de chegada ou como espaço do acontecer, o sujeito da experiência se define não por sua atividade, mas por sua passividade, por sua receptividade, por sua disponibilidade, por sua abertura Trata-se, porém, de uma passividade anterior à oposição entre ativo e passivo, de uma passividade feita de paixão, de padecimento, de paciência, de atençāo como uma receptividade primeira, como uma disponbilidade fundamental, como uma abertura essencial.

O sujeito da experiência é um sujeito "ex-pos- 


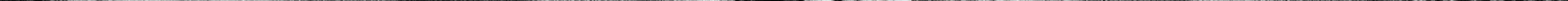


Lua Cnescente, 31 de Outubro है estou ayona. Pretendo fotornatian Sâu pon volta das 10h, 定 Se vecessánio, e assim conse. Vim até o terminal SAcomà. e recém entrei num önibus sem ven ses timenónio, men seu destino, o ónibus estaus pausdo no teraminat e eu apenas enturei e gertei Hoge posso dizer que se

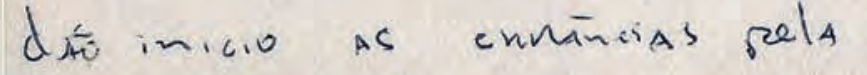
methópole, ate entá já havia nechlizzds alyunas, mas as vejo como torter, Acó̃es de pesyisa pana onde

$$
\begin{aligned}
& \text { quenterrente vecollen alguns } \\
& \text { frogmentos de consurno que } \\
& \text { encortuan pon aí. } \\
& \text { Hoje taubén é o primerno } \\
& \text { dia que sato con o GPS, } \\
& \text { vamar ven o que viná... } \\
& \text { Vin panar no Ipimanga, } \\
& \text { puase heliópolis, divisa com } \\
& \text { Sao caetrano. } \\
& \text { Intenessa use este ine } \\
& \text { phimeino trajeto, primeino } \\
& \text { ponque sem quener/pon } \\
& \text { distuacaso, acaber descendo no }
\end{aligned}
$$

C Meus passos tondor buscuam pon susacés, paisagent, vida, encontrei apstia unbaus Sen crniniats. Pesejan, chizu expectativa uã é cento, de $f$ cento nas recliamo funstado. Só perio ge alojo ertá enuado quardo a penifaria ertis trancada en casa. vilki com 15 fotor e un saw cle,o de funguentor. As wisas caminham. \& nada é cento.
22 de Derembno, Paóx. à Itaquens. SP Fiz um recesso was errizicias pam experiencializan no quant escuno com of objedor qu Andei encontorundo. foi bom este hirto que me fer ven vanias co.sas, entue elas gue preciso peyar un uolume mion de objetor, ua KuA pois or quimicos do labonatóáa certas me daudo un btile Ainds, $\bar{A}$ o muitos resultador improvávas, quando ev acho 1e erti ludo sobve contuole, Alculado, algo s4i encuado, Aparecem mondtas, $A$ emulaso
Errante

Diante de cidades estriadas por ruas e avenidas, de deslocamentos realizados majoritariamente por veículos automotores e de espaços urbanos que não incentivam práticas pedestres, evocar como tática a errância para o deslocamento no âmbito urbano é caminhar no contrafluxo. Assim, produzir e pensar por este viés possibilita uma reflexão crítica sobre a experiência urbana nas cidades atuais.

Com 0 intuito de observar de perto as fricções entre cidade e sujeito por meio do corpo-vibrátil ${ }^{23}$, foram propostas uma série de errâncias que deram origem aos trabalhos Fragmentos e Oju Vitruviano, e seus desdobramentos (ErcíliaSP e Diário), na ocasião da residência artística realizada em 2015 na Oficina Cultural Oswald de Andrade, na cidade de São Paulo. A partir desse conjunto de trabalhos, iniciou-se uma fase da pesquisa voltada para a discussão de como percursos urbanos ordinários incutem discursos.

No processo de produção de Fragmentos, foram estabelecidas previamente algumas "regras" processuais para o trabalho, sendo a primeira delas a busca pelo encontro de formas que promovessem desorientações geográficas em uma cidade até então familiar: para isso, foi estipulado o seguinte método: dirigir-se até um terminal metropolitano de transporte público e adentrar de modo aleatório em algum ônibus estacionado e esperar por sua partida, não sabendo o destino nem o itinerário. Uma vez dentro do ônibus, uma leitura era realizada, como forma de distração, com o intuito
23 Conceito introduzido por Suely Rolnik em Cartografia sentimental (2011), obra da qual destaco as seguintes passagens: "Entre a vibratibilidade do corpo e sua capacidade de percepção há uma relação paradoxal. É a tensão desse

paradoxo que mobiliza e impulsiona a potência de criação, na medida em que nos coloca em crise e nos impõe a necessidade de criarmos formas de expressão para as sensações intransmissíveis por meio das representações que dispomos" (p. 13). "Corpo sensível aos efeitos dos encontros dos corpos e suas reações: simulaçãa em matérias expressão" (p. 31). atração e repulsa, afetos, 
de esperar um momento para o desembarque sem que a atenção estivesse tomada pelo percurso.

De forma aleatória também, o desembarque era realizado e, a partir de então, uma errância pedestre no espaço urbano era encetada. Ao caminhar, outras "regras" do trabalho eram colocadas em prática, como: percorrer o espaço de maneira atenta, observando as sensações provocadas por ele no corpo, até encontrar algum objeto indevidamente descartado no caminho. Após cada encontro, uma fotografia era realizada do local em que o objeto foi encontrado e recolhido, e assim a experiência errática prosseguia pelas ruas, repetindo a dinâmica. Ao final de cada errância, anotações de campo também eram produzidas em um diário, cujo intuito era cartografar as impressões do espaço.

A segunda etapa do trabalho aconteceu no espaço do laboratório fotográfico, onde a coleção de objetos coletados nas ruas era preparada para receber imagens fotográficas, por meio de um processo experimental de fotografia analógica.

Ao transferir as imagens fotográficas para os objetos, invertiase a relação entre objeto e paisagem, pois já não era mais objeto que habitava a paisagem, e sim a paisagem que passava a habitar o objeto em sua superfície, através da fotografia impressa, trazendo à tona - além das questões da linguagem fotográfica - indícios de como a sociedade contemporânea lida com seus descartes, apontando também hábitos de consumo e descasos relacionados à produção de lixo.

Em paralelo à produção de Fragmentos, também se produziu 0 trabalho Oju Vitruviano, cuja poética possui outras singularidades (apesar de fazer uso das mesmas táticas errantes e de utilizar a linguagem fotográfica como meio): trata-se de um autorretrato

.
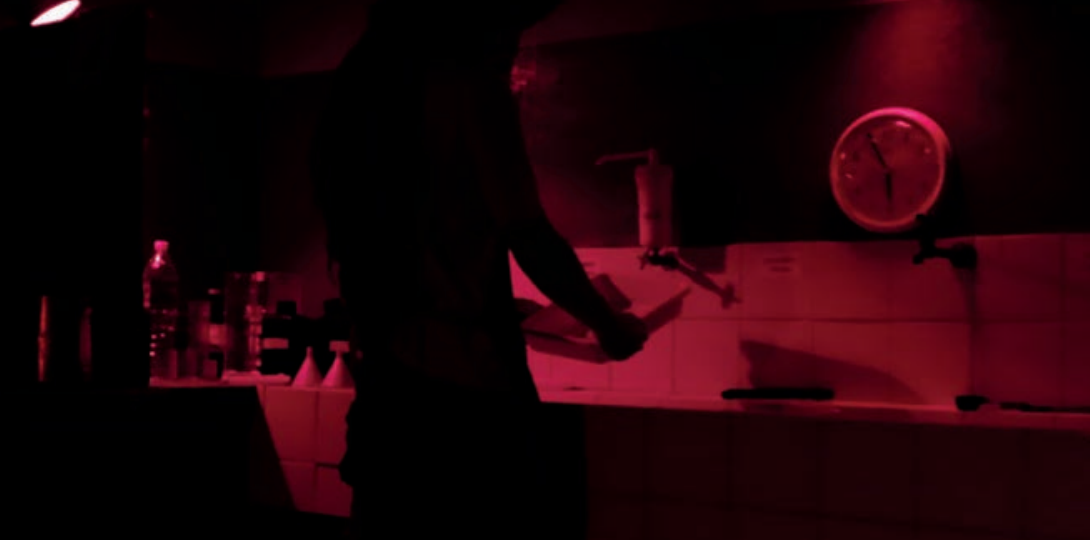
produzido em três etapas, sendo a primeira composta por uma colagem digital de dois autorretratos (em fotografia) em posições que remetem ao desenho Homem Vitruviano, de Leonardo Da Vinci. Um estudo Renascentista das proporções e escalas humanas em relação à arquitetura, e que tem como fundamento para sua produção a obra De Architectura, do arquiteto romano Marcos Vitrúvio, datado do século I.

A partir da montagem do autorretrato de Oju Vitruviano, a imagem foi impressa em papel de celulose no tamanho $2 \times 2$ metros, que, posteriormente foi fragmentada em 25 partes de 40x40 centímetros. Em seguida, cada "pedaço" foi colado em muros nas cidades de São Paulo, São Bernardo do Campo e Santo André, por meio da técnica lambe-lambe. Após um mês, cada fragmento da imagem original foi novamente fotografado com as inscrições que as intempéries e intervenções humanas realizaram sobre o papel. De volta ao ateliê, estes fragmentos são reunidos e formam o mosaico Oju Vitruviano, com 25 impressões sobre canvas, montadas em chassis de madeira.

Se com seu desenho Leonardo Da Vinci pretendia trazer à tona a filosofia humanista frente à teologia cristã hegemônica na Europa da época, o que se pretendeu ao lançar os fragmentos de Oju Vitruviano nas ruas atuais foi problematizar as lógicas nas quais a sociedade contemporânea está alicerçada e 0 jogo de interesses presentes nos modos dos sujeitos se relacionarem com o espaço público.

Outra questão, ainda não mencionada, do processo de produção dos trabalhos Fragmentos e Oju Vitruviano é que todos os percursos das errâncias realizadas foram registrados em dados de GPS, fornecendo um panorama preciso das localizações das ações urbanas empreendidas, embora in locu a desorientação
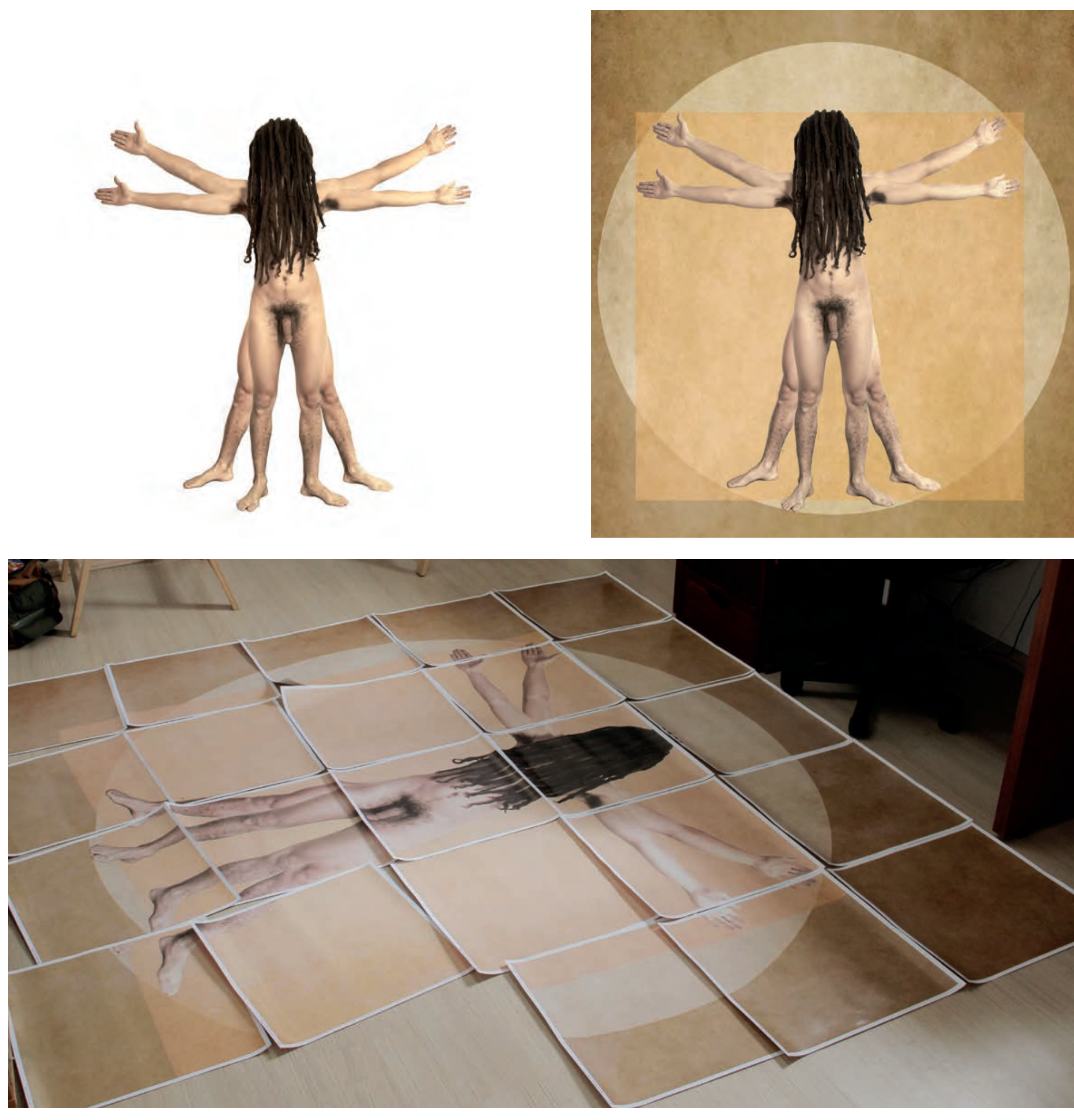


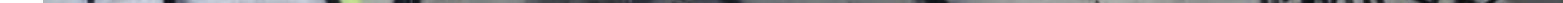




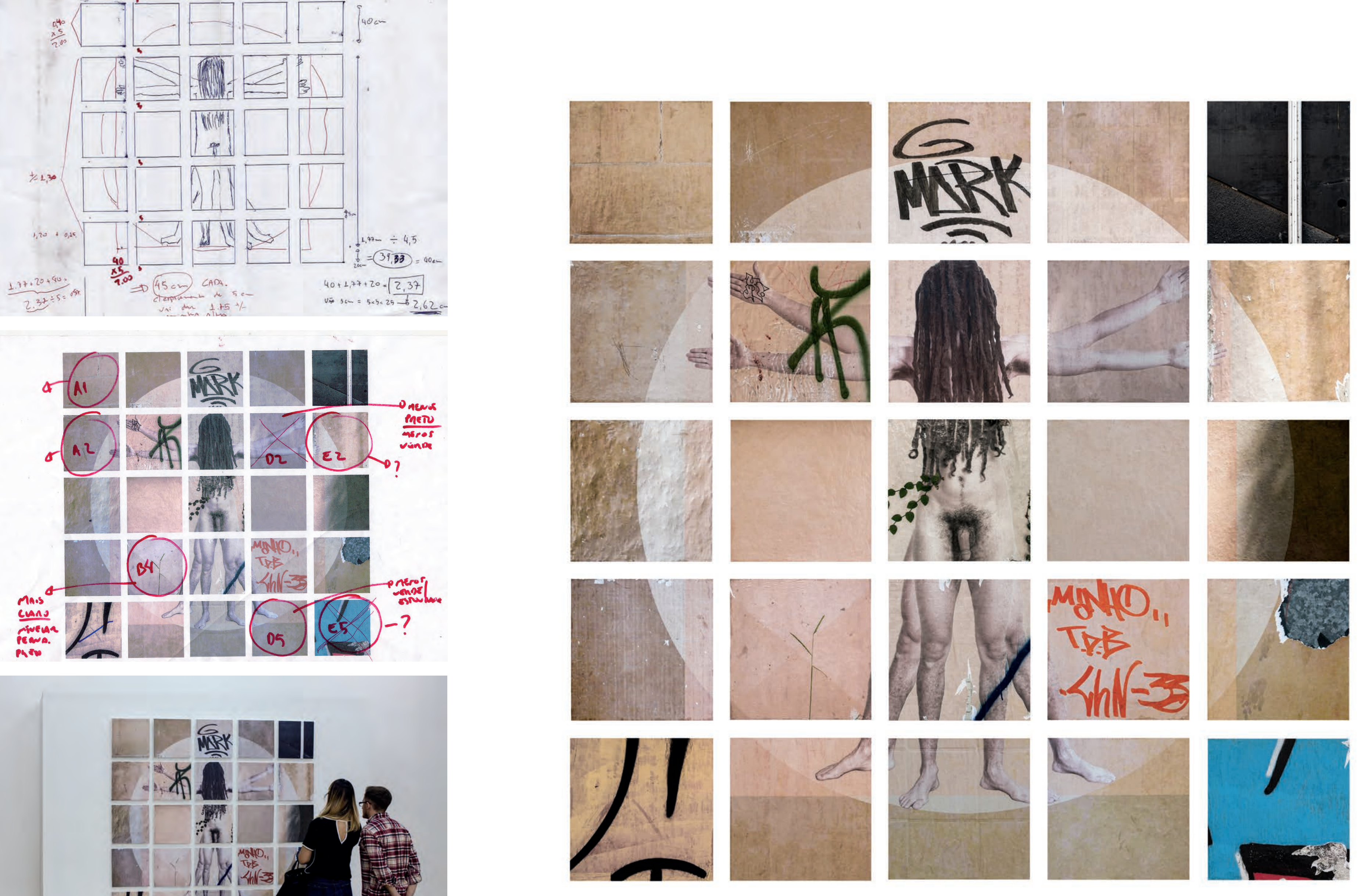


espacial compusesse uma parte fundamental das operações. Ao fim do período de três meses de errâncias, esses dados serviram de base para a construção do trabalho ErcíliaSP: um objeto composto de madeira, adesivo vinil, pregos e linhas que remete aos trajetos percorridos nas errâncias, e cujo nome faz alusão a uma das "cidades invisíveis" de Italo Calvino, em que a narrativa do conto coincide com o gesto de olhar para "trás" a partir das trilhas de GPS.

Em Ercília, para estabelecer as ligações que orientam a vida na cidade, os habitantes estendem fios entre as arestas das casas, brancos ou pretos ou cinza ou pretos e brancos, de acordo com as relações de parentesco, troca, autoridade, representação. Quando os fios são tantos que não se pode mais atravessar, os habitantes vão embora: as casas são desmontadas; restam apenas os fios e os sustentáculos dos fios.

De costado de um morro, acampados com os móveis de casas, os prófugos de Ercília olham para 0 enredo de fios estendidos e os postes que se elevam na planície. Aquela continua a ser a cidade de Ercília, e eles não são nada.

Reconstroem Ercília em outro lugar. Tecem com os fios uma figura semelhante, mas gostariam que fosse mais complicada e ao mesmo tempo mais regular que a outra. Depois a abandonam e transferemse juntamente com as casas para ainda mais longe. Deste modo, viajando no território de Ercília, depara-se com as ruínas de cidades abandonadas, sem as muralhas que não duram, sem os ossos dos mortos que rolam com o vento: teias de aranha de relações intricadas à procura de uma nova forma. (CALVINO, 2003, p. 74)

Assim como os "habitantes" da Ercília de Italo Calvino, que abandonam uma cidade para construir outra a partir de novas relações, em 2017, uma nova fase da pesquisa inicia-se, tendo dessa vez uma experiência errática coletiva, por meio da proposta

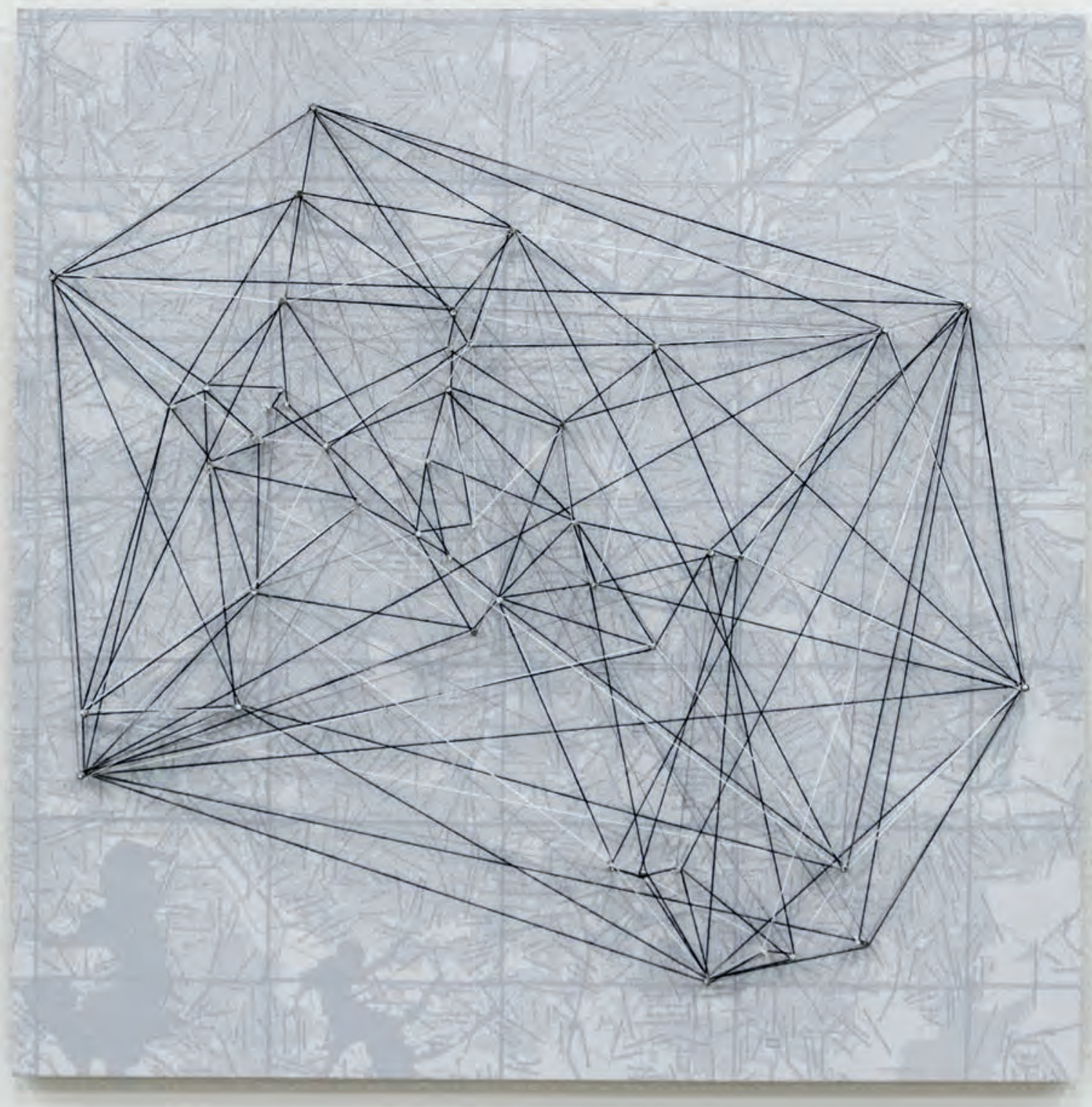


24 "Em resumo, nãa queremos dizer que a TAZ um fim em si mesmo. substituindo outras formas de organização táticas e objetivos. Nós recomendamos porque ela pode fornecer qualidade do enlevamento associado ao levante sem necessariamente levar à violência e a martirio. A TAZ e un espécie de rebelião

stado diretamente, uma

Estado diretamente, uma operação de guentiha que de tempo, de imaginação de tempo, de imaginaçáa

em outro lugar e outro

moutro lugar e outro Estado possa esmagá-la "

(BEY, 2001 , p. 17)

250 ano de 20

foi marcado pela

consolidação do

impeachment da

presidente Dilm

Rousseff. Nas rede sociais, algun

advogavam pelo retorno

ditadura Milita

No Rio de Janeiro,

aconteceu a ocupaçăo

militar no morro da

Rocinha, em que

soldados usavam capuzes

de caveiras pelas ruas,

cenas "surreais" que

podiam sem vistas nas

capas de jornais. (Por

exemplo, em: <https://

www.cartacapital.com

br/sociedade/militare

usam-mascaras-de-
caveira-durante-
a

operacao-na-rocinha> . do trabalho Nuncat, um cortejo realizado nas ruas da cidade de São Paulo e que integrou a programação do Festival La Plataformance.

As operações poéticas de Nunca+ iniciam-se com a criação, uma semana antes da ação, de um "coletivo autônomo temporário", inspirado nas ideias das "zonas autônomas temporárias" do livro TAZ, de Hakim Bey²4. Para formar esse coletivo, foram distribuídos panfletos virtuais cujo conteúdo relacionava: cunho político da criação de um grupo para propor experiências estéticas no espaço público à conjuntura da política brasileira ${ }^{25}$.

Na ação Nuncat, os próprios integrantes não sabiam quais cursos seriam realizados na cidade, sendo a proposta da errância um aspecto central no trabalho. Assim, no momento da ação, um dos membros do grupo foi aleatoriamente eleito para guiar cortejo pelas ruas. Este membro seguia na frente, carregando uma bandeira preta em mastro, sendo seguido por um grupo de quatro integrantes que carregavam, por sua vez, uma escultura de madeira, e uma banda de músicos formada por instrumentos de sopro e percussão, que expandia o corpo do trabalho para outros espaços da cidade através da propagação do som.

Outros signos e elementos do trabalho também auxiliavam para a criação de estranhamentos e microdesestabilizações por onde o cortejo passava: a utilização do rosto coberto por máscaras pretas, os capacetes verdes utilizados pelos integrantes do coletivo, a bandeira preta em haste e a escultura de madeira transportada do começo ao fim da ação, cuja forma lembrava um caixão. Esses aspectos ressaltam que nas operações poéticas de Nuncat, além do deslocamento performático do coletivo no espaço urbano, a alegoria também era parte das operações poéticas, sobretudo nos objetos utilizados e que tinham seus valores simbólicos alterados pelo contexto.

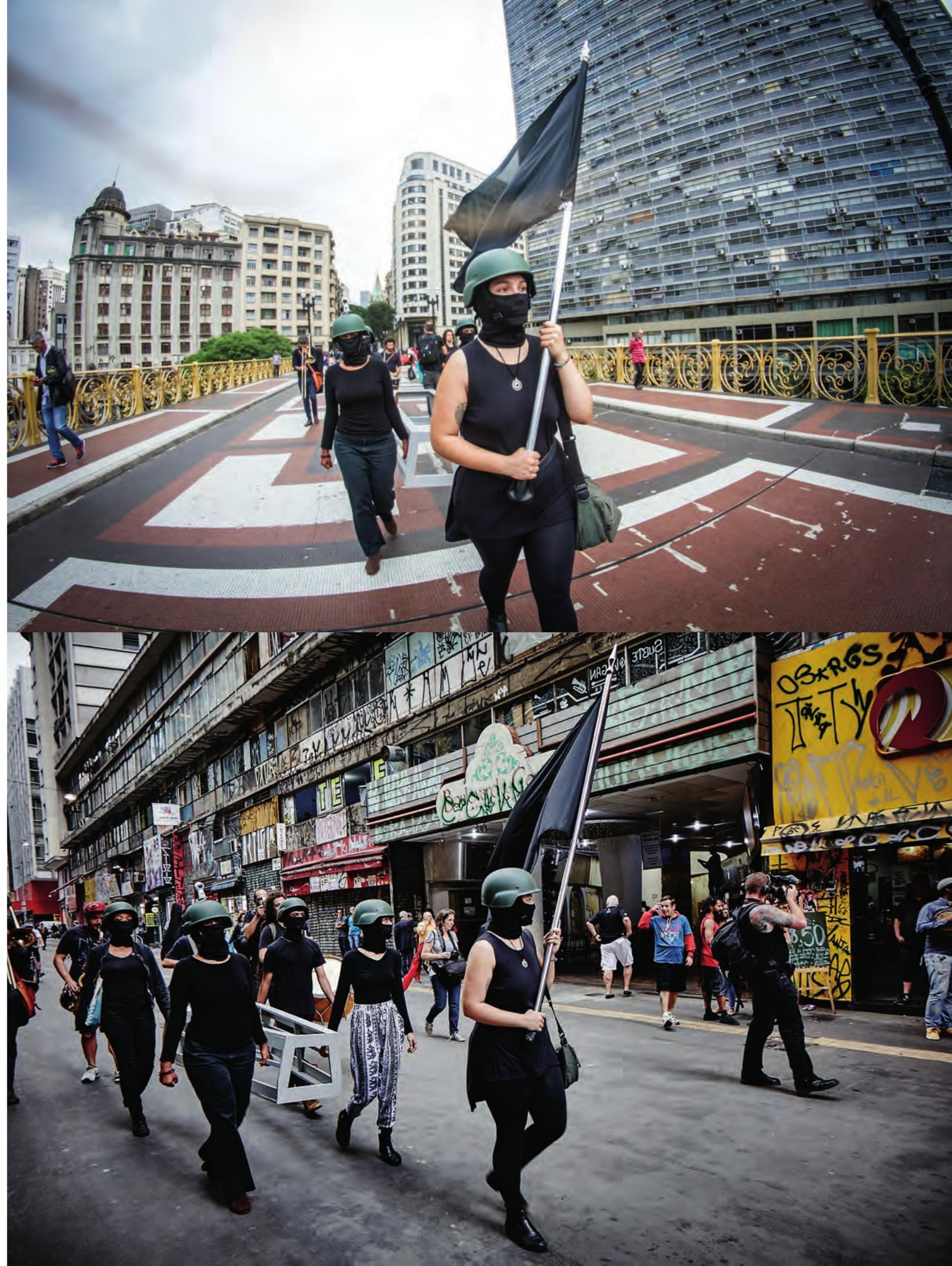




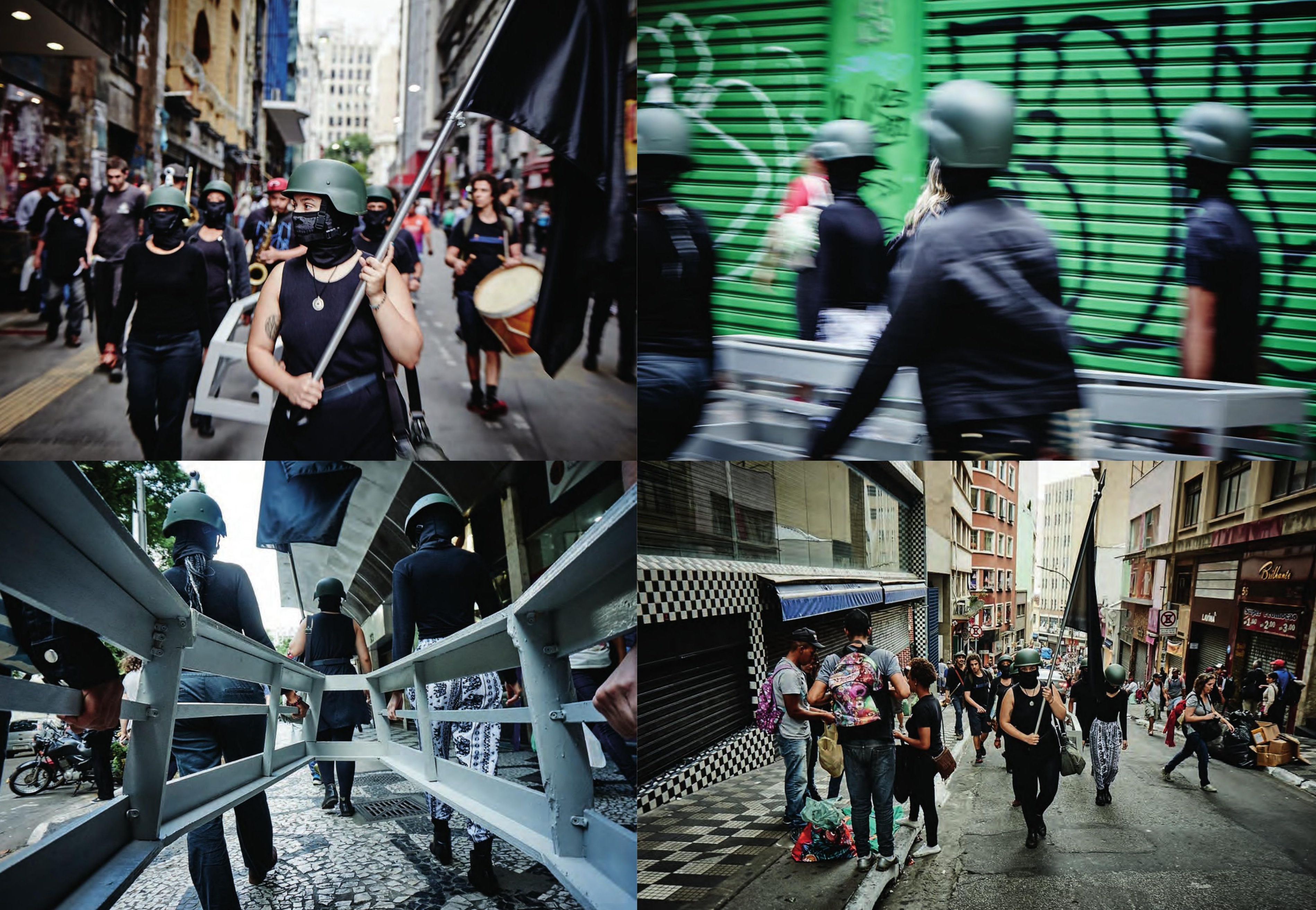




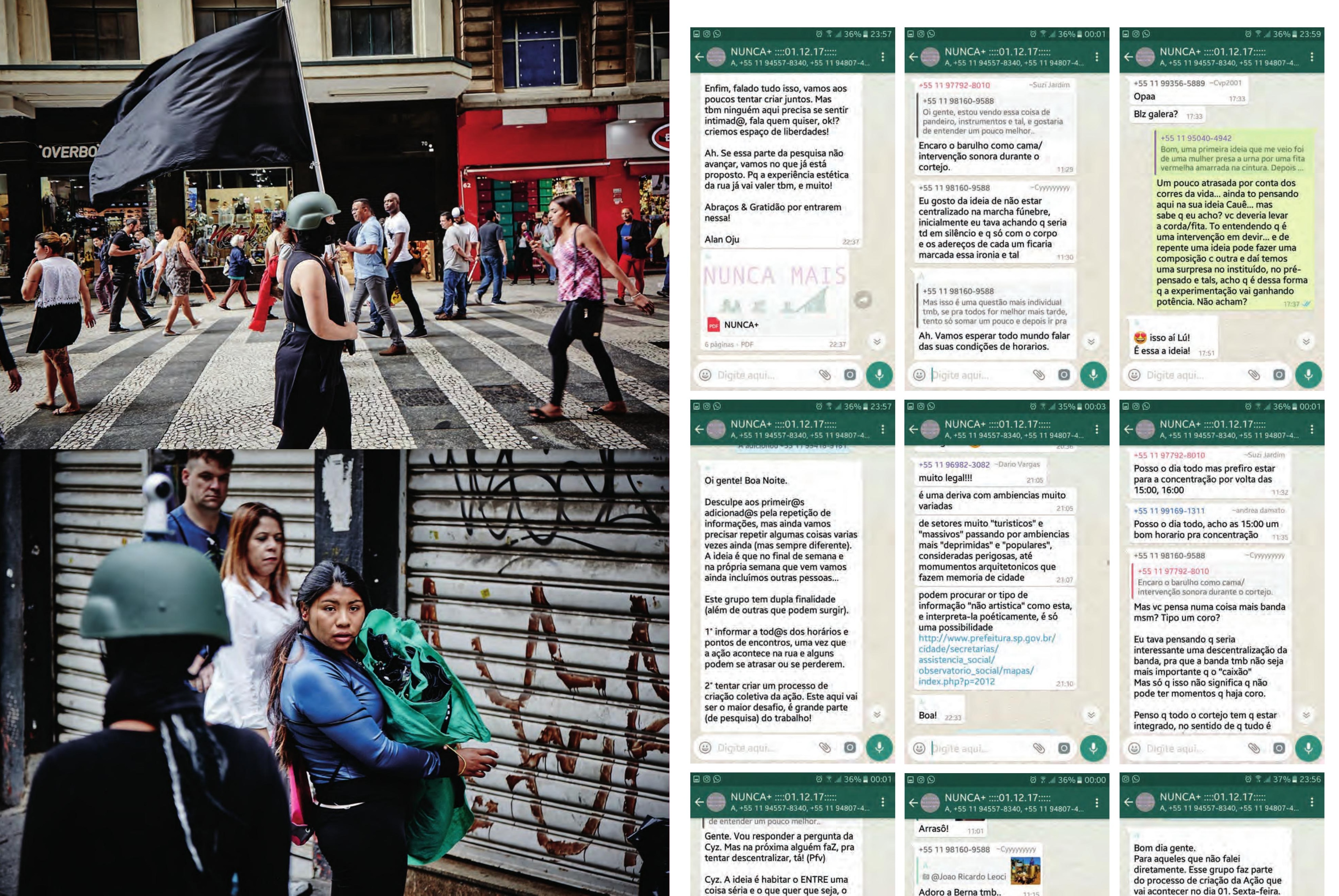




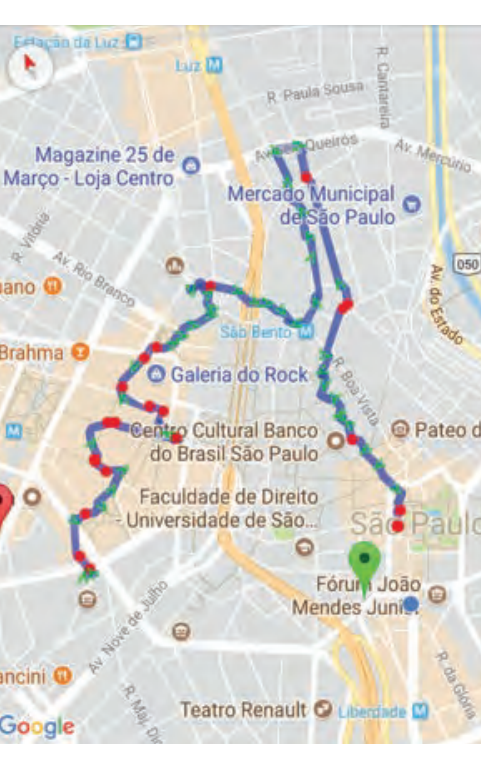

26 “Na metrópole contemporânea

escultura perde toda

transcendência, sü

chiga grandeza. A

capacidade de nos

fazer levantar os olhos

para o céu. Não fã

mais ninguém para

Desaparece o lugar que

estatua tinha na cidade,

constitutivo de se

caráter de obra de arte

(PEIXOTO, 1996, p. 131)
Da ação Nunca+ também se desdobrou a série fotográfica Monumento-Presente, composta de seis fotografias de paisagens urbanas em que, no centro de seus espaços, localizava-se a escultura de madeira a que o coletivo, na ação, seguia em cortejo. As fotografias dessa série foram realizadas dias após a ação. Para produzi-las, percorreram-se novamente os mesmos trajetos realizados pelo coletivo anteriormente.

Monumento-Presente faz alusão aos inúmeros monumentos espalhadas pelo espaço urbano que encarnam a "alma da cidade", segundo Nelson Brissac, ao trazerem à lembrança dos cidadãos fatos históricos, mitos e fábulas que habitam o imaginário da cidade, função que nas metrópoles contemporâneas está cada vez mais esvaziada de sentido ${ }^{26}$. Por ser constituída de forma vazada, sem delimitações precisas entre dentro e fora, a escultura de madeira, como o próprio nome da série sugere, remete ao presente do espaço e aos acontecimentos do cotidiano. Se os monumentos oficiais enaltecem fatos heroicos, MonumentoPresente expressa as invisibilidades e o efêmero.

A ação Nuncat, além de dar origem à série fotográfica Monumento-Presente, também inaugura novas possibilidades de operações poéticas na pesquisa, em especial a capacidade de produzir e pensar sobre o caminhar como prática estética em coletivo. E, ao lado dos trabalhos anteriores - Fragmentos, Oju Vitruviano, Diário e ErcíliaSP -, integram o desejo de reflexão crítica acerca de relações possíveis entre sujeito e espaço público a partir das errâncias urbanas.
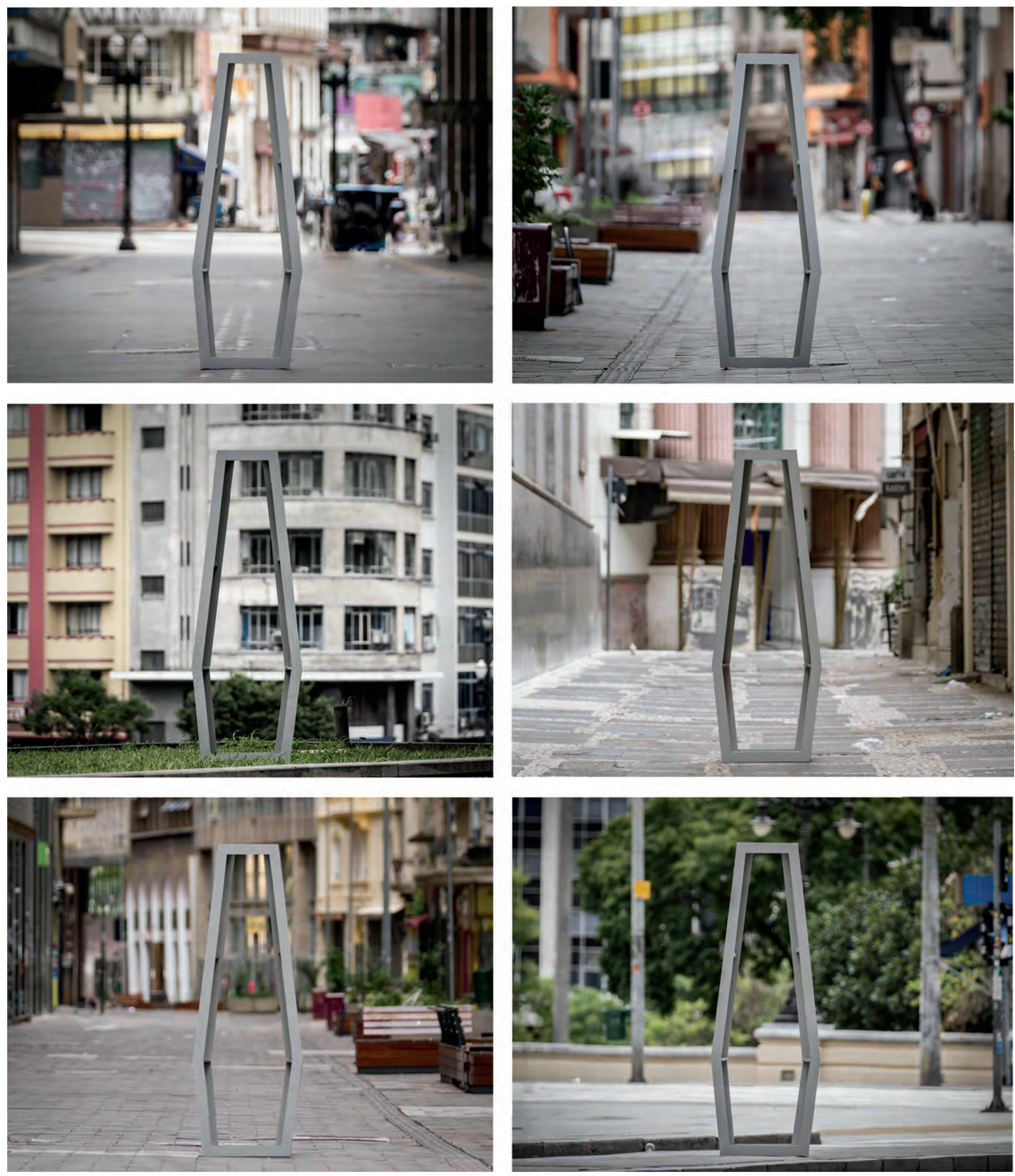


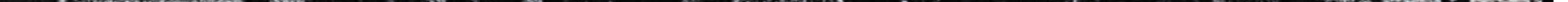

Curso, percurso, discursos

Nas experiências realizadas no espaço urbano que geraram os trabalhos anteriormente apresentados, destacaram-se ainda as imagens construídas a partir de dados em GPS, desenhos realizados no espaço pelos cursos espontâneos das errâncias empreendidas. Michel De Certeau diz que o ato de caminhar encontra sua definição na enunciação pedestre, que assim como a língua se torna real na ação da fala, o caminhar é a realização do espaço que se faz a cada passo em curso, potencializando discursos através dos percursos:

0 ato de caminhar está para o sistema urbano como a enunciação (o speech act) está para a língua ou para os enunciados proferidos. Vendo as coisas no nível mais elementar, ele tem com efeito uma tríplice função "enunciativa": é um processo de apropriação do sistema topográfico pelo pedestre (assim como o locutor se apropria e assume a língua); é uma realização espacial do lugar (assim como 0 ato de palavra é uma realização sonora da língua); enfim implica relações entre posições diferenciadas, ou seja, "contratos" pragmáticos sob a forma de movimentos (assim como a enunciacão verbal é "alocução", "coloca o outro em face" do locutor e põe em jogo contrato entre colocutores). 0 ato de caminhar parece, portanto, encontrar uma primeira definição como espaço de enunciação. (...) "O usuário da cidade extrai fragmentos do enunciado para atualizálos em segredo". (CERTEAU, 1994, p.164-165)

Conforme 0 pensamento de Certeau, a cada passo o caminhante escreve 0 "texto da cidade". Com o intuito de "ouvir" o que os percursos têm a dizer, comparemos a imagem dos trajetos de 
Fragmentos, representados no estudo digital para a produção do trabalho ErcíliaSP, com um estudo do sociólogo francês Paul-Henry Combart de Lauwe (1913-1998) intitulado "Trajets pendant un an

d'une jeune fille du XVle arrondissement"27, produzido em 1957,

para assim ler o que os dois tem a dizer a partir de suas diferenças.

0 trabalho de Paul-Henry Combart de Lauwe trata-se de um acompanhamento dos trajetos de uma jovem na cidade de Paris 0 que se vê na imagem ao final do estudo, é uma rotina de estrutura triangular correspondente aos deslocamentos da jovem entre sua casa, a escola de ciências políticas na qual estudava e a casa do professor de piano. Assim, podemos observar uma rotina que pouco explora o espaço integral da cidade, concentrando a vida em uma área restrita. Rotina que poderíamos ler também como uma vivência retraída do espaço urbano, geradora de menores possibilidades de encontros e que possivelmente pode reverberar nas escolhas da vida. Uma rotina "mecânica", à qual elevado número de pessoas está sujeito nas cidades, e que opera na manutenção da lógica cíclica de produção e consumo do capitalismo. Já o estudo para Ercília SP mostra uma ocupação mais espalhada do mapa da região metropolitana de São Paulo, efetivada pelos acasos do método errante.

Quando comparamos tais imagens, devemos levar em consideração também aquilo que se esconde nas entrelinhas, ou seja, as múltiplas possibilidades de encontros e afetos presentes nas contiguidades: nas sucessões de pontos em movimento que dão forma as linhas, nos espaços entre. Portanto conforme maiores as distâncias dos trajetos e a forma como são percorridos, maiores são as possibilidades de acontecimentos desterritorializantes na cartografia existencial e nos mapas desenhados em escala 1:1 no cotidiano.
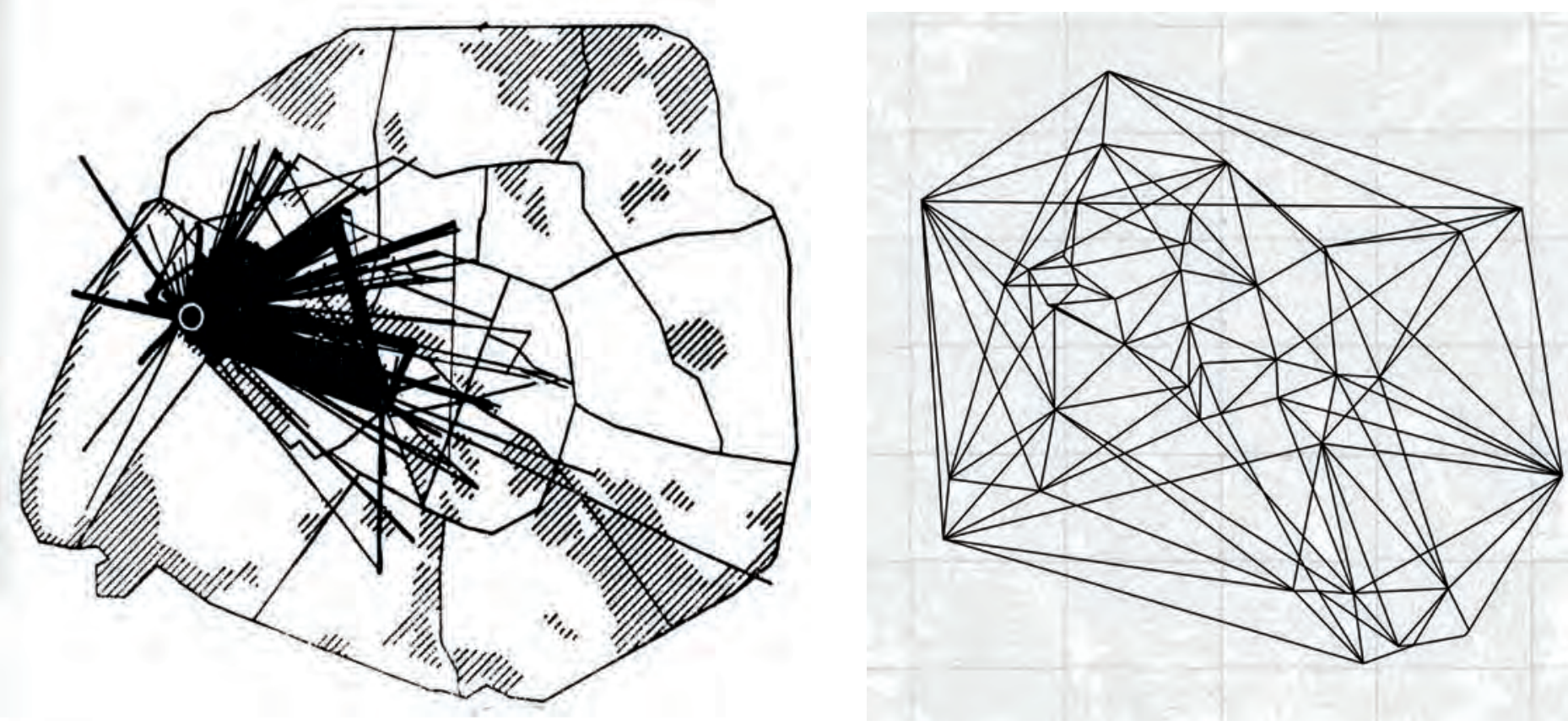

0 "texto" das errâncias empreendidas carrega a palavra desfuncionalização em negrito, terminologia quase inexistente em outros discursos, em que é tomada como "perda de tempo" ou "riscos desnecessários". A partir da noção de cidade como um organismo em que os diversos órgãos trabalham em nome da organização produtividade do corpo-cidade, as errâncias se contrapõem a esta conformação ao criar, através experiência da desfuncionalização dos percursos, um Corpo sem Órgãos ${ }^{28}$, que visa promover encontros de devires, cruzamentos de linhas, fluxos e intensidades - contatos que modificam mutuamente suas estruturas e movimentos. Ou seja, enquanto o discurso do organismo mantém a ordem e não coloca em risco o corpo-cidade, as errâncias justamente buscam 0 oposto, em nome de uma vivência do espaço menos funcional e mais lúdica, propondo assim - como os situacionistas já o fizeram - sobrepor simbolicamente o homo faber pelo homo ludens através de "situações lúdicas construídas" 29

Na esteira da crítica que os situacionistas fizeram à "sociedade do espetáculo" e dos objetivos funcionalistas da arquitetura do urbanismo modernista, as errâncias também pretendem problematizar o processo de espetacularização da vida nas cidades através da corporeidade de seus praticantes no espaço público.
28 "Um CsO [Corpo sem Orgãos] é feito de tal maneira que ele só pode ser ocupado, povoado por intensidades. Somente as intensidades passam e circulam. Mas o cso não é uma cena, um lugar, nem mesmo um suporte onde aconteceria um fantasma, nada a interpretar. 0 CsO faz passar intensidades, ele as produz e as distribui num spatium ele mesmo intensivo, não extensão. Ele não é o espaço e nem está no espaço, é matér que ocupará o espaço em tal ou qual grau grau que corresponde às intensidades produzidas. 1996, p. 16)

29 "Situações lúdicas construídas": experiência construtivas que levariam seus praticantes a refleti também sobre seus cotidianos, como família trabalho, consumo, organização políitica etc. 
Enquanto a participação cidadã é a cada dia mais influenciada pela lógica da cidade-mercadoria, buscar construir experiências no ambiente urbano é um gesto de microrresistência política.

0 conceito de "sociedade do espetáculo", cunhado pelos situacionistas, refere-se à crítica de que a sociedade passou a viver em função de representações que mediam as relações sociais, substituindo experiências verdadeiras por imagens, simulacros, fenômeno que abrange todas as esferas da sociedade. Atualmente, no âmbito do espaço urbano, esse processo se vê vertiginosamente intensificado com as chamadas "cidades globais", onde o planejamento estratégico uniformiza as cidades de acordo com os imperativos do mercado. Aos poucos, as grandes cidades do mundo vão se tornando cada vez mais parecidas, e estas novas cidades e seus bairros veem seus aspectos culturais serem alterados. Por consequência seus habitantes gradualmente perdem o direito sobre a cidade e o espaço urbano, deixando de vivenciá-los em todas as suas potencialidades. A cidade domesticada acaba assim por domesticar seus moradores, que deixam de viver experiências de alteridade e aos poucos incorporam a lógica do espaço artificializado em suas vidas. Estes novos ambientes estéreis anestesiam as experiências urbanas, configurando parte de uma rede de processos de subjetivação em que a sociedade contemporânea está envolta. A ação de "errar" - de permitir-se aos acontecimentos na urbe, de estar propenso às intercorrências e perder-se no espaço - compõe a tática empregada nesta pesquisa, fundamentada na experiência do corpo-a-corpo no espaço urbano, e nas fricções geradas nessa ação.

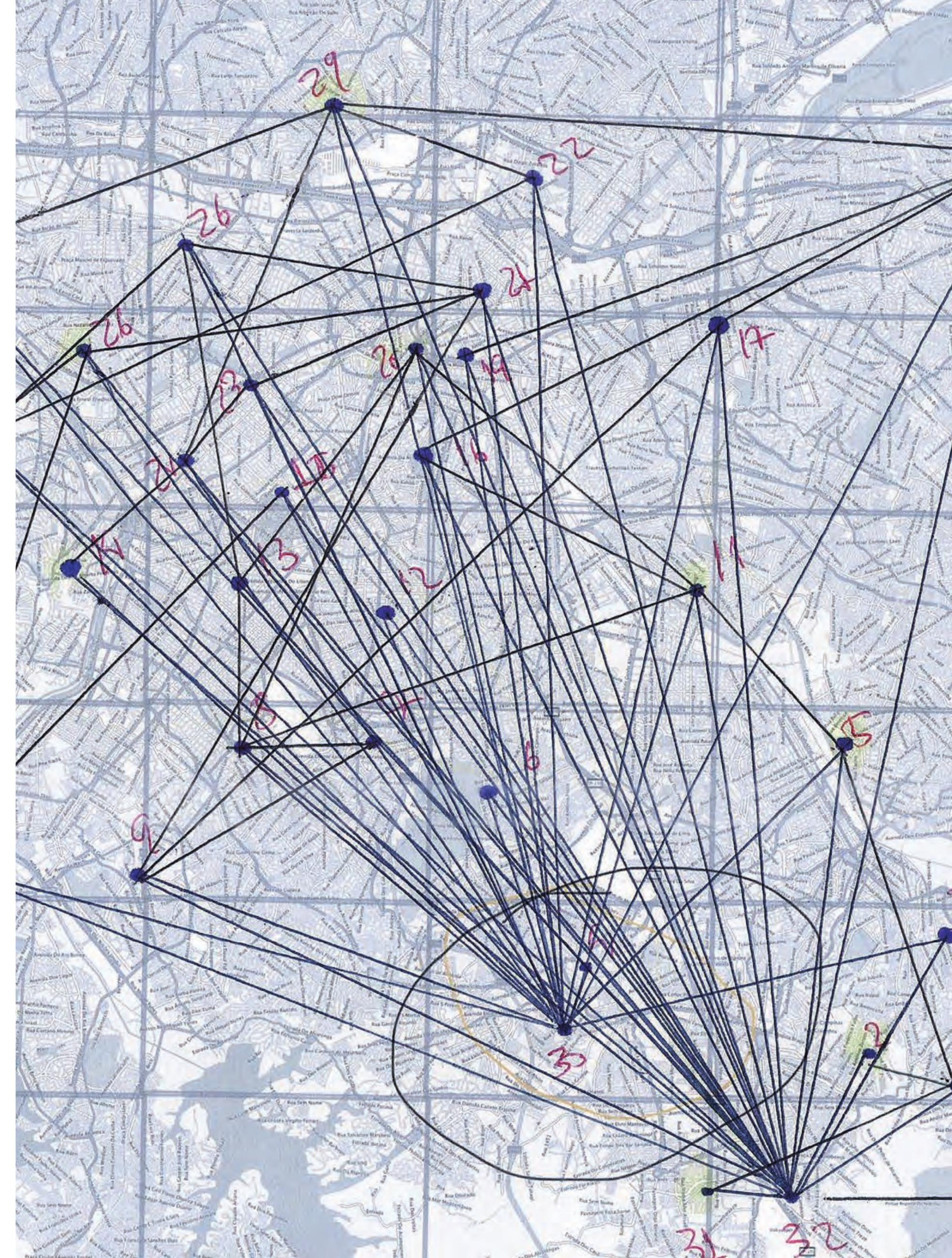




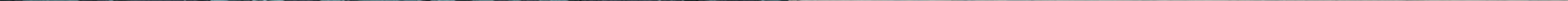




$$
B
$$




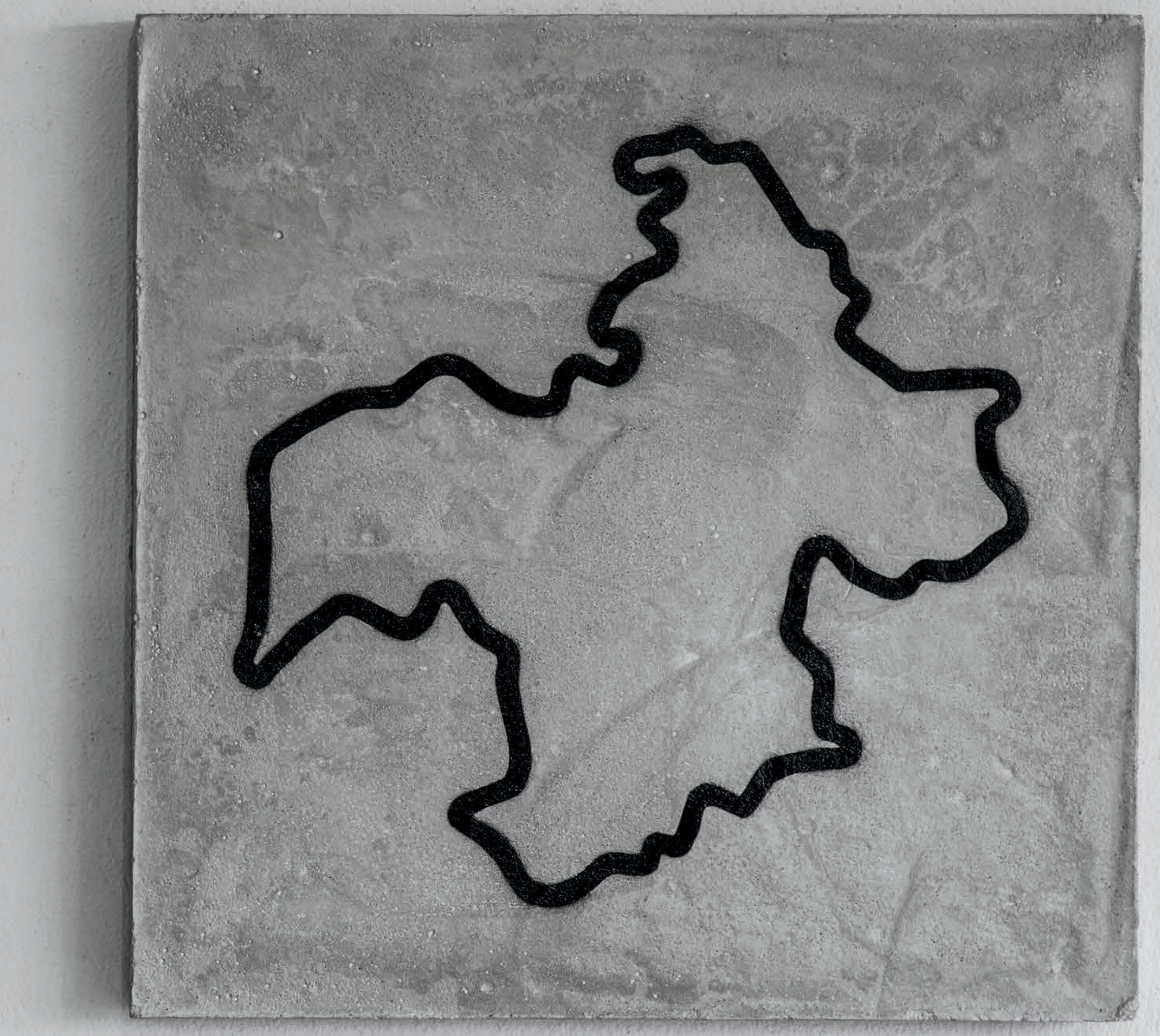




$$
\{\}
$$




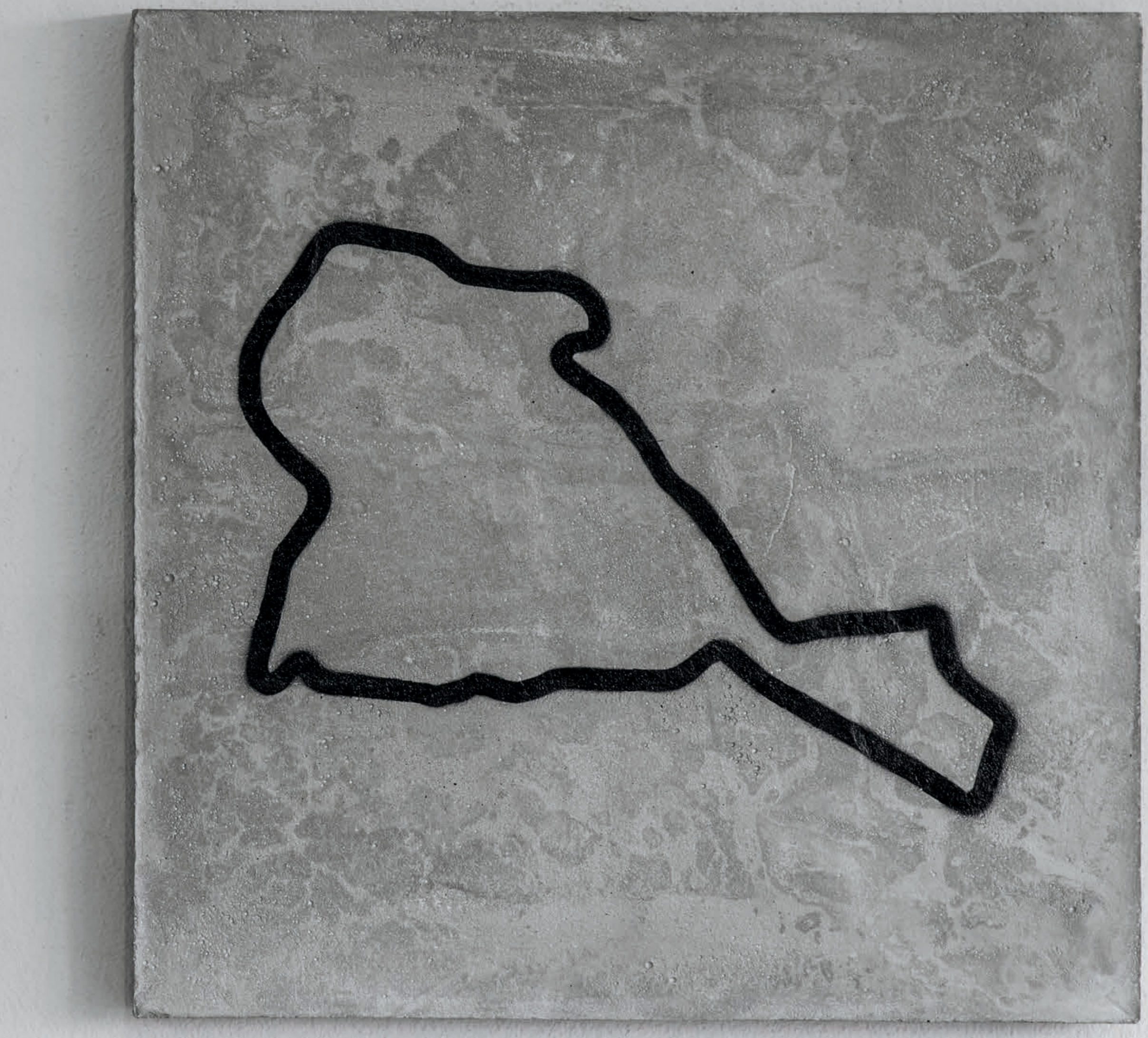




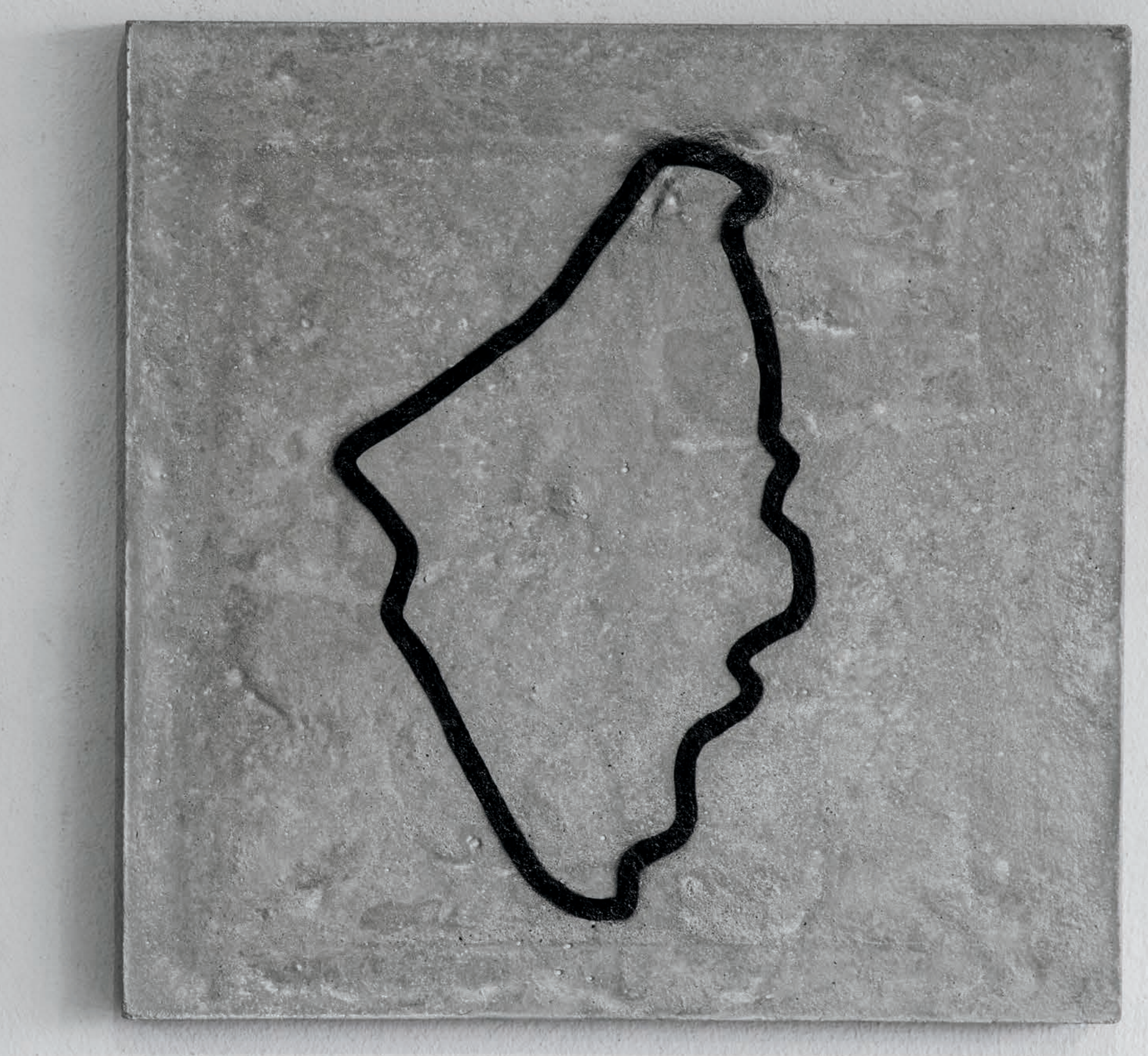




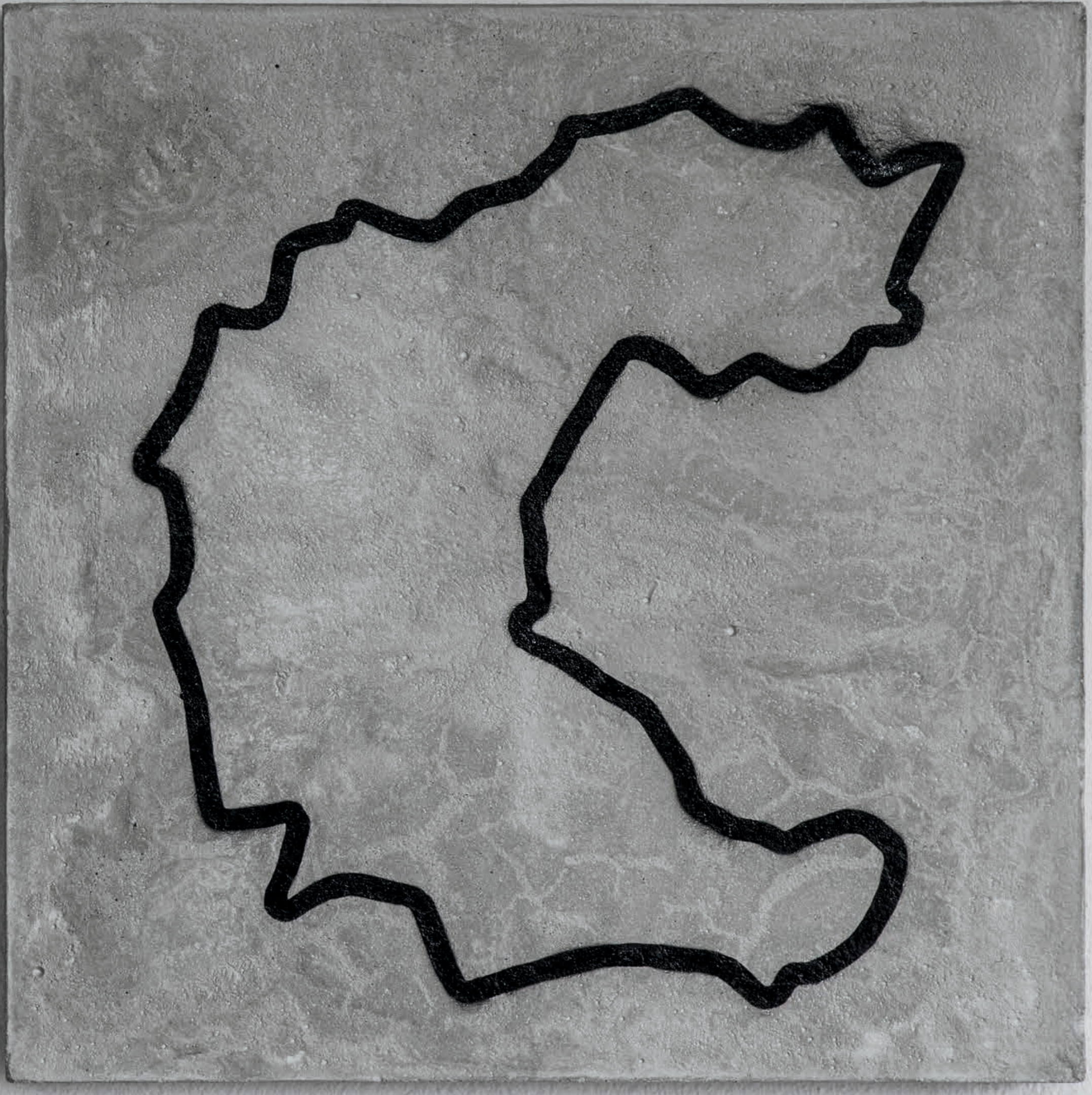




$$
\Omega
$$




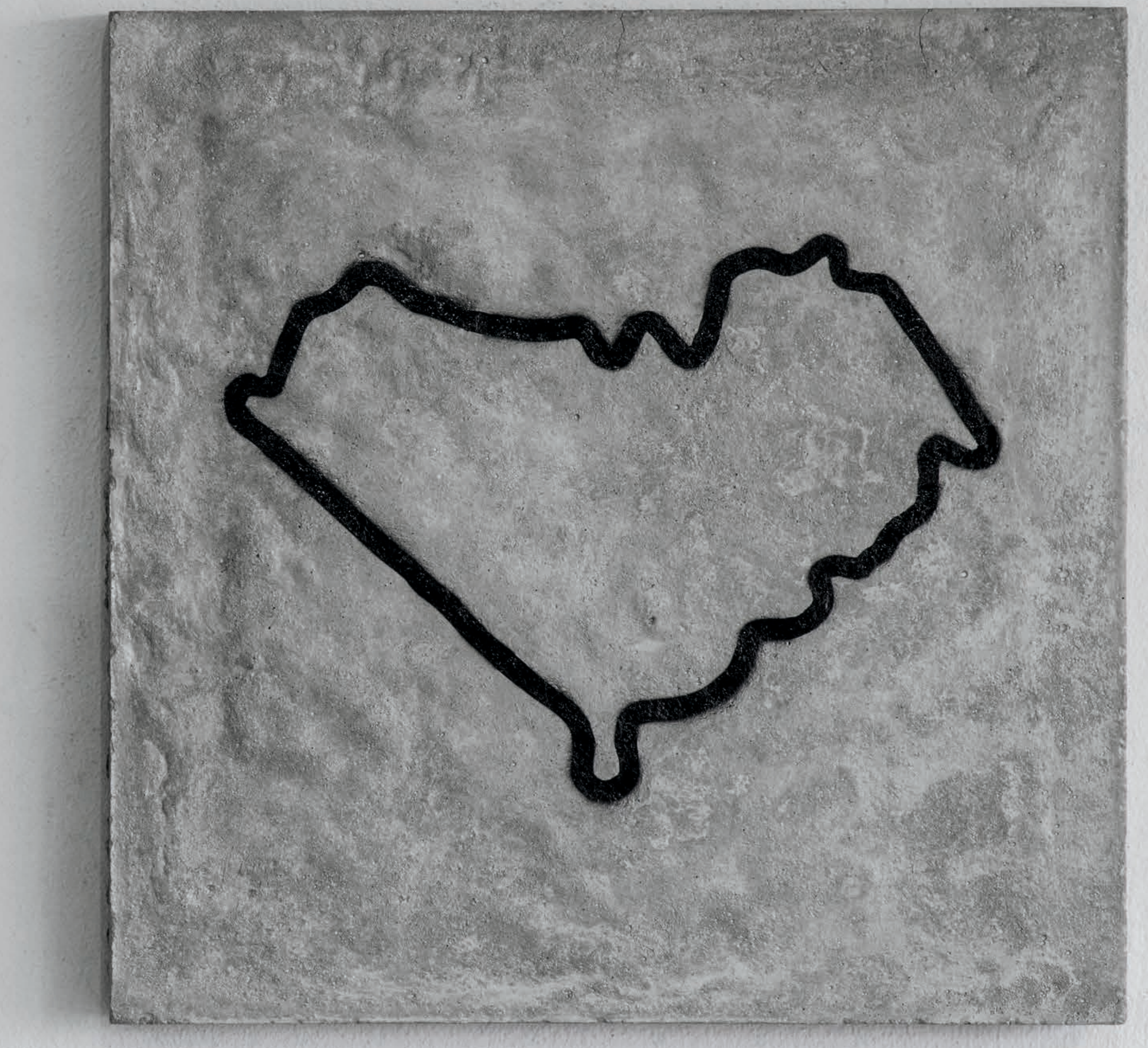




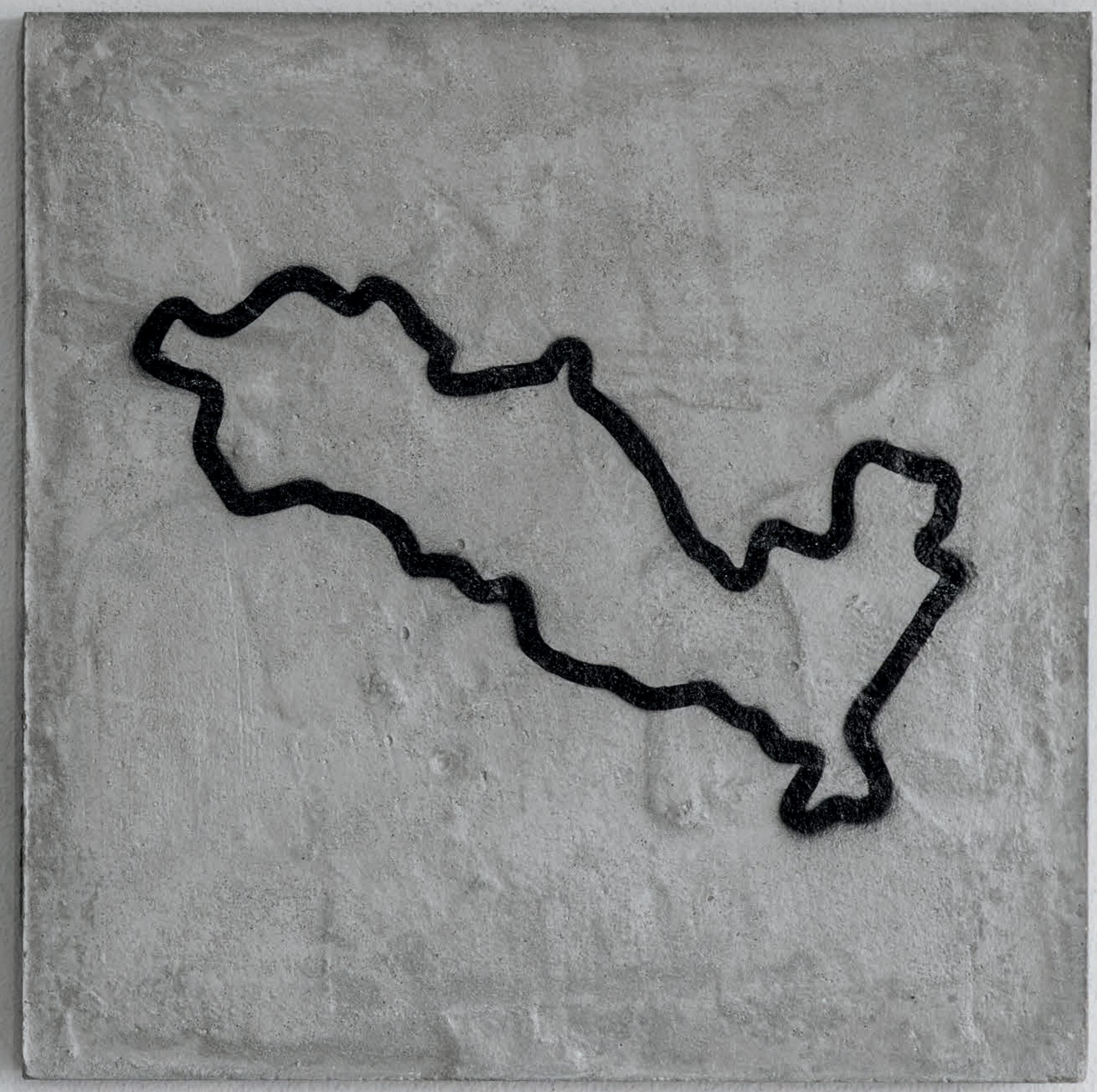




$$
5
$$




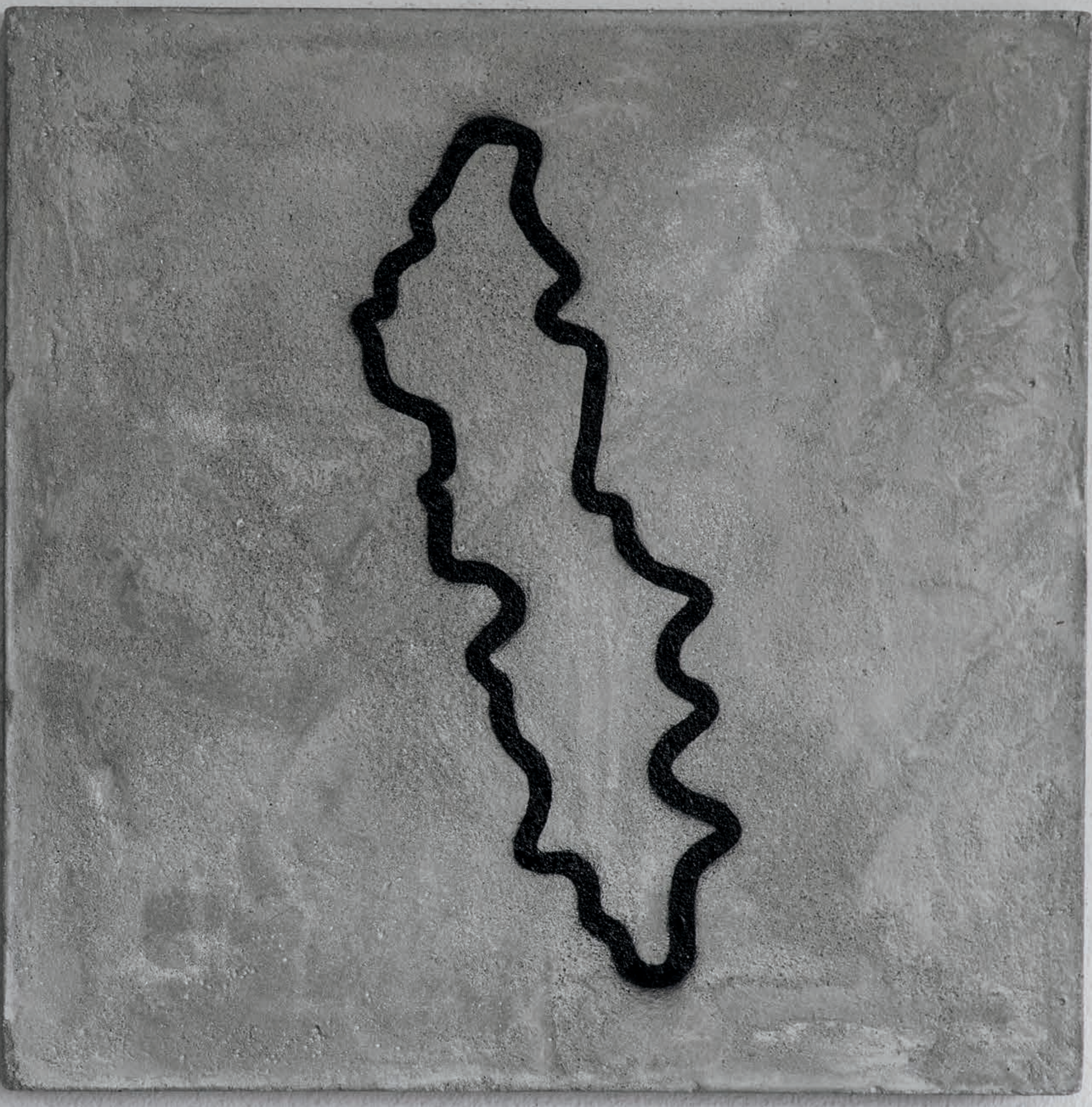




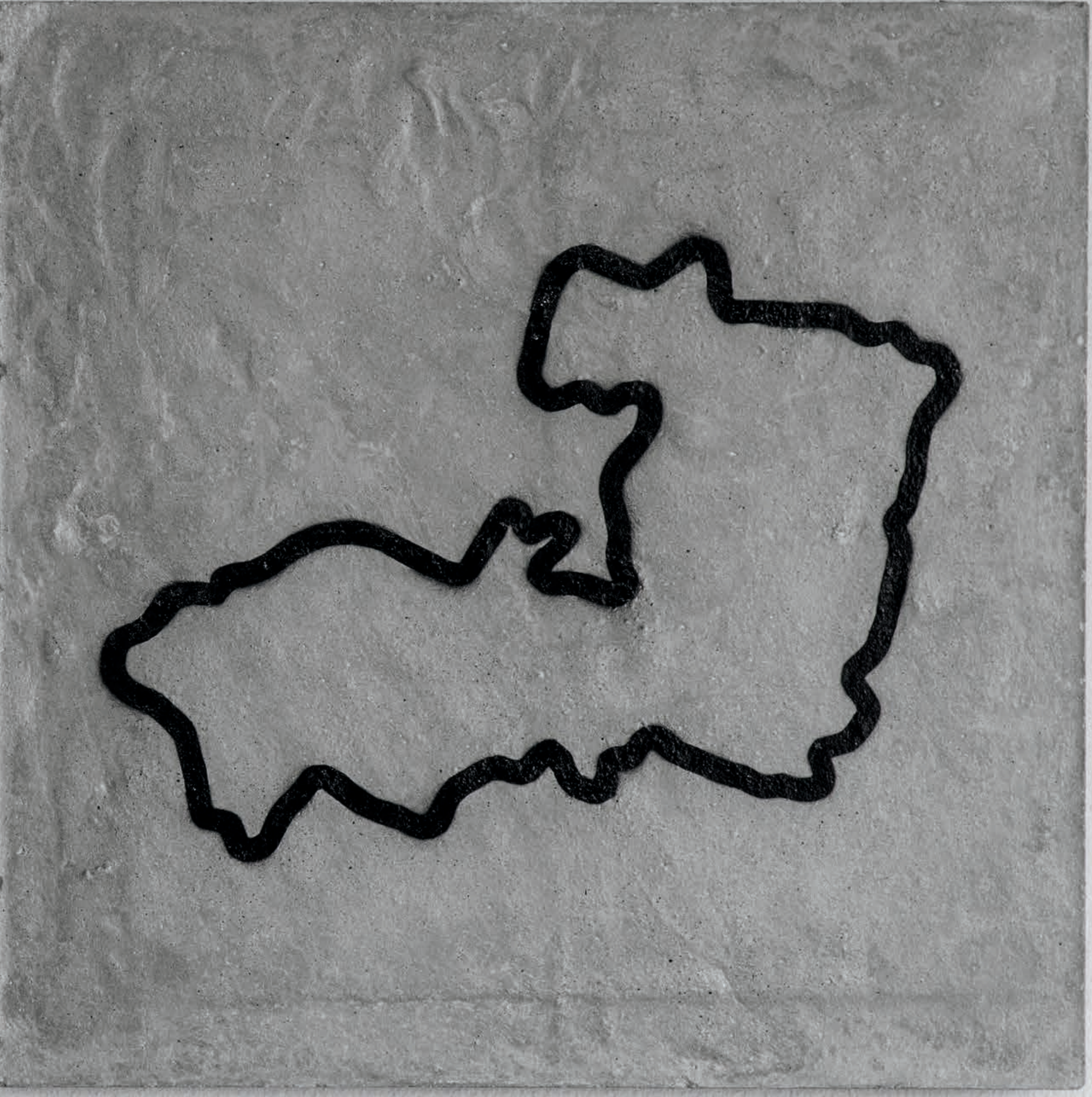




$$
\text { रु? }
$$




$$
\mathrm{M}_{3}
$$




$$
[3
$$




$$
\sigma
$$




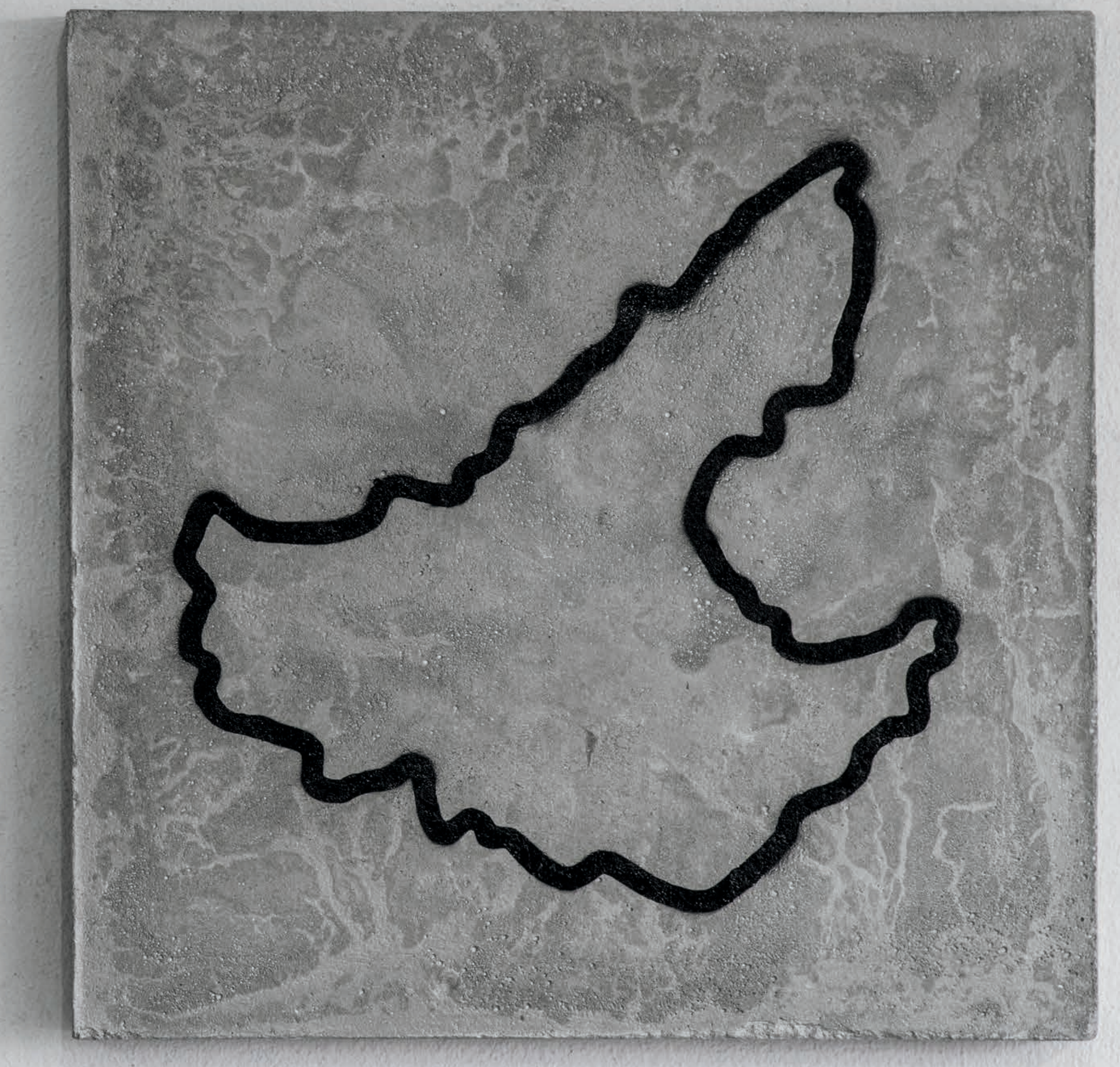




$$
0
$$




$$
\omega
$$




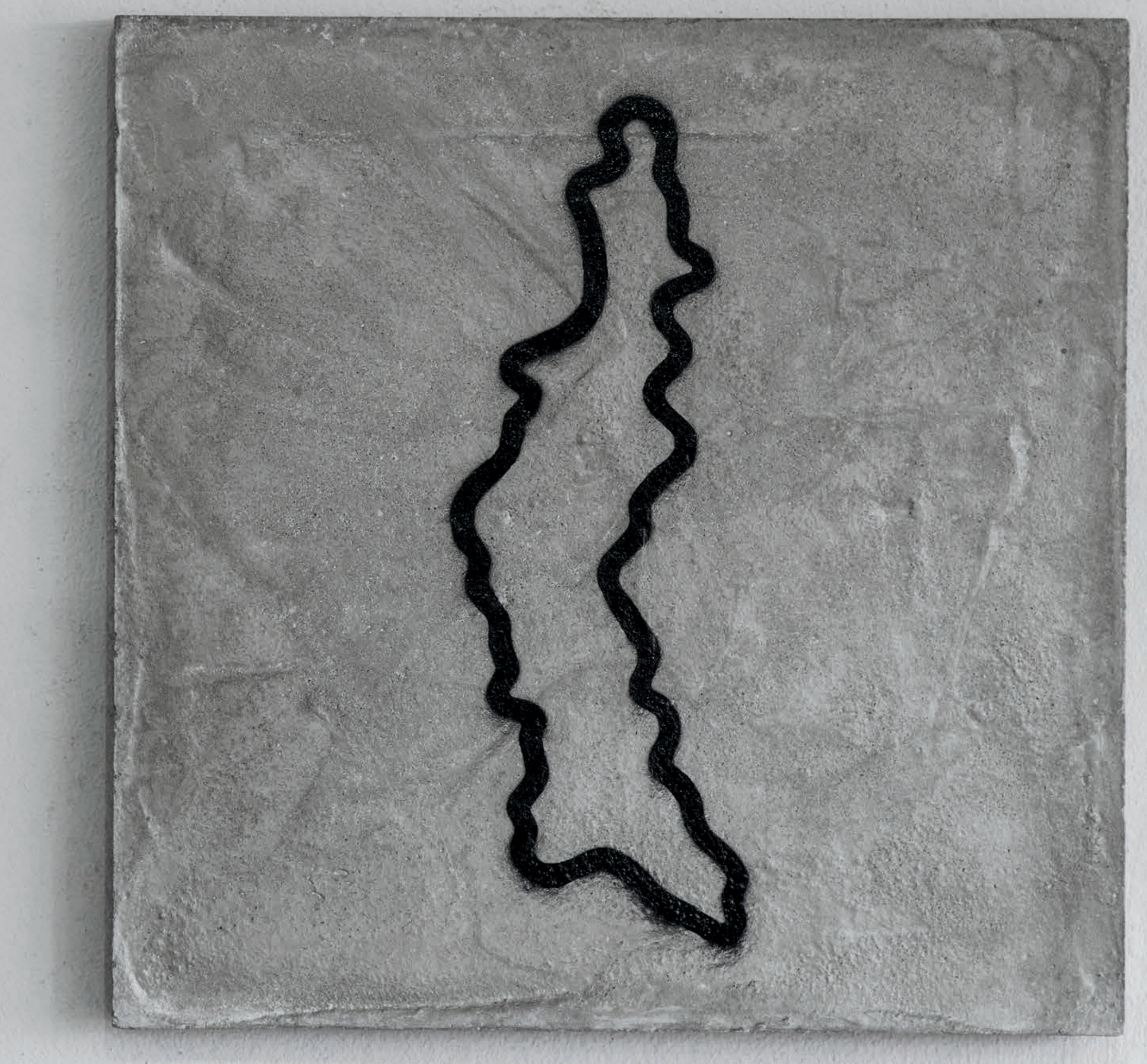




$$
\beta
$$




$$
\Omega
$$




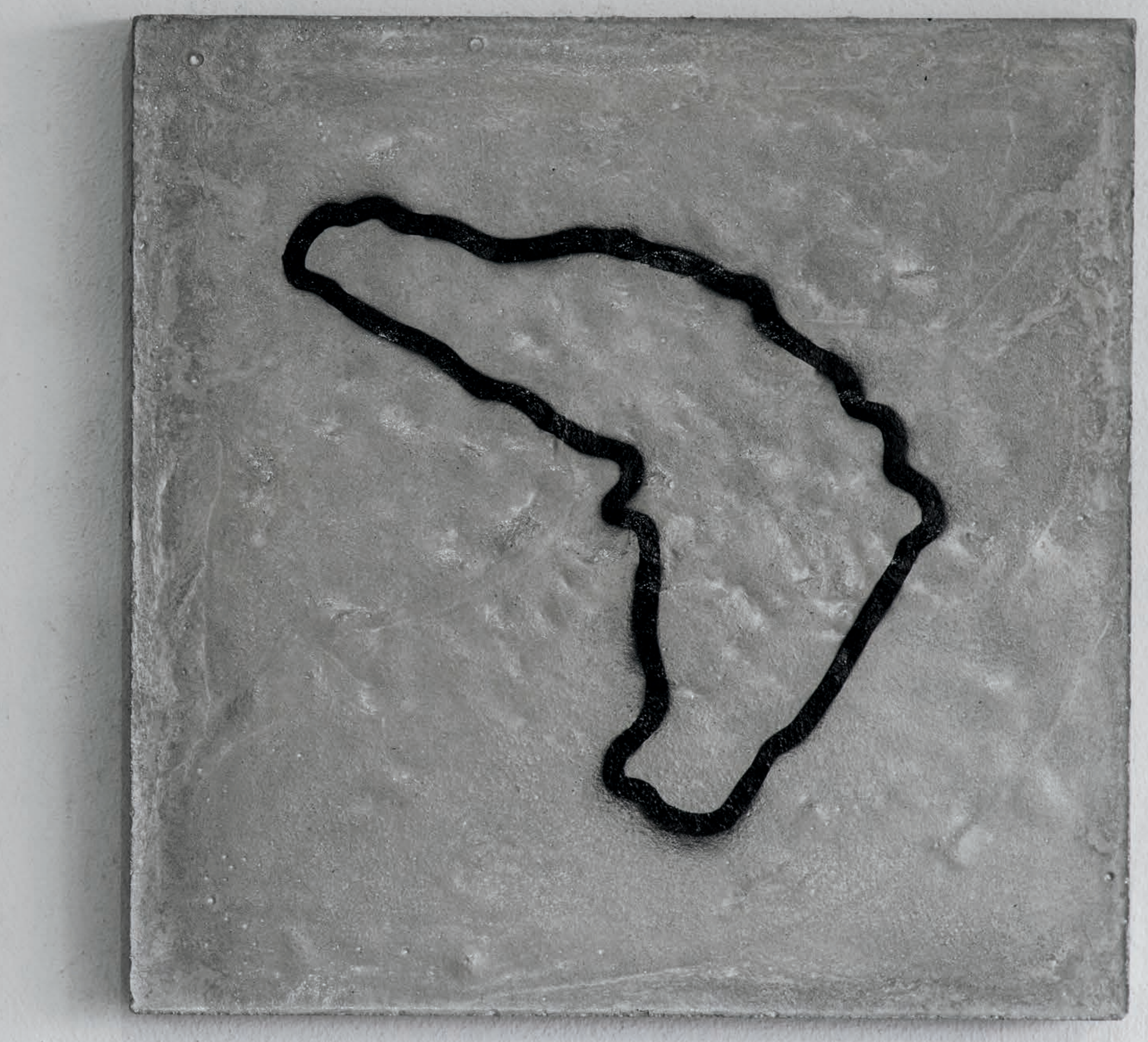




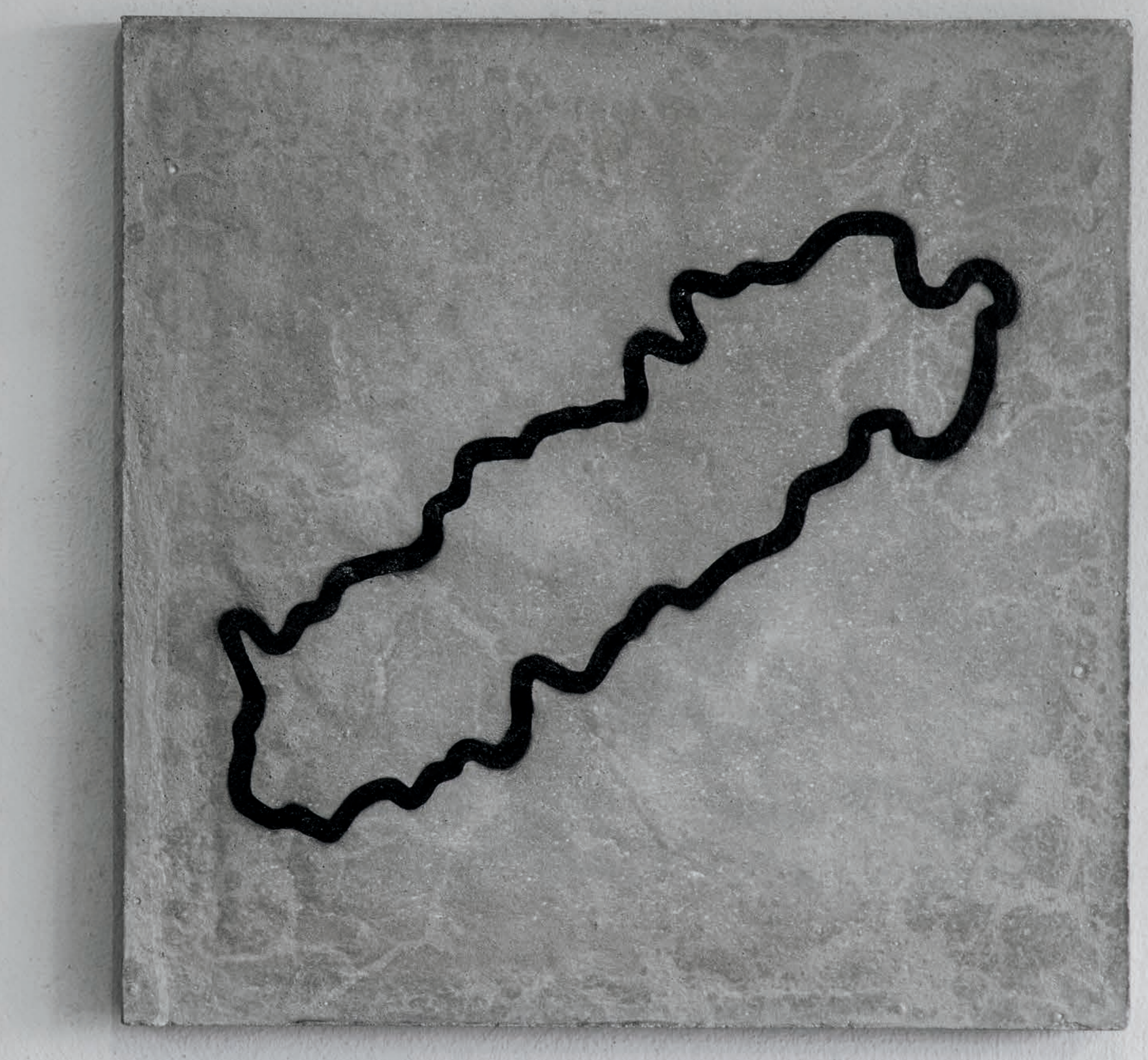



Máquinas de subjetivação

Vimos no capítulo anterior a potência da "desfuncionalização" da experiência urbana por meio dos trajetos ordinários na cidade, e que sair da dinâmica prático-funcional produz efeitos singularizantes. Agora, aprofundemo-nos no campo dessa subjetividade urbana em como esse sujeito produz e é produzido pela paisagem urbana, entendendo "paisagem" aqui como contexto de relações (estéticas, físicas, sociais, políticas, afetivas etc.). Assim, percorreremos os caminhos constitutivos dos sujeitos urbanos, para no segundo momento demonstrar que os mesmos podem se também constituintes de si, não em regimes identitários ${ }^{30}$, mas sim em escolhas e novos modos de existências.

A noção de sujeito não é algo estanque e universal, conforme demonstrou o filósofo Michel Foucault ao analisar o tema de forma transversal em seus trabalhos desde a Grécia Antiga ao século $X X$, destacando que cada sujeito corresponde ao tempo e espaço no qual está inserido. Segundo Foucault, há dois significados para a palavra: "sujeito a alguém pelo controle e dependência, e preso a sua própria identidade por consciência ou autoconhecimento. Ambos sugerem uma forma de pode que subjuga e torna sujeito a." (FOUCAULT apud DREYFUS RABINOW, 1995, p. 235). Os estudos de Foucault demonstram que "subjugações" efetivam-se por meio de tecnologias do "saber" ao longo da história no Ocidente, engendrando padrões de "normalidade", por meio da biologia, que ocupa-se do sujeito vivente; da economia, centrada no sujeito produtivo; e da lingüística, encarregada do sujeito falante. sujeito da noção de identidade, pois atribuições de unidade dos regimes identitários, quando não empregadas em estratégias políticas contestatórias, podem servir para oprimir e ignorando singularidades e movimentos dos sujeitos. 
produtoras de signos, de sintaxe e de subjetividade, por intermédio, especialmente, do controle que exerce sobre a mídia, a publicidade, as sondagens etc. (...) Proponho reagrupar em quatro principais regimes semióticos os instrumentos sobre os quais repousa o $\mathrm{CMl}$ :

a) as semióticas econômicas (instrumentos monetários, financeiros, contábeis, de decisão...

b) as semióticas jurídicas (título de propriedade, lesgislação e regulamentações diversas...);

c) as semióticas técnico-científicas (planos, diagramas, programas, estudos, pesquisas...);

d) as semióticas de subjetivação, das quais algumas coincidem com as que acabam de ser enumeradas, mas conviria acrescentar muitas outras, tais como aquelas relativas à arquitetura, ao urbanismo, aos equipamentos coletivos etc. (GUATTARI, 2012, p. 31)

Nesta fase de pesquisa, nos concentraremos sobre as semióticas de subjetivação, pois são principalmente por meio delas que as artes e as relações entre sujeito e espaço acontecem (no sentido fenomenológico do termo); entretanto, vale ressaltar, conforme aponta Guattari, que todas as semióticas atuam de modo integrado e muitas vezes coincidem.

Os dispositivos das semióticas de subjetivação possuem escalas diversas, e podem variar tanto em jogos de linguagem entre indivíduos quanto nos múltiplos contextos das megalópoles, sendo inúmeros os processos de subjetivação que agem de formas complementares na constituição dos sujeitos, produzindo a subjetividade heterogênea, composta por inúmeros fluxos semióticos. Parte desse processo faz-se por via da subjetividade coletiva, com os mass-media (a publicidade, o cinema, a televisão, etc.), assim como em nacionalismos e arcaísmos religiosos, entre tantos outros componentes da subjetividade social, maquínica e estética que acossam cotidianamente os indivíduos.

Um outro modo dos agenciamentos de enunciação se refere às subjetivações parciais, que aqui, por questões de recorte, estarão resumidas ao espaço urbano: relações entre o corpo do sujeito e o corpo da cidade. Este último, constitui-se em uma grande máquina produtora de sentidos, interpelando os sujeitos de modo funcional, afetivo, estilístico, histórico, entre outros.

Estamos, assim, diante de um complexo regime semiótico, que opera em dois modos: significante (onde conseguimos distinguir o emissor discursivo) e assignificante (em formas espaciais, ritmos, ritornelos), ambas capazes de influenciar os sujeitos, produzindo sentidos, identificações e maneiras de perceber o mundo capazes de efetuar o que Maurizio Lazzarato nomeia de servidão maquínica, atuante no "espírito da vida", controlando os seres humanos "por dentro", no nível pré-pessoal (nível pré-cognitivo e pré-verbal), e "por fora", no nível suprapessoal (LAZZARATO, 2014, p. 38) intervindo em comportamentos básicos: perceptivo sensitivo, afetivo, cognitivo, linguístico, entre outros. 
Contornando limites

Em meio ao fogo cruzado de signos que constitui o sujeito contemporâneo, a arte também opera em modos variados nos processos de subjetivação, podendo efetuar assujeitamentos ou ressingularizações. Ao longo dos capítulos anteriores, vimos como relações estéticas na cidade são capazes de dar visibilidade a máquinas abstratas de subjetivações parciais, como os muros e os trajetos funcionais ordinários. Abordemos agora a questão da sociabilidade urbana, com o intuito de problematizar o sujeito urbano em devir, tendo os condomínios residenciais como problemática central a partir da poética do trabalho Enclaves Fortificados.

Enclaves Fortificados introduz outra fase à pesquisa, na qual novas materialidades e linguagens são operadas. Assim como a maioria dos trabalhos já apresentados, Enclaves Fortificados teve também mais de uma etapa em seu processo de criação e produção, sendo a primeira cartográfica - a partir de percursos realizados entorno de condomínios residenciais. E, posteriormente, dentro do ateliê, com a produção do trabalho físico a partir dos dados coletados no espaço urbano.

Nas ruas, ao longo de 2017, foram realizadas séries de incursões em áreas públicas na região da Grande São Paulo, onde o modelo dos condomínios residenciais é hegemônico, a fim de observar que tipo de espaço público se constituía em seus arredores: as reverberações sociais, os códigos de conduta, as paisagens etc. Essa primeira etapa de pesquisa iniciou-se nas cidades de 
Barueri e Santana do Parnaíba e, em um segundo momento, concentrou-se na região do bairro do Morumbi, na cidade de São Paulo. No decorrer dessas etapas, uma incursão de contraponto socioeconômico foi também realizada na cidade de Diadema, na região do $A B C$ paulista, com o intuito de realizar uma cartografia mais diversa dos reflexos que a lógica dos condomínios produz no espaço urbano.

Nessa fase da pesquisa, além do próprio corpo como ferramenta uma câmera fotográfica e um aparelho smarthphone com aplicativo GPS foram utilizados para registrar os percursos ao redor dos muros dos condomínios - os quais muitas vezes tinham seus perímetros expandidos para o espaço público por meio de proibições de circulação impostas por agentes de segurança privada. A partir de tais circunstâncias e territórios, foram produzidos desenhos com dados de GPS em que a ponta do lápis era o corpo do caminhante e o papel o concreto das calçadas.

Nesse estágio, tornaram-se perceptíveis três tipos de limites existentes nos arredores dos condomínios: o físico, o

32 Para tais observações foram utilizadas as considerações sobre "limites im-positivos e com-positivos" 2018, p. 12

conceitual e 0 especular ${ }^{32}$. 0 limite físico, o mais evidente, é formado pela interdição matérica de muros e grades no espaço. 0 segundo limite observado se refere àqueles que expandiam o território privado para além das limitações físicas, são eles os limites conceituais, em que interdições no espaço são projetadas por meio da presença de seguranças ou ausência de transeuntes. Este tipo de limite fica evidente nas dificuldades criadas para se transitar próximo aos locais onde rondas de guardas particulares ocorrem, locais públicos em que pairam no ar proibições "onde é melhor não passar". De um modo geral, quase todos os entornos dos condomínios eram lugares onde a sensação do limite conceitual estava presente, pela

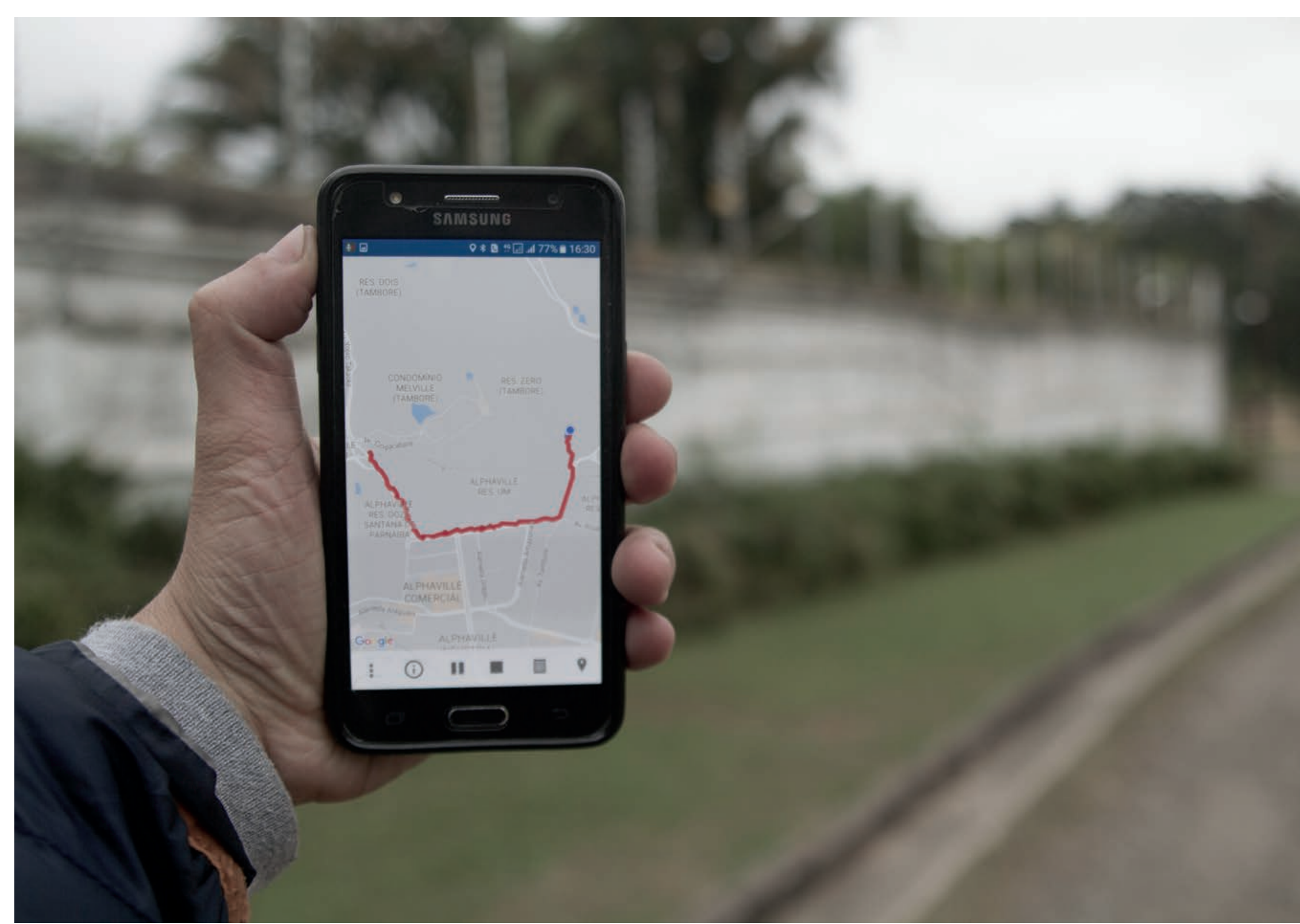


presença opressiva ou pela "desertificação" (segundo relatos de transeuntes, quando estes lugares estão esvaziados da presença humana é comum a sensação de insegurança pelo possível risco de assaltos). Por fim, o terceiro limite, o especular, que está diretamente associado ao segundo: tratase de limitar no espaço público a frequência daqueles que não espelham os modelos de aparência física dos que compõem o espaço privado dos condomínios. Ou seja, qualquer usuário do espaço público que não corresponda ao modelo do privado, torna-se um suspeito em potencial. De um modo geral, todas essas formas de limite se justapõem no espaço urbano.

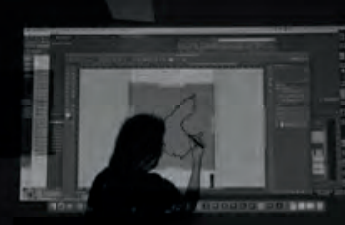

13
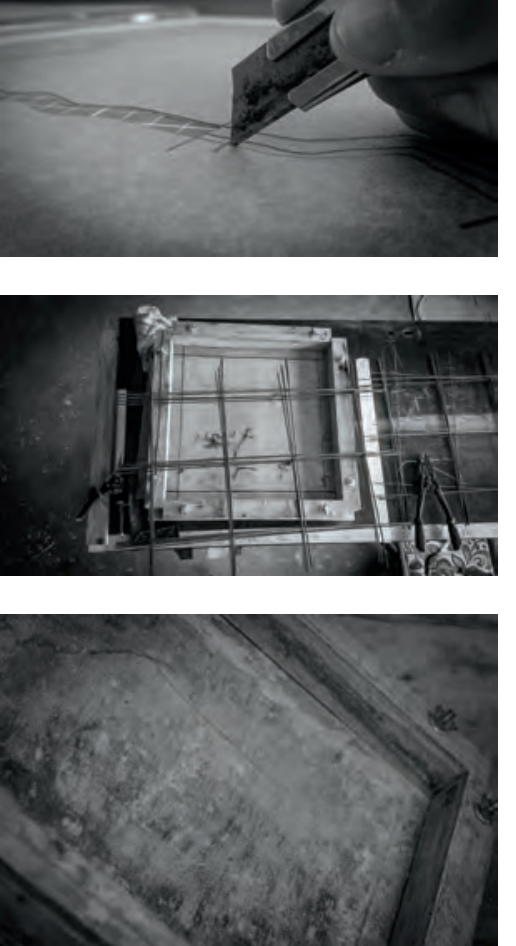

Após o estágio cartográfico nas ruas, a segunda etapa do trabalho dava-se no ateliê, com a transferência dos desenhos produzidos com os dados GPS para o papel cartão, com auxílio de um projetor digital de imagens. Posteriormente, esses traçados eram recortados com estilete, convertendo-se em moldes dos desenhos dos percursos a partir da técnica do estêncil. Nessa fase, também foram construídas 24 placas de concreto nas dimensões de $50 \times 50 \times 5 \mathrm{~cm}$ que, ao final do processo de produção, receberam os desenhos em jatos (spray) de tinta acrílica.

A escolha pela utilização do concreto e pela técnica do estêncil no trabalho ocorreram a partir da experiência cartográfica, tátil e óptica nas ruas, da aspereza dos muros dos condomínios e das pinturas em estêncil presentes nos caminhos percorridos. Ambas as escolhas também fazem referência ao caráter serial presente tanto nos moldes de madeira em que os módulos de concreto eram produzidos quanto à possibilidade de reprodução em série do estêncil. Características também presentes na lógica dos empreendimentos dos condomínios residenciais.
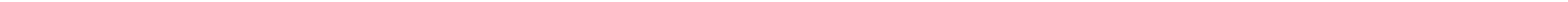


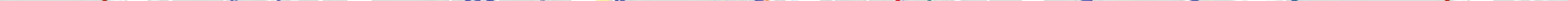




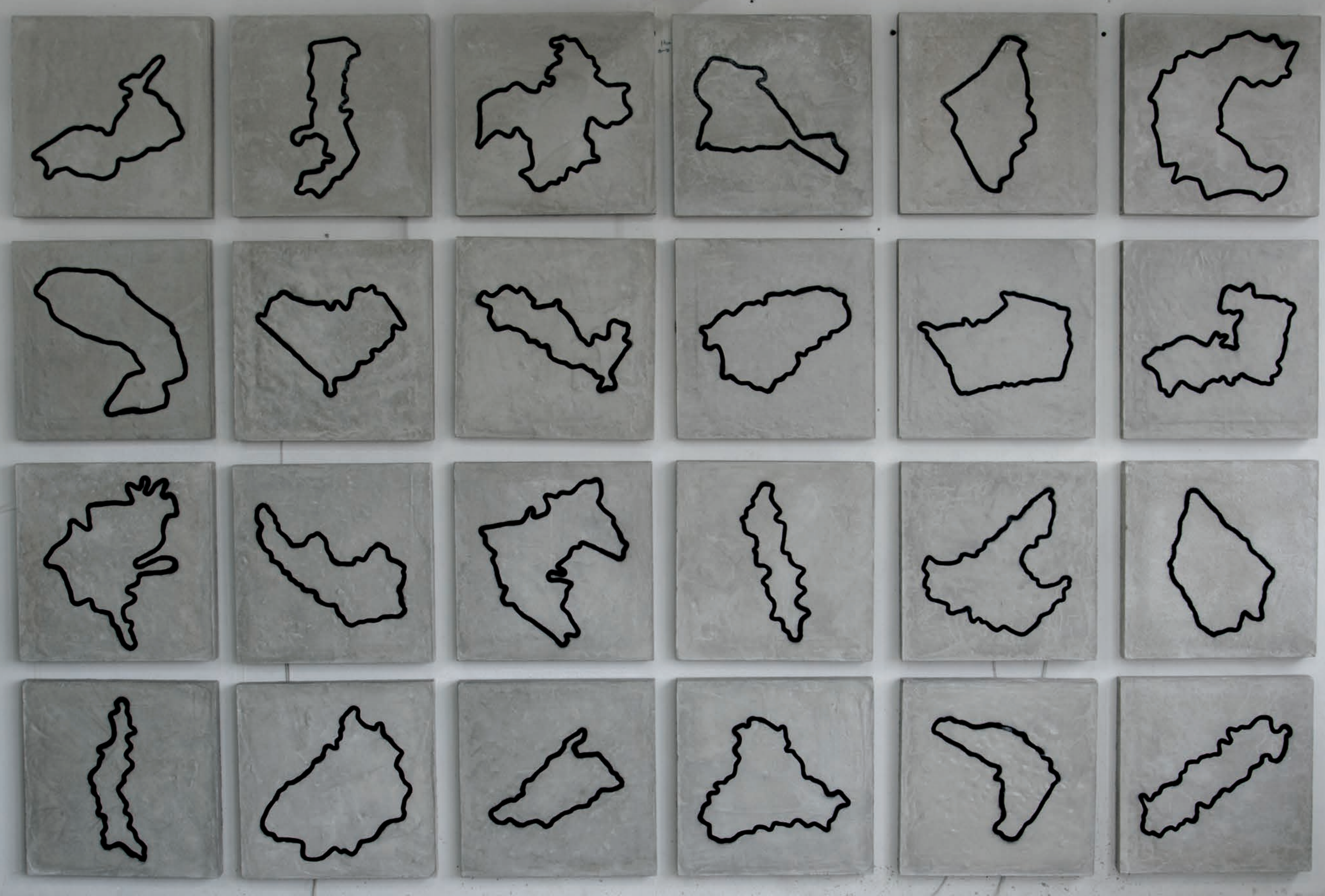


0 próprio nome Enclaves Fortificados, cunhado pela antropóloga Teresa Pires do Rio Caldeira, refere-se a um tipo de empreendimento imobiliário que ganhou força principalmente nos anos 1980 impulsionado pelo aumento das taxas de violência urbana em São Paulo, crescimento noticiado nos mesmos jornais em que se ofereciam soluções em formas de produtos, onde a segurança e o status de uma vida diferenciada nos condomínios, com serviços e equipamentos coletivos, eram os destaques.

Enclave, também na geografia política, é o nome dado a um território com distinções políticas, sociais e/ou culturais cujas fronteiras estão dentro de outro território. Terminologia condizente com a segregação produzida pelos condomínios fortificados em que o padrão de vida interno, regras e homogeneidade social, não condizem com as cidades nas quais são fundados.

Já 0 adjetivo "fortificado" advém das fortificações de guerra, dos locais protegidos e privilegiados para o ataque frente a inimigos, muito comuns na Antiguidade e Idade Média, na Ásia e Europa. Portanto, é a partir de tais conceitos que a sociedade atual nas cidades contemporâneas - se enclausura em condomínios, utilizando-se de arquiteturas belicosas que, por consequência, produzem formas sutis de hostilidade no cotidiano urbano.

Apesar dos contextos distintos, vejo similitudes entre a poética de Enclaves Fortificados e a performance The Green Line (2004) de Francis Alÿs, em que o artista percorre a linha verde do armistício de 1948 da guerra entre Israel e Jordânia, território atualmente ocupado pelo Estado de Israel e reivindicado pela Palestina desde a "Guerra dos seis dias", de 1967. Na ocasião da performance, Francis Alÿs percorreu durante dois dias a extensão de $24 \mathrm{~km}$ da linha traçada no mapa, despejando tinta verde no solo e produzindo um monumental rastro de tinta. Esse trabalho conta com um belo registro em vídeo, com o subtítulo "Às vezes, fazer algo de poético pode tornar-se político e, por vezes, fazer algo político pode tornar-se poético" ${ }^{33}$. Tendo em vista que o gesto poético de Enclaves Fortificados em torno dos condomínios se refere a questões da cidade e do espaço público tais percursos se tornam também eminentemente políticos.

A partir das questões geradas pelo trabalho Enclaves Fortificados passemos agora a algumas especificidades dos condomínios residenciais, destacando causas e efeitos gerados a partir desse modo particular de habitar as cidades contemporâneas.

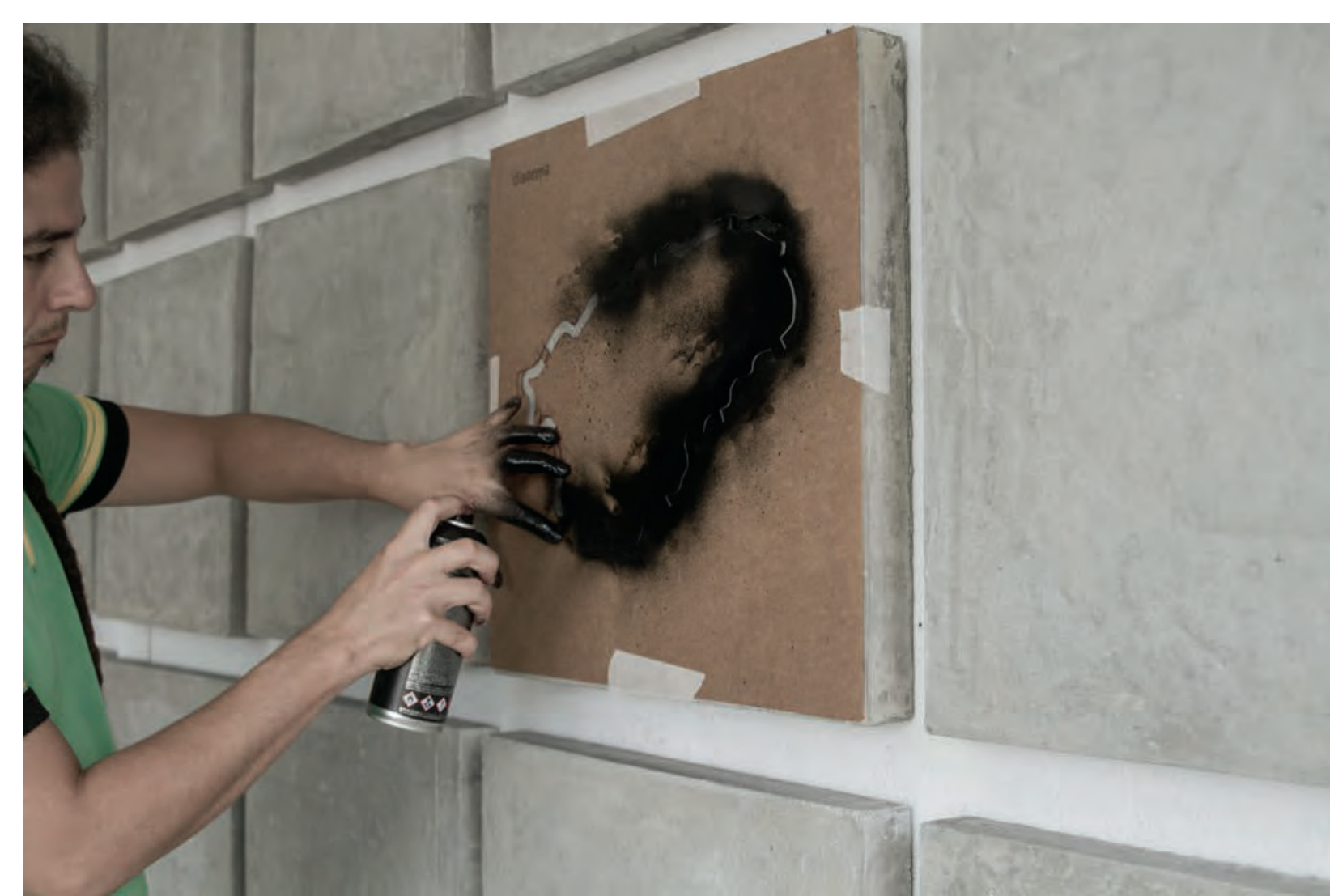




\section{3.}

279

\section{Enclausuramento modelo}

Os condomínios residenciais são fruto de uma rede diversa de agenciamentos de enunciação e reverberam signos, interesses e desejos em suas estruturas, ao mesmo tempo em que também atuam como máquinas de subjetivações parciais, como já referido anteriormente. Concentrar nossas atenções nesse fenômeno "mundial" nos auxiliará na investigação da constituição dos sujeitos contemporâneos. Para isso, pretendemos lançar luz a questões que levaram ao êxito esse novo modelo de habitar o espaço urbano para, em seguida, nos debruçarmos sobre os efeitos gerados por estes novos arranjos urbanos.

Em seu livro, Cidades de muros: Crimes, segregação e cidadania em São Paulo, a pesquisadora Teresa Pires do Rio Caldeira aponta que os condomínios na cidade de São Paulo existem desde 1928 mas que é na década de 1970 quando se deu um acréscimo de prédios de apartamentos residenciais. Tais empreendimentos integravam a rede urbana e a maioria estava concentrada em bairros centrais. Esse cenário sofreu grande alteração nas décadas de 1980 e 90 com um boom imobiliário que fez explodir o número de prédios, dando origem também a um novo tipo de residenciais, construídos em outras regiões da cidade, como é caso dos condomínios verticais do bairro Morumbi e também os condomínios horizontais de cidades vizinhas à capital, como Barueri e Santana do Parnaíba. Um fenômeno de "suburbanização" paulista aos moldes norte-americanos, onde as classes médias e altas preferem viver longe dos "problemas das cidades". A marca dessa nova fase de empreendimentos imobiliários não é 
só 0 aumento quantitativo, mas também qualitativo, pois agora os residenciais não integram a rede da cidade; ao contrário, de certa forma eles a negam ao se constituírem intramuros, possuindo uma ampla rede de serviços internos. Alphaville é um exemplo desse "novo modelo":

Alphaville é dividida em várias áreas residenciais muradas - cada uma enclausurada por muros de $3,5 \mathrm{~m}$ de altura e acessíveis apenas por entrada controlada -, um conjunto de edifícios de escritórios (Centro Empresarial) e um centro comercial ao redor de um shopping center (Centro Comercial). As primeiras partes a serem construídas, em meados dos anos 70, foram 0 centro de escritórios e duas áreas residenciais. No início dos anos 90 Alphaville tinha uma área urbanizada de $13 \mathrm{~km}^{2}$ e uma população fixa de cerca de 20 mil habitantes. 0 Centro Empresarial abrigava 360 empresas e o Centro Comercial, 600 empresas. (CALDEIRA, 2011, p. 263

Em 2013, o jornal inglês The Guardian produziu uma reportagem

34 Disponível em: www. theguardian.com/world/ wallsthelfast. Acesso em: 10 nov. 2017

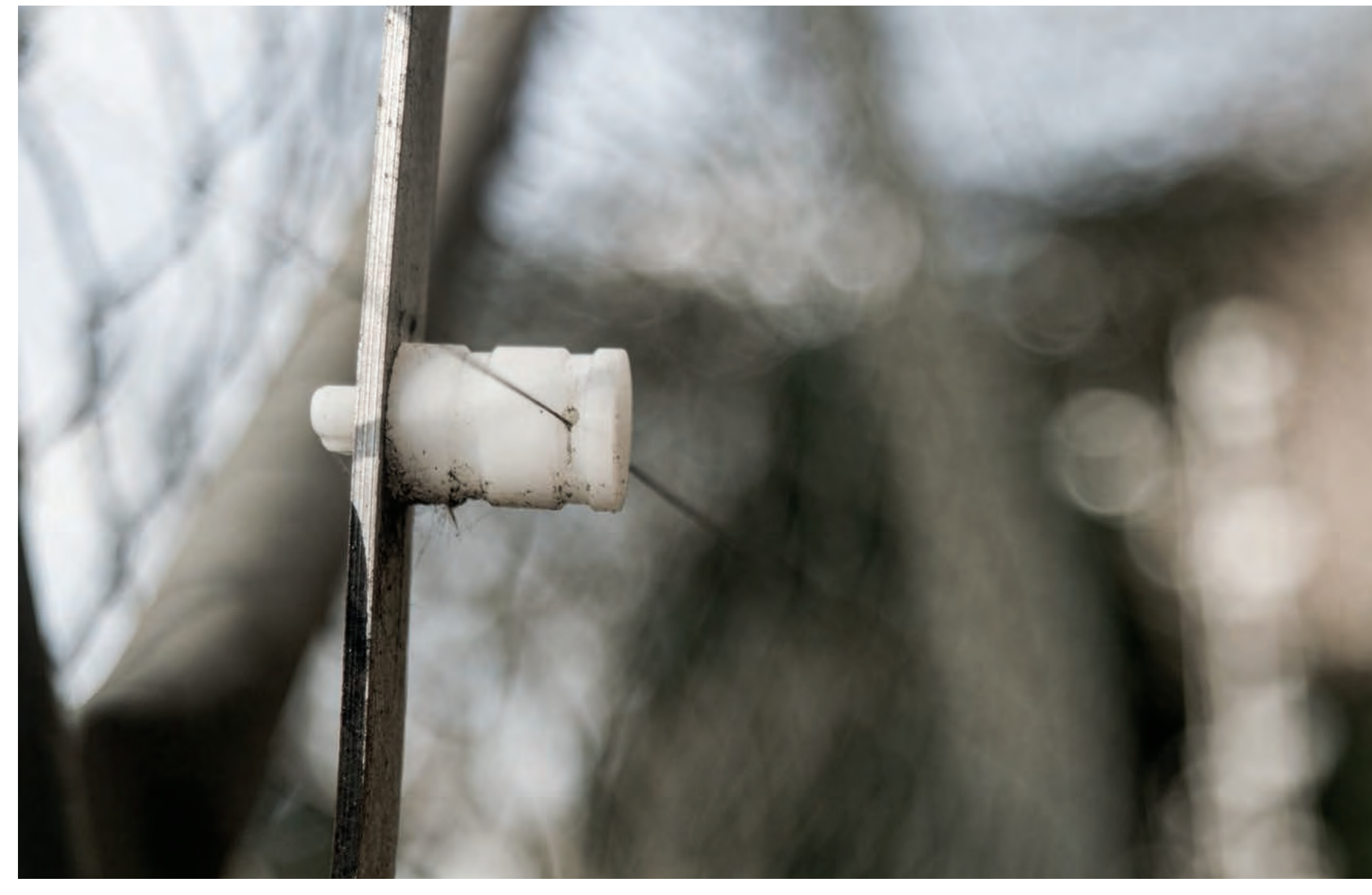

cercada nas cidades é a mesma: criar um mundo à parte, protegido da violência urbana e da heterogeneidade social que compõem o espaço público. Entretanto, tal modelo não vingou por acaso: as décadas de 1980 e 90 registram um aumento nas taxas de roubos e crimes violentos na região metropolitana de São Paulo. Aqueles que não foram marcados por experiências traumáticas viviam sob tensão das histórias disseminadas nos bairros - a "fala do crime", que contava muitas vezes com o auxílio sensacionalista da mídia para circular.
Seja em séries de condomínios de alto padrão ou em condomínios isolados, tanto verticais como horizontais, a lógica da vida segregação social e sociabilidade voltada para dentro. Nesse modelo, a segurança é um dos carros-chefes desse novo estilo de vida. Segundo consta, a segurança privada de Alphaville chegou a ter "800 homens e 80 veículos no início da década de 90" (CALDEIRA, 2011, p. 263) 
Nas ruas, uma estética da segurança aflorou nesse período as casas dos bairros, que até então possuíam muros baixos, passam tê-los levantados; igualmente, são instaladas grades de ferros nas janelas e trancas nas portas; multiplicam-se adornos como lanças de alumínio em portões de ferro, e cacos de vidro afixados sobre muros. Ou seja, zonas de conflitos passam a se enunciadas pela estética da segurança

Nos bairros ricos, o cenário não é diferente. Entretanto, no luga dos cacos de vidro, cercas eletrificadas compõem as paisagens, agentes de segurança privada assistem atentos aos passos dos transeuntes de dentro de guaritas - coletivas, nas calçadas, ou individuais, reconhecíveis por vidros blindados, nos muros das casas. A insegurança está instalada e os altos muros e as entradas monitoradas dos condomínios logo se tornam sonhos de consumo. Um círculo vicioso arma-se, um enorme aparelho de captura em que se propaga o medo com notícias e estatísticas enquanto soluções são vendidas à prestação; nada tão diferente dos dias atuais. Um exemplo robusto dos regimes semióticos já citados em Félix Guattari.

A máquina de subjetivação não para no medo, além da promessa da segurança, vendem-se também status e life-style, "os anúncios imobiliários constituem uma boa fonte de informação sobre estilos de vida e os valores das pessoas cujos desejos eles elaboram e ajudam a moldar" (CALDEIRA, 2011, p. 264). Atualmente, as peças publicitárias mais se parecem com jornais de formato tablóide com informações de eventos, design de interiores, alimentação, além de enumerações de vantagens dos serviços oferecidos nos intramuros anunciados.

Podemos compor duas imagens anacrônicas acerca dos condomínios atuais: a primeira é compará-los aos palacetes

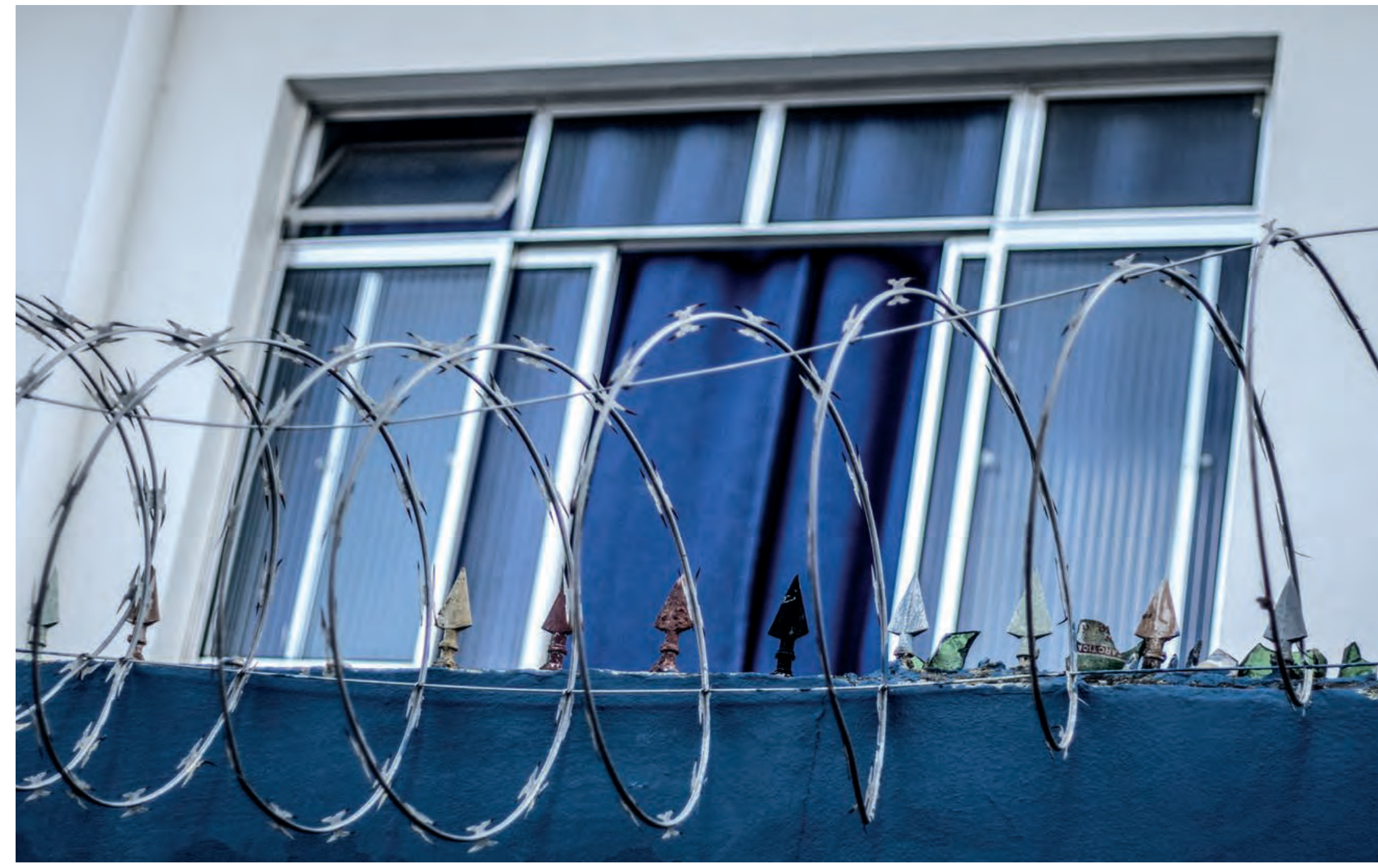

do Rococó, com seus palacianos que viviam apenas de palacetes em palacetes. Aliás, atualmente é possível encontra condomínios "batizados" com nomes aristocráticos em suas fachadas nos prédios do Morumbi. Outro paralelo seria compara as implantações territoriais dos condomínios às plantas dos castelos medievais, com suas fortalezas prontas para a guerra. Diante disso, e das características culturais, sociais e políticas limitadas destes espaços, Teresa Pires do Rio Caldeira propõe o conceito de enclaves fortificados: 
Os condomínios fechados são a versão residencial de uma categoria mais ampla de novos empreendimentos urbanos que chamo de enclaves fortificados. Eles estão mudando consideravelmente a maneira como as pessoas das classes média e alta vivem consomem, trabalham e gastam seu tempo de lazer. Eles estão mudando 0 panorama das cidades, seu padrão de segregação espacial e o caráter do espaço público e das interações públicas entres as classes. Os enclaves fortificados incluem conjuntos de escritórios, shopping centers, e cada vez mais outros espaços que têm sido adaptados para se conformarem a esse modelo, como escolas, hospitais, centros de lazer e parques temáticos. Todos os tipos de enclaves fortificados partilham algumas características básicas. São propriedade privada para o uso coletivo e enfatizam o valor do que é privado e restrito ao mesmo tempo que desvalorizam o que é público e aberto na cidade. São fisicamente demarcados e isolados por muros, grades, espaços vazios e detalhes arquitetônicos. São voltados para 0 interior e não em direção à rua, cuja vida pública rejeitam explicitamente. São controlados por guardas armados e sistemas de segurança, que impõem as regras de inclusão e exclusão. São flexíveis: devido ao seu tamanho, às novas tecnologias de comunicação, organização do trabalho e aos sistemas de segurança, eles são espaços autônomos, independentes do seu entorno, que podem ser situados praticamente em qualquer lugar. Em outras palavras, em contraste com formas anteriores de empreendimentos comerciais e residenciais, eles pertencem não aos seus arredores imediatos, mas a redes invisíveis. Em consequência, embora tendam a ser espaços para as classes altas, podem ser situados em áreas rurais ou na periferia, ao lado de favelas ou casas autoconstruídas. Finalmente, os enclaves tendem a ser ambientes socialmente homogêneos. Aqueles que escolhem habitar esses espaços valorizam viver entre pessoas seletas (ou seja, do mesmo grupo social) e longe das interações indesejadas, movimento, heterogeneidade, perigo e imprevisibilidade das ruas. Os enclaves privados e fortificados cultivam um relacionamento de negação e ruptura com o resto da cidade e com o que pode ser chamado de um estilo moderno de espaço público aberto à livre circulação. Eles estão transformando a natureza do espaço público e a qualidade das interações públicas na cidade, que estão se tornando cada vez mais marcadas por suspeita e restrição

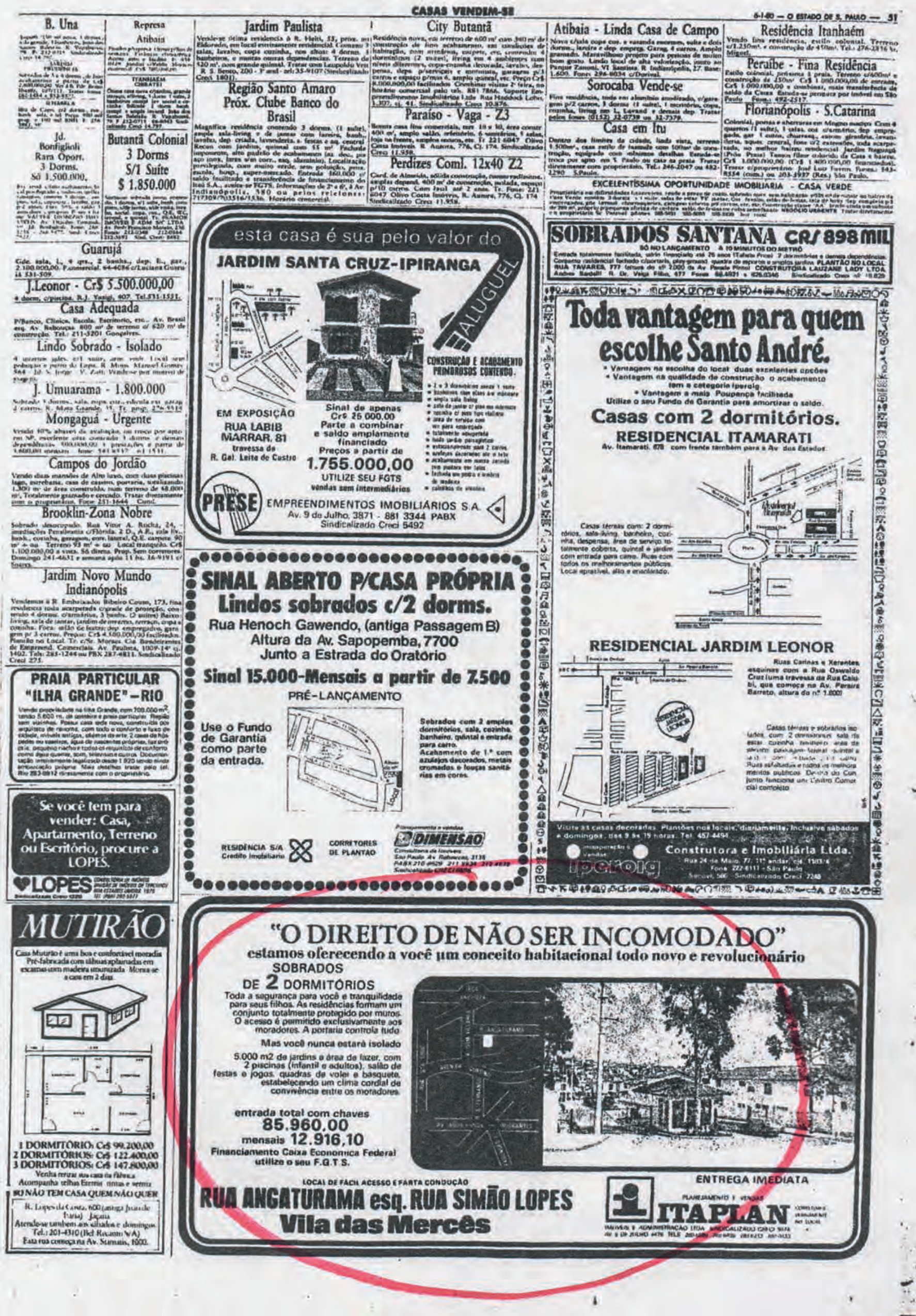


Os enclaves fortificados conferem status. A construção de símbolos de status é um processo que elabora diferenças sociais e cria meios para a afirmação de distância e desigualdade sociais. Os enclaves são literais na sua criação de separação. São claramente demarcados por todos os tipos de barreiras físicas e artifícios de distanciamento e sua presença no espaço da cidade é uma evidente afirmação de diferenciação social. Eles oferecem uma nova maneira de estabelecer fronteiras entre grupos sociais, criando novas hierarquias entre eles $\mathrm{e}$, portanto, organizando explicitamente as diferenças como desigualdade. 0 uso de meios literais de separação é complementado por uma elaboração simbólica que transforma enclausuramento, isolamento, restrição e vigilância em símbolos de status. (CALDEIRA, 2011, p. 258-259)

A lógica privada dos enclaves fortificados é um emaranhado de semióticas significantes e assiginificantes, produtoras de subjetivação em diversos níveis. E não só para aqueles que estão dentro de seus territórios homogêneos, pois também expande sua influência aos seus entornos, constituindo novos espaços, lugares e sujeitos.

Os mesmos muros que protegem os indivíduos nas interioridades dos enclaves, geram efeitos contrários em suas exterioridades criando ambientes inseguros com o esvaziamento humano das paisagens em que quase não há circulação nas calçadas porque não existem incentivos para tal, como por exemplo uma malha urbana de serviços nas regiões que motivem as pessoas a circularem em tais localidades. Desse modo, não existem os "olhos das ruas" mencionados por Jane Jacobs (JACOBS, 2011, p. 35) em que nos bairros de calçadas movimentadas existe automaticamente uma proteção recíproca entre os transeuntes, gerada a partir de suas presenças.
Em tal contexto, todos aqueles que advêm do exterior e não se assemelham aos padrões internos são suspeitos aos olhos dos seguranças privados, que observam os transeuntes ao fazerem rondas em volta dos muros ou assistem os pedestres pelas câmeras de vigilância. No romance Estorvo, Chico Buarque apresenta uma imagem que ilustra esta subjetividade em que 0 diferente é suspeito:

O vigia na guarita fortificada é novo no serviço, e tem a obrigação de me barrar no condomínio. Pergunta meu nome e destino, observando os meus sapatos. Interfona para a casa 16 e diz que há um cidadão dizendo que é irmão da dona da casa. A casa 16 responde alguma coisa e o vigia não gosta e faz "hum". 0 portão de grades de ferro verde e argolões dourados abre-se aos pequenos trancos, como que relutando em me dar passagem. 0 vigia me vê subindo a ladeira, repara nas minhas solas, e acredita que eu seja o primeiro pedestre autorizado a transpor aquele portão. A casa 16, no final do condomínio, tem outro interfone, ou outro portão eletrônico e dois seguranças armados. Os cães ladram em coro e param de ladrar de estalo. Um rapaz de flanela na mão abre a portinhola lateral e me faz entrar no jardim com um gesto de flanela. (...)

0 empregado não sabe que porta da casa eu mereço, pois não vim fazer entrega nem tenho aspecto de visita. Para, torce a flanela para escoar a dúvida, e decide-se pela porta da garagem, que não é aqui nem lá. Obedecendo a sinais convulsos da flanela, contorno os automóveis na garagem transparente, subo por uma escada em caracol, e dou numa espécie de sala de estar com pé-direito descomunal, piso de granito, parede inclinada de vidro, outras paredes brancas e nuas, muito eco, uma sala de estar onde nunca vi ninguém sentado. À esquerda dessa sala corre a grande escada que vem do segundo andar. E ao pé da grande escada há uma salinha que eles chamam de jardim de inverno, anexa ao pátio interno onde vivia o fícus. Eis minha irmã de peignoir, tomando café da manhã numa mesa oval." (BUARQUE, 1991, p. 14-16) 
Os enclaves são exemplos das práticas divisórias de Foucault e reproduzem 0 modo indivíduo em funcionários, visitantes e transeuntes, que estão à mercê dos padrões de classificação de moradores e empregados. Quando o funcionário do romance de Chico Buarque vacila diante do visitante, não o faz por acaso pois as aparências reproduzem os códigos do status quo que as portas específicas do texto explicitam.

No entanto, o efeito mais problemático dos enclaves é quando sua lógica se expande ao espaço público, minando a concepção da modernidade de espaço aberto e igualitário, em que o anonimato das multidões heterogêneas cunhava a noção democrática $e$ fluída de espaço público. Na medida em que grande parte da população isola-se nos enclaves, evitando a vida pública da cidade, o espaço público também se torna menos heterogêneo e as ruas tornam-se estigmatizadas, onde 0 outro passa a se uma ameaça devido ao temor da violência urbana. Assim, a população de modo geral caminha menos nos espaços públicos e quase não sai por eles à noite, o espaço público torna-se restrito, constituído de zonas ameaçadoras.

A lógica palaciana dos enclaves generaliza-se, as imagens de senhores e senhoras bem vestidos, olhando vitrines, indo aos cinemas e passeando pelos centros agora restringem-se às fotografias do início do século passado. Os sujeitos urbanos agora circulam de enclaves em enclaves, os passeios das rua foram trocados pelos corredores dos shoppings, o espaço público torna-se apenas local de passagem e não mais de encontros.

A nova sociabilidade urbana acontece emoldurada por muros, segregando as classes sociais do convívio, um apartheid brando que destrói a noção do comum como afirmação das diferenças. As cidades cada vez tornam-se mais controladas, com fronteiras fixas e restrições; em suma, reproduções de enclaves, onde se transferem as atividades dos espaços públicos heterogêneos para espaços privados socialmente homogêneos, impossibilitando as interações e a tolerância ao diferente. Felizmente, esse retrato urbano não está totalmente completo, pois ainda existem "calçadões", praças e parques que fazem jus ao ideário de espaço público da modernidade, embora a cada dia mais praças estejam sendo cercadas e os parques, tornando-se alvos de grupos econômicos privados.

Em meio a tais paisagens e agenciamentos de enunciação, os sujeitos urbanos se constituem. Cada vez mais ensimesmados e intolerantes às diferenças, recusando consciente ou inconscientemente a noção de público em favor do privado. Podemos ver tais reflexos nas iniciativas comunitárias de bairros das classes média e baixa, que fecham suas ruas com cancelas e portões em nome da "segurança coletiva" e equivocadamente apropriam-se do espaço público. Ou até mesmo em intolerâncias e demonstrações de ódio às diferenças nas redes sociais - que por sua vez, também formam enclaves (virtuais), na medida em que são espaços privados de uso público e possuem regras próprias. Por fim, não podemos esquecer que a lógica dos enclaves é paralela à ideologia neoliberal, que mina serviços públicos como educação, saúde, segurança, entre outros com o intuito de privatizar e transformar direitos obtidos em mercadorias para aqueles que possuem poderio aquisitivo. Problematiza os enclaves fortificados é, portanto, olhar criticamente para uma série de agenciamentos de enunciação que atualmente modificam a histórica noção de espaço público e de produção do comum, tanto no plano material como na subjetividade dos sujeitos urbanos contemporâneos. 


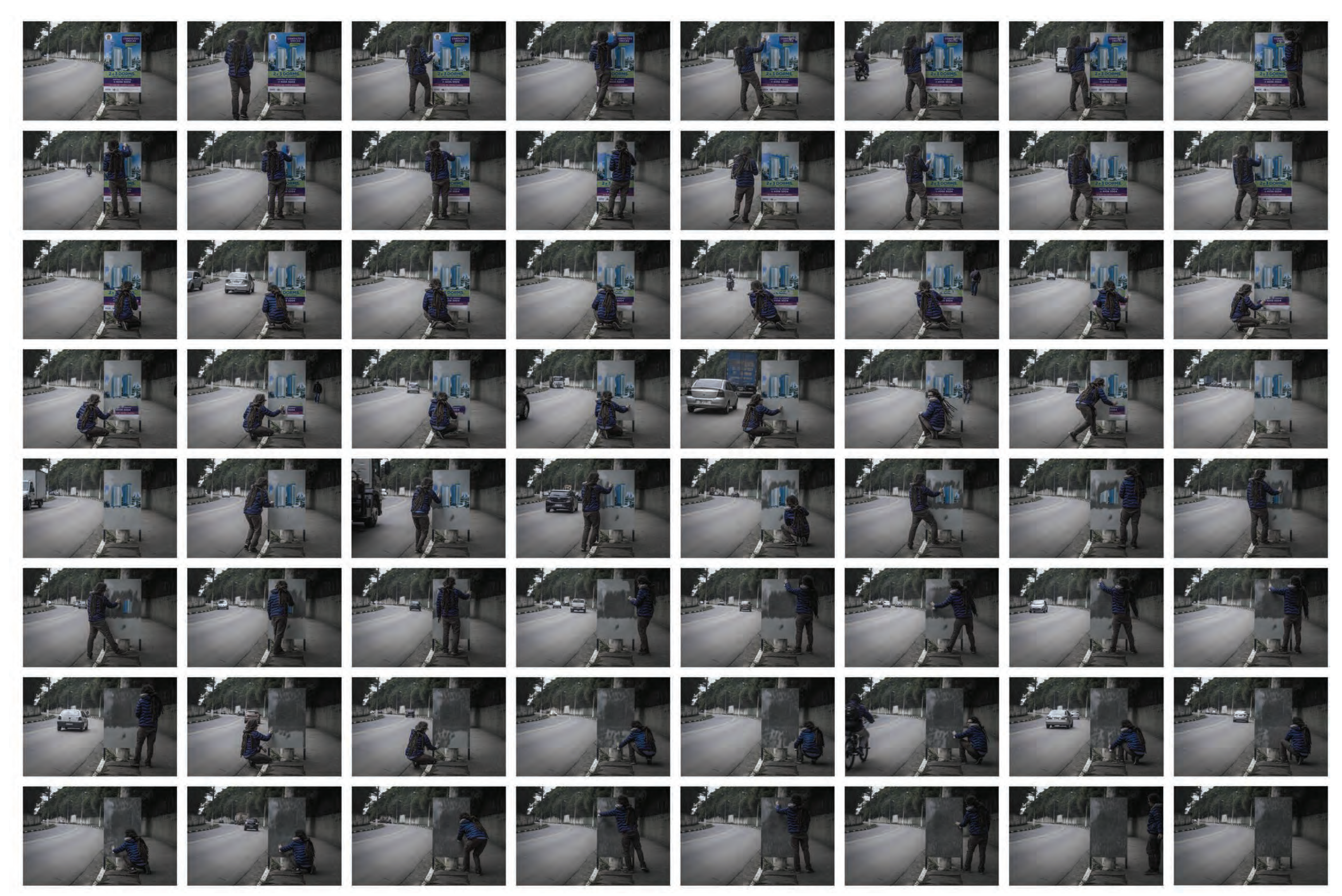




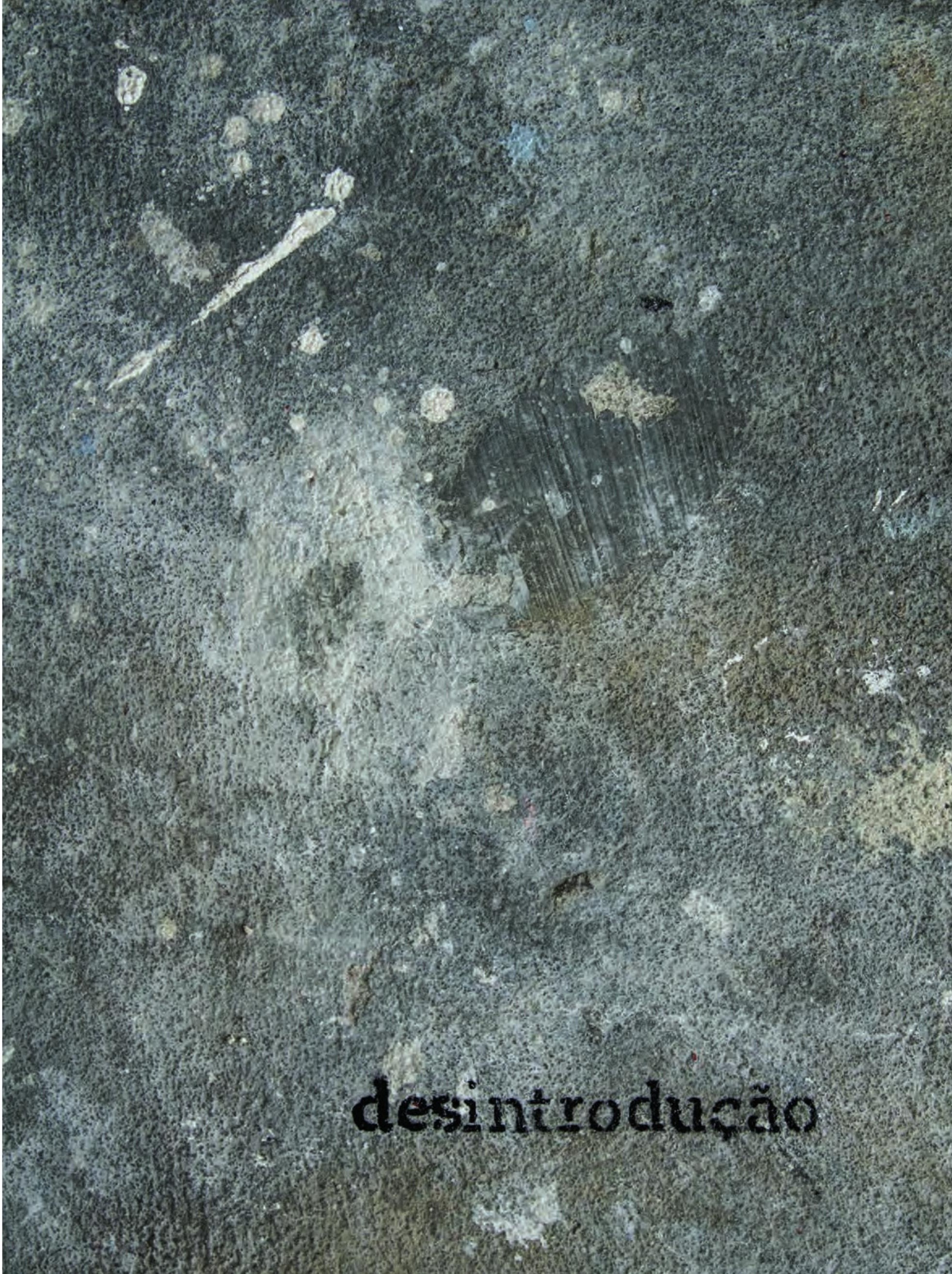


Chegamos ao final do percurso desta dissertação, e cabe-me colocar as últimas palavras, esboçar uma conclusão para a pesquisa. Mas seria isso possível? Concluir?

Antes de qualquer coisa, gostaria de informar que abandonarei aqui a primeira pessoa do plural que utilizei ao longo de todos os outros textos, uma escolha que embora possa ter soado estranha em alguns momentos (considerando-se uma dissertação em Poéticas Visuais quase como um relato de processos), digo que esse foi o modo mais confortável que encontrei para dar conta dos múltiplos que habitam em mim, além também de fazer jus às conversas com minha orientadora, amigos e autores.

Utilizo o nome "Desintrodução" para este texto final, pois considero que todos os capítulos anteriores não fizeram outra coisa senão introduzir o leitor à pesquisa, apresentando questões e conceitos que atravessam os trabalhos poéticos de modo transversal.

Assim, do início ao fim, esta dissertação é um compartilhamento de uma série de inquietações e expressa um desejo de pensar sobre os diversos modos em que o espaço efetua processos de subjetivação nos sujeitos urbanos. 
Todos os trabalhos aqui apresentados também podem ser vistos como reações frente às sensações e sentidos que a cidade produz, reações éticas, em que a vida grita contra imposições que conformam sujeitos a viverem com horizontes interrompidos ou a percorrerem caminhos determinados. Lembro-me que antes de produzir o trabalho Janelas, sentia algo como uma espécie de claustrofobia, um desejo de horizontes que me fez saltar muros para fotografar o que havia por detrás deles e depois produzir intervenções para compartilhar tais inquietações com o mundo. Mesmo desejo que também me fez perambular durante meses pela Grande São Paulo, em busca de experiências estéticas, ao constatar o constante anestesiamento da vida nas cidades que as resume em trajetos funcionais.

Embora muitas vezes eu seja tomado por um "espírito quixotesco", tanto nas palavras quanto nas atitudes, não pretendo que as experimentações poéticas sejam dispositivos de denúncia ou algo semelhante; longe disso, meu desejo é propor questões, colocar sob suspeita a cidade como máquina de subjetivação, por meio de blocos de sensações.

Sinto ser necessário aqui também apontar algumas "evoluções" que considero importantes à pesquisa (diferenciações de potências), sobretudo entre alguns procedimentos adotados. A começar pela passagem da série Janelas (2014) para as Paisagens Esculpidas (2016 e 2017), em que senti ser necessário saturar o gesto performático para discutir o problema dos muros de um modo mais incisivo, pois as fotografias estáticas das intervenções urbanas de Janelas, por sua natureza, suscitavam dúvidas em relação ao processo de construção dos trabalhos ("É photoshop?", perguntaram-me diversas vezes). Mesmo sempre achando boas as dúvidas e as ambiguidades ao redor do trabalho - como se houvesse algo a ser decifrado pelo espectador -, sentia algum débito no plano das sensações, pois considerava que o trabalho não deveria pertencer apenas à esfera da contemplação. Assim com tais reflexões a posteriori, decidi frisar o gesto performático da intervenção urbana com os vídeos das Paisagens Esculpidas, para "melhor" aproximar os trabalhos das sensações que pretendia.

Considero um erro hierarquizar operações poéticas e trabalhos, pois cada um deles é um ser de sensação composto de singularidades. Entretanto, também sinto ser adequado compartilhar os caminhos e descaminhos da pesquisa, pois ignorar ou omitir as novas escolhas geradas a partir dos trabalhos anteriores, parece-me um pouco contraproducente em se tratando de uma abertura de processos.

Ainda no plano dos movimentos da pesquisa, hoje consigo distinguir duas fases cartográficas no espaço urbano ocorridas com as errâncias realizadas na produção da série Fragmentos (2015) e nos processos do trabalho Enclaves Fortificados (2018). Variações que marcam diferenças sobre a compreensão do fazer cartográfico.

Nas errâncias empreendidas na fase de Fragmentos, busquei investigar as sensações que o espaço urbano provocava em mim (muito inspirado nas deambulações surrealistas e nas derivas situacionistas). Posso dizer que foi uma fase experimental centrada em uma perspectiva muito subjetiva das afecções geradas pela lentidão pedestre e desorientação espacial, ou seja, eram como cartografias dos movimentos de um sujeito em busca de experiências desubjetivantes, de alteridade no espaço urbano, e que, para compartilhar o sensível ao qual tinha acesso, produzia fotografias e coletava objetos das ruas. 
Já nos processos de Enclaves Fortificados, o que me moveu foi

querer cartografar as qualidades do espaço urbano que afetam o contexto social e engendram a vida urbana de um modo mais amplo. Assim, os medos, os prazeres, entre outros sentimentos e sensações que o espaço me despertou na fase anterior, passaram a compor as novas observações sobre os padrões que coincidiam nas paisagens. $E$, nessa fase, novamente havia um muro à minha frente; no entanto, ao invés de bloquear, me possibilitou prestar atenção à "lógica dos condomínios", levando-me a observar não apenas os limites físicos do espaço, mas também os que se projetam para além das estruturas matéricas.

Os desenhos dos Enclaves Fortificados dão visualidade a isso a que me refiro, pois acompanham as nuances das paisagens ao redor dos condomínios, linhas que registram mais que as fronteiras rígidas das implantações territoriais - elas traduzem também os fluxos dos percursos, configurando-se como cartografias do espaço/sujeito, aproximando o trabalho ao que Blanchot chamaria de "eu-neutro" da literatura, em que o texto fala através do "ser da linguagem" e possibilita uma "experiência do fora". Assim, penso que os desenhos de Enclaves Fortificados também podem ser lidos como o espaço se expressando ao ser praticado.

Por fim, apesar de ter destacado algumas linhas de força e movimentos ao longo desta dissertação, ela não se conclui , pois ainda está em movimento, em devir... 
Créditos das fotos

Lista de figuras

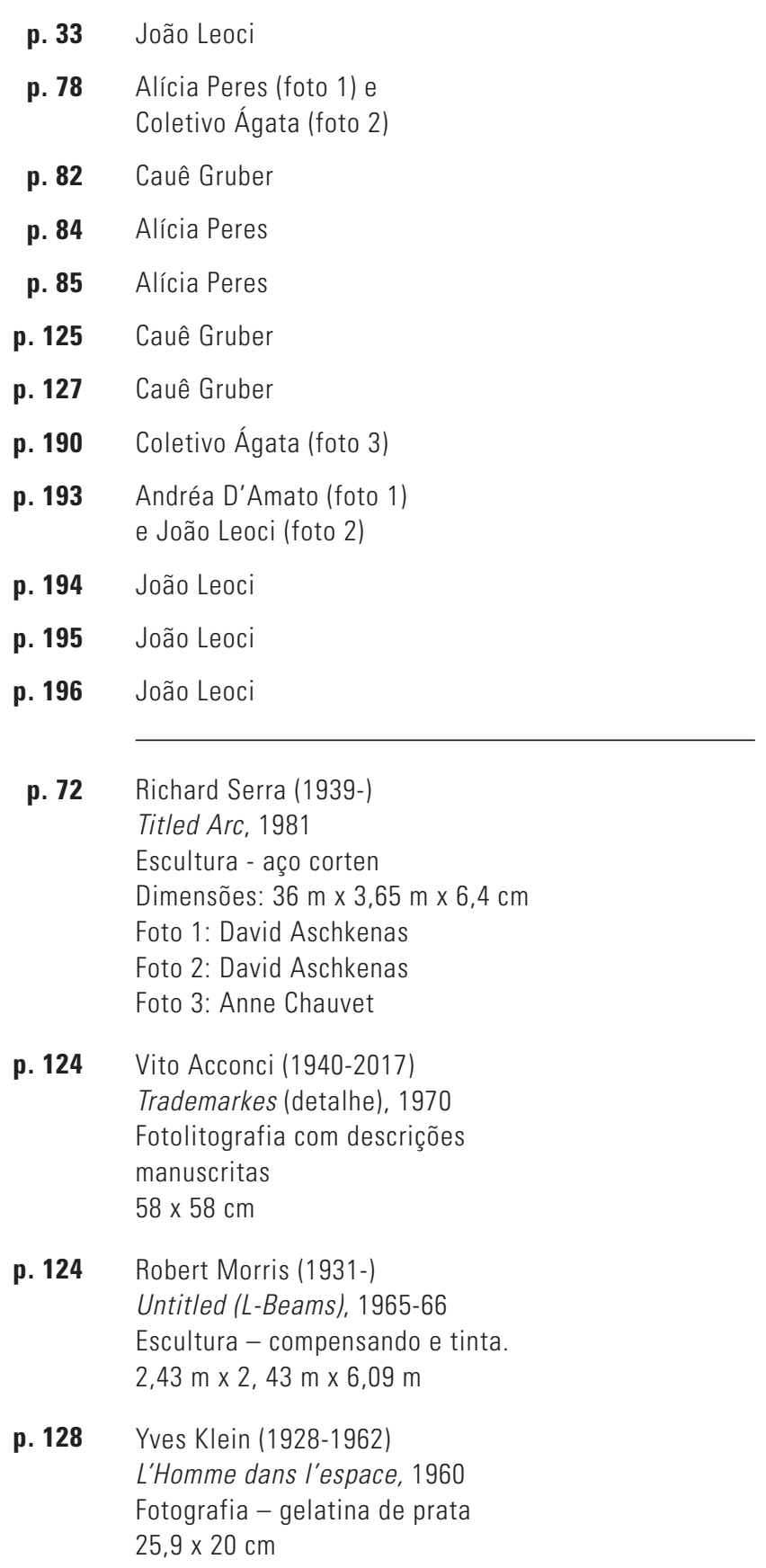

*Fotos numeradas da

esquerda para direita $\mathrm{e}$

oma para baixo na

em em que aparecen.

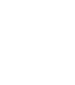


p. 145 Gordon Matta-Clark (1943-1978) Conical Intersect, 1975

mpressão fotográfica (detalhes), 1977

Fotografia - gelatina de prata.

$101,9 \times 76,2 \mathrm{~cm}$

p. 172 André Breton (1896-1966) e Tristan Tzara (1896-1963) Excusions \& Visites dada / Premiere Visite, 192 Cartaz

$$
21.3 \times 127,7 \mathrm{~cm}
$$

p. 172 Autor não identificado

Excursion et visite dada à Saint-Julien-Le-Pauvre, 192 $11 \times 16,5 \mathrm{~cm}$

p. 174 Internacional Situacionista (1957-1972) Capa de edicão francesa n 1, 1958 32 páginas

p. 176 Guy Debord (1931-1994)

Guide Psychogéographique de Paris: Discours sur les passions de l'amour: Pentes psychogéographiques de la derive et localisation d'unités d'ambience, 1957 Litografia sobre papel

$59,4 \times 73,8 \mathrm{~cm}$

p. 203 Paul-Henry Chombart de Lauwe (1913-1998) Releve de tours les trajets effectues em um na par une etudiante habitant le XVI Arrondissement.

Publicado em Paris et l agglomeration parisiense.

Lespace social das une grande cité - Methodes de

recherches pour l'étude d'une grande cité, PUF, 1952.

p. 276 Francis Alÿs (1959-)

Still de The Green Line (Sometimes doing something poetic can become political and sometimes doing Registro polideo can beco 17 minutos e 41 segundos.

p. 285 Jornal O Estado de São Paulo.

6 de janeiro de 1980

Página 51.
ARENDT, Hannah. A condição humana. Rio de Janeiro: ForenseUniversitária, 1983

AGAMBEN, Giorgio. 0 que é o contemporâneo? e outros ensaios. Chapecó: Argos, 2009

AUMONT, Jacques. 0 olho interminável - cinema e pintura. São Paulo: Cosac \& Naify, 2004.

AUSLANDER, Philip. A performatividade da documentação de performance. eRevista Performatus, ano 2, n. 7, nov. 2013. Disponíve em: <https://performatus.net/traducoes/perf-doc-perf/>. Acesso em 10 jan. 2016.

BAPTISTA, Luis Antonio. A cidade dos sábios - Reflexões sobre a dinâmica social nas grandes cidades. São Paulo: Summus, 1999.

BARTALINI, Vladimir. Arte e paisagem: uma união instável e sempre renovada. Arquitextos, São Paulo, ano 09, n. 097, Vitruvius, jun. 2008. Disponível em:<http://www.vitruvius.com.br/revistas/ read/arquitextos/09.097/133> Acesso em: 20 maio 2018.

BARTHES, Roland. A câmara clara, notas sobre a fotografia. Rio de Janeiro: Nova Fronteira, 1984.

BENJAMIN, Walter. Obras escolhidas - Magia e técnica, arte e política. São Paulo: Brasiliense, 1985.

BEY Hakim. TAZ: Zona Autônoma Temporária. São Paulo: Conrad 2001.

BONDIA, Jorge Larrosa. Notas sobre a experiência e o saber de experiência. Rev. Bras. Educ. 2002, n.19, pp. 20-28. Disponível em: $<$ http://www.scielo.br/pdf/rbedu/n19/n19a02.pdf >. Acesso em: 13 de outubro de 2016. 
1991.

CALVINO, Italo. As cidades invisíveis. Rio de Janeiro: 0 Globo; Folha de São Paulo, 2003

CALDEIRA, Teresa Pires do Rio. Cidade de muros: crime, segregação e cidadania em São Paulo. Editora 34, 2011.

CA0, Santiago. Cartografias sensíveis em espaços públicos 2018. Disponível em: <http://santiagocao.metzonimia.com/ cartografias-sensiveis>. Acesso em: 22 maio 2018.

CARERI, Francesco. Walkscapes - 0 caminhar como prática estética. São Paulo: Editora G. Gili, 2013.

CERTEAU, Michel de. A invenção do cotidiano: 1. Artes de fazer. Petrópolis: Vozes, 2014.

COTRIM, Cecilia; FERREIRA, Glória (orgs.). Escritos de artistas: anos 60/70. Rio de Janeiro: Zahar, 2006.

CUEVAS, Tatiana; RANGEL, Gabriela (orgs.). Desfazendo 0 espaço - Gordon Matta-Clark. São Paulo: MAMSP, 2010

DELEUZE, Gilles. Foucault. Lisboa: Edições 70, 2015.

. Lógica do sentido. São Paulo: Perspectiva, 2015.

DELEUZE, Gilles; GUATTARI, Félix. Mil Platôs. Volume 3. São Paulo: Editora 34, 1996.

DELEUZE, Gilles; GUATTARI, Félix. Mil Platôs. Volume 5. São Paulo: Editora 34, 1997

DELEUZE, Gilles; GUATTARI, Félix. 0 que é a filosofia? São Paulo: Editora 34, 1992.

EISLER, Riane. 0 cálice e a espada - Nosso passado, nosso futuro. São Paulo: Palas Athena, 2007.

ESPINOSA, Baruch. Ética. São Paulo: EDUSP, 2015.
FONSECA, Márcio Alves da. Michel Foucault e a constituição do sujeito. São Paulo: EDUC, 2016

FOUCAULT, Michel. De outros espaços. Trad. de Pedro Moura 1998. Disponível em: <http://www.virose.pt/vector/periferia/ foucault_pt.html>. Acesso em: 13 maio 2018.

2013.

0 corpo utópico; as heterotopias. São Paulo: n-1 edições,

FOUCAULT, Michel. 0 sujeito e o poder. In: DREYFUS, Hubert L. RABINOW, Paul L. Michel Foucault: uma trajetória filosófica para além do estruturalismo e da hermenêutica. Rio de Janeiro: ForenseUniversitária, 1995

GUATTARI, Félix. As três ecologias. Campinas: Papirus, 2012.

Caosmose - um novo paradigma estético. São Paulo: Editora 34, 2012

. Da produção de subjetividade. In: PARENTE, André (org.). Imagem-máquina: a era das tecnologias do virtual. Rio de Janeiro Editora 34, 1993.

GUATTARI, Félix; ROLNIK, Suely. Cartografias do desejo. Rio de Janeiro: Vozes, 1986

GUATTARI, Félix; ROLNIK, Suely. Micropolítica: Cartografias do desejo. Petrópolis: Vozes, 2000.

JACOBS, Jane. Morte e vida nas grandes cidades. São Paulo: WMF; Martins Fontes, 2011

JACQUES, Paola Bereinstein. Elogio aos errantes. Salvador: EDUFBA, 2014.

(org.). Apologia da deriva: escritos situacionistas sobre a cidade / Internacional Situacionista. Rio de Janeiro: Casa da Palavra, 2003.

LAZZARAT0, Maurizio. Signos, máquina, subjetividades. São 
Paulo: SESC; n-1 edições, 2014

LEVY, Tatiana Salem. A experiência do fora: Blanchot, Foucault e Deleuze. Rio de Janeiro: Civilização Brasileira, 2011.

MOUFFE, Chantal. Prácticas artísticas y democracia agonística Barcelona: Universitat Autònoma de Barcelona, 2007.

O’DOHERTY, Brian. No interior do cubo branco: a ideologia do espaço da arte. São Paulo: Martins Fontes, 2002.

PALLAMIN, Vera M. Cidade e cultura: esfera pública e transformação urbana. São Paulo: Estação Liberdade, 2002.

PEIXOTO, Nelson Brissac. Paisagens urbanas. São Paulo: Editora Senac São Paulo: Editora Marca D’água. 1996.

PELBART, Peter Pál. 0 avesso do niilismo: cartografias do esgotamento. São Paulo: n-1 edições, 2013.

PHELAN, Peggy. Unmarked, The politics of performance. London/ NY: Routledge, 1996

POZZANA, Laura. A formação do cartógrafo é o mundo: corporificação e afetabilidade. Fractal - Revista de Psicologia, v. 25, n. 2, p. 323-338, 2013.

QUIROGA, Daniele Neves. 0 desvelar de pontencialidades entre a performance e a fotografia-documento. In: XII Seminário de História da Arte, 2013, Pelotas. XII Seminário de História da Arte - Centro de Artes - UFPel, 2013. v. 03. Disponível em: <https://periodicos.ufpel. edu.br/ojs2/index.php/Arte/article/view/3012/2593>. Acesso em: 13 de outubro de 2016

ROUILLÉ, André. A fotografia: entre documento e a arte contemporânea. São Paulo: Senac, 2009.

ROLNIK, Suely. Cartografia sentimental: transformações contemporâneas do desejo. Porto Alegre: Sulina; Editora da UFRGS, 2011.
ROSE, Nikolas. Inventando nossos eus. In: SILVA, Tomaz Tadeu da (org.). Nunca fomos humanos - nos rastros do sujeito. Belo Horizonte: Autêntica, 2001

SANTOS, Milton. A natureza do espaço: técnica e tempo, razão e emoção. São Paulo: EDUSP, 2009.

WARBURG, Aby. Atlas Mnemosyne. Madrid: Akal, 2010 


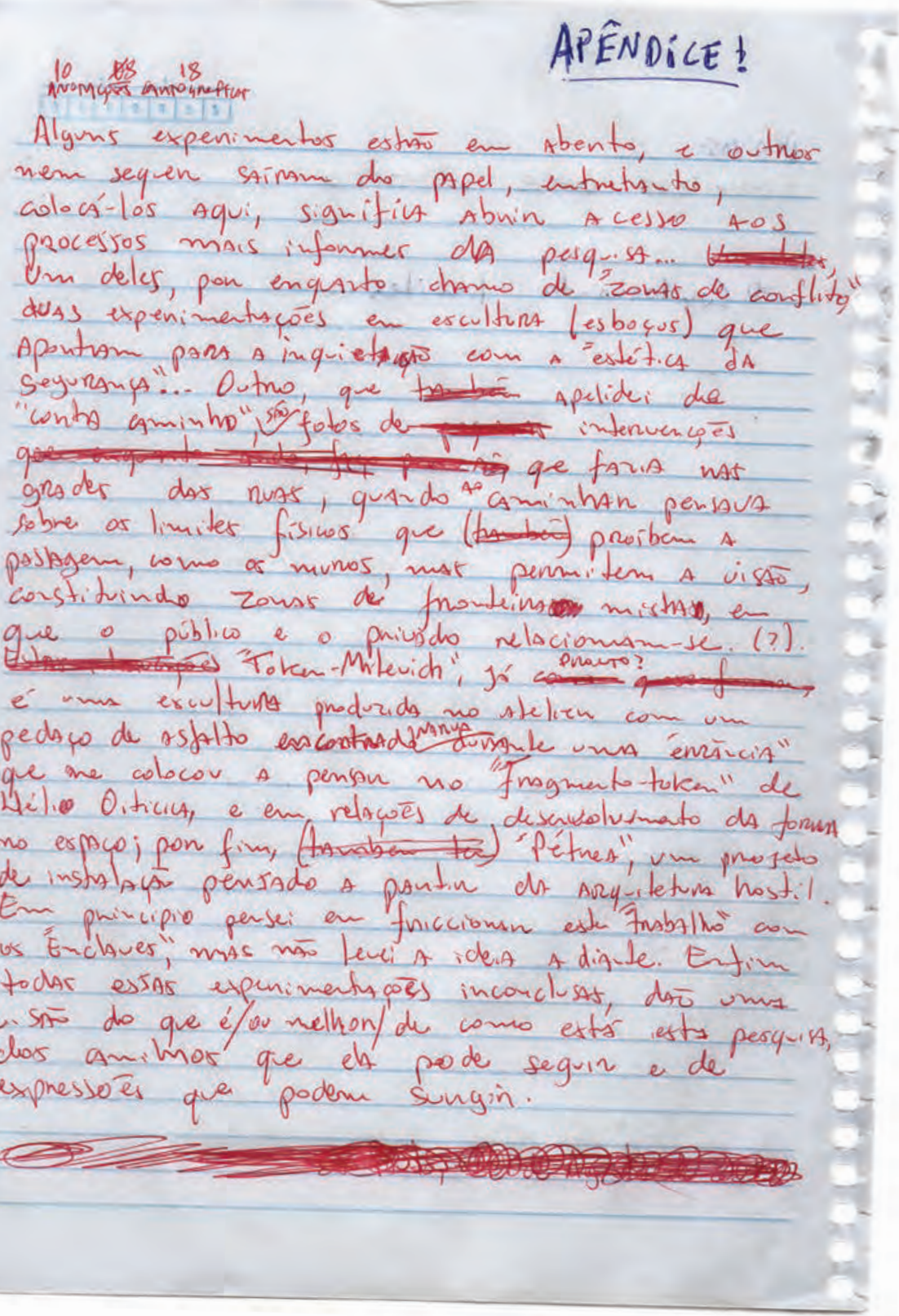




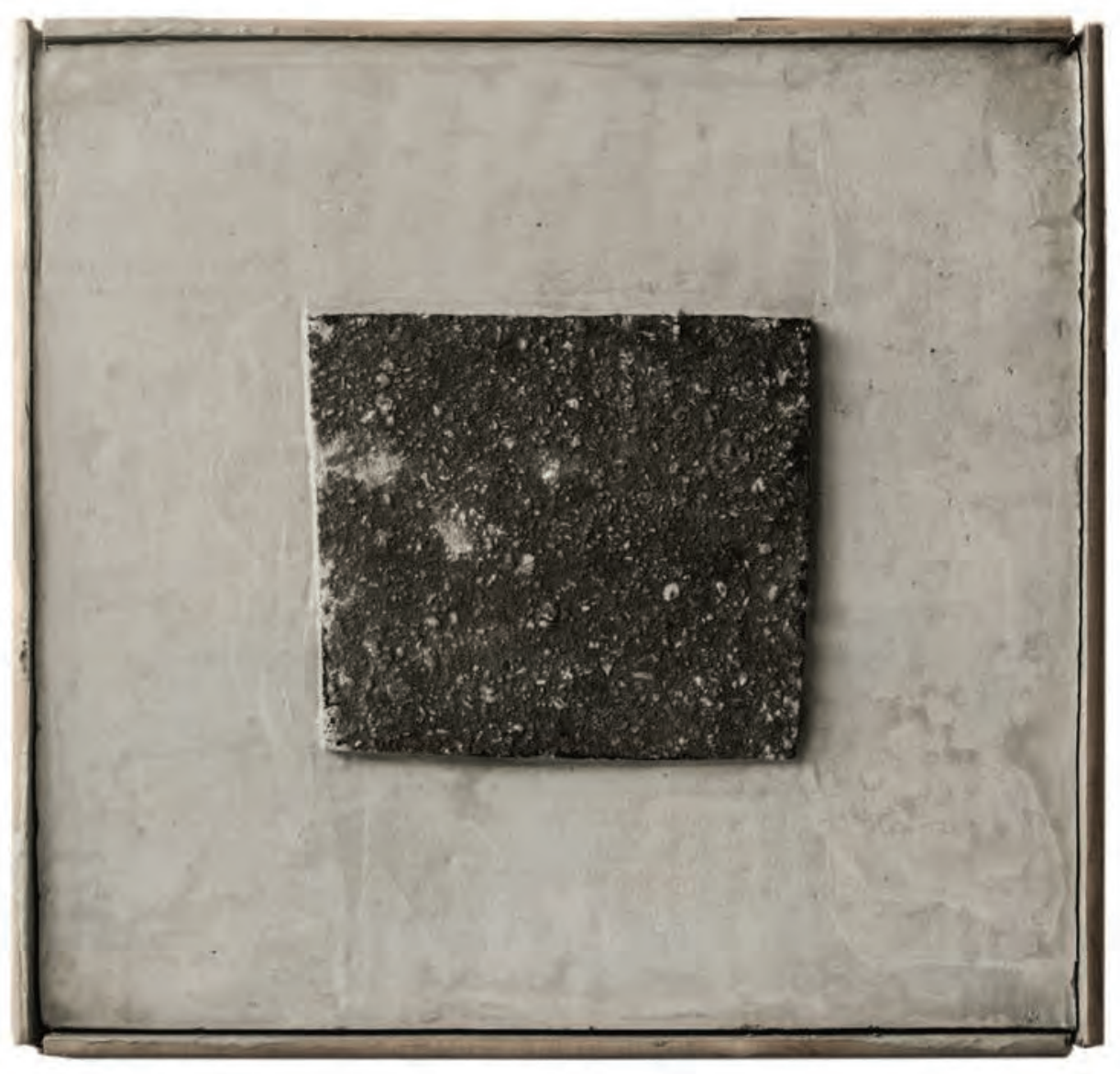



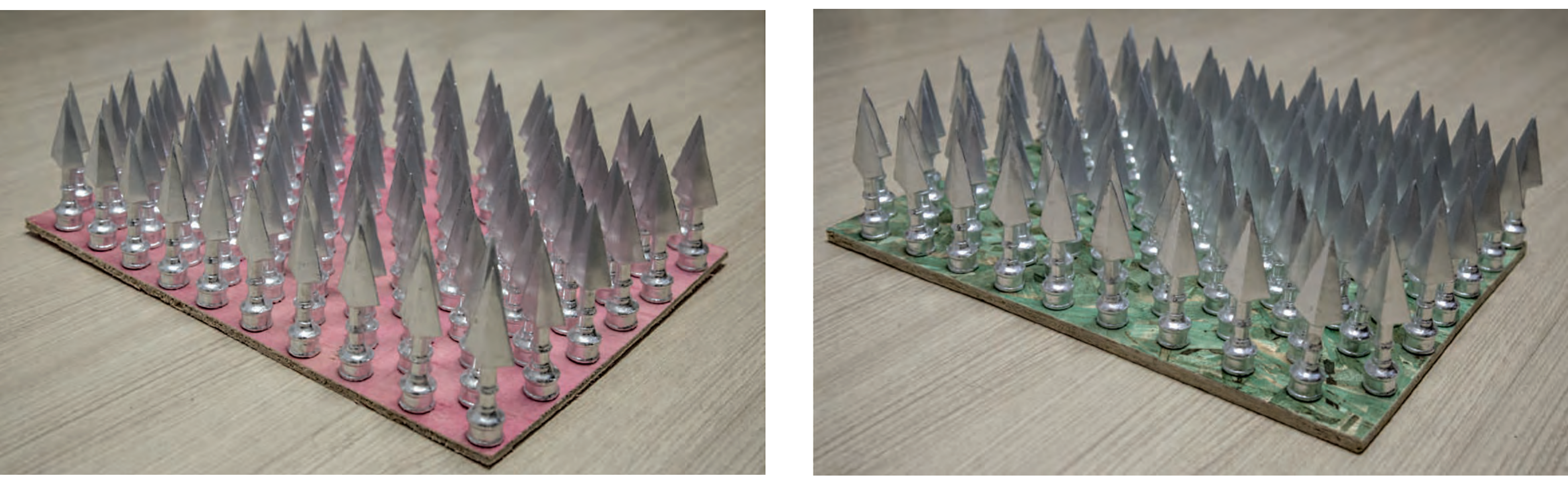

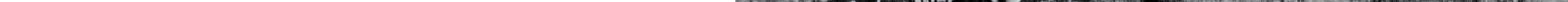


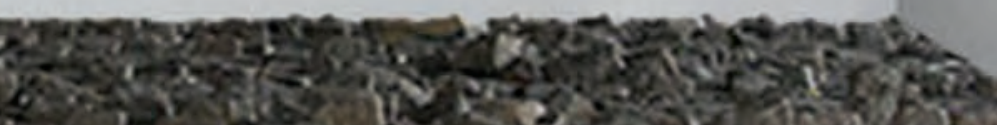


0 presente trabalho foi realizado com apoio da Coordenação de Aperfeiçoamento de Pessoal de Nível Superior - Brasil (CAPES) - Código de Financiamento 001 


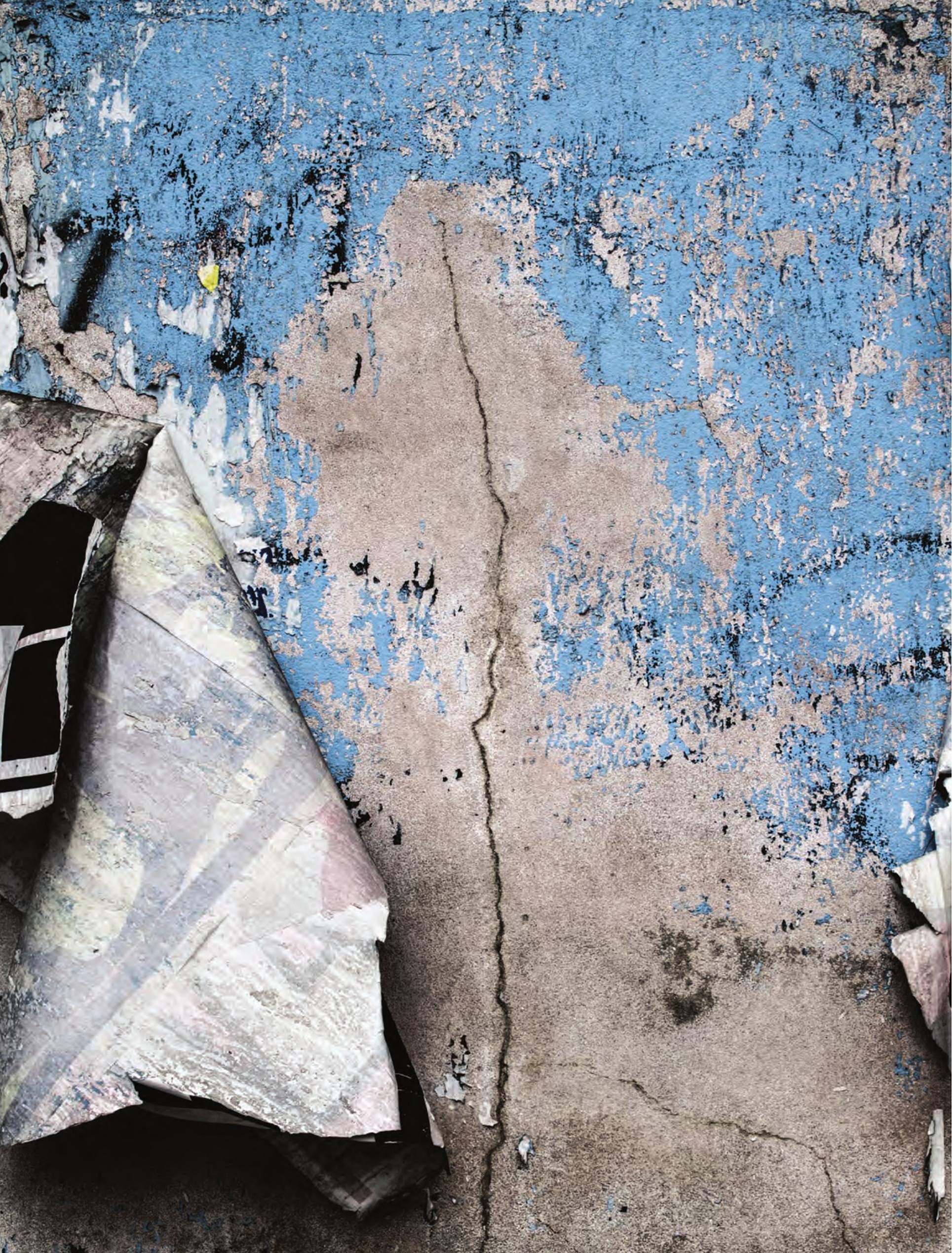

